\title{
AVALIAÇÃO DA EFICÁCIA DE PLACAS ESTABILIZADORAS COM PADRÃO DE GUIA BALANCEADA BILATERAL NO CONTROLE DOS DESARRANJOS INTERNOS DA ATM
}

\section{CARLOS NEANES SANTOS}

Tese apresentada à Faculdade de Odontologia de Bauru, da Universidade de São Paulo, como parte dos requisitos para a obtenção do título de Doutor em Odontologia, área de Reabilitação Oral.

\section{BAURU}

2003 


\section{AVALIAÇÃO DA EFICÁCIA DE PLACAS ESTABILIZADORAS COM PADRÃO DE GUIA BALANCEADA BILATERAL NO CONTROLE DOS DESARRANJOS INTERNOS DA ATM}

\section{CARLOS NEANES SANTOS}

Tese apresentada à Faculdade de Odontologia de Bauru, da Universidade de São Paulo, como parte dos requisitos para a obtenção do título de Doutor em Odontologia, área de Reabilitação Oral

Orientador: Prof. Dr. Paulo César Rodrigues Conti 


\section{Santos, Carlos Neanes
Sa59a Avaliação da eficácia de placas estabilizadoras com padrão de guia balanceada bilateral no controle dos desarranjos internos da ATM / Carlos Neanes Santos. -- Bauru, 2003. \\ xxxii, 261 p. : il. ; $30 \mathrm{~cm}$. \\ Tese. (Doutorado) -- Faculdade de \\ Odontologia de Bauru. Universidade de São Paulo. \\ Orientador: Prof. Dr. Paulo César Rodrigues Conti}

Autorizo, exclusivamente para fins acadêmicos e científicos, a reprodução total ou parcial desta dissertação/tese, por processos fotocopiadores e outros meios eletrônicos.

Assinatura:

Data:

Comitê de Ética da FOB: Projeto de pesquisa aprovado em 28 de junho de 2002

No do Protocolo: Processo No 27/2002 


\section{CARLOS NEANES SANTOS}

29 de junho de 1962

$1987-1988$

$1987-1988$

$1997-2000$

Associações
Nascimento

Aracaju - SE

Curso de Especialização em

Prótese Dental, na Faculdade de

Odontologia de Bauru,

Universidade de São Paulo.

Curso de Aperfeiçoamento em

Periodontia, pela PROFIS -

Sociedade de Promoção Social do

Fissurado Lábio-Palatal, Bauru -

SP.

Professor do Departamento de Prótese do Curso de Odontologia da Universidade Federal de Sergipe

Curso de Pós-Graduação em Odontologia, área de Reabilitação Oral - Prótese, em nivel de Mestrado, na Faculdade de Odontologia de Bauru, da Universidade de São Paulo.

Associação Brasileira de Odontologia - Secção de Sergipe 


\section{À Deus,}

por que sem a Sua permissão, nada seria possivel. 


\section{Ao meu pai (in memoriam)}

Hoje, o senhor já não está mais aqui entre nós.

Entretanto, nada teria acontecido se não fosse a sua existência.

Recebi de sua pessoa exemplos que regem e regerão minha vida para sempre.

Se a saudade é muita, e muitas vezes o vazio palpável nos faz sofrer, sempre ficará a lembrança boa de tantos momentos inesqueciveis.

Este é um deles. Em pensamento, sua presença é concreta e compartilha comigo a alegria de mais uma etapa vencida em minha vida.

E aqui você também está mais do que presente: sua fé, caráter e perseverança são valores, para mim, inesqueciveis, o bem maior que um filho pode herdar de seu pai. E isso tudo, pai, você deixou para mim.

Se hoje a minha vida se enriquece e se abre à ciência, a sua lembrança será a mola propulsora para que eu não perca o entusiasmo na busca do saber.

Meu eterno agradecimento por tudo o que fez e ainda continuará fazendo, não só para mim, mas para minhas filhas, a quem seus ensinamentos serão transmitidos.

A você, pai, meu eterno agradecimento e todo o meu amor. 
À minha mãe, maravilhosa como ela é, pelo amor, apoio e dedicação constantes, durante minha vida, sobretudo por terem me ensinado que a fé é o fundamento de nossa existência.

\title{
À meus irmãos, Osmax, Jeane, Osman, Osmário, Ivana, Osanan, Grece, Márcio, pelo estímulo e compartilhamento de minhas aspirações, em especial a Jeane e Osman, por terem me dado a satisfação de poder chegar ao ideal sonhado.
}

\begin{abstract}
À Alaide Herminia, amiga, companheira e mulher, pelo incentivo e pela força na elaboração desta tese, e ainda, pela maneira carinhosa e compreensiva com que sempre me apoiou.
\end{abstract}

Às minhas filhas, Vanessa e Maria, onde encontro, na alegria de seus sorrisos, a razão maior na busca de meus ideais, e que, apesar de estarem ausentes, me deram forças para continuar essa longa jornada, e se isto que sinto por elas não for amor lindo, puro $e$ verdadeiro, eu sinceramente não sei o que é amar.

De todo o coração, dedico este trabalho 
Ao meu orientador, Prof. Dr. Paulo César Rodrigues Conti, que devo agradecer, não só pela orientação no trabalho, mas também pela amizade, pela compreensão nos momentos em que o fator tempo estava contra o nosso cronograma e, acima de tudo, pela confiança em mim depositada no momento em que aceitou ser o meu orientador.

Meu sincero agradecimento pela orientação, mais uma vez, precisa, experiente, sincera e amiga durante a elaboração deste trabalho. 
Aos professores da Universidade Federal de Sergipe, que com a paciência e dedicação dos primeiros mestres, motivaram a minha opção à especialidade;

Ao Prof. Dr. José Valdes Conti, Prof. Dr. Milton Salvador, Prof. Dr. Waldyr Janson e Prof. Dr. Euloir Passanezi, que sempre estiveram presentes, desde o inicio do $1^{\circ}$ curso de especialização, a quem sempre sou grato pelo que me ensinaram;

a minha admiração e gratidão. 
Ao Prof. Dr. Luis Fernando Pegoraro, um exemplo de profissional, que, através de seus múltiplos conhecimentos clinicos e cientificos, contribuiu, e muito, para eu ser o profissional que sou hoje,

meu reconhecimento e gratidão.

Ao Prof. Dr. Gerson Bonfante, mestre e pesquisador incansável, expressão da odontologia brasileira, e marco de exemplo e orgulho da prótese presente e do futuro,

meu agradecimento.

Aos Professores do Departamento de Prótese da Faculdade de Odontologia de Bauru: Dr. Accácio Lins do Valle, Dr. Wellington Bonachela, Dr. José Henrique Rubo, e Dr. ${ }^{a}$ Lucimar Vieira, Renato de Freitas, Vinicius Porto,

pela amizade e cordialidade que sempre me dispensaram, e por tudo o que me ensinaram, contribuindo em muito para o meu aprimoramento profissional, O meu muito obrigado. 
Ao anônimo paciente, pois sem a sua colaboração seria impossivel ter realizado este trabalho. Agradeço e reconheço a sua importância no processo do caminhar da ciência. 
Aos colegas e amigos do Curso de Mestrado:

Vagner Ortega, Andréa, Leticia, Sérgio, Daniela, Vinicius Janson, Murilo, Mário, Paulo, Raquel, Renato, Leila, Jeferson, Estela, Mauro, Luciana, Lula, Tatiane, Osvaldo $e$ Mariana

pela alegria compartilhada e pela amizade.

Aos colegas e amigos do Curso de Doutorado:

Nelsinho, Barnabé, Juliano, Stefania, Rudys, Vinicius, Gildo, João Evandro, Luciano, Henrique, Materson, Sérgio, Daniel, Luis Ramos pelo carinho, pela troca de conhecimento, pela experiência adquirida, pelo agradável convívio nestes anos.

Á todos os colegas e amigos: Mikaela, Tânia, Melissa, Estevan, Samara com os quais pude compartilhar carinho e amizade.

A todos os funcionários do Departamento de Prótese da FOB-USP: Edna, Débora, Reivanildo, Marcelo, Geraldo e Didi, por toda atenção, gentiliza e carinho a mim dispensados durante estes anos... 


\section{AGRADECIMENTOS ESPECIAIS}

A minha amiga Rosa...

bem, a essa minha amiga não tenho palavras para

expressar, mas vou tentar: Obrigado pelo apoio, estimulo, compreensão e por tantas outras coisas que às vezes só apenas bons amigos podem fazer por nós. Portanto, mais uma vez, obrigado.

Às minhas amigas Silvana, Fernanda, Graziela $e$ Viviane pelo apoio, Linda, Patricia, Fernanda pelo apoio, incentivo e bons momentos em passamos juntos.

Aos amigos Mikaela, Renato e Rafael, pela colaboração dada neste trabalho.

Aos meus sobrinhos, em especial a Roberta Tunes, pela ternura, graciosidade com que sempre se apresenta.

Aos amigos sempre amigos, Luciano Brandão, Augusto César, Jório da Escóssia, André Lucas, pelo carinho de irmão a mim dispensado. 
Aos amigos e companheiros de trabalho, Luis Carlos, Pacheco, Anuska, Patricia, Hermenegildo, Edvaldo, Ivana, Marta, Selma, Marabeau, Maira, Maria Helena, cuja amizade e apoio me fizeram seguir em frente.

À minha sogra (in memorian), ao meu sogro, às minhas cunhadas e cunhados, pelo apoio e pelo incentivo durante esta dificil jornada, minha gratidão e meu amor.

Ao Des. José Barreto Prado, a quem dispenso afeição e carinho paternos. 


\section{À Prof ${ }^{a}$ Dr $^{a}$ Ana Lúcia Álvares Capelozza,}

exemplo de dignidade, pela amizade, incentivo $e$ colaboração que sempre obtive.

Ao Prof. Dr. Carlos Araújo, pelos ensinamentos científicos, oferecendo sempre excelentes sugestões, para o desenvolvimento do trabalho, confirmando seu grande conhecimento cientifico.

Aos professores das disciplinas de Dentistica e Materiais Dentários pela atenção e tratamento gentil e amigo que sempre dispensaram a mim.

Ao Prof. Francisco Alencar pela atenção dispensada ao aceitar o convite para participar de minha banca examinadora.

Ao amigo e colega João Evandro, pelo apoio, pela amizade, pela transmissão de conhecimentos e pela presteza, que sempre teve comigo durante esses anos de convivência na mesma disciplina-DTM. Obrigado por ter vindo de tão longe e participar desta banca. 


\section{AGRADEÇO AINDA}

À Faculdade de Odontologia de Bauru, da Universidade de São Paulo, por meio de sua Diretora, Prof. ${ }^{\boldsymbol{a}}$ Dr. ${ }^{\boldsymbol{a}}$ Maria Fidela de Lima Navarro e Vice-Diretor, Prof. Dr. Luiz Fernando Pegoraro, por me acolherem nos cursos de Mestrado e Doutorado, o que foi fundamental para o aprimoramento dos meus conhecimentos;

Ao Presidente da Comissão de Pós-Graduação da FOB, Prof. Dr. José Carlos Pereira, pela seriedade e firmeza com que vem desenvolvendo seu trabalho;

\section{À Faculdade de Odontologia da Universidade Federal de}

Sergipe, que concedeu afastamento de minha atividades profissionais e os recursos necessários a participação no curso;

Ao Serviço de Triagem da Faculdade de Odontologia de Bauru, USP, representado por essa pessoa amiga, Leucy, ao proporcionar a condição para seleção dos pacientes, passo fundamental para a parte experimental da pesquisa. 
Aos funcionários da Pós-Graduação pela dedicação, amizade e eficiência.

Ao Prof. José Roberto Lauris, pela ajuda na estatística e à Prof. ${ }^{\boldsymbol{a}}$ Eloisa pela leitura e pelas correções suplementares deste trabalho.

Agradeço também, a Leila, Paulo, Tiago e Gisele, pelo apoio técnico na execução deste trabalho.

Aos funcionários da biblioteca e reprografia, pelo solicitude com que sempre me receberam.

Às amigas Fátima e Maristela pela dedicação e empenho com que realizaram a estrutura deste trabalho.

À Coordenação do CNPq, pelos recursos proporcionados a minha freqüência ao curso de Pós-Graduação. 
À todos meus professores do Curso de Graduação da Faculdade de Odontologia da Universidade Federal de Sergipe, que certamente, em muito contribuíram para a minha formação profissional.

À Universidade Federal de Sergipe, na pessoa do Magnifico Reitor Prof. Dr. José Fernandes de Lima.

À Coordenadora de Assuntos Internacionais e Capacitação Docente e Técnica, Prof. ${ }^{a}$ Andréia.

Aos colegas da Associação Brasileira de Odontologia - Secção de Sergipe, representado pelo seu presidente Manuel Barreto

Ao Conselho Federal de Odontologia - Seçcão de Sergipe, representado pelo seu presidente Tadeu Augusto.

À Diretora da EAP, Maria Marta Virginia.

À todos os funcionários da Faculdade de Odontologia de Bauru, da Universidade de São Paulo, que com boa vontade e dedicação, atendem com gentileza às nossas solicitações.

Aos funcionários do Instituto de Ensino Odontológico, Edson, Mariluci, Daniela, Renata, Rosana e D. Tereza, pela dedicação e respeito. 
À todos amigos que, direta ou indiretamente, contribuíram para a realização desta conquista.

O meu muito obrigado! 
Sumário 


\section{SUMÁRIO}

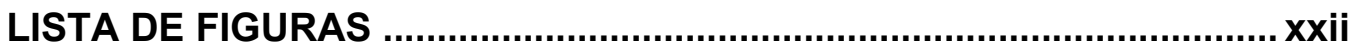

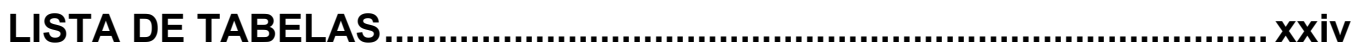

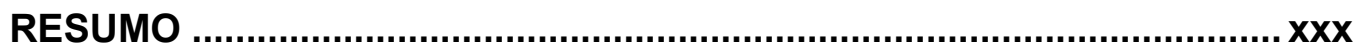

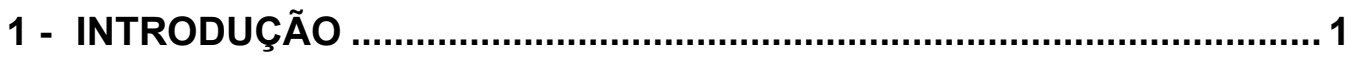

2 - REVISÃO DE LITERATURA

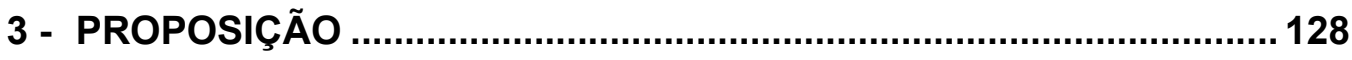

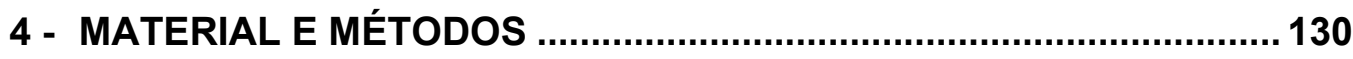

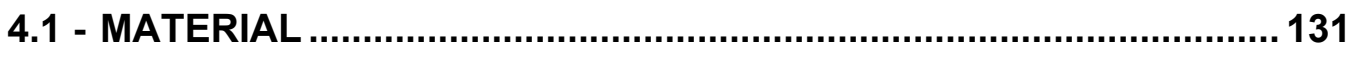

4.2 - MÉTODO

5 - RESULTADOS

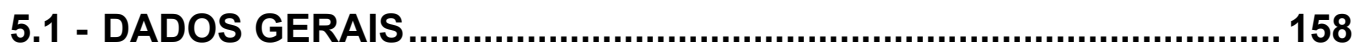

5.2 - ESCALA DE ANÁLISE VISUAL DE DOR ………….......................... 159

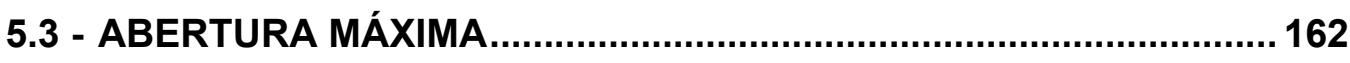

5.4 - MOVIMENTOS EXCURSIVOS DA MANDÍBULA ................................ 163

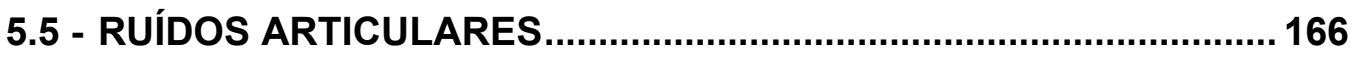

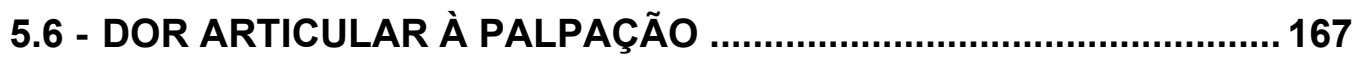

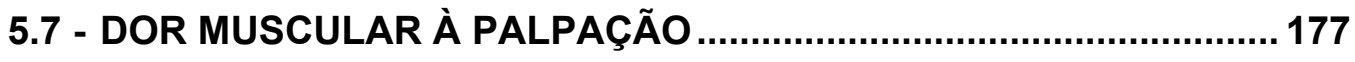

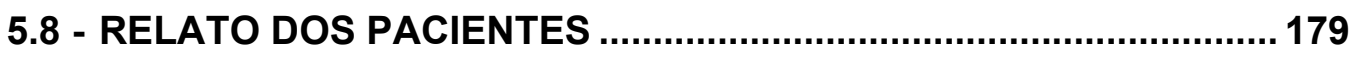




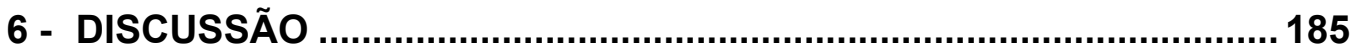

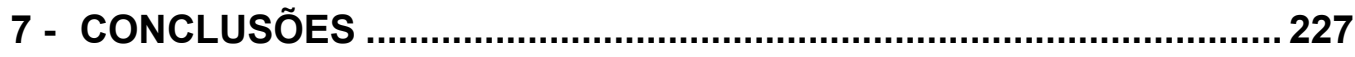

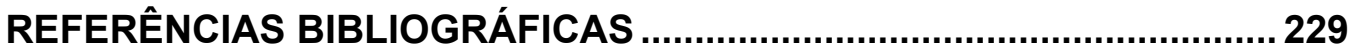

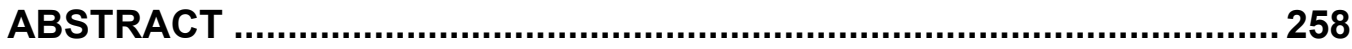

APÊNDICE 
Lista de Figuras 


\section{LISTA DE FIGURAS}

FIGURA 1 - Placa estabilizadora do grupo I

FIGURA 2 - Placa estabilizadora do grupo II 132

FIGURA 3 - Placa não-oclusiva do grupo III 133

FIGURA 4 - Ajuste oclusal. 142

FIGURA 5 - Variação dos valores da EAV (mm) nos diferentes grupos ao longo do tempo 160

FIGURA 6 - Variação da abertura bucal (em mm) nos diferentes grupos, ao longo do tempo 163

FIGURA 7 - Variação dos valores de dor à palpação no aspecto lateral da ATM direita, ao longo do tempo 169

FIGURA 8 - Variação dos valores de dor à palpação no aspecto lateral da ATM esquerda, ao ongo do tempo 172

FIGURA 9 - Valores dos valores de dor à palpação no aspecto posterior da ATM direita, ao longo do tempo 175

FIGURA 10 - Valores de dor à palpação no aspecto posterior da ATM esquerda, ao longo das avaliações 
Lista de Tabelas 


\section{LISTA DE TABELAS}

TABELA 1 - Média de distribuição da idade entre os grupos e o respectivo desvio padrão 158

TABELA 2 - Distribuição da amostra entre os grupos de acordo com o gênero 158

TABELA 3 - Distribuição das médias dos valores de EAV nos diferentes períodos de mensuração dos grupos (em mm) 159

TABELA 4 - Comparações individuais (MANOVA - Tukey) dos resultados obtidos dos valores de EAV, para o grupo I (placa balanceada) 160

TABELA 5 - Comparações individuais (MANOVA - Tukey) dos resultados obtidos dos valores de EAV, para o grupo II (placa com guia). 161

TABELA 6 - Comparações individuais (MANOVA - Tukey) dos resultados obtidos dos valores de EAV, para o grupo III (placebo) ...... 161

TABELA 7 - Avaliação inter-grupos da alteração total na EAV, após todos os períodos de mensuração, nos 3 grupos (MANOVA Tukey) 162 
TABELA 8 - Distribuição da média de abertura (em $\mathrm{mm}$ ) entre os grupos nos diferentes períodos de mensuração

162

TABELA 9 - Distribuição média dos valores de lateralidade direita (em milímetros) entre os grupos nos diferentes períodos de mensuração. 164

TABELA 10 - Avaliação inter-grupos da variação total na lateralidade direita, após todos os períodos de mensuração, nos 3 grupos (MANOVA - Tukey) 164

TABELA 11 - Distribuição média dos valores de lateralidade esquerda (em milímetros) entre os grupos nos diferentes períodos de mensuração 165

TABELA 12- Distribuição média dos valores do movimento protrusivo (em milímetros) entre os grupos nos diferentes períodos de mensuração 165

TABELA 13 - Valores absolutos e percentuais de indivíduos com ruídos articulares, em cada grupo, durante as avaliações 166

TABELA 14 - Valores dos escores médios de dor à palpação do aspecto lateral da ATM direita e sua variação ao longo das avaliações (Friedman - Student-Newman-Keuls) para o grupo I (placa balanceada) 168 
TABELA 15 - Valores dos escores médios de dor à palpação do aspecto lateral da ATM direita e sua variação ao longo das avaliações (Friedman - Student-Newman-Keuls) para o grupo II (placa com guia). 168

TABELA 16 - Valores dos escores médios de dor à palpação do aspecto lateral da ATM direita e sua variação ao longo das avaliações (Friedman - Student-Newman-Keuls) para o grupo III (placebo) 169

TABELA 17 - Valores dos escores médios de dor à palpação do aspecto lateral da ATM esquerda e sua variação ao longo das avaliações (Friedman - Student-Newman-Keuls) para o grupo I (placa balanceada) 170

TABELA 18 - Valores dos escores médios de dor à palpação do aspecto lateral da ATM esquerda e sua variação ao longo das avaliações (Friedman - Student-Newman-Keuls) para o grupo II (placa com guia) 171

TABELA 19 - Valores dos escores médios de dor à palpação do aspecto lateral da ATM esquerda e sua variação ao longo das avaliações (Friedman - Student-Newman-Keuls) para o grupo III (placebo) 171

TABELA 20 - Valores dos escores médios de dor à palpação do aspecto posterior da ATM direita e sua variação ao longo das 
avaliações (Friedman - Student-Newman-Keuls) para o grupo I (placa balanceada) .............................................. 173

TABELA 21 - Valores dos escores médios de dor à palpação do aspecto posterior da ATM direita e sua variação ao longo das avaliações (Friedman - Student-Newman-Keuls) para o grupo II (placa com guia) 173

TABELA 22 - Valores dos escores médios de dor à palpação do aspecto posterior da ATM direita e sua variação ao longo das avaliações (Friedman - Student-Newman-Keuls) para o grupo III (placebo). 174

TABELA 23 - Valores dos escores médios de dor à palpação do aspecto posterior da ATM esquerda e sua variação ao longo das avaliações (Friedman - Student-Newman-Keuls) para o grupo I (placa balanceada) 175

TABELA 24 - Valores dos escores médios de dor à palpação do aspecto posterior da ATM esquerda e sua variação ao longo das avaliações (Friedman - Student-Newman-Keuls) para o grupo II (placa com guia) 176

TABELA 25 - Valores dos escores médios de dor à palpação do aspecto posterior da ATM esquerda e sua variação ao longo das avaliações (Friedman - Student-Newman-Keuls) para o grupo III (placebo). 176 
TABELA 26 - Valores de "p" (Kruskal-Wallis) da avaliação das médias de variação nos escores de dor à palpação muscular. 178

TABELA 27 - Distribuição das médias dos valores de dor à palpação na porção anterior do músculo temporal esquerdo 178

TABELA 28 - Distribuição das médias dos valores de dor à palpação do corpo do músculo masseter esquerdo 179

TABELA 29 - Valores absolutos e percentuais de relato quanto à alteração de ruídos nos diferentes períodos de mensuração 181

TABELA 30 - Valores absolutos e percentuais de relato quanto à alteração oclusal nos diferentes períodos de mensuração 183

TABELA 31 - Valores absolutos e percentuais de relato quanto ao conforto nos diferentes períodos de mensuração 184 
Resumo 


\section{RESUMO}

O objetivo deste estudo foi avaliar o efeito de placas estabilizadoras com guia balanceada bilateral, placas com guia pelo canino e placa não oclusiva. Para tal, utilizou-se uma amostra de 57 indivíduos, portadores de sinais e sintomas de deslocamento do disco com redução, com queixa de dor na ATM e sensibilidade à palpação na mesma, em pelo menos um dos lados os quais foram aleatoriamente distribuídos em três grupos: $1^{\circ}$ grupo: composto por 19 indivíduos que receberam, como forma de tratamento, uma placa estabilizadora modificada, cujo desenho permita que durante os movimento excursivos houvesse sempre contato simultâneo de parte dos dentes em todos os segmentos da placa. $2^{\circ}$ grupo: composto por 20 indivíduos que receberam como forma de tratamento uma placa estabilizadora convencional com guia pelo canino que estabelecia desoclusão de todos os outros dentes nos movimentos excursivos. $3^{\circ}$ grupo: composto por 18 indivíduos que receberam uma placa não oclusiva cujo desenho não interferia com a oclusão. Toda a amostra foi acompanhada durante 6 meses, sendo avaliada através da escala de análise visual (EAV); palpação da ATM, dos músculos elevadores da mandíbula, análise dos movimentos da mandíbula e ruído articular. Uma avaliação do relato do paciente em relação ao ruído articular, alteração da oclusão e conforto também foi feita. Os resultados demonstraram que o tipo de guia não influenciou o comportamento de redução da dor, porém ambas as placas oclusais foram superiores à não-oclusiva em relação à escala de dor. E que, 
estatisticamente, apesar da obtenção de resultados semelhantes com relação aos movimentos de abertura, lateralidade esquerda, protrusivo, dor articular à palpação e na dor à palpação da maioria dos músculos analisados, nesse experimento, as placas com guia balanceada (grupo I) e as com guia pelo canino tiveram melhores resultados clínicos, nesses itens analisados. Com relação ao relato dos indivíduos para o conforto com a placa e ruído articular, houve uma melhor associação para o grupo I e II. Baseados no acima exposto, conclui-se que não há diferença entre a guia balanceada e a guia pelo canino no tratamento de indivíduos com deslocamento do disco com redução. 
Introdução 


\section{1 - INTRODUÇÃO}

Placas oclusais são amplamente utilizadas no tratamento das Disfunções Temporomandibulares (DTM) para alterar as relações oclusais e redistribuir as forças, evitar o desgaste dos dentes, alterar as relações estruturais entre as forças e as ATMs, melhorar a função muscular e articular e aliviar a dor associada (WIDMALM $\left.{ }^{182}, 1999\right)$, além de proteger o dente e o periodonto de danos contra forças potenciais induzidas pelo bruxismo. Entretanto, sabe-se pouco dos mecanismos de ação desses aparelhos.

Muitos estudos descreveram os efeitos do tratamento das placas oclusais sobre os sinais e sintomas das DTMs $^{5,8,28,29,43,44,48,49,58,66,67,92,96,103,113, ~ 133, ~ 142, ~ 146, ~ 154, ~ 177, ~ 178, ~ 183, ~ 185, ~} 191$.

Outros observaram a relação entre as placas oclusais e o apertamento noturno $^{42,46,75,76,142,148,149,162,193}$. Outros examinaram os efeitos das placas oclusais sobre a atividade eletromiográfica dos músculos elevadores da mandíbula 2 24, 32, 37, 61, 62, 76, 99, 110, 120,127, 161, 164, 179, 186, 190 . Enfim, realizaramse inúmeros estudos com o propósito de identificar como a placa realmente atua no processo de melhora dos sinais e sintomas dessas disfunções.

Várias teorias têm sido propostas para explicar a aparente efetividade dos diversos desenhos desses aparelhos: teoria do desengajamento oclusal, da alteração da dimensão vertical de oclusão (DVO), do realinhamento músculo-mandibular, do reposicionamento da 
ATM, da conscientização, efeito placebo $^{35,42}$, etc. Mas nenhum deles foi ainda cientificamente comprovado, talvez por falta de estudos que não seguiram alguns dos procedimentos considerados essenciais para um controle clínico, como a presença de um grupo controle, métodos de registros padronizados, aleatoriedade da amostra, tamanho da amostra, dados coletados e análise com mascaramento duplo etc. Qualquer que seja o mecanismo de ação proposto, é comumente assumido que placas oclusais têm um valor real de terapêutica no tratamento das DTM. Essa crença é baseada em numerosos relatórios comuns, com um alto índice de sucesso clínico encontrado somente com o uso de placas ou destas combinadas com outras modalidades.

No tratamento das DTMs, uma placa de cobertura oclusal total é a modalidade mais amplamente usada, com grande sucesso clínico $^{5,8,28,29,43,44,48,49,58,66,67,92, ~ 96, ~ 103, ~ 113, ~ 133, ~ 142, ~ 146, ~ 154, ~ p e l o s ~ d e n t i s t a s . ~}$

Esses aparelhos fornecem ao profissional uma forma não invasiva e reversível de intervenção para o tratamento das DTMs.

Uma pesquisa envolvendo 10.000 membros da Associação Dentária Americana revelou que a terapia com placa oclusal foi a modalidade de tratamento mais realizada (68\%) nos pacientes com dor e disfunção miofascial e que, dos entrevistados, $65 \%$ dos clínicos gerais e 44\% dos especialistas na área, preferem a placa estabilizadora com guia pelo canino e $23 \%$ dos clínicos e $25 \%$ dos especialistas preferem a mesma placa, só que utilizando a função em grupo ${ }^{57}$. 
Portanto, um dos desenhos mais utilizados no tratamento das DTMs é a placa lisa de mordida ou placa estabilizadora, que geralmente é fabricada para a arcada superior, cobrindo todos os dentes e proporcionando o relacionamento oclusal satisfatório. Apesar das elevadas taxas de sucesso clínico na terapia com placas de estabilização na redução dos sinais e sintomas de DTM serem relatadas, pouco é conhecido a respeito de como esses dispositivos oclusais podem causar melhora e ainda, qual o real valor da incorporação das guias (confeccionadas sobre as placas) sobre os vários sintomas que acometem a ATM.

Além disso, investigações mais recentes, e também contraditórias, falam da carga na articulação temporomandibular $6,11,12,13,17,22,31,51,55,72,80,81,85,87,88,91,97,108,119,124,129,130$, 136, 153, 170, 176, 181, 190 ou pressão empregada dentro da fossa glenóide pelos diferentes tipos de placa $91,97,130,143,153,190$ e que talvez a confecção de uma placa estabelecendo uma guia apropriada pudesse acelerar o processo de cicatrização dos componentes da articulação e, conseqüentemente, promover um processo de cura mais rápido nos pacientes com DTM. Isso porque a carga poderia ser um importante fator na função e estabilidade da articulação temporomandibular, já que perfurações, necroses, deslocamento de disco, remodelação do osso temporal e dores na articulação podem ser resultado de cargas excessivas ou mal dirigidas.

Assim, os efeitos de tratamento das placas de estabilização não são ainda totalmente compreendidas, principalmente em relação ao seu 
modelo. Não há consenso sobre o mecanismo de ação a respeito do melhor desenho para obtenção de melhores resultados clínicos. A falta de estudos clínicos comparativos demonstrando a superioridade de qualquer desenho de placa sobre outro é de preocupação para o clínico que procura oferecer um tratamento mais eficaz para os pacientes.

Esse é um problema crítico, porque o tratamento com placa permanece o procedimento mais comumente utilizado.

È essencial que iniciemos a compreensão do mecanismo de ação dos aparelhos, de tal forma que seus efeitos terapêuticos possam ser melhorados. Portanto, propusemo-nos a investigar o efeito da placa estabilizadora promovendo dois tipos de guias oclusais diferentes: por meio de contato dos caninos maxilar e mandibular durante os movimentos laterais, e dos anteriores durante o movimento protrusivo, de maneira a promover a desoclusão dos dentes posteriores; e por meio do contato simultâneo de parte dos dentes posteriores e anteriores, durante os movimentos excursivos, promovendo uma oclusão balanceada, de maneira a não permitir a desoclusão dos dentes posteriores. 
Revisão de Literatura 


\section{2 - REVISÃO DE LITERATURA}

Os efeitos de uma oclusão natural bilateralmente balanceada no sistema estomatognático foram observados por $\mathrm{HOUSE}^{79}$, em 1931. Ele verificou que o contato oclusal sobre as superfícies dos dentes, em todas as excursões promoveu a um desgaste mais rápido do esmalte dentário.

Apesar de os contatos da oclusão balanceada terem sido essenciais para a estabilidade das próteses totais, SCHUYLER ${ }^{157}$, em 1935, observou que os mesmos foram traumáticos para a dentição natural, podendo causar disfunção da ATM, envolvimento periodontal ou desgaste excessivo.

Segundo ROBINSON ${ }^{147}$, em 1946, a anatomia e histologia indicam que as articulações temporomandibulares não são áreas para suportar estresse e que a mandíbula não pode ser considerada uma alavanca de classe III porque os músculos da mastigação são posicionados de tal forma que a força resultante de suas ações pode ser suportada pelos dentes,estando assim as articulações livres de estresse traumatizante. Além disso, ainda de acordo com o autor, o disco não é composto de fibrocartilagem (reconhecida como não sendo reparável), mas de um tecido conjuntivo especializado que é capaz de reparo. 
D’AMICO ${ }^{41}$, em 1958, afirma que quando os caninos estão intercuspidados e ocorrem movimentos laterais e para frente, há uma interrupção imediata na tensão dos músculos temporal e masseter reduzindo, assim, a magnitude da força oclusal. Segundo o autor, não importa quanto o indivíduo tente tensionar esses músculos pois, enquanto os caninos estiverem em contato, é impossível para os mesmos assumirem tensão total. Segundo o autor, o comprimento da raiz do canino e a estrutura anatômica do processo alveolar dá suporte da intenção de natureza quanto à função pretendida.

A capacidade da oclusão balanceada em manter a estabilidade da dentição foi considerada desapontadora para STUART ${ }^{174}$; STALLARD, em 1960. Tão logo as restaurações sejam colocadas, pequenas facetas de desgaste aparecem, cristas são destruídas e cúspides erosionadas. Eles verificaram, também, que pela mudança do contato interoclusal dos dentes posteriores para os dentes anteriores, nos movimentos excursivos, a alavanca na mandíbula seria mínima, estabelecendo, assim, uma melhor proteção aos dentes posteriores pelos dentes anteriores e que, na máxima intercuspidação, a proteção dos anteriores era exercida pelos posteriores.

SCHUYLER ${ }^{158}$, em 1963, observou que os contatos de balanceio nos dentes posteriores, nos movimentos funcionais bilaterais ou protrusivos, podem ser desejáveis ou essenciais para a estabilidade de próteses totais, mas não o são para a estabilidade de dentições naturais. 
Segundo o autor, esses contatos são decididamente traumatogênicos, contribuindo para a patologia das ATMs e dos dentes envolvidos. O autor relatou, também que uma guia anterior desfavorável tende a produzir movimentos funcionais anormais nos côndilos, contribuindo para determinadas patologias.

Os efeitos da placa de resina acrílica rígida, placa resiliente e placa de Hawley modificada em 184 indivíduos com bruxismo e sintomas de ATM, foram avaliados por POSSELT; WOLFF ${ }^{142}$, em 1963. Após 17 a 40 meses de observação, não chegaram a conclusões definitivas em relação a que um tipo tivesse sido melhor que os outros, pois uma alta porcentagem de indivíduos foi curada ou demonstrou melhora. Entretanto, houve uma tendência de melhores resultados quando a placa de resina acrílica rígida foi utilizada.

Com o intuito de correlacionar os contatos dentários em diferentes relações maxilo-mandibulares, em conjunto com registro eletromiográfico, SCHAERER; STALLARD; ZANDER ${ }^{156}$, em 1967, verificaram se haveria inter-relação entre os contatos dentários e a atividade muscular dos músculos mastigatórios pelo uso de radiotransmissores intraorais. Assim, uma interferência em balanceio foi inserida pela alteração no dispositivo do radiotransmissor colocado nas próteses fixas. Então, os registros eletromiográficos dos músculos temporal e masseter foram obtidos simultaneamente aos contatos registrados pelos radiotransmissores. Os autores, então, concluíram que: a) os contatos excêntricos ocorriam tanto no 
final do ciclo mastigatório como em posições excêntricas da mandíbula; b) o número de contatos excêntricos aumentou significativamente se a mastigação fosse realizada com a interferência inserida no lado de nãotrabalho e que o padrão de contração EMG reagiu aos contatos interferentes da mesma maneira que aos outros contatos dentários. Além disso, a interrelação dentro dos grupos musculares, durante o ciclo mastigatório, não foi perturbada.

Analisando as duas teorias de função pelo canino e da oclusão balanceada, ALEXANDER ${ }^{4}$, em 1967, relatou que enquanto na primeira o canino deve suportar as forças de mastigação durante os movimentos excêntricos da mandíbula, na segunda, vários dentes suportam as forças durante os mesmos movimentos. Para o autor, o canino é incapaz de suportar as forças oclusais, pois o mecanismo de proteção existente no ligamento periodontal não funciona. O autor se baseia no fato de que a colocação de uma interferência no canino promoveu perda óssea, presença de bolsa e sintomas de DTM e que, após o estabelecimento de uma oclusão balanceada, observou-se a completa remissão dos sintomas.

Ao examinarem 1200 pessoas jovens, SCAIFE; HOLT ${ }^{155}$, em 1969, observaram que a maior parte dos norte-americanos abaixo de 25 anos de idade tinha guia pelo canino bilateralmente ou unilateralmente. Entretanto foi observado, também, que a maior parte das pessoas acima dos 40 anos de idade tem guia em função em grupo. Os autores sugerem que em muitas pessoas a guia pelo canino é reduzida devido ao desgaste, 
ocorrendo uma transformação gradual para o tipo de oclusão em função em grupo e que uma vez que ambas as oclusões parecem naturalmente com freqüência sendo capazes de manter a livre saúde dentária, cada uma deve ser considerada normal.

BARBENEL ${ }^{11}$, em 1969, fez uma análise das forças na articulação temporomandibular durante a função sob um ângulo predominantemente de engenharia. Para tal objetivo, foi feita uma análise mecânica das forças, fazendo uma abordagem analítica, utilizando as linhas de ação simulada dos músculos mastigatórios e analisando suas interações em relação à articulação e deduzindo as forças resultantes na articulação. Isso apresentou diversos problemas, mas decidiu-se que os parâmetros musculares poderiam ser avaliados pela direção de fibra muscular e da área de origem e inserção dos músculos. Através desses dados foi possível obter um sistema de forças imposta à mandíbula (forças devido à ação muscularforça devido à carga oclusal e força na ATM), durante a mordida. Através de cálculos oriundos dos componentes dessas forças e de dados eletromiográficos dos músculos mastigatórios, foi possível a realização de novas equações matemáticas e, através delas, determinar a magnitude de carga na articulação temporomandibular. Por meio dessas equações, o autor verificou que através de um ajuste experimental, com uma carga nos incisivos, há uma produção de força máxima na articulação; e que com a carga mandibular posicionada mais posteriormente o estresse na articulação deverá ser menor. 
BARBENEL ${ }^{12}$, em 1972, fez uma análise das ações de força na articulação em função da carga oclusal, através de equações obtidas por programação linear, com o objetivo de apenas verificar se a ATM recebe cargas ou não. Para tal, determinou-se primeiramente a linha de ação do músculo da mastigação, e juntamente com a análise do sistema de força, (forças devido a ação muscular, forças devido à carga oclusal e força na articulação temporomandibular) imposto na mandíbula durante o estágio de mordida através de equações matemáticas, chegou-se à conclusão de que a articulação temporomandibular suporta cargas durante a função, e que a verdadeira força articular depende da atividade específica dos músculo da mastigação e da carga oclusal.

LASKIN; GREENE ${ }^{94}$, em 1972, avaliaram a influência da relação doutor-paciente utilizando a terapia placebo em 50 pacientes com síndrome da dor e disfunção miofascial. Cada paciente recebeu uma prescrição de uma droga placebo (Miolax) em conjunto com um endosso entusiástico de seus potenciais efeitos terapêuticos, a qual deveria ser tomada por quatro vezes ao dia, durante uma semana. Para avaliação, as respostas dos pacientes frente ao Miolax foram registradas em um cartão especial desenvolvido pelo centro de pesquisas de ATM. No momento da avaliação de uma semana, os pacientes mostraram grande e ligeira melhora, nenhuma, ou piora de suas condições. Os pacientes que não melhoraram ou pioraram eram levados imediatamente para outras formas de terapia. Então, 26 dos 50 pacientes (52\%) com SDDM relataram alguma melhora em sua condição após a terapia com Miolax. Os autores concluíram: a) que os 
fatores psicológicos desempenham um papel importante no início, curso e remissão dos problemas miofasciais; b) que as respostas potenciais dos pacientes com dor miofascial aos aspectos verbais e não verbais da relação doutor-paciente podem ser usados com vantagem pelos clínicos quando se conduz qualquer tipo de tratamento para os mesmos.

GREENE; LASKIN66, em 1972, verificaram o efeito no tratamento da dor-disfunção miofascial com três tipos diferentes de placas oclusais utilizando 71 indivíduos com sinais e sintomas da síndrome de dordisfunção miofascial. A placa 1, era um aparelho superior sem oclusão e foi considerado um aparelho placebo, pois não estava interposto entre os dentes. Então, todos os indivíduos começaram com uso dessa placa por uma a duas semanas, por 24 horas. Caso as dores melhorassem, eram instruídos a continuarem por mais algumas semanas. As placas daqueles indivíduos que não obtiveram alívio dos sintomas após o período inicial, foram modificados pela adição de uma plataforma adicional que desocluía os dentes posteriores. Se ao final de duas semanas fosse relatada pouca ou nenhuma melhora com o uso dessa placa, placas de resina eram acrescentadas aos lados direito e esquerdo, formando, assim, uma placa estabilizadora. Então, todos os pacientes que fossem melhorando, iam saindo do estudo. Portanto, $87 \%$ dos indivíduos relataram algum grau de melhora em sua condição, com $74 \%$ (52 de 71$)$ se sentindo significativamente melhor. Destes 52, 17 relataram que estavam totalmente melhores. Em relação ao primeiro tratamento, 28 dos 71 indivíduos (40\%) relataram algum grau de melhora, sendo que, apenas 11 deles se sentiram 
bem para interromper o tratamento após as primeiras duas semanas de tratamento.

A mobilidade em 30 quadrantes dos maxilares em indivíduos saudáveis, foi avaliada por O'LEARY; DRAKE ${ }^{135}$, em 1972. Os indivíduos foram divididos em 2 grupos: I) proteção pelo canino e II) proteção por função em grupo. Os autores encontraram que o padrão de mobilidade verificada em cada dente foi maior naqueles que possuíam proteção pelo canino, e que o primeiro pré-molar e molar apresentavam índices de mobilidade, comparados aos outros dentes investigados.

Em 1972, um estudo das forças de mordida em 31 mulheres com síndrome de dor e disfunção e 30 mulheres saudáveis (grupo controle), foi realizado por MOLIN ${ }^{123}$. Para isso, foi utilizado um transdutor de força para medição, o qual foi colocado sobre os dentes, e cujas medidas de dor foram baseadas numa escala de 1 a 5: "1" era dor muito fraca, "2" dor fraca, "3" dor média, "4" dor forte e "5" dor máxima. O autor encontrou diferenças de forças substanciais entre os dois grupos. Essas diferenças aumentaram com os níveis de força e os indivíduos sintomáticos, geralmente, produziram apenas metade a dois terços das forças realizadas pelos indivíduos do grupo controle. Também não foram encontradas diferenças significativas entre as forças produzidas dos lados direito e esquerdo no grupo controle, e também, não foram encontradas tais diferenças no grupo sintomático entre as forças produzidas no lado com ou sem desordem. 
BARBENEL ${ }^{13}$, em 1974, explanou que, durante a mastigação e mordida, os músculos da mastigação geram forças que são aplicadas pelos dentes aos objetos mordidos. Segundo o autor, é possível que também sejam transmitidas forças através da articulação temporomandibular, mas a medida direta de tais forças é difícil. Então, para esclarecer se a articulação suporta cargas durante a função, o autor realizou uma análise mecânica da articulação através de um estudo teórico e eletromiográfico. Para isso, ele se utilizou de equações de equilíbrio da mandíbula sob uma carga estática e de um método de eletromiografia integrada, após o que ele fez uma estimativa das forças na articulação com a mandíbula sustentando uma carga estática no incisivos e caninos. A conclusão a que o autor chegou foi que a articulação temporomandibular suporta cargas durante a função sob as condições de carga oclusal analisada, e que a força articular presente durante a análise eletromiográfica foi pelo menos 2,7 vezes maior que a carga oclusal.

HEKNEBY ${ }^{73}$, em 1974, investigou se a carga na ATM era maior quando a pressão vertical era aplicada sobre o primeiro pré-molar, ou sobre o segundo molar do mesmo lado, com a pressão em ambos os testes sendo a mesma. Para tal objetivo, cálculos e análises físicas foram realizados em 25 mandíbulas de cadáveres, medidas por meio de um simetrógrafo de Schwarz. Os cálculos mostraram que houve uma maior carga na ATM quando a pressão vertical foi aplicada ao primeiro pré-molar do que no segundo molar, isso foi devido no que o braço de torque do primeiro pré-molar era muito maior do que o do segundo molar; além disso, 
a ATM do lado da pressão esteve sempre sob carga durante a pressão vertical nos dentes. Do lado em que não havia pressão, a força resultante simulada dos músculos foi um pouco maior que a carga na articulação. O autor concluiu que uma grande carga na ATM pode ser um fator em sua deformação.

Uma pesquisa descritiva dos sinais e sintomas associados com a síndrome dor-disfunção miofascial foi realizada por BUTLER; FOLKE; BANDT $^{25}$, em 1975. Para isso, foram tabulados os sinais e sintomas de 56 pacientes com síndrome dor-disfunção miofascial, entre 16 e 73 anos de idade. Muitos pacientes tinham consciência de seu bruxismo e foi comum a história de distúrbios do trato gastrointestinal. Os pacientes foram classificados por sexo, idade, nível de instrução e profissão, freqüência das queixas de dor, relações oclusais, hábitos bucais e músculos específicos sensíveis à palpação. Foi observada uma coincidência entre estresse e tensão e o início da dor miofascial, sendo sugerido que a dor miofascial poderia estar relacionada ao sexo, sendo mais comum em mulheres (84\%) que em homens. Não se observaram diferenças significativas entre pacientes com disfunção mandibular e pacientes assintomáticos. A sensibilidade muscular foi particularmente associada com os músculos masseter, temporal e pterigoideo lateral e medial. Houve associação da cefaléia aos sintomas musculares, especialmente com a sensibilidade do músculo temporal anterior. 
BENSON; EPSTEIN ${ }^{16}$, em 1975, afirmaram que a existência do efeito placebo no tratamento de várias doenças é um fenômeno bem substanciado, embora não se saiba quanto do efeito atribuído ao placebo é de fato devido a alterações espontâneas no processo da doença. Para os autores, o efeito placebo parece depender de uma combinação de fatores envolvendo o paciente, o terapeuta ou o relacionamento entre ambos. Além do mais, as expectativas do paciente e o convencimento da eficácia do método de tratamento exercem uma forte influência na quantidade de alívio fornecido por um placebo. Segundo os autores, não pode haver dúvidas de que o placebo deriva seu poder do vasto potencial exercido pelo relacionamento emocional entre o profissional onipotente e as necessidades dos pacientes, a fim de que efeitos não específicos sejam maximizados, devendo haver congruência entre o acesso do profissional à terapia e a atitude do paciente em relação à doença e às expectativas no tratamento. Quando essa congruência é fraca, nenhum efeito placebo favorável é observado.

MANSOUR; REYNICK ${ }^{114}$, em 1975, verificaram os momentos e forças oclusais utilizando microtransdutores e técnicas modificadas de radiografia cefalométrica em um homem adulto. Assim, mapas mandibulares das forças foram obtidos para as seguintes localizações: incisivo central inferior, primeiros pré-molares direito e esquerdo e primeiros molares inferiores. Os autores verificaram que: a) que a média da magnitude da força de mordida variou por um fator de nove entre 
os dentes posteriores (202,5 lb) e anteriores $(22,5 \mathrm{lb})$; b) a força média gerada no segundo molar é de $10 \%$ maior do que no primeiro molar.

Comparações diferentes em relação à carga sofrida nos dentes, foram estudadas por $\operatorname{MCADAM}^{116}$, em 1976, quando o esquema oclusal adotado era pela guia canina e por função em grupo. Segundo o autor, durante a função em grupo, o primeiro contato dentário durante o golpe de trabalho da mandíbula é feito em uma localização relativamente lateral e é seguido por um deslizamento até, e talvez, além da oclusão cêntrica. Uma vez que o primeiro contato, nesse esquema oclusal, é em uma posição excêntrica e sobre um plano inclinado, a força é de torção, gerando maiores cargas horizontais. Ao se usar o guia pelo canino, a carga funcional está axialmente dirigida pela limitação do contato das cúspides de suporte dos dentes posteriores com suas fossas oponentes em ou próximas à posição de intercuspidação. Todos os contatos laterais são impedidos pelas inclinações mais íngremes dos caninos. O autor concluiu o trabalho relatando que as oclusões com guia pelo canino e por função em grupo são consideradas normais e que a última ocorre naturalmente devido ao desgaste oclusal.

De acordo com WEINBERG ${ }^{181}$, em 1976, os dentes agem como fulcro na cinética mandibular, pois não são deslocáveis em qualquer grau significativo em resultado da força muscular, ao contrário do côndilo. Assim, o fulcro está localizado na região de contato dos dentes posteriores, tornando o braço de potência, a distância do fulcro à fonte de potência. 
Ainda, segundo o autor, com uma localização mais posterior do fulcro, os braços de potência e trabalho serão mais curtos e as forças compressivas sobre a ATM se reduzirão. Assim, os contatos dos dentes posteriores nas excursões mandibulares laterais no lado de trabalho ajudariam a proteger a ATM de deslocamento condilar superior. Isso porque o contato oclusal posterior nas excursões laterais coloca o fulcro quase na linha de força do músculo masseter, que efetivamente reduz seu braço de alavanca sobre a ATM. Dessa maneira, se uma oclusão protegida pelo canino for utilizada, o braço de potência do masseter é aumentado submetendo a ATM a maiores forças de deslocamento compressivo.

A fim de verificar o efeito placebo no desgaste oclusal, em 1976, GOODMAN; GREENE; LASKIN ${ }^{60}$, conduziram um experimento clínico em 25 indivíduos com SDDM, nos quais foram realizados falsos procedimentos de ajustes oclusais. Após a avaliação inicial dos sintomas, os pacientes foram expostos a uma variedade de questões, comentários que enfatizaram a importância da oclusão nos problemas da SDDM e que era fundamental o ajuste oclusal para o alívio dos sintomas da SDDM. Assim, foi realizado o ajuste limitado somente nas superfícies não ocludentes, tais como a vestibular dos molares superiores ou a lingual dos mandibulares superiores. Após o falso desgaste, foi solicitado aos pacientes que relatassem quaisquer mudanças nos sintomas. Então, dos 25 indivíduos, 16 (64\%) tiveram uma remissão total ou quase total dos sintomas de SDDM, após os dois falsos ajustes. Os autores, assim, concluíram que a maioria 
dos pacientes com SDDM pode ser tratado com sucesso com várias formas conservativas e reversíveis de terapia.

Utilizando dois grupos de 100 crânios secos de cadáveres, MONGINI ${ }^{124}$, em 1977, fez uma avaliação clínica e anatômica da relação entre a articulação temporomandibular e a oclusão. O primeiro grupo era completamente ou parcialmente edentados e o $2^{\circ}$ grupo tinha a dentição completa, mas com graus variados de abrasão. No $1^{\circ}$ grupo, o exame foi executado por meio de um microscópio e no $2^{\circ}$ grupo por um computador, através de cálculos obtidos pelo índice de abrasão identificados nos dentes inferiores. A morfologia condilar foi individualmente verificada em termos de forma, extensão e direção das faces da articulação. Os dados clínicos foram obtidos de 17 homens e 52 mulheres com síndrome de dor e disfunção. Além disso, a oclusão também foi estudada por registro intra-oral do arco gótico e montagem dos modelos em 40 pacientes. Os autores verificaram, com a comparação dos dados, que as condições oclusais determinaram o curso do remodelamento condilar e levaram a mudanças marcantes nas formas das articulações.

Em 1977, HELKIMO; CARLSSON; HELKIMO ${ }^{74}$, registraram a força da mordida em 68 mulheres e 57 homens, utilizando um aparato de metal especificamente desenvolvido para tal propósito. A força de mordida foi medida colocando-se o aparelho entre os primeiros molares e entre os incisivos. Com intuito de fazer uma comparação, a pressão feita pela apreensão do aparelho entre o dedo polegar e o indicador, executada o mais 
forte possível, foi também medida. Os autores verificaram que os valores médios de força foram mais elevados para os homens do que para as mulheres. Nos homens, a força máxima de mordida, medida na região do molar, foi $38 \mathrm{~kg}(382 \mathrm{~N})$ e $18 \mathrm{~kg}(176 \mathrm{~N})$ na região de incisivo. Os valores correspondentes para as mulheres foram $22 \mathrm{~kg}(216 \mathrm{~N})$ e $11 \mathrm{~kg}(108 \mathrm{~N})$. A força de apreensão do dedo polegar para os homens foi em média $10 \mathrm{~kg}$ $(98 \mathrm{~N})$ e para as mulheres, $7 \mathrm{~kg}(69 \mathrm{~N})$. Além disso, os autores notaram que a força executada nos dentes naturais era maior que no grupo de próteses totais e que ela diminuiu conforme o aumento da idade pela deterioração da dentição.

De acordo com $\mathrm{KAHN}^{83}$, em 1977, quando os dentes anteriores, particularmente os caninos não se relacionam adequadamente para desocluir os dentes posteriores, a possibilidade do aumento de tensão nas articulações é alarmante, podendo ocasionar trismo, crepitação e dor.

Para BRODERSON ${ }^{23}$, em 1978, as guias são fundamentais, pois os contatos que nelas ocorrem ativam o sistema neuromuscular para fechar a mandíbula em posição cêntrica, fazendo com que as forças de fechamento sejam verticalmente direcionadas nos dentes posterior. O autor também considera que a oclusão dos dentes anteriores é a chave para se desenvolver e se perpetuar uma oclusão "ideal", pois os dentes anteriores protegem os dentes posteriores, desocluindo-os em posições excêntricas, e os dentes posteriores protegem os dentes anteriores, recebendo a maioria das forças de fechamento em posição cêntrica. 
Um tratamento foi realizado por LOUS $^{102}$, em 1978, acoplando um pivô a uma placa na região do segundo molar, de maneira a promover desoclusão de todos os dentes restantes no fechamento. 60 indivíduos que possuíam estalido em um ou ambos os lados, associado ou não a outros sintomas de síndrome da ATM foram investigados. Os indivíduos foram divididos em 4 grupos, sendo o terceiro grupo composto por 11 e o quarto, por 43 indivíduos. Os autores verificaram que o resultado do tratamento foi satisfatório em $71,7 \%$ dos indivíduos do grupo IV, e aceitável em $18,3 \%$ do grupo III, considerando que o pivô é um bom tratamento para a síndrome da ATM.

A avaliação e eficácia do tratamento nas desordens temporomandibulares foram realizadas por YATANI et al. ${ }^{194}$ em 1978 , em 260 indivíduos, através de um questionário que levantou todas as informações relativas a seus resultados. Os participantes foram divididos em dois grupos de tratamento: a) aqueles que se submeteram a alguma terapia oclusal (fase II) depois de terapias reversíveis bem sucedidas (20 homens e 114 mulheres); b) aqueles que se submeteram apenas a terapia reversível (33 homens e 93 mulheres). Os participantes foram depois, diferencialmente diagnosticados em cinco subgrupos de diagnóstico de DTM, baseando-se em exame clínico, tomografia ou ressonância magnética. Apenas $12,3 \%$ da população estudada relataram a não-melhora dos sinais e sintomas, e os demais tiveram seus sinais e sintomas reduzidos. Assim, os autores sugeriram que a maioria dos sinais e sintomas de DTM melhoram em um nível aceitável apenas com a terapia reversível. 
Para avaliar clinicamente a resposta da sintomatologia da ATM às placas oclusais de resina acrílica de cobertura total, como único meio de tratamento, CARRARO; CAFFESE $^{28}$, em 1978, selecionaram 170 registros entre 400 pacientes tratados da disfunção da articulação temporomandibular. Todos os pacientes utilizaram uma placa de cobertura total por pelo menos 6 meses, apenas retirando-a para se alimentar. 0 período de avaliação variou de 6 meses a 4 anos. A resposta ao tratamento foi classificada da seguinte forma: curado, quando todos os sintomas desapareceram; melhorado, quando os sintomas desapareceram parcialmente; pior, quando o paciente não respondeu à terapia. Os pacientes foram classificados em 3 grupos de acordo com a sintomatologia inicial: 1) apresentando apenas dor (muscular ou ATM; 2) apresentando disfunção (quando possuía click ou incoordenação mandibular); 3) dor e disfunção. Os autores concluíram que: a) ambas as sintomatologias de dor e disfunção foram beneficiadas pela terapia com placa oclusal; b) a resposta à dor será bem melhor que a resposta à disfunção no tratamento com a placa oclusal; c) $80 \%$ dos pacientes portadores de síndrome da ATM melhoraram ou serão curados quando a única forma de tratamento for a utilização de uma placa oclusal total.

CLARK et al. $^{37}$, em 1979, avaliaram as alterações na atividade de músculos em indivíduos submetidos à terapia com placa oclusal. Essa avaliação foi feita em 25 indivíduos com sintomas de dor miofascial e função mandibular anormal. Foi utilizado uma unidade de registro EMG portátil em cada indivíduo que era ativada à noite após os 
indivíduos terem ido dormir. O nível de atividade noturna do músculo masseter foi monitorado, assim como os sintomas antes, durante e após a terapia com placa oclusal. Os autores observaram que houve uma diminuição de $52 \%$ na atividade muscular durante o tratamento; em $28 \%$ não foi demonstrada alteração e em $20 \%$ foi demonstrado um aumento nos níveis noturnos. Além disso, houve um retorno aos níveis EMG prétratamento em $92 \%$ dos indivíduos após a remoção da placa e a placa foi mais passível de reduzir os níveis EMG noturnos em pacientes com sintomas menos severos.

Uma análise quantitativa das adaptações nas articulações temporomandibulares à função protrusiva em vinte e oito macacos da Índia, foi realizada por MCNAMARA; CARLSON ${ }^{117}$, em 1979, sendo os animais divididos igualmente em dois grupos: experimental e controle. Os animais experimentais foram mortos para análise da articulação temporomandibular em vários intervalos de 2 a 24 semanas após a colocação de um dispositivo que induziu a mandíbula em função a uma posição anterior e inferior. Os autores verificaram que houve respostas adaptativas na camada précondroblástica de cartilagem condilar dentro de duas semanas depois da cimentação do dispositivo. Essa resposta adaptativa foi primeiro observado ao longo da borda posterior do côndilo mandibular, enquanto as adaptações posteriores ocorreram na região póstero-superior. Nenhuma alteração no crescimento da região superior foi observada. Portanto, esse estudo demonstrou que respostas adaptativas significantes podem ocorrer no 
côndilo de macacos da Índia após a alteração na posição funcional da mandíbula.

MONGINI; CALDERALE; BARBERI ${ }^{126}$, em 1979, estudaram a relação entre a forma e a estrutura do osso condilar e mandibular, e os padrões de estresse que se desenvolveram na superfície mandibular quando eram simuladas cargas oclusais. Para essa finalidade, foram utilizados exame radiográfico, um aparelho de medida eletrônica digital e uma técnica fotoelástica em dez crânios humanos. Cada mandíbula foi, então, colocada em oclusão cêntrica com réplicas metálicas do arco superior e fossa glenóide e ajustada em uma moldura de sustentação. As cargas oclusais foram simuladas e registradas em luz polarizada plana. Os autores verificaram que na mandíbula humana existe uma relação consistente entre a direção das tensões principais, experimentalmente induzidas, a direção de trabeculado ósseo e a forma e orientação do côndilo. O fato de a maior parte dos estresses no ramo serem dirigidos para o côndilo pode explicar o grau pronunciado de remodelamento ósseo no côndilo e suas alterações conseqüentes na forma.

Ao realizarem revisão de literatura, em 1979, WODA; VIGNERON; KAY ${ }^{189}$, verificaram, em relação aos contatos oclusais funcionais e não funcionais, que: 1) contatos em oclusão cêntrica não correspondem a nenhum conceito de oclusão ideal atualmente conhecido; 2) a proteção pelo canino e a função em grupo parecem corresponder a dois estágios sucessivos de uma dentição envolvida nos efeitos de abrasão, e 
que o canino parece ser o dente mais envolvido nos movimentos de lateralidade; 3) existem contatos dentários, durante a mastigação, que ocorreram mais freqüentemente durante os movimentos de lateralidade; 4) durante a mastigação unilateral, a mastigação de alimentos é realizada tanto por contatos de trabalho, quanto de não-trabalho; 5) oclusão cêntrica é a oclusão mais freqüentemente usada durante a mastigação. É, também, a posição oclusal na qual as forças mastigatórias são maiores.

Um estudo envolvendo 33 indivíduos com dor muscular e articular, utilizando placa estabilizadora durante quatro semanas e por um período de 24 horas, foi realizado por OKESON; KEMPER; MOODY ${ }^{133}$, em 1980. Catorze regiões musculares e articulares foram palpadas antes e após o tratamento, e os índices de dor e a distância interincisal máxima (confortável e não), também foram registrados antes e após o tratamento. Os pacientes foram divididos em dois grupos, de acordo com a duração dos sintomas (pacientes agudos: 6 meses ou menos; pacientes crônicos: mais de 6 meses). Os seguintes resultados foram observados: 1) dos 33 pacientes, 28 demonstraram melhora no índice da dor; 2) dos 33 pacientes, 27 demonstraram aumento na distância interincisal confortável máxima (o aumento médio nessa distância foi de $5,3 \mathrm{~mm}$ ); 3) dos 33 pacientes, 21 demonstraram um aumento na abertura máxima; 4) quando os pacientes foram divididos em dois grupos, de acordo com a duração dos sintomas, não houve diferença significativa entre os sintomas dos grupos ou em suas respostas ao tratamento. 
BAKKE; MOLLER ${ }^{9}$, em 1980, avaliaram a atividade elétrica dos músculos masseter e temporal anterior e posterior na mordida máxima em 4 indivíduos. A interferência foi feita com camadas de tiras de 0,05; 0,10; 0,$15 ; 0,20$, colocadas nos primeiros molares, tanto do lado direito como do lado esquerdo, e comparadas com o nível de atividade com a oclusão em repouso. O contato unilateral prematuro causou uma assimetria significante na ação de todos os músculos, com atividade mais forte no lado ipsilateral. Com a espessura aumentada da camada das tiras, a atividade diminuiu em ambos os lados.

$$
\text { GOHARIAN }^{58} \text {, em 1980, estudaram doze mulheres e cinco }
$$
homens com dor na ATM ou na face utilizando uma placa estabilizadora de dia e à noite, por períodos que variaram de 3 semanas a 1 ano. Pela avaliação clínica, os autores verificaram que $76,4 \%$ delas tinham dor muscular, $70,5 \%$, dor na ATM, 88,2\%, desvio mandibular, $47 \%$ apertamento ou bruxismo e $24,4 \%$ ruído articular; após o tratamento realizado, tanto os problemas na ATM como os musculares melhoraram de maneira semelhante a um índice maior do que $80 \%$.

Para calcular todas as forças musculares e as forças nas articulações temporomandibulares, durante a mordida bilateral nas diferentes localizações da dentição humana (primeiro pré-molar, primeiro e segundo molares), PRUIM; JONGH; BOSCH${ }^{143}$, em 1980, utilizaram um modelo matemático. Para calcular essas forças, as informações sobre a atividade eletromiográfica (EMG) dos músculos da mastigação e das forças 
de mordidas medidas bilateralmente, como também informações geométricas quantitativas (obtidas através de cefalogramas laterais e frontais padronizados), foram utilizadas para alimentar um programa de cálculo. Essas informações foram obtidas através de experimentos feitos em 7 indivíduos. Através dos resultados desses cálculos, que foi ainda submetido a várias equações, levou-se à soma de ambas as forças na articulação temporomandibular e nos músculos pterigóideos laterais. Os autores chegaram às seguintes conclusões; a) forças máximas de mordida são mais freqüentemente exercidas na região de primeiro molar, pois apenas nessa região todas as forças dos músculos elevadores alcançam 90\% de seu máximo; b) as forças nos músculos pterigóideos laterais e nas articulações temporomandibulares, aumentam quase linearmente devido ao aumento nas forças de mordida.; c) forças articulares consideráveis podem ser esperadas durante a mordida; elas aumentam na medida em que uma força de mordida constante é movimentada em direção aos incisivos.

DAHLSTROM et al. ${ }^{40}$, em 1982, fizeram uma comparação entre a terapia com biofeedback e a terapia com placa oclusal em 30 indivíduos com disfunção mandibular, que foram igualmente divididos em 2 grupos: $01^{\circ}$ grupo, recebeu uma placa para ser usada só durante à noite por 6 semanas, o outro grupo recebeu treinamento de biofeedback por até 6 meses e 30 min por sessão. Um mês após o término da terapia, os pacientes foram reexaminados. Ambos os grupos demonstraram uma redução significativa nos sintomas, tanto subjetivamente, como clinicamente e não houve diferença estatisticamente significante entre os mesmos. Os 
dois tratamento, portanto, foram igualmente efetivos em curto prazo, em pacientes com níveis e sintomas de disfunção mandibular.

BREHNAN et al. ${ }^{17}$, em 1981, mediram as forças diretamente na articulação temporomandibular durante a mastigação, pela implantação de um filme prezoelétrico nas cabeças dos côndilos de sete macaca arctoide. Para isso, uma folha sensível à pressão de $9 \mu \mathrm{m}$ de espessura foi implantada na cabeça do côndilo. Essa folha detecta a pressão devido a um efeito prezoelétrico, o qual também foi conectado a um amplificador de maneira a converter essa carga em uma voltagem análoga, que foi então, registrada em um gravador de gráfico. Os autores chegaram às seguintes conclusões: 1. As cargas no côndilo foram mínimas (1-3lb) durante a mastigação posterior de alimentos macios e duros; 2. Durante a mastigação de alimentos na região anterior, a carga (3-4lb) no côndilo é maior do que na mastigação posterior. Foi demonstrado, durante a calibração do transdutor, que na medida em que o côndilo transladava para frente, sobre a eminência articular durante a abertura, era produzida sobre ele uma carga tão grande quanto a carga apresentada durante a mordida incisal. Segundo o autor, uma vez que esses registros foram obtidos com sucesso em apenas um animal, as observações acima devem ser confirmadas com experimentos futuros.

As forças oclusais durante a mastigação e deglutição medidas por transmissão sonora, foram avaliadas por GIBBS et al. ${ }^{56}$, em 1981. Isso foi realizado por um transdutor de força mantido numa armação 
preso à cabeça e fixado sobre o queixo. Os autores verificaram que: a) as forças oclusais durante a mastigação $(58,7 \mathrm{lbs}, 26,7 \mathrm{~kg})$ são altas, cerca de $40 \%$ da força de mordida máxima do indivíduo; b) as forças de deglutição $(66,4$ lbs, 30,2 Kg) foram maiores que as forças de mastigação. Os autores concluíram que a guia anterior não parece expor os dentes às forças laterais extremas, e que os contatos de deslizamento dos dentes ao entrarem e saírem da posição de intercuspidação têm curta duração e baixa magnitude com relação às forças geradas na posição de intercuspidação.

MANNS; MIRALLES; GUERRERO ${ }^{111}$, em 1981, verificaram a relação entre a atividade BT-EMG e as variações da dimensão vertical (1 a 41 mm de distância interoclusal) nos músculos masseter, temporal anterior e posterior em oito indivíduos com oclusão normal. A atividade EMG foi registrada com eletrodos de superfície, e a dimensão vertical foi medida por um dispositivo especialmente desenvolvido. Foram realizados registros com variações dinâmicas (série A) e com variações estáticas (série B) de dimensão vertical. A série A demonstrou uma redução gradual da atividade EMG começando da posição oclusal, passando através de uma faixa de redução máxima em uma certa distância oclusal, e gradualmente aumentando até os maiores valores próximos à abertura mandibular máxima. A série $B$ demonstrou a mesma progressão, apesar de apontar a dimensão vertical exata na qual é observada atividade EMG basal mínima, em cada músculo estudado (10 mm para o músculo masseter, $13 \mathrm{~mm}$ para o músculo temporal anterior e $16 \mathrm{~mm}$ para o músculo temporal posterior). 
O sistema estomatognático, de acordo com $\operatorname{LOOS}^{101}$, em 1981, pode ser esquematicamente descrito como uma alavanca de classe III, sendo a articulação temporomandibular (ATM) o fulcro, a potência o músculo masseter, pterigóideo medial e fibras anteriores dos músculos temporais. Assim, um dente localizado "anteriormente" a este vetor de potência receberá menos força que um dente adjacente. Ainda, segundo o autor, alguns dentes são incapazes mesmo de suportar forças oclusais mínimas, enquanto outros sobrevivem a extremo abuso oclusal funcional e parafuncional. Assim, aqueles sobreviventes localizados "anteriormente" à zona de potência são as seleções inteligentes para fornecer a guia dentária em todos os movimentos mandibulares excursivos, estando o canino em melhores condições para receber essa tarefa.

Usando técnicas eletrônicas e pantográficas, SIEBERT ${ }^{165}$, em 1981, investigou a guia anterior e os movimentos dentais durante a mastigação simulada (sem o bolo alimentar). Evidenciou-se, por medidas pantográficas da guia anterior, que cada tipo de oclusão foi caracterizada por um gradiente específico, com a oclusal balanceada mostrando o maior gradiente. Investigações na ausência de oclusão mostrou que a deformação elástica da mandíbula provocou os movimentos dentais. Por outro lado, movimentos tridimensionais de mais de 60 micrometros, em cada direção, ocorreram durante a oclusão. $\mathrm{O}$ autor verificou que as medidas do guia anterior mostraram que apenas a oclusão protegida pelo canino apresentou valores correspondentes aos dados fisiológicos, sugerindo que este tipo de oclusão é o único que pode prevenir movimentos vestibulares desoclusais 
dos pré-molares e molares. Além do que, movimentos dentais incorretos aumentam a desoclusão ou mesmo a oclusão traumática.

NELSON; HANNAM ${ }^{129}$, em 1982, desenvolveram um sistema interativo computadorizado que convida o usuário a selecionar as combinações de variáveis morfológicas e fisiológicas em um ambiente simulado, e que prediz as forças resultantes nos dentes e articulações temporomandibulares. Coordenadas espaciais tridimensionais são especificadas para todas as principais inserções musculares, para a posição articular e para os pontos de contato dentário. A adição de vetores e os princípios de equilíbrio estático são utilizados para solucionar a magnitude e direção das resultantes de forças. Para avaliar a confiabilidade do modelo, os autores simularam várias tarefas de apertamento dentário, utilizando informações anatômicas e fisiológicas (medidas médias), relatadas por outros autores. Os autores verificaram que o modelo previu satisfatoriamente os padrões já verificados por estudos experimentais em homens e primatas, incluindo alterações na carga dentária e articular de acordo com a localização ântero-posterior do contato dentário e o efeito de contatos dentários unilaterais sobre a distribuição de carga em ambas as articulações.

Uma análise sobre os resultados a curto e longo prazo no tratamento conservador, utilizando 175 indivíduos com síndrome de dor e disfunção miofascial, foi realizado por GREENE; LASKIN ${ }^{67}$, em 1983. Os pacientes desse estudo foram submetidos a vários tipos de tratamentos conservativos. O resultado obtido foi comparado com os obtidos em dez 
artigos publicados, nos quais os pesquisadores utilizaram métodos de tratamento irreversíveis, reversíveis ou a combinação de ambas as abordagens. A análise desse estudo revelou que, após a conclusão do tratamento, 130 indivíduos (74\%) tiveram uma grande ou total melhora dos sinais e sintomas clínicos, 43 indivíduos (25\%) pouca ou nenhuma melhora e 2 indivíduos (1\%) pioraram. Após a comparação, os autores verificaram que os resultados do tratamento, nesse estudo, foram semelhantes àqueles em todos os estudos previamente relatados, sugerindo que as terapias reversíveis conservadoras são suficientes e apropriadas para o tratamento da síndrome da disfunção miofascial na maior parte dos indivíduos.

Através do uso de placas oclusais, WILLIAMSON; LUNDQUIST $^{186}$, em 1983, verificaram o efeito de dois esquemas oclusais, na atividade eletromiográfica dos músculos temporal e masseter. O primeiro esquema oclusal permitiu que, durante os movimentos excursivos, houvesse desoclusão dos dentes posteriores pelo contato apenas do canino na placa; o segundo esquema, permitiu que houvesse contato simultâneo dos dentes na placa, durante os movimentos excursivos, tanto do lado de balanceio como do lado de trabalho e protrusivo. Os autores verificaram uma diminuição da atividade muscular nos músculos masseter e temporal quando a desoclusão posterior ocorria por uma guia anterior apropriada. Os autores também concluíram que não é o contato dos caninos que diminui a atividade dos músculos elevadores, mas a eliminação dos contatos posteriores. 
De acordo com MONGINE ${ }^{125}$, em 1983, a forma das estruturas temporomandibulares (ATM), em qualquer idade do indivíduo, é uma conseqüência da interação de diferentes fatores. Um desses fatores seria o padrão de força que pode alterar a forma da articulação temporomandibular. Além disso, movimentos mastigatórios, afetados por interferência oclusal, por mastigação unilateral que provoca restrições e irregularidades, pode modificar a carga funcional da ATM, como também o bruxismo e outras parafunções que pode ainda mais aumentar a carga sobre a ATM. Além disso, depois que o crescimento está concluído, um processo de "remodelação" continua por toda a vida e pode levar a mudanças notáveis na forma da articulação. Segundo o autor, o potencial para remodelação e mudança na forma da ATM é elevado e diretamente relacionado ao padrão oclusal e a conseqüente posição condilar na fossa glenóide.

Para comparar a efetividade da terapia com placa oclusal e procedimentos de relaxamento sob condições similares em pacientes com desordens temporomandibulares, OKESON et al. ${ }^{134}$, em 1983, utilizaram 12 pacientes que foram, aleatoriamente, selecionados para receber uma terapia com placa oclusal estabilizadora, e outros 12 para receber procedimentos de relaxamento. Após as avaliações executadas de quatro a seis semanas, os autores verificaram que no grupo que utilizou a placa, houve uma diminuição significante na dor e na sensibilidade muscular; houve, também, um aumento maior tanto na abertura máxima confortável como na abertura máxima possível, em relação ao grupo que utilizou a técnica de relaxamento. 
Os autores, portanto, concluíram que a terapia com placa oclusal é mais efetiva que a técnica do relaxamento e que esta não teve efeito significante na dor, sensibilidade muscular ou limitação da abertura nos indivíduos com DTM.

SHEIKHOLESLAM; RIISE ${ }^{162}$, em 1983, estudaram os efeitos de uma interferência oclusal sobre o padrão de atividade dos músculos masseter e temporal anterior, durante a mordida máxima, em onze voluntários com dentições naturais e completas. Os autores mostraram que durante a mordida máxima, uma interferência oclusal na posição intercúspida é capaz de perturbar o padrão quase simétrico da atividade muscular dos músculos temporal anterior e masseter. Além disso, o nível da atividade muscular durante a mordida máxima diminuiu em todos os músculos estudados. Em alguns indivíduos, a redução da atividade muscular ainda pòde ser observada uma semana depois da colocação da interferência oclusal. Após a eliminação da interferência, o padrão de coordenação muscular melhorou e o nível de atividade muscular aumentou significantemente.

Foi verificada por MANNS et al. ${ }^{113}$, em 1983, a influência da dimensão vertical no tratamento da Síndrome Dor Disfunção Miofascial. Para tal objetivo, três placas com espessuras diferentes foram analisadas em 75 indivíduos com Síndrome Dor Disfunção Miofascial, os quais foram divididos em 3 grupos: o grupo I recebeu uma placa oclusal maxilar a qual possibilitou um aumento de $1 \mathrm{~mm}$ na dimensão vertical; o grupo II, de 4,42mm e o grupo 
III, de $8,15 \mathrm{~mm}$. Os resultados mostraram uma redução mais rápida e completa dos sintomas clínicos para os grupos II e III do que para o grupo I.

O efeito das guias sobre a atividade eletromiográfica dos músculos masseter e temporal anterior, de 9 indivíduos com dentições saudáveis, foram avaliadas por SHUPE et al. ${ }^{164}$, em 1984. Para tal estudo, três variações experimentais da guia oclusal foram introduzidas: a primeira estabelecendo guia pelo canino, efetuando-se desoclusão mínima nos dentes posteriores; a segunda, utilizando o mesmo desenho da primeira, só que oferecendo uma maior desoclusão dos dentes posteriores, em relação à primeira, pelo aumento da guia; na terceira, a guia era uma placa com contato apenas nos pré-molares e molares inferiores, a qual não estabelecia contatos nos dentes anteriores. O efeito de reduzir a atividade EMG dos músculos também foi medida durante o apertamento e a mastigação. Os autores verificaram uma redução maior na atividade muscular quando os indivíduos utilizaram a guia pelo canino, sugerindo que esta deve ser utilizada a fim de que forças geradas nos dentes posteriores sejam reduzidas. Houve também uma maior redução da atividade muscular quando a guia mais inclinada foi incorporada à placa.

CLARK; BEEMSTERBOER; JACOBSON ${ }^{38}$, em 1984, avaliaram o efeito do apertamento submáximo mantido sobre a força máxima de mordida entre indivíduos com dor disfunção miofascial e indivíduos com função mandibular normal. O grupo sintomático era composto por 20 indivíduos e o grupo controle (assintomático) de 28 
indivíduos. A força da mordida foi monitorada com um transdutor da força intrabucal. Todos foram instruídos a morder até um nível submáximo de $30 \%$ e manter este nível até o ponto de tolerância à dor. Após esse tempo, foi pedido a cada indivíduo para produzir novamente uma força leve de mordida voluntária máxima. Os autores concluíram que os indivíduos do grupo sintomático tiveram um menor nível de força de mordida e um período de duração mais curto quando comparados aos indivíduos normais.

WOOD; TOBIAS ${ }^{190}$, em 1984, decidiram estudar o efeito da atividade EMG pela redução do número de dentes em contato com uma placa oclusal de resina acrílica e também determinar as alterações na atividade muscular entre o apertamento intercuspídeo e o apertamento na placa oclusal. Foram utilizados sete indivíduos com dentaduras completas e confeccionados dois tipos de placas. Os seguintes testes foram realizados: apertamento máximo com um plano de mordida equilibrado, apertamento máximo sem a placa e outros testes removendo os pontos de contato em vários dentes que estavam sob oclusão na placa. Os autores chegaram às seguintes conclusões: a) o apertamento máximo em uma placa oclusal equilibrada produziu um aumento de $17 \%$ na atividade muscular total, sobre intercuspidação máxima, principalmente pelo músculo masseter; b) o apertamento máximo em uma placa anterior produziu uma redução de $13 \%$ na atividade muscular total comparada à placa oclusal equilibrada; c) quando foi realizado apertamento máximo, com seis dentes do lado esquerdo removidos do contato enquanto o segundo molar esquerdo permanecia em contato, não houve alteração significativa na atividade muscular quando 
comparada à placa oclusal equilibrada. Quando os músculos do lado esquerdo foram comparados aos do lado direito, para a mesma situação, não houve alteração significativa; d) as alterações no número de contato dentários não causaram modificações na atividade muscular total durante o apertamento máximo e; e) as alterações no contato oclusal simétrico não causaram mudanças na simetria dos pares musculares durante 0 apertamento máximo; f) o suporte unilateral produziu resposta subjetiva de pressão na ATM contralateral durante o apertamento máximo.

Os efeitos da alteração da localização, tamanho e direção do esforço em pontos de contato específico, durante as tarefas de apertamento máximo em 10 indivíduos com dentição completa, foram estudadas por MACDONALD; HANNAM ${ }^{106}$, em 1984. Confeccionaram-se "stops" oclusais de resina para cada indivíduo os quais foram incorporados nas regiões de segundos molares nos dentes posteriores, sendo que na região anterior foram feitos dois sistemas alternativos: apenas um "stop" incisal e um bloco incisal anterior que envolvia de canino a canino. Foram executadas 14 tarefas diferentes de apertamento, variando apenas a localização dos "stops" nos dentes.Os outros verificaram que: a) os esforços de apertamento vertical na posição de intercuspidação natural ou simulada geralmente demonstraram as maiores atividades musculares para todos os músculos registrados; b) quando o ponto de contato foi movimentado para posterior ao longo do arco do incisivo para os molares, a atividade nos músculos temporais ipsilaterais aumentou, enquanto que a atividade nos músculos pterigóideo medial ipsilateral e masseter bilateralmente diminuiu durante as 
tarefas de apertamento vertical; c) esforços excêntricos em pontos de contatos específicos geralmente resultaram em menor atividade que 0 esforço vertical correspondente (isso geralmente foi observado em todos os músculos, mas nem todos os valores foram significativos); d) quando o tamanho e o número de contatos foram aumentados na anterior, houve um aumento generalizado na atividade muscular. A mesma tendência ocorreu na posterior, mas não foi tão consistente ou significativa. Os experimentos presentes demonstraram que o maior apoio suportado por um bloco incisal anterior, comparado ao oferecido por um "stop" incisal, está associado a uma quantidade considerável de atividade muscular durante o apertamento. Além do que, pacientes com colapso posterior de oclusão, que freqüentemente têm função em vários dentes anteriores, são passíveis de desenvolver mais forças reativas que pacientes com função em áreas pequenas de contato anterior isoladamente ou que suporte molar. Assim, pacientes com um colapso posterior da oclusão podem estar susceptíveis a maior carga articular durante apertamento e, conseqüentemente, predispostos a alteração ou dano tecidual na área articular.

Segundo CLARK ${ }^{38}$, em 1984, várias teorias foram propostas sobre o método de ação dos diferentes aparelhos (desencaixe oclusal, dimensão vertical de oclusão restaurada, realinhamento maxilomandibular, reposicionamento de ATM, consciência cognitiva), mas até o momento não houve, ainda, uma teoria conclusiva sobre a ação desses aparelhos. Portanto, ainda seria necessária a realização de pesquisas específicas e bem controladas utilizando medidas mais quantificáveis do efeito do 
tratamento para validar as comparações entre as diferentes abordagens terapêuticas. Para o autor, o aparelho de estabilização oclusal total é o desenho que tem a maior evidência em relação a sua efetividade. Já os aparelhos interoclusais de cobertura parcial têm complicações irreversíveis significativas, como intrusão ou erupção dentária, quando utilizado por muito tempo.

GRAHAM; RUGH ${ }^{61}$, em 1984, compararam a atividade eletromiográfica dos músculos masseter e temporal em 6 indivíduos com guia pelo canino e guia pelo molar. Mensurações de EMG superficiais integradas e bilaterais de masseter e temporal foram realizados, utilizandose quatro integradores, pré-amplificadores e um computador Al 65. Os registros foram feitos durante o fechamento em oclusão cêntrica, no movimento excursivo para o lado direito e no fechamento fazendo o mesmo movimento, só que na posição de topo a topo. Os autores encontraram uma redução na atividade EMG de $77,4 \%$ para guia pelo canino e $85 \%$ para guia pelo molar durante os movimentos excursivos. As reduções médias foram de $48,3 \%$ e $47,3 \%$ para o fechamento em posições excursivas, respectivamente, para os caninos e molares. Os autores chegaram à conclusão de que a guia pelo canino não foi mais efetiva do que a guia no molar pela redução da atividade EMG durante os movimentos laterais e durante o fechamento, e que a inibição observada pode ser devida ao número de contatos em vez de qual dente seja colocado com guia. 
Objetivando a verificação do efeito da consistência da dieta, histológica e anatomicamente, na região craniofacial, BOUVIER; HYLANDER $^{20}$, em 1984, utilizaram 30 ratos. Estes foram colocados em 3 grupos, nos quais um grupo foi alimentado com dieta mole, o outro com dieta dura e o terceiro, inicialmente alimentado com dieta mole e depois com dieta dura. Os efeitos dessas diferenças nas consistências das dietas na morfologia anatômica e histológica da região craniofacial, foi examinado. Diferenças significantes foram encontradas nas dimensões e morfologia do côndilo e cartilagem articular como resultado nas diferenças da consistência da dieta em todos os grupos. Assim, ratos com dieta mais mole usualmente tinham côndilos menores e uma camada mais fina de cartilagem articular com relação ao grupo dos ratos com dieta dura ou dieta mole/dura. Poucas mudanças foram encontradas nas dimensões gerais da mandíbula e maxila em quaisquer dos grupos.

A eficácia de placas estabilizadoras no tratamento de 20 articulações em 18 indivíduos com deslocamento de disco com redução foi verificada em 1984 por $\mathrm{CASWELL}^{29}$. O exame incluiu a história médica e física do paciente. Os estalidos foram avaliados como precoces (0-10), intermediários (10-20) e tardios (maior do que 20. Todos os pacientes tinham estalido unilateral, exceto dois que possuíam estalido bilateral tardio. Após 8 semanas, os indivíduos foram avaliados pela redução do disco e pelo tempo de estalido. O autor constatou que em $75 \%$ (9/12) dos estalidos precoces e intermitentes foi realizada a redução do disco. Nos três indivíduos em que não houve redução de disco, foi indicada placa de reposicionamento 
anterior. Em 37\% (3/8) dos estalidos tardios, a placa estabilizadora também não foi efetiva. As outras seis articulações foram também tratadas com placa de reposicionamento. Isso foi efetivo em $40 \%$ (2/5) das articulações remanescentes. Dos três discos não reduzidos, um indivíduo será operado e os outros dois estão aguardando por futura avaliação. Os resultados indicam, segundo o autor, que a placa estabilizadora é efetiva no tratamento do disco deslocado anteriormente.

MACDONALD; HANNAM ${ }^{106}$, em 1984, verificaram a relação entre o contato oclusal, o comportamento do apertamento e a resposta dos músculos específicos na interpretação da sintomatologia muscular, no bruxismo e apertamento, e na previsão de forças reativas na articulação temporomandibular. Para tal objetivo, vinte indivíduos com dentição saudável realizaram 5 apertamentos máximos para cada tarefa. Estes incluíram apertamento dos dentes, verticalmente, com esforços dirigidos para a esquerda, direita, protrusivamente e retrusivamente na posição de intercuspidação, com o máximo do movimento mandibular possível. Os indivíduos foram, também, instruídos a posicionar e apertar seus dentes inferiores sobre as inclinações linguais das cúspides vestibulares superiores. Esse apertamento foi tentado unilateralmente sobre contatos em função pelo canino e em grupo. Os autores verificaram que os músculos pterigóideo medial e o temporal são ativos durante o apertamento normal de intercuspidação. O pterigóideo medial também retém a mesma ordem de atividade durante o apertamento incisal, bem como nos esforços dirigidos de maneira protrusiva e contralateral. Ambas as partes do músculo temporal 
são igualmente ativas durante os esforços dirigidos de maneira retrusiva e ipsilateral, e estes músculos são os mais passíveis de estarem mais ativos durante o bruxismo excêntrico ou apertamento quando associado com esforço lateral ou protrusivo, com ou próximo à posição de intercuspidação. O dente no qual o apertamento ocorre tem um efeito acentuado sobre o equilíbrio da atividade entre os músculos de um par. Isso é evidente nos músculo pterigóideo medial, temporal e masseter quando os dentes posteriores estão envolvidos em esforço excentricamente dirigido. Todos os três grupos demonstraram assimetria acentuada no comportamento sob estas condições. Também é claro que a atividade nos músculos temporais aumenta na medida em que o ponto de contato se movimenta posteriormente no arco dentário, e que o músculo temporal anterior é especialmente sensível neste aspecto. Os autores demonstram que a distribuição de atividade nos músculos de fechamento mandibular, durante o apertamento, varia de forma previsível de acordo com a área de contato entre os dentes e na direção na qual o esforço é aplicado às áreas, sugerindo que seria possível correlacionar a sintomatologia com ação suposta de grupos musculares específicos em indivíduos que realizam bruxismo ou apertamento excessivo.

CLARK, em 1984, fez uma revisão de literatura sobre as interferências oclusais experimentais colocadas sobre os dentes de animais e humanos. Foram coletadas informações de 18 estudos em humanos e 10 em animais. As interferências oclusais foram agrupadas naquelas que alteram a posição de intercuspidação e aquelas que têm contato apenas na 
lateralidade. O resultado destas interferências foi analisado de acordo com seus efeitos locais pulpares/periodontais, sobre a função mandibular e bruxismo. Os autores verificaram que as interferências oclusais em intercuspidação máxima tiveram um efeito deletério sobre os tecidos periodontais e pulpares do dente afetado; às vezes isto produz alteração da função mandibular direta e ocasionalmente dor na musculatura da mastigação e clique. Já as interferências oclusais com contato apenas no movimento de lateralidade no lado do trabalho e, principalmente, no lado e balanceio, as informações sugeriram um efeito muito menos substancial sobre a função mandibular do que os contatos na intercuspidação e nenhuma evidência de dor e disfunção foi identificada. Além disso, nenhuma evidência confiável demonstra que as interferências possam causar bruxismo ou interrompê-lo. Os autores, portanto, concluem que não existem informações demonstrando que as interferências oclusais são a causa dos problemas de disfunção mandibular crônica.

A comparação de 2 tipos de placas: de reposicionamento e placa plana, no tratamento de 20 indivíduo com deslocamento de disco com redução, foi realizada por ANDERSON; SCHULTE; GOODKIND , em 1985. Os autores chegaram as seguintes conclusões: 1) o aparelho de reposicionamento produz melhora significativa subjetiva e objetiva na disfunção de pacientes com DTM com redução; 2) aparelho plano não produziu as mesmas mudanças vistas no item 1; 3) o aparelho de reposicionamento pode eliminar o estalido recíproco de DTM com redução; 4) para perceber melhora na disfunção do desarranjo interno, parece que o 
estalido recíproco deve ser eliminado; 5) o aparelho de reposicionamento produz uma melhora significativa na dor muscular associada com 0 desarranjo interno.

Com o objetivo de analisar o efeito de 4 situações oclusais diferentes (função em grupo, guia pelo canino, interferência oclusal no lado de trabalho e balanceio) em 12 indivíduos, sobre a atividade muscular nos músculos elevadores da mandíbula e no movimento mandibular, BELSER ${ }^{15}$; HANNAM, em 1985, utilizaram um sistema baseado em computadores. Os sinais EMG e de deslocamento foram coletados simultaneamente durante as tarefas funcionais (mastigação unilateral) e parafuncionais (excursões mandibulares e apertamento dentário) e analisados quantitativamente. Após o estabelecimento da guia pelo canino com coroas, houve uma redução significante da atividade do músculo elevador quando os indivíduos exerceram esforços de apertamento dentário. Com relação à mastigação unilateral, não houve alterações na atividade muscular e coordenação quando esse mesmo contato foi introduzido. Entretanto, a introdução de um contato oclusal de hiperbalanceio causou alterações significantes na atividade muscular e coordenação durante o apertamento dentário máximo em uma posição mandibular lateral. De acordo com os autores, os resultados sugerem que as oclusões protegidas pelo canino não alteram significantemente a atividade muscular durante a mastigação, mas reduzem a atividade muscular durante o apertamento parafuncional. Sugerem, também, que os contatos no lado de balanceio alteram drasticamente a distribuição da atividade muscular durante o apertamento parafuncional, e 
que essa redistribuição pode afetar a natureza das forças de reação nas articulações temporomandibulares.

O resultado em curto prazo do tratamento do clique da ATM, através do uso da placa de reposicionamento anterior (PRA) e placa estabilizadora (PE), em quarenta indivíduos que possuíam clique recíproco diagnosticado por palpação e auscultação, foi verificado por PALLA ${ }^{138}$ e ANTONNI, em 1985. Desses indivíduos, 27 foram tratados por meio de uma placa de reposicionamento, 10 através de placa estabilizadora, e um com ambos os aparelhos. O tratamento durou cerca de 4 a 12 meses. Os autores relataram que 27 dos 29 tratados com PRA estavam livres de clique no momento do exame, enquanto o clique persistiu em 2 pacientes. Em seis dos 10 indivíduos tratados com PE, o clique havia desaparecido enquanto persistia em 4 casos. Em um indivíduo, o clique desapareceu somente após a substituição da PRA pela PE. De acordo com os autores, a análise oclusal demonstrou uma falta de contato dentário posterior em 18 de 27 indivíduos tratados com PRA no fechamento sem a placa, isso não ocorrendo em todos os 10 indivíduos tratados com a PE.

Para avaliar os efeitos a curto prazo da imobilização na articulação temporomandibular do coelho, LYDIATT; DAVIS ${ }^{105}$, em 1985, utilizaram dezenove coelhos que tiveram suas maxilas e mandíbulas imobilizadas. Depois, as articulações temporomandibulares foram estudadas histologicamente após um período de 10 a 28 dias. Houve um processo de degeneração, que aumentou após um maior período de 
imobilização, e um processo de cicatrização que começou após 28 dias. Os autores concluíram que, embora, inicialmente, a imobilização produza mudanças destrutivas, elas podem ser reversíveis.

O padrão da atividade muscular durante a mastigação, por meio de um computador com programa de modelo finito, foi avaliado por OSBORN; BARAGAR ${ }^{136}$, em 1985. Para tal objetivo, um modelo tridimensional da mandíbula, confeccionado em computador, baseado em um programa linear, é apresentado. Assim, as inserções superiores e inferiores dos músculos da mastigação, vistas em um crânio humano, foram divididas em 13 unidades independentes de cada lado, num total de 26 elementos musculares. A direção (em três dimensões) e a força máxima que poderia ser desenvolvida para cada elemento muscular, a reação de mordida e as reações das articulações foram incluídas no modelo. Os autores, ao fazerem uma análise da maneira como o modelo escolhido opera, sugerem que existem dois tipos de músculos na mandíbula: os músculos de força e os de controle. Os músculos de força (masseter superficial, pterigóideo medial e alguns dos temporais) produzem a força de mordida, mas tendem a deslocar o côndilo para cima ou para baixo da eminência articular. O deslocamento é evitado pelos músculos de controle (temporal oblíquo e pterigóideo lateral), os quais possuem momentos de alavanca pobres para gerar a força de mordida, mas são eficientes para evitar o deslocamento condilar. Assim, o modelo incorpora o conceito de que os músculos consistem de elementos que podem contrair-se independentemente. Também mostra que os elementos musculares com 
braços de alavanca maiores em relação à ATM são os primeiros a serem ativados e, assim que a força de mordida aumenta, uma onda de atividade espalha-se entre os elementos com momentos de alavanca mais curtos. Em geral, o modelo pode ser usado para estudar a atividade tridimensional em qualquer sistema de articulações ou músculos.

O efeito da força de reação da ATM, num modelo bidimensional, foi estudado por THROCKMORTON ${ }^{176}$, em 1985. Para tal objetivo, um programa de computador utilizando um modelo incrementou a direção dos vetores de força dos músculos masseter e temporal gerando uma família de curvas mostrando a relação entre a direção da força muscular e a direção e magnitude da força de reação da ATM. As análises mostraram que o cálculo da força de reação da ATM é muito mais sensível aos erros na direção da força muscular do que na magnitude da força. $O$ cálculo da magnitude é menos sensível ao erro do que o cálculo da direção da força de reação da ATM. Um erro de um grau, na direção da força muscular, poderia produzir um outro erro de dois graus na direção da força da ATM. Nenhuma localização ideal foi encontrada para os vetores de força muscular. As posições dos vetores que aumentaram o cálculo da magnitude da força de reação aumentaram a sensibilidade aos erros, quando do cálculo da direção da força da ATM. Os autores concluíram que uma determinação precisa da força de reação da ATM, requer medidas precisas da direção das forças musculares e que as técnicas disponíveis ainda não o permitem. 
CHRISTENSEN $^{33}$ apresenta, em 1986, uma visão geral da fisiologia e patofisiologia das contrações musculares esqueléticas dinâmicas no organismo vivo intacto. As atividades musculares dinâmicas são divididas em contrações concêntricas com encurtamento das fibras musculares e produção de trabalho positivo, e contrações excêntricas com alongamento das fibras musculares e produção de trabalho negativo. No trabalho positivo, a tensão muscular supera as forças externas. Ainda segundo o autor, quando os músculos esqueléticos no organismo humano vivo executam uma variedade de tarefas diárias, as cargas sobre os músculos raramente são constantes durante todas as contrações musculares; e durante as alterações de comprimentos musculares, as tensões ou forças geradas geralmente se alteram. Além do que, nenhuma força contrátil é gerada quando uma fibra muscular é estimulada em menos de $60 \%$ e em mais de cerca de $150 \%$ de seu comprimento original.

SMITH; MCLACHLAN; MCCALL ${ }^{169}$, em 1986, realizaram um modelo numérico da mandíbula, simulando suas superfícies articulares e as forças exercidas com o propósito de investigar a carga na articulação temporomandibular. Esse modelo consiste de representações numéricas de uma força de mordida, as forças de três pares de músculos e as superfícies dos dentes e articulações temporomandibulares. As forças musculares representadas foram dos músculos temporais direito e esquerdo, músculos pteriogóideos laterais direito e esquerdo, alças musculares do masseter, pteriogóideos medial direito e esquerdo. As relações geométricas destes componentes do sistema mastigatório foram obtidas da medida de crânios 
secos de um homem adulto. Através desse estudo, os autores encontraram evidências que a articulação temporomandibular é uma articulação que sustenta cargas em toda a faixa funcional normal de posições e ângulos de força de mordida. Em relação a magnitude das cargas na ATM, os autores verificaram que a ATM recebeu uma carga de $60 \%$ da força de mordida quando era executada pressão sobre os incisivos e quando essa pressão era feita sobre os molares, a carga caia para $5 \%$ e diminuía mais ainda quando essas forças de mordida eram dirigidas verticalmente para 0 segundo molar. Essas cargas eram consideradas "cargas distratoras" ou seja, forças que tendem a movimentar o côndilo em direção contrária à eminência articular.

Em 1986, MONTGOMERY; THRASH ${ }^{127}$ avaliaram o efeito da placa com guia pelo canino na atividade muscular mastigatória diária. Assim, nove mulheres com sintomas clínicos de hiperatividade muscular foram selecionadas. Cada paciente, então, teve o registro feito por dois dias, sendo o primeiro sem intervenção terapêutica, e o segundo com uso constante de uma placa com guia pelo canino. Os autores verificaram que houve uma diminuição significante da atividade EMG diária no músculo masseter no uso da placa com guia, nos pacientes com sintomas clínicos de hiperatividade muscular.

Os efeitos das anormalidades dento-esqueléticas sobre as cargas na ATM foram estudados por HATCHER; FAULKNER; HAY ${ }^{72}$, em 1986, utilizando um modelo matemático e um modelo mecânico. Este 
consistiu de um crânio humano seco que foi submetido à carga pela aplicação de forças musculares sintéticas à mandíbula e medição das cargas oclusais e na ATM. Para simular essas forças dos músculos da mastigação, fibras de KEVLAR foram coladas à mandíbula e transdutores de forças foram acoplados a essas fibras que eram ligadas a um scanner e a um condicionador, sendo os resultados passados para uma calculadora. Em relação ao modelo matemático, a mandíbula foi considerada como um corpo rígido e as forças musculares, as cargas oclusais, e as reações da ATM foram modeladas como cargas de ponto. Assim, os pontos de aplicação e as magnitudes dos músculos foram determinados e as cargas oclusais e na ATM foram calculados, utilizando-se de análise de vetor tridimensional. Os autores verificaram que a articulação do lado de balanceio recebeu mais carga do que o lado de trabalho e que, em geral, as direções das cargas na ATM têm um papel significativo no equilíbrio das forças aplicadas sobre a mandíbula.

ITO et al. ${ }^{81}$ em 1986, avaliaram a carga nas ATM pela comparação dos movimentos condilares durante o apertamento nas placas oclusais que foram confeccionadas de modo a obterem contatos sob 5 condições: 1) contato oclusal uniforme e simultâneo de todos os dentes em relação cêntrica (placa de estabilização); 2) contato oclusal uniforme em posição levemente para anterior (placa de reposicionamento anterior); 3) apenas contato dental anterior (placa anterior); 4) pivôs localizados bilateralmente entre os segundos molares (que não tenham outros contatos dentais); 5) pivô localizado entre os segundos molares de um lado do arco 
dental. Nesse estudo, os pequenos movimentos mandibulares foram medidos por um sistema replicador. Para tal, 6 transdutores foto-ópticos foram montados entre os arcos faciais maxilar e mandibular e conectados na face vestibular dos dentes, não interferindo, assim, nem com a placa e nem com a oclusão dos dentes. Essa medição foi feita durante apertamento dentário em cada uma das 5 placas executadas em 5 indivíduos com dentição sadia e completa. Os autores chegaram às seguintes conclusões: a) as placas sem suporte nos dentes posteriores provocaram um movimento condilar superior de $0,44 \mathrm{~mm}$ durante o apertamento. Por essa razão, paradas cêntricas nos dentes posteriores parecem ser importantes na proteção da ATM, de carga durante o apertamento, mastigação e deglutição; b) a placa com pivôs posteriores não desviaram os côndilos; c) o apertamento na placa com pivô unilateral criou uma inclinação na mandíbula fazendo com que o côndilo do lado de balanceio se movesse para cima e o côndilo do lado de trabalho se movesse para baixo, provocando, assim, uma maior carga na ATM do lado de balanceio; d) uma grande variação de carga condilar poderia ocorrer durante a mordida unilateral e mastigação no segundo molar.

Um estudo clínico e eletromiográfico com a duração de 3 a 6 meses dos efeitos a longo prazo de uma placa oclusal sobre os músculos temporal e masseter em 31 pacientes com desordens funcionais e bruxismo noturno antes, durante e após o término do tratamento, foi realizado por SHEIKHOLESLAM; HOLMGREN; RIISE ${ }^{163}$, em 1986. Os autores verificaram que os sinais e sintomas flutuantes, bem como a atividade postural dos 
músculos temporal e masseter, foram significativamente reduzidos após o tratamento. Além disso, os coeficientes de correlação em pares de atividade postural dos músculos direito e esquerdo aumentaram significativamente. Entretanto, após a interrupção da terapia com placa, os sinais e sintomas voltaram ao nível de pré-tratamento em 1-4 semanas, em cerca de $80 \%$ dos indivíduos. Os autores concluíram que a placa oclusal pode eliminar ou diminuir os sinais e sintomas de desordens funcionais e restabelecer a atividade postural simétrica e reduzida nos músculos temporal e masseter, o que pode facilitar procedimentos tais como análise funcional e ajuste oclusal.

YAFEE; EHRLICH ${ }^{192}$, em 1987, procuraram determinar a quantidade e natureza de contatos dos dentes naturais em movimento de trabalho, desde a posição de intercuspidação à posição de topo à topo. Selecionaram 72 indivíduos e cada um foi instruído a fechar em intercuspidação e a deslizar a mandíbula para o lado de trabalho. Esse movimento foi dividido em três estágios ( $1 \mathrm{~mm}, 2 \mathrm{~mm}$ e posição topo à topo) para simular a extensão total de evento realizados no lado de trabalho e analisados por dois pesquisadores. Os autores demonstraram que o padrão de função em grupo era observado na maior parte dos indivíduos do estágio I ao estágio III. O padrão pelo canino ocorreu menos que a função em grupo. A porcentagem de oclusão pelo canino aumentou do estágio I para o estágio III na medida em que se aproximava da posição de topo à topo. Além disso, uma grande porcentagem dos indivíduos demonstrou função em grupo de um lado e oclusão pelo canino do outro, dependendo dos diferentes estágios do padrão de deslizamento. 
Segundo SCHWEIKERT ${ }^{159}$, em 1987, a guia anterior deve ser considerada como um dos fatores mais importantes na reconstrução do sistema estomatognático. Isso porque uma oclusão protegida pelo canino significa menos contatos dentários em movimentos mandibulares, causando menor chance de contatos prematuros e, dessa forma, menos chance de disfunção muscular. Além disso, devido ao fato de os dentes anteriores estarem localizados longe das articulações, eles estão em uma posição mais favorável para suportar forças laterais. Ainda, segundo o autor, outra vantagem desse tipo de oclusão é ela poder minimizar a ocorrência de problemas nas ATMs.

WILLIAMS $^{184}$ et al, em 1987, verificaram se existe quaisquer diferença na capacidade do paciente discriminar as diferenças em sua força de mordida entre 14 indivíduos que sofreram tratamento periodontal, mas tiveram seus dentes comprometidos e 14 indivíduos livres de doença periodontal. Utilizaram, para tal objetivo, um dispositivo que media a força e permitia que os próprios indivíduos monitorassem visualmente quando sua força de mordida se igualava à resistência predeterminada. Uma força de mordida de $500 \mathrm{~g}$ foi utilizada como padrão de resistência. Os resultados revelaram que a capacidade discriminatória da força de mordida dos indivíduos com doença periodontal foi significativamente menor que dos indivíduos sem doença, sugerindo, então, que os indivíduos com perda de inserção, apesar de livres de inflamação, têm função sensorial prejudicada, resultando em redução de controle sobre a força da mordida. 
GAZIT ${ }^{54}$, em 1987, verificou o efeito do estímulo mecânico (oclusal) sobre o remodelamento ósseo no côndilo mandibular do rato. Para tal estudo, uma interferência oclusal unilateral foi colocada em 15 ratos. Os animais foram sacrificados em grupos, 5, 9 e 21 dias após a confeç̧ão da placa oclusal e analisados por histomorfometria computadorizada. O estudo revelou uma taxa aumentada no remodelamento trabecular, consistindo de melhora nos números e atividades dos osteoblastos e osteoclastos. Os parâmetros de formação óssea alcançaram seus altos valores nos dias 5 ou 7 e permaneceram estáveis daí em diante. Esses resultados, segundo os autores, caracterizam ainda mais a reação da articulação temporomandibular às alterações oclusais. Os autores também sugerem que o presente aumento na renovação óssea, juntamente com a melhora conhecida na condrogênese, são parte de um processo de adaptação do estímulo funcional em resposta ao mecânico.

Durante seis semanas, RUBINOFF; GROSS; MCCALL ${ }^{146}$, em 1987, compararam o tratamento com placa estabilizadora versus placa não oclusiva em pacientes com DTM. Utilizaram 15 indivíduos que receberam a placa estabilizadora, e 13 a placa não oclusiva, confeccionada com palato, invadindo as ameias gengivais. A avaliação foi feita por um dentista (que desconhecia a modalidade de tratamento), através das alterações na abertura mandibular máxima, desvios da mandíbula e sensibilidade na região da ATM e de vários músculos. Os pacientes foram instruídos a usarem as placas por 24 horas, além de preencherem um diário de dor e classificando sua melhora geral ao final do tratamento. Foram 
observados os seguintes resultados: os índices de palpação clínica e o número de pacientes com ruídos articulares demonstraram uma redução significativa (melhora) no grupo da placa estabilizadora, mas não no grupo com placa não oclusiva. Tanto os índices semanais no diário de dor, como a classificação subjetiva de sucesso, demonstraram reduções significativas na dor em ambos os grupos. Entretanto, nenhuma das diferenças pré ou póstratamento demonstraram uma diferença estatisticamente significante entre os 2 grupos. Os autores concluíram que a placa oclusal convencional pode ser mais efetiva que uma placa sem oclusão, no alívio dos sinais clínicos da disfunção, mas ambas as placas, convencional e sem oclusão, parecem iguais no alívio de sintomas.

O efeito de cargas mecânicas na morfologia de superfície da cartilagem condilar, na mandíbula em 38 ratos, foi avaliado por BOUVIER; ZIMNG ${ }^{21}$ em 1987. Estes foram submetidos a diversas cargas mecânicas, utilizando-se dietas duras, moles, ou uma combinação entre as duas, por um período de 4 semanas (para os ratos jovens) e por um período de 12 meses (ratos adultos). Os autores verificaram que as dimensões condilares foram maiores nos grupos com dieta dura ou combinados, e menores no grupo de dieta mole. Já a superfície articular dos côndilos dos ratos com dieta dura era mais porosa e mais rugosa, enquanto que no grupo combinado e com dieta mole a superfície condilar era não porosa e ligeiramente asperizada. Os autores concluíram que alterações na consistência da dieta afetaram as dimensões do côndilo, bem como a textura da superfície do côndilo e que alterações tais como a diminuição da espessura de cartilagem são 
características com consistente restrição na carga articular. Além disso, os autores acreditam que a degeneração da superfície pode ser associada à presença de compressão anormal.

Com o objetivo de determinar a magnitude e direções relativas das cargas na articulação temporomandibular durante a oclusão unilateral máxima sobre o primeiro, segundo e terceiro molar, FAULKNER; HATCHER; HAY ${ }^{51}$, em 1987, utilizaram um modelo matemático dos grupos musculares aplicado à mandíbula humana. Para tal, com especificações já obtidas de outros trabalhos das magnitudes de força muscular, direções de cargas musculares e oclusal e seus respectivos pontos de aplicação foram utilizados, além da análise tridimensional de vetor para determinar a magnitude da carga oclusal e a magnitude e direção da carga condilar. Inicialmente, supôs-se que a carga oclusal fosse perpendicular ao plano oclusal, mas o efeito de variar sua direção no plano parassagital também foi considerado. Os autores chegaram às seguintes conclusões: a) para oclusão em qualquer uma das três posições de molar, o côndilo do lado de balanceio recebeu uma carga maior do que o côndilo do lado de trabalho (numa proporção de 2/3 da carga condilar total). Determinou-se que como a força muscular total foi de $100 \%$, encontrou-se uma carga oclusal entre 45 e $65 \%$ desse valor, enquanto os côndilos de balanceio receberam 25 e o do lado de trabalho 10 a $15 \%$; b) verificou-se pouca variação na carga condilar do lado de balanceio em relação a alterações na direção da carga oclusal; c) a direção da força no côndilo do lado de trabalho variou consideravelmente na medida em que a direção de força oclusal mudou, sugerindo que esse 
côndilo está centralmente posicionado na fossa e que age como um pivô estabilizador que recebe carga leve.

RUGH, et al. ${ }^{149}$ em 1987, compararam o efeito de uma placa com guia pelo canino com uma placa com guia pelo molar em oito pacientes bruxômanos noturnos, os quais apresentaram dor e disfunção crônica. O tratamento foi avaliado de 3 maneiras: pelos níveis de bruxismo noturnos medido pela atividade eletromiográfica do masseter, por exame clínico e pela avaliação subjetiva da dor, diariamente, através de um diário da dor. Os autores verificaram que os resultados não foram estatisticamente significantes pelas três formas avaliadas, questionando, assim, a suposição de que a guia canina é condição "sine qua non" crítica para o tratamento do bruxismo noturno e sintomas das desordens craniomandibulares.

A influência da função em grupo e pelo canino na atividade eletromiográfica dos músculos elevadores foi verifcada em 1987 por MANNS; CHAN; MIRALLES ${ }^{110}$. Para tal estudo, utilizaram 6 indivíduos com oclusões funcionais saúdaveis e ausência de disfunção do sistema estomatognático. Foram feitos registros EMG integrados dos lados esquerdo e direito, nos músculos masseter e temporal, durante as contrações máximas estática (apertamento) e dinâmica (excursão lateral e apertamento). Durante esse procedimento, as placas foram divididas de ambos os lados, distalmente aos caninos, e utilizadas em conjunto ao executar a função em grupo, e retiradas (sessões posteriores) ao executar a função pelo canino. Em ambas as situações havia uma desoclusão dos 
dentes posteriores no lado de balanceio. Os autores concluíram que: a) a posição de lateralidade com guia pelo canino, em relação à função em grupo, produziu uma atividade eletromiográfica significantemente menor dos músculos elevadores; b) a redução na atividade com a guia pelo canino sugere que o sistema estomatognático é mais efetivamente protegido contra tensão muscular eletromiográfica não fisiológica nesta posição excêntrica; c) a guia pelo canino, provavelmente, deveria ser incluída nas placas oclusais.

$$
\text { LUNDH et al. }{ }^{104} \text {, em 1988, compararam onlays }
$$
reposicionando o disco articular com a placa plana e um grupo controle sem tratamento no tratamento de deslocamento de disco com redução Sessenta e três pacientes com um diagnóstico artrográfico de deslocamento de disco com redução foram aleatoriamente distribuídos em três grupos de tratamento: 1) onlays para manter o reposicionamento do disco, II) esplintagem oclusal plana, ou III) controles não tratados. A guia para confecção das onlays de reposicionamento de disco foi estabelecida durante a artrografia para se obter uma posição recapturada do disco com relação ao côndilo. As onlays foram cimentadas aos dentes e mantiveram a nova posição de intercuspidação anteriormente e inferiormente. A esplintagem oclusal plana foi utilizada apenas à noite e foi ajustada para manter um contato oclusal máximo em relação cêntrica e oclusão cêntrica. Os exames clínicos foram realizados antes e após 6 meses de tratamento. As onlays de reposicionamento do disco melhoraram a função articular e reduziram a dor articular e muscular quando comparadas com a esplintagem oclusal plana e com o não-tratamento. Os sinais e sintomas no grupo de esplintagem oclusal 
plana não foram diferentes daqueles no grupo controle. Os autores concluíram que as onlays de reposicionamento do disco são efetivas na redução da dor e disfunção associada com deslocamento de disco com redução em pacientes nos quais o mesmo pode ser mantido em uma relação normal com o côndilo, por meio de auxílio de tais onlays. Entretanto, os sintomas retornaram quando as onlays foram removidas após 6 meses. Isso permite questionamento, como por exemplo, se uma alteração permanente na posição de intercuspidação é necessária para o sucesso em longo prazo

BOUVIER $^{19}$, em 1988, examinou a capacidade dos tecidos da articulação temporomandibular em se adaptarem às mudanças nas demandas funcionais, em ratos jovens e em fase de crescimento, comparando-as com ratos adultos. Os ratos foram submetidos a rações de diferentes consistências. O primeiro grupo foi alimentado com dieta mole (grupo experimental), o segundo foi alimentado com dieta dura e o terceiro grupo inicialmente com dieta dura e dieta mole, trocando-se, depois, para uma dieta dura, no meio período do experimento. As dimensões do côndilo, mandíbula e maxila foram medidas com um paquímetro e a espessura da camada articular, quantidade de osso na região subcondilar e no pescoço condilar foram medidas em cortes histológicos. O autor verificou que essas dimensões foram menores para o grupo com dieta mole, quando comparado aos dois outros grupos, tanto nos ratos em crescimento como nos adultos. Já o grupo de dieta mole/dura dos ratos adultos mostrou uma redução significativa na espessura da zona articular da cartilagem condilar comparado ao grupo de dieta dura. Havia, também, camadas proliferativas e 
zonas transicionais mais finas nos ratos adultos alimentados com dieta mole/dura. Em contraste, todas estas zonas mostraram recobrimento total nos ratos jovens alimentados com dieta mole/dura. Esses dados sugerem que o aumento de idade pode diminuir a capacidade da ATM de se adaptar à função e, conseqüentemente, pode ter um papel significativo no desenvolvimento da doença degenerativa da articulação.

As relações de contato entre os dentes na posição retruída e no lado não funcional em dois grupos com faixa etária diferentes de 15 e 22 anos, livres de sinais e sintomas de DTM, foram investigadas por AGERBERG; SANDSTROM ${ }^{1}$, em 1988. As relações de contato no lado não funcional foram registradas em quatro posições diferentes da mandíbula. Os autores encontraram que: a) em $75 \%$ de ambos os grupos, houve contatos dentais unilaterais na posição retruída; b) $6 \%$ a $13 \%$, no grupo de adolescentes (15 anos), de contatos no lado de balanceio nas quatro diferentes posições, e $9 \%$ a $25 \%$ entre os adultos; c) não menos que $88 \%$ e $89 \%$ dos indivíduos de ambos os grupos, respectivamente (adolescentes e adultos), tiveram pelo menos um contato oclusal, usualmente definido como uma interferência, em um ou mais das novas posições registradas da mandíbula. Os autores concluíram que devido ao fato de os indivíduos apresentarem um sistema mastigatório em bom funcionamento, esse estudo não suporta a opinião de que a mera presença das interferências oclusivas seja de maior importância na etiologia da disfunção mandibular. 
O efeito da atividade eletromiográfica dos músculos masseter e temporal anterior foi comparado, em 1988, por GRAHAM; $\mathrm{RUGH}^{62}$, quando do apertamento na posição de intercuspidação durante o movimento lateral e o apertamento no movimento lateral sobre uma placa oclusal, na qual foram feitas modificações para estabelecimento de guia pelo canino e guia pelo molar. Foram utilizados como amostra, 10 indivíduos sem dor e disfunção de articulação temporomandibular e com dentição completa. Os autores observaram que não houve diferença na atividade EMG durante o movimento lateral e apertamento excursivo com a guia pelo canino comparada à guia pelo molar. Segundo os autores, por esses resultados não se pode concluir que a guia pelo canino não seja clinicamente útil, ao contrário, o fato de ela ser facilmente obtida a credencia como um argumento convincente para a sua utilização freqüente na clínica odontológica.

Um modelo matemático tridimensional do sistema mastigatório humano, sendo um conjunto de 16 forças musculares e 2 forças articulares, são descritos por KOOLSTRA et al. ${ }^{87}$ em 1988. O modelo permite simulação das forças de mordida estática e forças articulares de reação para várias localizações de pontos de mordida e posições mandibulares. Os parâmetros do sistema para o modelo foram obtidos a partir de cadáver. As máximas forças de mordida possíveis foram computadas utilizando técnicas de otimização. Com esse sistema, os autores puderam simular diversas situações de força de mordida sobre uma placa oclusal em várias localizações diferentes: incisivo central, lateral, 
canino, primeiro e segundo pré-molares e primeiro e segundo molares, resultado em forças na ATM direita na ordem de $464 \mathrm{~N}, 437 \mathrm{~N}, 407 \mathrm{~N}, 384 \mathrm{~N}$, $317 \mathrm{~N}, 269 \mathrm{~N}$ e $189 \mathrm{~N}$, respectivamente. E para a ATM esquerda: $466 \mathrm{~N}, 446 \mathrm{~N}$, $427 \mathrm{~N}, 392 \mathrm{~N}, 369 \mathrm{~N}, 368 \mathrm{~N}$ e $332 \mathrm{~N}$, respectivamente. No apertamento bilateral sobre o incisivo central, a força gerada na ATM direita foi de $467 \mathrm{~N} \mathrm{e}$, com o apertamento no primeiro molar, a força gerada na ATM direita foi de $312 \mathrm{~N}$; para a ATM esquerda, a força gerada, quando do apertamento do incisivo, foi de $467 \mathrm{~N}$ e do apertamento do primeiro molar foi de $312 \mathrm{~N}$.

Avaliaram a atividade eletromiográfica dos músculos masseter e temporal anterior de 8 indivíduos saudáveis, foi avaliada por MIRALLES; MANNS; PASINI ${ }^{120}$, em 1988. Para tal objetivo, placas oclusais foram confeccionadas e divididas em três partes para registro da atividade em oito posições oclusais diferentes durante apertamento máximo, sem verificar a dimensão vertical. Os autores verificaram que a atividade do músculo masseter foi mais elevada com a placa do que sem a mesma, e a atividade do temporal foi similar. Houve, também, uma redução da atividade dos músculos quando o apertamento foi feito na seção anterior e contralateral da placa.

ROBERTS et al. ${ }^{145}$, em 1988, realizaram uma investigação clínica prospectiva em 188 pacientes com sinais e sintomas de dor e disfunção na ATM, examinando a correlação entre os sinais e sintomas clínicos e as características artrográficas da doença intracapsular relacionada ao deslocamento do disco. Procurou-se estabelecer quais sinais 
e sintomas clínicos específicos, por meio da artrografia, são os melhores indicadores da condição articulação. Os achados sugeriram que a maior parte dos sinais e sintomas clínicos não são suficientemente confiáveis para permitir a previsão da condição do disco. Os parâmetros clínicos que realmente demonstraram uma forte correlação foram testados em combinações utilizando análise discriminatória para avaliar as tendência clínica. Foi freqüentemente observado que os pacientes com posição e função normal do disco têm faixas normais de movimento mandibular, sem ruídos articulares na abertura e fechamento e sem evidência tomográfica de doença articular degenerativa. Através de tomografia multidirecional, foi comumente encontrado que pacientes com deslocamento do disco com redução têm estalido articular, desvio da mandíbula na abertura e ausência de doença articular degenerativa. Os pacientes com deslocamento de disco sem redução, freqüentemente demonstraram limitação do movimento mandibular, crepitação na abertura e fechamento mandibular, não siginificando, entretanto, alterações degenerativas associadas às tomografias multidirecionais. Os autores concluíram que os achados clínicos, isoladamente, ou os achados clínicos em conjunto com as radiografias planas da ATM, não são consistentemente precisos para determinação de planos de tratamento específicos nos diferentes estágios de desarranjos internos da ATM.

MIRALLES et al. ${ }^{121}$, em 1989, avaliou a influência da oclusão balanceada e guia pelo canino sobre a atividade eletromiográfica dos músculos elevadores em 4 portadores de prótese total. 0 estudo foi 
realizado através de registros eletromiográficos, feitos nos músculos temporal anterior e masseter durante apertamento voluntário máximo com próteses totais na posição de intercuspidação e na posição lateral com oclusão balanceada e guia pelo canino. Pelos resultados, o autor pôde observar: a) que a média do grupo na atividade EMG no músculo masseter com oclusão balanceada foi bem menor que na posição de intercuspidação, enquanto no músculo temporal anterior foi semelhante; b) a média do grupo da atividade com guia pelo canino foi menor que na posição de intercuspidação em ambos os músculos e; c) a média da ativdiade EMG com guia pelo canino no músculo temporal anterior foi menor que no músculo masseter. Portanto, os autores concluíram que devido a menor atividade dos músculos pelo guia canino, esse esquema oclusal pode ser um fator significativo para a prevenção da atividade parafuncional em pacientes desdentados.

KATONA $^{85}$, em 1989, verificou os efeitos da morfologia da cúspide e da mandíbula nas forças sobre os dentes e a articulação temporomandibular. Para esse objetivo, foi utilizado princípios básicos de engenharia mecânica para explicar os vetores de força no sistema mastigatório. O autor concluiu que a angulação da guia pelo canino, as alturas das coroas e a localização anteroposterior do contato, podem afetar significativamente as magnitudes e/ou direções de forças que agem sobre os dentes em contato e a articulação temporomandibular, sugerindo que as forças sobre os dentes aumentam em direção posterior, ao mesmo tempo em que a força sobre a ATM é diminuída. Além disso, a magnitude da força 
sobre a ATM pode aumentar significativamente se a angulação do canino for considerada.

A atividade muscular do músculo temporal e masseter em 10 indivíduos com distúrbios da articulação temporomandibular e 30 indivíduos saudáveis (controle), antes e após a terapia com placa oclusal, foi avaliada por CHONG-SHAN; HUI-YUN ${ }^{32}$, em 1989. Os autores observaram que a atividade eletromiográfica dos indivíduos do grupo experimental foi maior na posição de repouso e menor durante o fechamento máximo. Após o tratamento, os índices de atividade eletromiográfica, em alguns indivíduos (experimental), retornaram parcialmente; em outros, completamente ao nível normal. Os resultados mostraram que os músculos elevadores nos pacientes com distúrbios da ATM são hiperativos e tensos, e que a placa oclusal foi útil para o tratamento de tal disfunção.

Os efeitos imediatos da placa de estabilização sobre a simetria muscular nos músculos masseter e temporal anterior, durante apertamento submáximo em cinco níveis de apertamento, foram avaliados por HUMSI et al. ${ }^{77}$, em 1989. Esses níveis de apertamento (10\%, 20\%, $30 \%, 40 \%, 50 \%$ ) foram eletromiograficamente investigados em 2 grupos, nos quais o primeiro grupo era composto por pacientes (20), que após a colocação das placas, não necessitaram de ajuste adicional além do ajuste necessário no momento da instalação da placa. E o segundo grupo (16) era composto por aqueles que, depois de duas semanas de uso da placa, necessitaram de ajuste adicional para a completa estabilidade da mesma. A 
avaliação da simetria muscular foi eletromiograficamente observada pela comparação das atividades musculares antes e imediatamente após a inserção das placas. Os resultados demonstraram que, no grupo sem o reajuste, houve uma melhora na simetria muscular, enquanto no grupo que sofreu duas etapas de ajuste houve piora. Esses resultados confirmam a hipótese de que a placa de estabilização, quando ajustada com sucesso no momento da colocação, melhora o equilíbrio muscular. Apesar de ter havido uma piora estatisticamente significante na simetria do masseter, não foi encontrada tal resposta para a atividade do músculo temporal. Os autores concluem que as alterações imediatas na atividade do músculo masseter sugerem que a simetria muscular é uma base objetiva na avaliação do tratamento.

Uma avaliação a curto prazo (13 semanas) para se verificar a efetividade da terapia com placa do tipo estabilizadora nos sintomas da síndrome de disfunção da articulação temporomandibular foi realizada por TSUGA et al. ${ }^{177}$, em 1989. Para tal proposição, 30 pacientes com DTM apresentando dor na articulação temporomandibular e/ou nos músculos mastigatórios, sons na articulação e limitação do movimento mandibular foram investigados. Verificaram que $87 \%$ dos pacientes com dor na ATM responderam a essa terapia e mais de 50\% tiveram alívio imediato da dor depois de 4 semanas. Além disso, houve uma melhora em $78 \%$ e $68 \%$ dos pacientes em relação aos ruídos na articulação e limitação dos movimentos, respectivamente. Estes sintomas responderam mais vagarosamente que a dor na ATM. Os autores sugerem que a placa oclusal de estabilização 
deveria ser selecionada como primeira escolha dentre as muitas terapias e que dor na ATM é particularmente susceptível a esta terapia.

A correlação entre os padrões de contato oclusal do lado de não trabalho e os ruídos da articulação temporomandibular em humanos, foram verificados por MINAGI et al. ${ }^{119}$, em 1990. Para isso, os padrões de contato oclusal do lado de balanceio e os ruídos da articulação temporomandibular foram avaliados em 430 adultos jovens. A análise da correlação revelou que houve uma correlação positiva levemente significativa entre a ausência de contatos do lado de balanceio e uma prevalência crescente de ruídos articulares com a idade. Essas informações sustentam a hipótese de que certos tipos de contatos do lado de balanceio podem ser protetores para a articulação temporomandibular. Os autores concluíram que, além disso, pelo fato de os ruídos articulares aumentarem com a idade, é possível que haja um efeito cumulativo do estresse mecânico sobre os componentes da ATM, e que esse efeito é maior no lado de nãotrabalho.

Ao realizar uma revisão de literatura, em 1990, sobre guia pelo canino e função em grupo, THORNTON ${ }^{175}$, relatou que após discutidas as filosofias entre ambos os esquemas oclusais, chegou-se à conclusão de que a guia anterior é essencial para a estética, fonética e mastigação e que, cientificamente ninguém provou a superioridade de um esquema sobre o outro quando a guia anterior tem que ser restabelecida ou alterada, 
atualmente parece haver maior número de estudiosos a favor da guia pelo canino sobre a função em grupo.

A obtenção de uma oclusão guiada pelo canino com desoclusão posterior é mais simples do que a função em grupo, segundo CHASEN $^{30}$, em 1990. Para o autor, conforme os caninos se desgastam, contatos ávidos podem ocorrer nos dentes posteriores ou anteriores, tanto no lado de trabalho como no lado de balanceio. Quando isso ocorre, existem duas escolhas: se os caninos são bem suportados, eles podem ser restaurados, recriando a proteção pelo canino, ou podem sofrer um ajuste com o intuito de remover os contatos interferentes. Ainda, segundo o autor, quando a função em grupo está presente, lidar com trauma oclusal se torna ainda mais complexo, tornando o controle dos frêmitos nos dentes posteriores uma tarefa complicada. Para isso, conhecer as limitações de um ajuste oclusal seletivo e usar procedimentos adjuntos com as placas oclusais se tornam uma importante ajuda terapêutica.

BALDIOCEDA; PULLINGER; BIBB ${ }^{10}$, em 1990, analisaram a relação entre a espessura do tecido articular mole e os perfis ósseos condilares, espessura do osso compacto e desvio na forma em seções sagitais centrais de 53 articulações temporomandibulares humanas. Os autores verificaram que os perfis ósseos angulares tinham uma alta probabilidade de possuírem um tecido articular mole mais espesso no setor superior $(59 \%)$ do que nos outros perfis. Nem a espessura de osso compacto, nem o desvio na forma possuíram uma relação observável com a 
espessura do tecido articular mole, provavelmente devido ao estudo dinâmico dos tecidos articulares em articulações temporomandibulares de adultos jovens. Os autores verificaram, também, que a distribuição das categorias de espessura para o tecido articular mole não foi relacionada com a atrição dentária. Entretanto existiu alguma tendência em relação à espessura reduzida de tecido mole no setor anterior no grupo com perda de suporte molar.

JENSEN $^{82}$, em 1990, avaliou o efeito do tamanho comparativo do arco sobre o movimento mandibular e a oclusão. Segundo o autor, o primeiro efeito principal de uma alteração no tamanho do arco do normal é a perda da função do determinante anterior de oclusão. Esta falta de guia gera alterações profundas na oclusão e no movimento mandibular, com diferenças nos padrões de mastigação, na distância interoclusal e nos movimentos limítrofes. Essas alterações podem ser facilmente encontradas nas oclusões de indivíduos saudáveis. Para visualizar esses fatores, um crescimento mandibular hipotético foi utilizado. De acordo com o autor, o guia é um fator importante na oclusão e quando perdida pela ausência de função dos dentes anteriores, deve ser substituído pela função em grupo, utilizando os pré-molares e a superfície mesial do primeiro molar para fornecer conforto e estabilização, ou em último caso, estabelecer uma oclusão balanceada bilateral.

BAKKE; MICHLER $^{8}$, em 1990, verificaram a atividade muscular do músculo temporal e masseter em indivíduos com mordida 
aberta anterior e sinais e sintomas de desordens craniomandibulares. Utilizaram 22 indivíduos com mordida aberta anterior e sintomáticos e 29 indivíduos assintomáticos. Após o tratamento, que foi realizado com uma placa estabilizadora num período de 2 a 31 meses (até que os sintomas e sinais fossem eliminados ou acentuamente reduzidos), a atividade elétrica foi registrada na posição de intercuspidação com e sem a placa. Os autores concluíram: a) que a resistência durante a contração voluntária máxima dos músculos temporal e masseter, no grupo sintomático, ficou abaixo daquela dos indivíduos controle; b) durante a mordida sobre a placa com estabilidade oclusal, a atividade dos músculos se elevaram significativamente.

HOLMGREN $^{76}$, em 1990, estudou os efeitos de uma placa oclusal plana superior total sobre o nível de atividade eletromiográfica (EMG), nos músculos temporal anterior e masseter durante o apertamento máximo, em 31 indivíduos com hábito de bruxismo noturno e sinais e sintomas de desordens craniomandibular, ante e após o tratamento. Os resultados demonstraram que a placa oclusal aumentou a atividade dos músculos em 19\% dos casos, diminuiu em 19\% e não houve alteração em $29 \%$. Nos $32 \%$ restantes, as respostas EMG variaram de músculo a músculo dentro da análise no mesmo paciente. Além disso, os autores verificaram que após a terapia com a placa a longo prazo e melhora dos sinais e sintomas, o número de indivíduos com nível idêntico de atividade EMG, durante o apertamento máximo na posição de intercuspidação e sobre a placa, tendem a aumentar. 
BOYD et al. ${ }^{22}$, em 1990, investigaram as forças na articulação temporomandibular em dois macacos durante a mastigação, mordida incisal, no ato de beber e durante os comportamentos agressivos, utilizando uma folha piezoelétrica de $15 \mu \mathrm{m}$ de espessura. Um transdutor de força foi cimentado na superfície superior do côndilo mandibular. Os fios de conexão passavam da folha sob a pele até um transmissor FM, o qual foi implantado nas costas do macaco. As informações obtidas foram coletadas durante um período de 8 dias. Os autores verificaram que: a) a ATM suporta cargas e que a maior força recebida foi de $39,0 \mathrm{lb}(17,7 \mathrm{~kg})$ durante a agressão vocal enérgica.; b) as forças variaram de $34,5 \mathrm{lb}(15,7 \mathrm{Kg})$, durante a mastigação, a $28,5 \mathrm{lb}(13,0 \mathrm{Kg})$ durante a mordida incisal; c) as forças foram maiores do lado de trabalho (alimento) que do lado de não traballho (balanceio) em proporção média de 1,4 a 2,6. Além disso, uma interferência unilateral grande no molar mais distal, perturbou acentuadamente a mastigação, reduzindo as forças na ATM em $50 \%$ ou mais, e o macaco se recusou a mastigar no lado oposto à interferência.

Em 1991, GRAY; DAVIES; QUAYLE ${ }^{64}$ avaliaram os méritos clínicos no uso de dois tipos de placas com modos de ação diametralmente opostos: placa de estabilização, que visa aremover as interferências oclusais e distribuem a "carga" oclusal uniformemente, e a placa com interferência localizada apenas nas regiões de canino e pré-molar. Além disso, procuraram investigar se quaisquer características preexistentes da oclusão poderiam ser utilizadas para prever o resultado do tratamento. Para tal estudo, utilizaram 55 pacientes com DTM, os quais foram aleatoriamente 
distribuídos em dois grupos: 34 pacientes com placa estabilizadora e $21 \mathrm{com}$ placa interferente. Esse tipo de placa incorpora dois fios com "bolas nas extremidades", que intencionalmente interferiam com a oclusão na região dos caninos e pré-molares. Apesar de, proporcionalmente, mais pacientes terem melhorado após o tratamento com a placa interferente, não houve diferença estatisticamente significante entre os dois grupos. Além disso, os autores verificaram que pacientes sem uma guia anterior satisfatória (ausência de guia pelo canino e em grupo), interferência do lado de balanceio e ausência de oclusão em relação cêntrica participaram numa porcentagem maior em relação à melhora de seus sintomas.

Em 1991, fazendo uma revisão sobre o papel das relações oclusais funcionais nas desordens temporomandibulares, SELIGMAN, PULLINGER ${ }^{160}$, relataram que, embora haja evidência de que os padrões de guia possam alterar os níveis da atividade muscular, a maioria das pesquisas não sugere que um padrão de guia especial possa provocar a sintomatologia das desordens temporomandibulares ou, inversamente, melhorar a saúde. Para os autores, poucos estudos examinam populações de pacientes diferenciados, então os possíveis efeitos específicos do guia são desconhecidos. Portanto, pesquisas futuras deveriam focar-se em grupos de pacientes diferenciados.

HARKINS et al. ${ }^{70}$, 1991 fizeram um estudo duplo-cego para testar a administração de doses baixas de drogas benzodiazepínicas (clonazepan) no tratamento de DTM crônica em 20 indivíduos, os quais 
foram igualmente divididos para o grupo experimental (clonazepan) e o grupo placebo, cujos indivíduos receberam as mesmas orientações do grupo experimental e doses sem a referida droga. O estudo teria duração de 60 dias, mas como 5 indivíduos (50\%) do grupo experimental tiveram seus sintomas melhorados em 30 dias, e 7 indivíduos (70\%) do grupo placebo desistiram pela não-melhora de seus sintomas, a avaliação foi feita após 30 dias. Os autores concluíram que o clonazepan apresentou melhores resultados comparativamente ao grupo controle. Entretanto, cuidados devem ser tomados na administração em longo prazo, devido aos seus efeitos colaterais potenciais tal como a depressão e disfunção hepática.

O efeito da placa oclusal sobre a eletromiografia integrada (EMG) dos músculos masseteres de ambos os lados em 23 indivíduos com síndrome de distúrbio da articulação temporomandibular, foram verificadas por SHAN; YUN ${ }^{161}$, em 1991. Os autores relataram que o valor mioelétrico integrado do músculo masseter do lado envolvido e do não envolvido foi reduzido com a placa oclusal, concluindo que a placa oclusal pode reduzir a atividade do músculo masseter e, dessa forma, exercer um efeito terapêutico.

Para estudar os efeitos de tensão sobre a mandíbula quanto submetida a forças de mordida isométricas simuladas, aplicadas sobre os incisivos e molares $\mathrm{HART}^{71}$, em 1992, avaliou modelos tridimensionais de elemento finito de uma mandíbula humana parcialmente desdentada. $O$ presente estudo consistiu de duas partes importantes. Na primeira, uma 
série de cinco subdivisões diferentes da mesma mandíbula humana foi gerada para encontrar o grau apropriado de refinamento tridimensional de rede necessária para um modelo preciso da mandíbula. $\mathrm{Na}$ segunda, o modelo de geometria e a propriedade do material foram analisados para estudar os padrões de tensão na mandíbula quando submetida a cinco diferentes situações de carga funcional. Os autores verificaram que: a) as forças oclusais sempre são menores que as forças musculares; b) quando o modelo foi submetido a cargas, o côndilo do lado de balanceio recebeu uma força de $57,7 \mathrm{~N}$, que é o dobro da força de $27,8 \mathrm{~N}$ que age sobre o côndilo do lado de trabalho.; c) quando a atividade muscular foi maior de um lado, os côndilos do mesmo lado foram submetidos a cargas mais severas.

WILKINSON et al. ${ }^{183}$ em 1992, compararam a terapia com placa oclusal utilizada por 24 horas e durante as horas de sono. Após 8 semanas de uso, foi feita a avaliação e verificou-se que o uso noturno da placa foi melhor sucedido em pacientes que sofriam de dor miogênica, os pacientes com origem artrógena da dor se beneficiaram com o uso contínuo da placa, apesar de não ter diferença estatisticamente significante na diminuição das dores em ambos os grupos.

Esforços especiais devem ser feitos para se evitar terapia agressiva e irreversível. Isso porque, segundo MCNEILL ${ }^{118}$, em 1997, pouco se sabe sobre o curso natural da DTM, ou quais sinais e sintomas progredirão para condições mais sérias. Para tal, pode-se lançar mão de diversos tratamentos. Um deles consiste no uso de aparelhos ortopédicos. 
Segundo o autor, apesar de existir uma grande variedade de aparelhos, dois tipos são comumente utilizados no tratamento da DTM: placa de estabilização e placa de reposicionamento anterior. Os primeiros visam fornecer a estabilização da articulação, redistribuição de forças em nível dentário e/ou articular, relaxamento dos músculos elevadores (pelo menos em curto prazo) e proteção dos dentes dos efeitos do bruxismo. E os aparelhos de reposicionamento anterior são indicados para dor articular agudo, ruído articular doloroso e travamento fechado.

O efeito do tratamento com acupuntura e da terapia com placa oclusal foram comparados por LIST et al. ${ }^{98}$, 1992, em 110 indivíduos com sinais e sintomas de desordem craniomandibular, os quais haviam tido dor por mais de 6 meses. Os indivíduos foram casualmente designados para um dos três grupos: tratamento com acupuntura, terapia com placa oclusal e controle. Foram avaliados antes e após o término do tratamento. Os autores verificaram que tanto a acupuntura como a terapia com placa oclusal reduziram os sintomas quando comparadas com o grupo controle, nos quais os sintomas permaneceram sem mudanças.

SANTOS JÚNIOR; NOWLIN ${ }^{153}$, em 1992, verificaram o efeito da terapia com placa na carga exercida na articulação temporomandibular utilizando o teste de resiliência de GERBER. Esse teste é um meio clínico de avaliação de compressão ou distração nas articulações temporomandibulares em que a colocação de várias tiras de folha de estanho $(0,3 \mathrm{~mm}$ de espessura) entre os pré-molares superiores e inferiores 
no lado oposto da articulação a ser testada demonstre que, em indivíduos normas: a) haja contato dentário com apenas duas dessas folhas; b) haja separação dos dentes com três a quatro folhas indicando distração; c) separação dos dentes com uma folha indicando compressão. Esse teste foi aplicado em 18 indivíduos, dos quais 9 apresentavam um ou mais sintomas de DTM e nove eram assintomáticos. O teste foi executado antes da terapia com placa estabilizadora por um período de uma semana (uso constante no período da noite) na instalação e após uma semana depois do término do tratamento. Os autores chegaram à seguinte conclusão: a) na instalação, houve uma tendência estatisticamente significativa de as articulações apresentarem distração $(58,33 \%)$ em vez de compressão $(13,89 \%)$; b) na instalação, os valores neutros estavam presentes em $27,78 \%$ dos casos; c) após uma semana, não houve diferença estatística entre a tendência para distração $(38,89 \%)$ e os valores neutros $(41,67 \%)$ de todos os casos e houve uma pequena tendência para compressão $(19,44 \%)$ de todos os casos.

A melhor alternativa para a guia pelo canino, segundo OKESON ${ }^{132}$, em 1992 é chamada de função em grupo. Nessa função, muitos dentes no lado de trabalho contactam durante o movimento laterotrusivo. De acordo com o autor, a função em grupo mais desejável consiste no contato do canino, pré-molares e algumas vezes a cúspide mésio-vestibular do primeiro molar. Qualquer contato laterotrusivo mais posterior do que a posição mesial do primeiro molar não é desejável, devido ao aumento da força que pode ser colocada quando eles se aproximam do eixo de rotação e das forças vetoriais. 
BUCHNER et al. $^{24}$, em 1992, realizaram uma análise eletromiográfica dos músculos masseter e temporal anterior através de apertamento dos dentes sobre uma placa oclusal, em 20 mulheres com desordem craniomandibular e 20 mulheres livres de sintomas. Os autores verificaram que os indivíduos do grupo sintomático possuíam uma menor amplitude elétrica em ambos os músculos. Em todos os grupos, a atividade do músculo temporal anterior diminuiu em relação ao masseter, o que, segundo os autores, pode explicar o efeito terapêutico da placa.

A avaliação do efeito da placa oclusal sobre atividade eletromiográfica dos músculos temporal anterior e masseter em 21 indivíduos livres de sinais e sintomas de DTM, foi analisada por LOBBEZOO et al. $^{99}$, em 1993, durante apertamento máximo na posição de intercuspidação com e sem a placa. Os autores verificaram que, sem a placa, a atividade dos músculos temporais anteriores foi maior que a atividade do masseter, mas diminuiu com a colocação da placa. Já a atividade dos músculos masseteres foi menor que a dos músculos temporais anteriores, mas aumentaram com a colocação da placa.

GLASS, GLAROS e McGLYNN ${ }^{57}$, em 1993, realizaram uma pesquisa em 10.000 membros da Associação Dental Americana para identificar os tratamentos mais usados para a disfunção de dor miofascial. Utilizou-se um questionário, onde todos os tratamentos estavam relacionados. Os resultados de 2.544 questionários mostraram que os tratamentos mais usados são: placas de superfície plana com guia pelo 
canino ou função em grupo, ajuste oclusal, compressas quentes, aconselhamento, fisioterapia e medicação. (Os resultados também mostraram variações consideráveis na maneira como o tratamento era conduzido).

HOLMGREN; SHEIKHOLESLAM; RIISE ${ }^{75}$, em 1993, avaliaram os efeitos de uma placa oclusal estabilizadora na atividade parafuncional, durante o sono, em 31 indivíduos com bruxismo noturno e sinais e sintomas de desordens craniomandibulares. Os resultados revelaram que a placa oclusal não pára o hábito de bruxismo noturno. Em $61 \%$ dos indivíduos, as facetas desgastadas ativas na placa foram observadas a cada visita (intervalo de 2 semanas), e em $39 \%$, de tempos em tempos. As facetas desgastadas reapareceram na mesma localidade com o mesmo padrão e foram causadas principalmente pelo ranger dos dentes, pois em $80 \%$ dos pacientes as facetas desgastadas nas placas oclusais foram criadas pelos movimentos mandibulares laterais. Os autores concluíram que, durante o bruxismo excêntrico, a mandíbula move-se lateralmente muito além da relação de contato borda a borda dos caninos e, portanto, o ajuste oclusal parece ser uma inadequada medida para harmonizar a distribuição da sobrecarga durante o bruxismo excêntrico.

ERHARDSON, et al, ${ }^{50}$ em 1993, estudaram o efeito da posição de contato oclusal sobre o nível de força gerada pelos músculos elevadores da mandíbula e a distribuição desta força muscular sobre os dentes e côndilo durante o apertamento máximo unilateral sobre uma 
borracha em cinco regiões dentárias. Para tal objetivo, a atividade dos músculos temporal anterior e masseter foi registrada durante o apertamento máximo em intercuspidação e unilateralmente sobre os segundos e primeiros molares, pré-molares, caninos e incisivos centrais em dez indivíduos com dentição completa e sem sinais e sintomas de DTM. As atividades EMG foram convertidas em força muscular relativa e a distribuição desta força muscular relativa sobre os dentes e côndilos foi, então, calculada por meio de um modelo matemático tridimensional. Os autores verificaram que a magnitude da força muscular está fortemente associada com a localização do ponto de mordida. Assim, a maior força muscular é produzida durante o apertamento na posição de intercuspidação (100\%). No apertamento unilateral, $75 \%$ dessa força na intercuspidação é alcançada durante o apertamento sobre uma borracha nos segundo molares, $85 \%$ durante o apertamento sobre uma borracha nos primeiros molares e $45 \%$ durante apertamento nos incisivos. Os autores verificaram que as forças sobre o côndilo do lado de não-mordida pode alcançar níveis de $25 \%$ de força muscular gerada durante o apertamento máximo quando do apertamento unilateral sobre uma borracha nos primeiros e pré-molares; $35 \%$ da força máxima de mordida durante o apertamento sobre segundo molares e $70 \%$ durante o apertamento sobre os caninos. Além disso, os autores demonstraram que quanto mais posterior o ponto de mordida fosse colocado, menor era a carga sobre o côndilo do lado de mordida, isso evidenciado, quando o apertamento unilateral foi feito sobre o segundo molar, que quase não produziu carga neste côndilo. 
A fim de comparar a atividade eletromiográfica dos músculos mastigatórios (temporal e masseter) com o uso de uma placa de reposicionamento anterior e uma placa de relação cêntrica WILLIAMSON; NAVARRO; ZWEMER ${ }^{187}$, em 1993, utilizaram um grupo experimental composto por 26 indivíduos com desordens internas da articulação temporomandibular e um grupo controle de 10 indivíduos sem queixas de DTM. Com as placas colocadas, os pacientes foram instruídos a morder firmemente e manter a pressão contra a placa durante o registro, o que foi feito em posição de repouso sem as placas, na posição de intercuspidação sem as placas e em mordida máxima com as placas. Os autores verificaram uma atividade significantemente menor dos músculos masseter e temporal com a terapia utilizando a placa de reposicionamento anterior, comparada à terapia com placa de relação cêntrica superior, sugerindo que menos pressão é criada nas articulações que utilizaram a placa de reposicionamento anterior.

Em 1993, TURK; ZAKI; RUDY ${ }^{178}$ avaliaram a eficácia de dois tratamentos: placa intra-orais e biofeedback, usados sozinhos e em combinação na resolução dos sintomas das DTMs. Para tal projeto, utilizaram 80 indivíduos, para o primeiro estudo, com sinais e sintomas de DTM, os quais foram aleatoriamente divididos em 3 grupos: 30 para o grupo experimental utilizando as placas oclusais; 30 para o grupo que recebeu o biofeedback; e o controle (20) que aguardou na lista de espera. Para o segundo estudo, foram utilizados 30 pacientes com DTM os quais receberam tratamento conjunto com as placas e biofeedback/stress. As 
avaliações foram feitas após seis semanas de tratamento. Os resultados para o primeiro estudo demonstraram que o tratamento com placa foi mais efetivo que o feedback na redução da dor depois do tratamento, mas em um acompanhamento de 6 meses o grupo com placa reincidiu significantemente, especialmente na depressão, considerando que o grupo do biofeedback manteve a melhora tanto em dor como em depressão, e continuou a melhorar. Os resultados do segundo estudo demonstraram que o tratamento combinado foi mais efetivo que o tratamento usando apenas a placa ou o biofeedback, particularmente na redução da dor a 6 meses de acompanhamento. Os autores concluíram que o tratamento combinado é mais importante na solução dos sinais e sintomas das DTM, principalmente na manutenção a longo prazo do sucesso inicial do tratamento.

FITINS; SHEIKHOLESLAM ${ }^{53}$, em 1993, estudaram o efeito da guia pelo canino de uma placa oclusal superior sobre o nível de ativação dos músculos temporais anterior e posterior, masseter e suprohióideo durante o apertamento máximo em 14 indivíduos sem níveis e sintomas de DTM. Os autores verificaram que o nível de atividade eletromiográfica dos músculos temporal anterior e posterior e o suprahióideo, durante o apertamento máximo sobre a placa oclusal em fechamento habitual não foi alterado com relação à mordida na posição da intercuspidação, enquanto a do músculo masseter, em média, aumentou levemente (13\%). Por outro lado, o nível de ativação dos músculos elevadores da mandíbula diminuiu significativamente durante o apertamento máximo sobre a placa com guia pelo canino, com relação à mordida na intercuspidação ou apertamento 
sobre a placa. Entretanto, o grau de redução da atividade não foi simétrica, e foi mais pronunciada no músculo masseter do lado de trabalho e nos músculos temporais anterior e posterior no lado de balanceio

CHEN; XU ${ }^{31}$, em 1994, utilizaram um modelo de elemento finito bidimensional da ATM desenvolvido para investigar os estresses e as forças de reação dentro da articulação durante o fechamento sagital da mandíbula. Os parâmetros mecânicos analisados foram os estresses principais e máximos de von Mises, e as reações condilares. O modelo foi avaliado por vários testes. Os autores verificaram que uma força de reação resultante do côndilo foi dirigida para o lado posterior da eminência. Os estresses de contato, ao longo das superfícies condilar e temporal, não foram distribuídos igualmente. Para o deslocamento condilar de fechamento, introduzido nesse estudo, altos estresses compressivos concentraram-se na porção posterior do disco. Por outro lado, altos estresses de tensão foram concentrados no compartimento mais superior da porção média do disco. Outros parâmetros, tais como os estresses de von Mises, densidade de energia de deformação, também foram altos nestas regiões, já que as fibras do disco são suscetíveis à forças de tração.

De acordo com ISRAEL ${ }^{80}$, em 1994, as fibras colágenas mantêm a integridade estrutural da cartilagem articular pela restrição do volume dos proteoglicanos osmoticamente ativos. Este arranjo permite que as forças compressivas façam com que os proteoglicanos liberem água, desta forma fazendo com que a cartilagem articular assuma um menor 
volume. A remoção das forças compressivas faz com que a água retorne aos proteoglicanos osmoticamente ativos, restaurando o volume da cartilagem articular. Isto permite que a cartilagem articular tenha as características de deformação e resiliência.

NITZAN $^{130}$, em 1994, estudou a pressão intra-articular gerada em ATM durante a função, principalmente durante o apertamento e o efeito que a mudança de altura no plano oclusal provocado por uma placa oclusal teria nos níveis da pressão intra-articular sobre a articulação temporomandibular. Esse estudo envolveu 35 articulações de 35 pacientes que foram submetidos à artrocentese para tratamento de várias desordens de ATM. A pressão intra-articular foi medida por um aparelho de medida de pressão, o qual consistia de três partes: agulha, transdutor de força e sistema de registro. A agulha foi inserida na parte ântero-lateral da fossa, no compartimento superior da ATM, e em seguida a pressão foi medida nas seguintes posições: em repouso, abertura bucal máxima e apertamento sem e com um aparelho intra-oclusal (placa estabilizadora). Essa medição com aparelho oclusal foi medido em apenas 22 indivíduos, sendo a placa confeccionada de maneira a elevar uniformemente o plano oclusal, com $1,5 \mathrm{~mm}$ de espessura e sem os contatos entre os dentes anteriores. Esse procedimento tinha o objetivo de movimentar as forças de mordida oclusal para distal, encurtando, dessa forma, o comprimento de braço de resistência com a força resultante reduzida no fulcro, que é a ATM. O autor verificou que, durante a abertura máxima, a pressão intra-articular (PI) diminuiu, variando de -130 a $-5 \mathrm{mmHg}$ (média $-53,82 \pm 34,40 \mathrm{mmHg}$ ), enquanto 
durante o apertamento, a pressão sempre foi positiva (variação +8 a+200mmHg; média $63,90 \pm 52,25 \mathrm{~mm} \mathrm{Hg}$ ). As mulheres geraram pressões significativamente mais altas que os homens $(73,70 \pm 61,06 \mathrm{mmHg}$ versus $31,42 \pm 11,47 \mathrm{mmHg}$ ). Essa diferença, segundo o autor, entre sexos, com relação à $\mathrm{PI}$, pode ajudar a elucidar o enigma da proporção consideravelmente maior de mulheres com problemas de ATM. Durante o apertamento sem a placa oclusal, as pressões variaram de 20 a $200 \mathrm{mmHg}$ (média 68,8 $\pm 49,1$ ) diminuindo em $81,2 \%$, cujos níveis de PI variaram de 0 a 40 mmHg (média 7,9 \pm 10,9) com a placa oclusal em posição).

Algumas indagações foram realizadas por GOLDBERG ${ }^{59}$, em 1994, fez em relação ao artigo anterior (NITZAN) sobre a pressão intraarticular na articulação temporomandibular em virtude da elevação mandibular feita pela instalação de uma placa estabilizadora. Segundo o autor, o artigo mostrou observações importantes em relação ao papel das flutuações na pressão do fluido sinovial durante a função articular e com relação ao papel dos aparelhos oclusais na redução da pressão do fluido sinovial durante o apertamento. Também deixa várias perguntas sem respostas plausíveis, como por exemplo, por que os homens com suas maiores forças de mordida produzem mesma pressão do fluido sinovial durante o apertamento que as mulheres? Por que a redução drástica na pressão intra-articular durante o apertamento sobre a placa estabilizadora é explicado somente pela mecânica de alavanca de Classe III? Em resposta à última pergunta, o autor relata que, caso seja positivo, esta pode ser uma das melhores explicações relacionadas ao mecanismo de ação dos 
aparelhos oclusais. O autor conclui, portanto, que o artigo é instrutivo, provocador e que muitas das questões geradas na discussão requerem investigação adicional antes que possam ser considerados conclusivos.

Indivíduos com e sem desordens temporomandibulares foram avaliados por PAESANI, et al. ${ }^{137}$, em 1994, em relação a reprodutibilidade na atividade de repouso dos músculos temporal anterior e masseter. Para tal estudo, utilizaram 10 indivíduos assintomáticos e 5 sintomáticos, onde foram registrados três vezes em 5 sessões separadas. Os autores verificaram que não houve diferença estatisticamente significante entre os dois grupos, sugerindo que os valores das eletromiografias de várias sessões não são reprodutíveis, e que valores de sessões sucessivas são questionáveis podendo, assim, dificultar a correlação entre a atividade de repouso reduzida e o efeito do tratamento.

KIMMEL $^{86}$ relatou, em 1994, que as interferência oclusais causam tensão no sistema estomatognático. As cúspides podem agir como fulcro e transmitir a força aos músculos de maneira danosa. Para aliviar essa condição, o profissional pode fazer o seguinte: a) diminuir a magnitude da força; b) melhorar a direção da força e c) reduzir a duração de aplicação da força. Assim, a criação de uma oclusão mutuamente protegida reduzirá o estresse oclusal na dentição e estruturas de suporte. Ainda segundo o autor, no tratamento de mordida aberta anterior, o dentista se depara com os seguintes problemas oclusais: 1) não existe guia protrusiva e isso causa contato nos dentes posteriores e interferências no lado de não-trabalho; 2) 
os dentes posteriores são tensionados e os dentes mais próximos dos côndilos recebem a maior quantidade de força nos contatos oclusais. Sem guia anterior, a atividade eletromiográfica elevadora é aumentada. Então, para contornar essa situação, o autor descreve uma aparelho para tratar as desordens geradas pela oclusão, por meio da promoção da oclusão mutuamente protegida ausente nas dentições naturais de muitos pacientes, especialmente naqueles com mordida aberta anterior, largas discrepâncias de sobrecontorno e sobressaliência. O aparelho é construído de $\mathrm{Co}-\mathrm{Cr}$ e acrílico. Não é volumosos e não compromete o espaço funcional livre do paciente. É bem tolerado e apropriado para curto e longo prazo, aliviando os sintomas.

Para o tratamento das dores miofaciais dos músculos mandibulares DAO et al. ${ }^{43}$ em 1994, avaliaram a eficácia terapêutica das placas usando um projeto cego, controlado e aleatório. Para tal projeto, 63 indivíduos com história de dor miofascial de 3 meses a 12 anos foram selecionados e avaliados em 3 grupos: 1) controle passivo - composto por 20 pacientes que receberam uma placa oclusal de estabilização no maxilar usadas por somente 30 minutos em cada encontro; 2) controle ativo composto por 21 pacientes que receberam uma placa palatal em forma de "U”, a qual não cobria a superfície oclusal, nem interferia com a oclusão, usada 24 horas/dia; 3) e o $3^{\circ}$ grupo, composto por 22 pacientes, que usaram a mesma placa do controle passivo por 24 horas/dia. Em cada uma das 7 visitas, os pacientes foram avaliados pela escala de análise visual de 100 $\mathrm{mm}$ sobre sua intensidade de dor, tanto em repouso como após a 
mastigação. O efeito de dor sobre a qualidade de vida foi, também, avaliado, através de várias escalas. Os autores verificaram que não houve diferença significante entre os grupos em qualquer das variáveis pesquisadas e concluíram que a redução gradual na intensidade da dor, bem como a melhora na qualidade de vida durante a pesquisa foi não específica e não relacionada ao tipo de tratamento.

LEEUW et al. $^{95}$ em 1994, avaliaram o curso clínico da osteoartrose e desordem interna de 99 pacientes depois de mais de 30 anos, depois de terem recebido tratamento não cirúrgico. No acompanhamento usou-se, também, um grupo controle com 35 indivíduos livres de DTM. Durante os primeiros anos após o tratamento, os principais sinais de osteoartrose e desordem interna de articulação temporomandibular diminuíram significantemente. Nas três décadas seguintes, muito poucas mudanças foram observadas. Estalidos e crepitações foram os sinais remanescentes mais comuns. Esses sinais, entretanto, pareciam aborrecer os pacientes. Os autores concluíram que o uso de modalidades de tratamento não cirúrgico deveriam ser encorajados no tratamento dessas desordens e que se os sinais e sintomas não regredissem poder-se-ia partir para o tratamento cirúrgico.

Usando placa de estabilização, LEEUW JÚNIOR et al. ${ }^{96}$, em 1994, fizeram uma avaliação do resultado do tratamento em pacientes com disfunção craniomandibular. Para isso utilizaram 57 indivíduos com sinais e sintomas de DCM, dos quais 32 receberam a placa estabilizadora e os 
outros 14 participaram do grupo controle. Após a avaliação, os autores constataram que os pacientes que receberam a placa tinham menos sintomas de DCM no final do tratamento. Entretanto, muitos sintomas e correlatos de DCM (severidade da dor, barulhos articulares e dores de ouvido) também melhoraram no grupo controle. Por essa razão, os autores questionaram se todas as melhoras observadas no grupo experimental podiam ser atribuídas ao tratamento (placa) recebido.

HOLMLUND; AXELSSON ${ }^{78}$, em 1994, compararam a prevalência de osteoartrose e sinovite na articulação temporomandibular em 60 indivíduos com travamento doloroso crônico da ATM. A avaliação envolveu exame clínico (creptação), tomografia (esclerose e erosões) e artroscopia (envolvimento da cartilagem) da ATM e os 60 indivíduos foram divididos igualmente conforme a situação da arcada dentária (totalmente e parcialmente dentado). Os autores verificaram que os sinais artroscópicos de artrose e sinovite foram freqüentes em ambos os grupos. Com relação aos sinais e sintomas clínicos, sinais tomográficos de osteoartrose e diagnóstico artroscópicos, não foram encontrados diferenças estatísticas entre os 2 grupos. Os autores concluíram que o conceito de que uma prevenção contra a osteoartrose da ATM é ter seus dentes perdidos substituídos por uma prótese é inválido.

Para comparar a atividade eletromiográfica (EMG) dos músculos masseter e temporal anterior, VISSER et al. ${ }^{180}$, em 1994, utilizaram entre 61 indivíduos com desordem craniomandibular miogênica 
(DCM) e 60 indivíduos saudáveis (controle). Então, para registro da atividade muscular, foi solicitado aos indivíduos que apertassem os dentes a um nível de 10 e $50 \%$ do apertamento voluntário máximo. Os autores verificaram que os pacientes com DCM apresentaram atividade EMG do masseter mais baixa que o controle, enquanto a atividade EMG do temporal anterior não foi diferente entre os dois grupos. Houve uma maior atividade do músculo temporal em relação ao masseter nos pacientes com DCM. Não foram encontradas diferenças significantes na assimetria EMG entre os pacientes do grupo controle e do grupo com DCM. Os homens apresentaram maior atividade EMG do que as mulheres. A atividade EMG do temporal anterior diminuiu com a idade, o mesmo não acontecendo com o masseter, que permaneceu inalterado. Portanto, os autores observaram uma influência significante da DCM, da idade e do sexo sobre a atividade EMG dos músculos mastigatórios.

GRUNET et al. $^{69}$, em 1994, estudaram a atividade dos músculos elevadores da mandíbula (masseter e temporal anterior) por eletromiografia de superfície, em 17 indivíduos portadores de próteses totais. A eletromiografia inicial foi registrada com as próteses e comparada aos registros obtidos com uma placa com guia pelo canino e uma outra placa que estabelecia oclusão balanceada bilateral. Os registros foram obtidos durante uma seqüência de movimentos: posição em repouso, contato dentário máximo em posição de intercuspidação, movimento protrusivo e durante as excursões laterais. Os autores verificaram que a atividade muscular registrada com as próteses não foi significativamente 
diferente da registrada com placa com guia pelo canino. Entretanto, houve um aumento significativo da atividade muscular com a oclusão balanceada bilateral.

ALENCAR JÚNIOR ${ }^{3}$, em 1994, utilizou-se 30 pacientes portadores de sintomas compatíveis com o diagnóstico de Disfunção Craniomandibular (DCM), no grau moderada ou severa, com envolvimento miogênico predominante. Esses pacientes foram aleatoriamente distribuídos em dois grupos: grupo 1 - constituído de pacientes que utilizaram, como forma de tratamento, uma placa miorrelaxante convencional (PMRC); grupo 2 - constituído de pacientes que utilizaram uma placa não oclusiva (PNO), sem interferência na dimensão vertical de oclusão e na máxima intercuspidação habitual (MIH), com a idéia de exercer efeito placebo.

Através de um período de avaliação de 2 meses, distribuídos em intervalos de $7,15,30$ e 60 dias e análise estatística dos resultados, pôde-se concluir que o tratamento proposto e ambas as placas (PMRC e PNO), foram capazes de: 1) promover aumento médio da abertura bucal de 6,6 $\mathrm{mm}$ e 5,8 $\mathrm{mm}$, respectivamente, não sendo uma diferença estatisticamente significante entre os grupos; 2) restabelecer a amplitude do movimento lateral; 3) eliminar a dor/cansaço muscular em 84,6\% (PMRC) e 93,3\% (PNO) dos pacientes; 4) eliminar as dores de cabeça em 91,6\% (PMRC) e 84,6\% (PNO) dos pacientes; 5) contribuir para a redução ou eliminação dos sintomas dolorosos na região na nuca e pescoço em $75 \%$ (PMRC) e 83,3\% (PNO) dos pacientes; 6) reduzir ou eliminar as dores na 
região do ouvido em 92,3\% (PMRC) e 72,7\% (PNO) dos pacientes; 7) eliminar o estalido em 30\% (PMRC) e 46\% (PNO) dos pacientes; 8) eliminar ou reduzir os sintomas relacionados com os hábitos parafuncionais, independente de sua eliminação; 9) eliminar ou reduzir os sintomas que poderiam estar relacionados com os fatores oclusais; 10) modificar o grau de DCM para "DCM leve" ou "sem DCM", quando avaliado pelo índice anamnésico, em todos os pacientes do grupo PMRC e em 14 do grupo PNO; 11) reduzir em aproximadamente $30 \%$ o grau de tensão dos pacientes, avaliados por índice analógico.

Dois esquemas oclusais (guia canina e função em grupo) em relação à atividade muscular mastigatória foram investigados por AKOREN; KARAAGAÇLIOGLU², em 1995. O experimento foi realizado em 30 indivíduos, sendo 15 com guia pelo canino e 15 com função em grupo, através de registros eletromiográficos integrados bilaterais dos músculos masseter e temporal anterior obtidos por eletrodos de superfície durante a mastigação de chiclete e deslize lateral da relação cêntrica. Os resultados indicaram que não houve diferença estatisticamente significante entre os 2 esquemas oclusais. Entretanto, segundo o autor, além de o guia pelo canino mostrar uma menor atividade do músculo temporal anterior, durante 0 deslize lateral da posição de relação cêntrica, também mostrou ter um modelo mastigatório mais estreito com a mandíbula sendo dirigida verticalmente durante a mastigação, sugerindo, portanto que, na presença de dentes caninos saudáveis, a guia pelo canino deverá ser preferida. 
A resposta de indivíduos com deslocamento sem redução submetidos a três tipos de tratamento, foi avaliada por SATO; MOTEGI ${ }^{154}$, em 1995. Selecionaram-se 22 indivíduos para o tratamento com placa de estabilização, 24 indivíduos que não responderam ao tratamento não invasivo e necessitaram de cirurgia e 31 indivíduos que não receberam nenhuma forma de tratamento. Os autores verificaram uma taxa de sucesso no tratamento de $41,9 \%$ para o grupo controle, $55,0 \%$ para o grupo com placa estabilizadora e $76,9 \%$ para o grupo cirúrgico, não havendo, portanto, diferenças estatisticamente significativas entre os três grupos.

Cinco escalas diferentes de auto-avaliação para dor, em pacientes com desordens temporomandibulares, foram testadas por MAGNUSSON; LIST; HELKIMO ${ }^{107}$, em 1995. Assim, a precisão, a sensibilidade e a capacidade de registrar a memória da dor e o desconforto foram comparados para cada uma das cinco escalas. De acordo com os autores, a escala de avaliação do comportamento foi considerada superior às das quatro outras com respeito à precisão e à sensibilidade para a dor e desconforto. Essa escala foi também considerada pelos pacientes como sendo a mais relevante e a mais simples de se entender. Desses resultados, a escala de avaliação de comportamento pode ser recomendada quando da mensuração de dor e desconforto nos pacientes com desordens temporomandibulares.

Objetivando comparar os efeitos de um dispositivo interoclusal com função em grupo e pelo canino na atividade 
eletromiográfica do músculo masseter em indivíduos assintomáticos, BORROMEO et al. ${ }^{18}$, em 1995 , confeccionaram placas estabilizadoras com guia, posicionadas no arco superior, e, placas com função em grupo, posicionadas no arco inferior. A atividade eletromiográfica do músculo masseter foi, então, registrada durante o apertamento em oclusão cêntrica, durante os movimentos de lateralidade esquerda e direita em dez indivíduos assintomáticos. Os autores demonstraram que não houve diferença na atividade eletromiográfica do músculo masseter com o uso de ambos os aparelhos, uma vez que ambos reduziram, de maneira igual e significativa, a atividade eletromiográfica.

SELIGMAN; PULLINGER ${ }^{160}$, em 1995, analisaram a correlação de atrição de canino com a idade em 148 indivíduos assintomáticos, como também, o período de tempo necessário para registrar uma diferença estatisticamente significativa na atrição. Segundo os autores, a idade explicou $12,6 \%$ das diferenças nos índices de atrição total. Além disso, pelo menos 20 a 30 anos são necessários para demonstrar diferenças clínicas significativas com exceção das alterações de atrição laterotrusivas, que podem ser discriminadas em apenas 10 anos para o grupo de 20 a 29 anos. Não foram encontradas taxas de desgaste acelerada antes dos 20 anos na maior parte das áreas da dentição. Os autores concluíram que a atrição tem etiologia multifatorial, tendo a idade e a geometria do guia canino influência significativa, além da parafunção comumente aceita. 
Utilizando a escala ATM como medida da melhora dos sintomas WILLIS ${ }^{185}$, em 1995, verificou a efetividade do uso da placa com guia pelo canino com movimento lateral imediato no tratamento da disfunção temporomandibular. Para tal objetivo, utilizou 50 indivíduos com DTM no grupo experimental e 11 indivíduos no grupo controle. Para o grupo experimental foi utilizada uma placa com guia pelo canino de tal forma que seu movimento lateral fosse limitado pela alteração de seu desenho (ponta de canino alto). O autor concluiu que, pela melhora observada nos pacientes, o uso de placas estabilizadoras é uma excelente modalidade terapêutica no tratamento de pacientes com DTM e que, apesar dessa melhora, são necessárias novas pesquisas com diferentes desenhos e com um número maior de pacientes, antes que conclusões mais definitivas sejam alcançadas. Além disso, verificou que a escala ATM é um método excepcional para comparar a alteração dos sintomas nos pacientes, permitindo uma comparação da efetividade do tratamento.

VISSER; NAEIJE; HANSSON ${ }^{179}$, em 1995, fizeram uma avaliação eletromiográfica e clínica através de placas estabilizadoras com guia pelo canino a curto prazo ( 3 a 6 semanas) em pacientes com DTM miogênica. Para tal objetivo, utilizaram 35 pacientes com DTM. Os pacientes foram clinicamente examinados e foram feitos registros EMG de superfície dos músculos temporal e masseter durante apertamento em posição de intercuspidação máxima, imediatamente após a esplintagem e após 3 semanas de tratamento. Os autores observaram que um grupo demonstrou uma redução na atividade do músculo temporal durante o 
tratamento. Outro grupo não demonstrou qualquer alteração significante, e um terceiro grupo demonstrou um aumento de atividade do músculo temporal. De modo geral, foram encontradas reduções significantes na quantidade de dor estática. No grupo com uma redução significante da atividade do músculo temporal ( $n$ : 15) houve uma redução maior na quantidade de dor estática que no grupo (n: 4) com um aumento da atividade do músculo temporal. Os resultados podem indicar que o músculo temporal tem um papel importante na percepção da dor estática no sistema mastigatório.

Para este estudo WRIGHT; ANDERSON; SCHULTE ${ }^{191}$, em 1995, utilizaram 30 pacientes com dor nos músculos mastigatórios, nos quais placas resilientes e tratamento paliativo foram empregados. Os pacientes foram divididos igual e aleatoriamente em 3 grupos: 1) placa resiliente, entregue ao paciente para usá-la por 24 horas; 2) tratamento paliativo que consistia de instruções caseiras como: aplicação de frio ou quente, comer comidas leves, diminuir os hábitos parafuncionais, consumo de café, modificações de postura de dormir e medicação caso fosse necessário (dor aumentada); 3) este grupo não recebeu nem placa, nem tratamento paliativo. Os autores verificaram que no grupo com placa resiliente houve uma melhora estatisticamente significante nos sintomas; no grupo com tratamento paliativo houve uma melhora, mas não foi estatisticamente significante, e o grupo de não-tratamento teve uma leve agravação dos sintomas. 
Para verificar o efeito da placa oclusal sobre os diferentes parâmetros de curvas obtidas pelos traçados axiográficos das ATM, PICHSLINGER ${ }^{141}$, em 1995, utilizou, trinta e seis pacientes que foram axiografados antes e após a terapia com placas oclusais estabilizadoras, seguida da avaliação do efeito da terapia sobre os vários parâmetros de curvas da axiografia computadorizada. Os resultados obtidos para o grupo de pacientes tratados com placa foram comparados aos dados de 6 pacientes, também axiografados, mas deixados sem tratamento por um período de seis semanas antes de um segundo traçado para a articulação ser obtido. Os autores mostraram que a placa tem um certo efeito no estalido recíproco da ATM (resposta de 67\%). As trajetórias também foram melhoradas (44\%). Em contraste, os traçados das articulações no grupo controle permaneceram essencialmente sem mudanças.

Algumas considerações sobre a estabilidade oclusal dos dentes, foram realizadas por WISKOTT; BELSER ${ }^{188}$, em 1995, relatando que durante a posição de intercuspidação e mastigação as forças não só são direcionadas axialmente, como vetores de força horizontalmente, mas também estão presentes, ou seja, durante a função, os dentes são, na verdade, balanceados em várias direções. De acordo com os autores, as forças exercidas durante a mastigação não influenciarão necessariamente a posição dos dentes. Somente forças causadas pela erupção do dente e pelas pressões de repouso da língua e bochechas determinarão a estabilidade vestíbulo-lingual. Um contato por dente, para neutralizar as forças eruptivas (sob condições ideais), deverá estar localizado em uma 
fossa central, e contatos interproximais adequados (que atuam contra as fibras transeptais) determinarão a estabilidade do arco. Isso tudo estando o paciente com uma guia anterior correta, permitindo a desoclusão dos dentes posteriores durante os movimentos excursivos.

SIMMONS; GIBBS ${ }^{166}$, em 1995, investigaram se os discos da articulação temporomandibular podem ser recapturados a curto e a longo prazo pelo uso da placa de reposicionamento anterior, e se a recaptura do disco é necessária para o alívio do sintoma em uma disfunção temporomandibular. Foram verificados não só clinicamente como através de ressonância magnética 30 indivíduos que necessitavam de tratamento com placa de reposicionamento anterior, mas apenas 19 terminaram a fase I que durou uma média de 9 meses após a melhora dos sinais e sintomas de disfunção temporomandibular. Os autores verificaram que as placas de reposicionamento proporcionam alívio efetivo para indivíduos com dores fortes na ATM, e que elas recapturam o disco para posição de normalidade, apesar de esses resultados terem sido obtidos logo após o término da fase I. Contudo, a correlação entre esses dois resultados está longe da perfeição, isso porque, nesse estudo, a posição do disco não influenciou necessariamente a melhora dos sintomas, já que houve indivíduos com o disco na posição de normalidade e mesmo assim apresentaram sinais e sintomas de DTM; e, indivíduos que apresentaram o disco deslocado e relataram melhora substancial das dores na ATM. 
FERRARIO et al. ${ }^{52}$, em 1996, realizaram uma análise quantitativa dos movimentos de abertura e fechamento, nos movimentos limite laterotrusivos, em 165 indivíduos com um desvio lateral igual ou maior que $5 \mathrm{~mm}$, sem sintomas de DTM. Os movimentos foram diretamente realizados pelos indivíduos e registrados com um cinesiógrafo mandibular. A inclinação da guia lateral foi medida nos primeiros milímetros de movimento começando da posição de máxima intercuspidação. Os autores verificaram que: a) que todos os indivíduos mostraram grandes desvios mandibulares em relação à linha média durante o movimento de abertura máxima e que, o desvio mandibular nem sempre foi associado com estalido da ATM; b) uma associação foi vista entre o lado de látero-desvio na abertura máxima e uma guia laterotrusiva plana ipsilateral. Os autores concluíram que uma guia lateral plana não protege completamente a ATM ipsilateral (lado de trabalho) de estresse oclusal. Enfatiza assim, a importância das guias dentais nos movimentos mandibulares para a proteção da ATM e das superfícies oclusais.

A influência da discrepância oclusal experimental sobre a atividade dos músculos temporal anterior e posterior e o masseter em 12 indivíduos com dentição sadia, foi avaliada por BABA et al. ${ }^{6}$, em 1996. Confeccionaram-se interferências oclusais de resina e colocado sobre o canino superior e sobre o segundo molar inferior, tanto no lado de trabalho como no lado de balanceio e executadas tarefas de apertamento excêntrico. Os autores verificaram que, quando comparado com o apertamento na dentição natural inalterada, o apertamento nas interferências experimentais 
resultou em padrões distintos nos músculos elevadores da mandíbula, e a alteração mais característica foi observada quando o esforço de apertamento foi exercido na interferência experimental do lado de não trabalho. Observou-se, também, que a atividade eletromiográfica nos músculos temporais anterior e posterior foi diminuída no lado de trabalho e aumentada no lado de não trabalho, enquanto que os músculos masseteres não se alteraram. Segundo os autores, apesar de os músculos masseteres se contraírem bilateralmente, independentemente das alterações das condições, imagina-se que a atividade unilateral nos músculos temporais, quando a mandíbula é apoiada no lado de trabalho, previna a inclinação mandibular de alguma forma. Assim, as respostas dos músculos temporais à interferência do lado de não trabalho parecem desviar a mandíbula consideravelmente para superior, no lado de trabalho, e para inferior do lado de não-trabalho, e isso pode resultar em uma carga articular não moderada no lado de trabalho. Os autores, portanto, através dos resultados desse estudo, sugerem que a interferência de lado de não trabalho provoca uma atividade muscular específica, durante o apertamento parafuncional, e que o padrão de atividade resultante pode alterar a quantidade e direção das forças nas articulações temporomandibulares

DONEGAN; CHRISTENSEN; MCKAY ${ }^{45}$, em 1996, investigaram a presença da guia pelo canino e os estalidos de ATM em 46 indivíduos com disfunção de ATM e dos músculos, e 46 indivíduos saudáveis. Eles verificaram que, durante a laterotrusão para a direita e para a esquerda da mandíbula, o número de possibilidades de contato de guia foi 
quatro. Além disso, os autores examinaram as associações entre os estalidos das ATMs e os eventos de guia pelo canino (GP). Seus achados evidenciaram que: a) não-pacientes, o guia pelo canino foi relativamente infreqüente (30\%) e a ausência foi relativamente freqüente $(70 \%)$; b) em pacientes, a presença de guia pelo canino foi de $22 \%$ e a ausência foi de $78 \%$; c) em ambos os grupos, a presença de guia pelo canino bilateral foi de $15 \%$; d) em ambos os grupos com presença de estalidos na ATM, a presença de guia pelo canino foi de $38 \%$, enquanto que a ausência foi de $61 \%$.

LEIB $^{97}$, em 1996, relatou que a Odontologia, como todas as profissões da saúde, deve aceitar que o procedimento menos invasivo e mais reversível deve preceder à abordagem cirúrgica. Relata, ainda, que o diagnóstico precoce e a confecção de um aparelho oclusal reversível freqüentemente é o meio mais efetivo, rápido e menos invasivo na terapia de pacientes com DTM, já que elas permitem que as forças de carga sobre a ATM sejam reduzidas, favorecendo a reparação da mesma, e que tratamentos envolvendo a cirurgia da articulação temporomandibular, ajuste oclusal, cirurgia ortognática, ortodontia e outras devem ser consideradas apenas após a terapia com placa oclusal ter sido mal sucedida.

Com o objetivo de revisar os efeitos e taxas de sucesso dos vários aparelhos oclusais e fornecer ao profissional informações úteis para que pudessem orientá-lo na previsão do resultado e sucesso da terapia com as placas, MAJOR; NEBBE ${ }^{109}$, em 1997, realizaram uma revisão de 
literatura. Os autores concluíram que as placas oclusais são efetivas na redução da cefaléia, abertura mandibular e dor muscular e que têm um valor limitado na redução da dor articular, com exceção das placas de reposicionamento anterior.; b)a maior parte da literatura não sustenta a resolução do click como um objetivo válido na terapia com placa; c) a eletromiografia, como um instrumento clínico para medir a resposta de um indivíduo ao tratamento, não é válida e deve ser reservada para a pesquisa clínica; d) os achados relatados são mistos, mas a evidência geral sustenta que a desoclusão posterior reduz a atividade eletromiográfica e que a relevância clínica permanece controversa.

KURITA; KURASHINA; KOTANI ${ }^{93}$, em 1997, avaliaram 232 indivíduos portadores de dor crônica aos movimentos, ruído articular (com exceção de clique recíproco) e dificuldade de abertura bucal tratados com placa estabilizadora durante o período de 1987 a 1995 . Os autores verificaram uma taxa de $41 \%$ na remissão total dos problemas e $84 \%$ naqueles que relataram alguma melhora. A presença de alguns pacientes que possuíam deslocamento do disco reduziu significativamente a taxa de sucesso. Pelos resultados obtidos, os autores sugerem que a terapia com placa de estabilização pode ser uma modalidade de tratamento útil na terapia de desordens temporomandibulares, especialmente para pacientes sem evidência clínica de deslocamento de disco.

Tem sido sugerido que os aparelhos de estabilização e reposicionadores da mandíbula funcionam pela descompressão da 
articulação temporomandibular. Para testar indiretamente essa premissa, KUBOKI $^{91}$, em 1997, realizou tomografias das articulações temporomandibulares direitas de 7 pacientes, tiradas durante o fechamento confortável e o fechamento máximo em máxima intercuspidação nos dois tipos de aparelhos oclusais. Os contornos dos côndilos e das fossas temporais foram obtidos por um detector de contornos. O autor verificou que, no fechamento confortável, a dimensão do espaço articular anterior foi reduzida com os aparelhos de estabilização e os aparelhos reposicionadores anteriores da mandíbula. No fechamento máximo, a dimensão do espaço mínimo articular nos aparelhos de estabilização foi equivalente àquele visto em máxima intercuspidação, enquanto que nos aparelhos reposicionadores anteriores da mandíbula foi substancialmente menor. Os achados não indicam que estes aparelhos induzem a um aumento no espaço articular durante o fechamento.

Segundo $\mathrm{BECK}^{14}$, em 1997, os fatores que podem influenciar o efeito placebo são divididos em três categorias: fatores do paciente, do profissional e da situação. De acordo com o mesmo autor, um dos fatores mais importantes parece ser o nível de ansiedade ou stress no momento do tratamento. Os placebos são mais eficazes no alívio da dor pós-operatória, quando o nível de stress é maior. Além da ansiedade, estes são outros fatores agregados ao paciente: a expectativa, a antecipação do alívio, a experiência vivenciada pelo paciente com outros tratamentos, ou seja, se as experiências passadas dos pacientes incluem respostas favoráveis ao tratamento, a probabilidade de sua resposta ao placebo é 
aumentada. Além desses, outros fatores podem aumentar o efeito placebo: atitude positiva em relação ao paciente, em relação ao tratamento, atitudes do pessoal auxiliar, são fatores que podem determinar o aumento do efeito placebo.

Com o objetivo de determinar se a placa de estabilização é um tratamento adequado para a síndrome da dor disfunção e qual seria o melhor meio de sua utilização, DAVIES; GRAY44, em 1997, .utilizaram para isso, 70 pacientes com síndrome de dor e disfunção os quais usaram uma placa de estabilização por 3 meses e divididos em grupos. O grupo 1 (23 pacientes) utilizou placa por 24 horas/dia; o grupo 2 (19 pacientes) utilizou a placa apenas durante o dia; o grupo 3 (28 pacientes), apenas à noite. Os autores verificaram que não houve vantagem estatisticamente significante de qualquer padrão de utilização da placa, com todos os grupos demonstrando uma melhora acentuada tanto pela avaliação objetiva como subjetiva. Assim, os autores estabeleceram que o melhor uso da placa seria somente à noite.

CANAY $^{26}$, em 1998, comparou a efetividade da terapia com placa na atividade eletromiográfica dos músculos temporal anterior e masseter, antes e depois da aplicação de uma placa de relaxamento muscular, em quatorze indivíduos com dor nos músculos mastigatórios. Os registros da eletromiografia foram analisados quantitativamente durante o apertamento máximo, na posição de intercuspidação, antes como depois do tratamento (6 semanas). Os resultados do estudo revelaram que: 1) a 
atividade eletromiográfica dos dois músculos durante a mordida máxima não foi notadamente mudada depois que a placa de relaxamento muscular foi usada; 2) as mudanças observadas na atividade eletromiográfica dos lados envolvidos e não envolvidos também foram insignificantes.

DAO; LAVIGNE$^{42}$, em 1998, relataram que apesar da prescrição aproximadamente universal das placas oclusais no tratamento das DTM, ou bruxismo, a qualidade das evidências que apóiam os mecanismos de ação sugeridos para sua presumida eficácia são ainda questionáveis. Para os autores, embora a perspectiva para a cura da DTM e/ou bruxismo, ou tentativa de eliminar suas causas desconhecidas permaneçam uma expectativa não realística, ainda pode ser argumentado que a melhora da percepção do paciente no seu bem-estar, ou uma mudança de seus hábitos prejudiciais através da utilização criteriosa de uma estratégia de tratamento não invasivo e custo eficiente (tais como o uso de placas estabilizadoras), podem representar uma alternativa aceitável. Segundo os mesmo autores, se reconhecermos que as melhoras aparentes observadas na maioria dos estudos de placas orais puderem ser devidas a efeitos não específicos de tratamento, isto é, placebo, relação profissional/paciente, ou a evolução cíclica natural da condição, então devemos concluir que as placas orais podem ser usadas somente como um auxiliar no tratamento da dor das DTMs, até a história natural e etiologia das DTMs serem elucidadas, e tratamentos mais específicos paras estas condições serem desenvolvidas. 
O desgaste posterior nas superfícies oclusais das placas de estabilização, em cinco indivíduos com bruxismo noturno, foram verificadas por KORIOTH et al. ${ }^{89}$, em 1998. Essa verificação foi efetuada através de moldagem dos padrões de desgaste realizados 2 semanas após a entrega dos aparelhos e, subseqüentemente, no terceiro mês de uso, e avaliadas por um programa de computador. O desgaste foi quantificado pela mensuração de profundidade e volume do material perdido de acordo com o contato do dente antagonista. Os resultados mostraram diferenças significantes com relação aos padrões de profundidade de desgaste entre os lados, direito e esquerdo, indicando que aquele foi mais profundo na área de segundo molar do lado direito e localizado no canino do lado esquerdo. Contudo, em ambos os lados, o padrão mostrou os menores valores, no segundo pré-molar. Essa tendência não foi evidente para o desgaste em volume, o qual foi maior no canino do lado esquerdo, sendo similar para todas as regiões de contato no lado direito. Os autores verificaram que os padrões desiguais de desgaste, entre as diferentes localidades na placa, provavelmente refletem o efeito combinado de muitas variáveis biomecânicas. Já que era esperado o canino apresentar maior quantidade de desgaste, devido ao desenho do aparelho, os achados de alta magnitude de desgaste nos dentes posteriores foram imprevistos porque as placas foram submetidas ao ajuste clínico cuidadoso antes da coleta dos dados a fim de se criarem contatos bilaterais e simultâneos. Portanto, os autores concluem que se a profundidade de desgaste é um reflexo de transmissão da força mastigatória, então, os resultados desse estudo corroboram a natureza dinâmica da flutuação de 
carga dentro do sistema na presença de contatos oclusais uniformes e bem distribuídos.

A eficácia, em curto prazo, de um aparelho de estabilização em 60 indivíduos com DTM de origem artrogênica, utilizando um projeto aleatório, controlado e duplo-cego, foi avaliada por EKBERG; VALLON; NILNER ${ }^{49}$, em 1998 Os indivíduos foram distribuídos igualmente em dois grupos: o experimental, que recebeu uma placa estabilizadora, e o controle, que recebeu uma placa não oclusiva. Os autores relataram que houve uma melhora dos sintomas subjetivos totais, em ambos os grupos, mais significativamente com mais freqüência no grupo de tratamento do que no grupo controle. A freqüência da dor diária ou constante demonstrou uma redução significativa no grupo de tratamento com relação ao grupo controle. As dores na ATM, tanto em repouso como em movimento, diminuíram significativamente nos dois grupos. Portanto, os resultados dessa avaliação, em curto prazo, demonstraram que ambos os aparelhos tiveram um efeito sobre a dor na articulação temporomandibular, e que é improvável que a diferença observada entre os grupos seja somente casual.

Os efeitos em curto prazo dos aparelhos de estabilização na atividade parafuncional noturna, em 14 indivíduos com bruxismo e sinais e sintomas de desordem da articulação temporomandibular, foram estudadas por $\mathrm{YAP}^{193}$, em 1998. O autor verificou a presença de facetas ativas nas superfícies dos aparelhos oclusais, em ambos os grupos em cada visita. Embora as facetas aparecessem, aproximadamente, no mesmo lugar, foram 
maiores em área. Além disso, o exame das rampas guia indicou que $29 \%$ dos indivíduos sem DTM e em $21 \%$ dos indivíduos com DTM houve ausência de face de desgaste, e que, em ambos os grupos, todos os indivíduos que eram bruxistas noturnos tinham facetas de desgaste nas rampas bilaterais em cada visita. O autor também verificou que a placa não parou o bruxismo, tanto nos indivíduos com ou sem DTM.

OGAWA; OGIMOTO; KOYANO ${ }^{131}$, em 1998, não só verificaram que tipo de contato oclusal existiria nas diversas excursões mandibulares, como também avaliaram a validade da proteção do canino e função em grupo como categorias na classificação dos padrões de guia oclusal na dentição natural. Segundo os autores, o conceito de proteção pelo canino e função em grupo necessitam de consistência nas definições e nos métodos de exame. Para tal objetivo, os contatos oclusais de 86 indivíduos foram examinados com shim stock nas posições laterais a 0,5; 1,2 e $3 \mathrm{~mm}$ da intercuspidação máxima. De acordo com os autores, a maioria dos padrões de contato pertenceram à função em grupo e poucos à proteção pelo canino, isso focalizando somente os contatos do lado do trabalho. Focalizando os contatos do lado de trabalho e do lado de nãotrabalho, aproximadamente metade dos padrões de contato era diferente da proteção pelo canino e função em grupo, e foram classificados como oclusão balanceada. Portanto, os autores concluíram que o atual sistema de classificação de guia oclusal é questionável e que uma nova classificação poderia ser feita. 
A efetividade da terapia com placa na atividade eletromiográfica dos músculos mastigatórios (temporal anterior e masseter), antes e depois da colocação de uma placa de relaxamento muscular, em 14 pacientes com dor facial, foi comparada por CANAY et al. ${ }^{26}$, em 1998.. Para isso, registros de eletromiografia dos músculos temporal anterior e masseter foram analisados quantitativamente durante a mordida máxima na posição de intercuspidação, antes e depois do tratamento de seis semanas, sem a placa. Os autores concluíram que a atividade eletromiográfica dos dois músculos, durante a mordida máxima não foi notavelmente mudada depois que a placa oclusal foi usada, como também não houve diferença estatisticamente significante entre o lado envolvido e o não envolvido.

LUNDH et al. ${ }^{103}$ em 1985, compararam, a placa de reposicionamento anterior com a placa oclusal plana e um grupo controle, no tratamento das articulações temporomandibulares, em 70 indivíduos. A esplintagem de reposicionamento anterior é amplamente utilizada para tratar articulações temporomandibulares com clique recíproco. Esse tratamento foi comparado a uma esplintagem oclusal plana e a um grupo controle não tratado. Os autores verificaram que a placa de reposicionamento anterior diminuiu a dor articular em repouso, durante a mastigação e durante a protrusão. O clique recíproco foi eliminado e a sensibilidade da articulação e músculos à palpação foi reduzida. Esse efeito favorável foi de curta duração. A maioria dos pacientes relatou dor e clique e demonstrou sensibilidade após a remoção da esplintagem, após 6 semanas de tratamento. A esplintagem oclusal plana diminuiu a sensibilidade articular, mas não afetou 
o clique ou a sensibilidade muscular. No grupo controle, o clique permaneceu e a freqüência de sensibilidade muscular aumentou. Os resultados indicam que as articulações temporomandibulares com clique recíproco podem ser tratadas com sucesso pelo posicionamento anterior da mandíbula. Para os autores, uma vez que os sintomas retornaram quando a esplintagem foi removida, uma alteração mais permanente da posição mandibular parece necessária.

SANTACATTERINA ${ }^{151}$, em 1998, revisaram a literatura de 1985 a 1996 com relação ao tratamento de deslocamento do disco com redução. Por meio de um estudo de meta-análise comparou a efetividade de dois tipos de placa: reposicionamento anterior e placa de estabilização. Para tal estudo, foi selecionada uma amostra de seis estudos, divididos em dois grupos: estudos comparando a placa de reposicionamento e a placa de estabilização; e grupo 2, em que estudos envolviam apenas a placa de reposicionamento. A meta-análise da literatura, sobre esse assunto, demonstrou excelentes resultados obtidos com a placa de reposicionamento contra os principais sintomas de deslocamento do disco: ruído articular e dor, bem como o fato de ser mais efetiva quando comparada à placa de estabilização.

A prevalência da relação entre os molares, guia oclusal (canino e função em grupo) e os contatos de lado de não-trabalho, em 263 indivíduos com desarranjo intra-articular e 82 indivíduos assintomáticos, foi comparada por KAHAN et al. ${ }^{84}$, em 1999, Em todos os participantes do 
estudo foi feita a ressonância magnética para avaliar a presença ou ausência de deslocamento de disco, sendo então divididos em 4 grupos: 1) assintomáticos sem desarranjo; 2) assintomáticos com desarranjo; 3) sintomáticos sem desarranjo e 4) sintomáticos com desarranjo. Os autores verificaram que: a) o relacionamento oclusal mais prevalente foi a Classe I e no grupo sintomático houve um aumento na prevalência de Classe II, divisão I, mas a força geral dessa relação foi fraca; b) houve uma predominância da função em grupo em ambos os lados, direito e esquerdo, dos indivíduos assintomáticos. Já no lado direito, houve um aumento significante na prevalência da guia pelo canino no grupo sintomático com deslocamento do disco; c) os grupos dos indivíduos sintomáticos com e sem deslocamento tinham significativamente menor quantidade de contatos no lado de nãotrabalho se comparados com os indivíduos assintomáticos que tinham uma alta prevalência de um ou mais contatos no lado de não-trabalho.

O efeito da espessura das placas protetoras sobre 0 bruxismo noturno, foi verificado por DRAGO; RUGH; BARGHI ${ }^{46}$, em 1999. Os autores utilizaram, para tal propósito, seis pacientes bruxômanos noturnos com um conjunto de 3 placas colocadas na maxila, com uma espessura vertical na região incisal de 2, 4 e $6 \mathrm{~mm}$. Foi dito aos indivíduos que alternassem o uso dos aparelhos de uma maneira cíclica por um período de 6 a 10 semanas. A cada quarta noite, nenhuma placa foi utilizada. Os registros cumulativos eletromiográficos da atividade unilateral do masseter eram feitos à noite, com uma unidade portátil de eletromiografia, na casa de cada paciente. Os autores verificaram diferenças 
muito claras nos níveis de atividade EMG noturna com placas de diferentes espessuras. Em três indivíduos, a espessura de $6 \mathrm{~mm}$ forneceu a atividade mais baixa de EMG. A de espessura $2 \mathrm{~mm}$ forneceu atividade mais baixa em dois indivíduos, e a de $4 \mathrm{~mm}$ pareceu ideal para o sexto indivíduo. Esses resultados sugerem que a espessura vertical da placa pode ser um fator importante que influencia a efetividade. Além disso, contrária à opinião clínica, a placa mais fina não é necessariamente a ideal.

De acordo com CAPP $^{27}$, em 1999, as placas oclusais podem ser utilizadas para a prevenção da perda de superfície dentária, tratamento das desordens temporomandibulares, estabilização pré-restauradora, criação de espaço para restaurar dentes anteriores desgastados e proteção de novas restaurações da parafunção. Segundo o autor, pacientes afetados por perda de superfície dentária necessitam de abordagem protetora. Onde as cargas sobre os dentes são altas, uma placa oclusal pode ser uma forma muito efetiva de limitar um desgaste adicional. Se estratégias preventivas não forem introduzidas, a dentição poderá ficar muito desgastada e restaurações fixas, impossíveis de serem feitas.

De acordo com WIDMALM ${ }^{182}$, em 1999, é comum o erro de deixar o tratamento com placa de mordida se estender por anos sem que seja feito um encaminhamento apropriado. Se os problemas agudos dos pacientes não se resolverem dentro de poucos meses, ou as condições não estivem ao menos melhorando, o dentista deve verificar se está faltando algo no diagnóstico ou no plano de tratamento. Ainda, segundo o autor, 
alguns indivíduos se adaptam bem às placas, mas reclamam que se pararem de usá-las, os sintomas voltam. O dentista tem a obrigação de tentar resolver o problema do paciente com tratamentos alternativos e através de encaminhamentos apropriados. O autor conclui que os dentistas devem se proteger e a seus pacientes, através da seguinte conduta: 1) fazendo moldes de estudo e tirando fotografias da dentição antes de começar o tratamento; 2) fazendo exames apropriados e registrá-los nas fichas clínicas; 3) fornecer aos pacientes informações verbais e escritas do caso; 4) obter do paciente um consentimento assinado, dando-lhe uma cópia para que seja guardada.

Para demonstrar a atividade eletromiográfica dos músculos temporal e masseter, GRUBWIESER et al. ${ }^{68}$, em 1999, utilizaram 16 pacientes com prótese total frente ao uso da placa com guia pelo canino e oclusão balanceada bilateral. Os testes foram obtidos durante o contato de intercuspidação máxima, movimento protrusivo e excursões laterais da mandíbula. Os autores concluíram que em pacientes edêntulos devem ser aplicados os mesmos princípios gnatológicos daqueles utilizados em pessoas com dentição natural. Isso porque o estudo evidencia que as atividades musculares com guia anterior, em relação à oclusão balanceada bilateral, demonstraram valores significantemente mais baixos, tanto no movimento protrusivo como nas excursões laterais da mandíbula. Além disso, os autores concluíram que o uso de próteses, anteriormente guiadas, pode auxiliar a evitar o desenvolvimento de disfução craniomandibular, 
atividade muscular patologicamente aumentada com dor muscular, e também, reduzir pontos dolorosos e reabsorção de rebordo.

EKBERG; NILNER ${ }^{48}$, em 1999, investigaram se as diferenças nos resultados de tratamento entre pacientes que receberam uma placa estabilizadora e uma placa não oclusiva deveram-se ao tratamento e/ou a outros fatores em pacientes com desordens temporomandibulares (DTM) de origem artrogênica. Para tal objetivo, 60 pacientes foram igualmente divididos em 2 grupos: placa estabilizadora e um grupo controle, utilizando uma placa confeccionada em resina acrílica adaptada com grampos que não interferiam com a oclusão. Para avaliação, treze possíveis variáveis para o tratamento foram correlacionadas às alterações na severidade da dor na ATM, marcadas em uma escala verbal em ambos os grupos de pacientes. Os autores encontraram que a placa de estabilização foi um fator para explicar o resultado positivo do tratamento comparado aos pacientes do grupo controle.

Segundo SPEAR ${ }^{170}$, em 2000, existem dois mecanismos primários que podem ser alterados para o controle da força no tratamento oclusal: contração dos músculos da mastigação e distribuição da força. De acordo com o autor, os músculos da mastigação geram forças que criam problemas traumáticos. Caso, pela alteração dos contatos dentários, a contratibilidade dos músculos puder ser aumentada ou diminuída, a força total que incidirá no sistema será também aumentada ou diminuída. Qualquer contração muscular determinada no sistema mastigatório é 
distribuída entre a ATM, o periodonto e as superfícies oclusais dos dentes. Ainda, segundo o mesmo autor, a mandíbula funciona, em termos físicos, como um sistema de alavanca classe III, em que à medida que o braço da alavanca, que vai desde a ATM até o ponto de contato dentário, é aumentado, a força aplicada aos dentes é reduzida. Assim, os dentes posteriores, com seu braço de alavanca mais curto, recebem forças significantemente maiores do que os dentes anteriores. O mesmo ocorre com a ATM, utilizando o mesmo princípio da alavanca classe III, ou seja, à medida que o ponto de contato dentário é movido anteriormente, a quantidade de força gerada nos dentes é reduzida, mas na ATM é aumentada. Portanto, pode-se escolher se a maior parte da força de contração será absorvida pelos dentes, pela articulação ou, de certo modo, equilibrado entre ambos (o que ocorre na maior parte do tempo). Assim, quanto mais intenso forem os contatos nos molares, maior será a carga na região dos molares e menor será na da articulação. Com contatos menos intensos na região dos molares, as forças sobre os dentes serão reduzidas e desviadas para anterior, mas a intensidade da carga na ATM será aumentada. O autor concluiu que o mesmo fundamento poderá ser aplicado aos movimentos excursivos, ou seja, do mesmo modo que a guia pelo canino resultou em redução na atividade muscular, também resultará em uma redução na força aplicada sobre os dentes, simplesmente porque os dentes anteriores possuem um braço da alavanca muito mais longo em relação à articulação do que possuem os molares. 
Segundo SPEAR ${ }^{170}$, em 2000, naqueles pacientes em que já se esgotaram todas as formas de tratamento conservador, e em que o processo patológico na articulação ainda persiste produzindo dor como efeito colateral, o profissional irá deparar-se com a possibilidade do uso da oclusão para alterar os sintomas de dor, de algum modo, melhorando ao máximo o bem estar do paciente, mesmo se a articulação ficar abaixo da ideal. Assim, o único método real para alterar as cargas que incidem sobre esta articulação é aumentar a intensidade dos contatos na região posterior da boca, em especial na região de primeiros e segundos molares, de modo que existam contatos um pouco menos pesados nos pré-molares, e bem mais leves na região anterior, quase não tocando. Isso tem o intuito de proteger o ponto mais fraco do sistema mastigatório (nesse caso, a ATM) direcionando, assim, a tensão para aquelas áreas cuja saúde ainda continua em perfeitas condições: periodonto e dentes. Ainda, de acordo com o autor, antes de decidir por uma guia pelo canino, por sua capacidade de inibir a contração muscular, o profissional terá que testar esse padrão de desoclusão para saber se esse seria o esquema oclusal ideal, já que esse tipo de guia, apesar de inibir a contração, aumenta a quantidade da força na ATM do lado do trabalho, a qual já se encontra bastante debilitado. Caso o paciente esteja sentindo dor na região da articulação durante um movimento ao lado do trabalho, e essa dor for semelhante àquela sentida quando a mandíbula é colocada em posição superior durante a manipulação, os contatos dentais precisarão ser movidos para uma posição mais posterior, ou seja, de uma guia pelo canino para função em grupo. Se for possível 
levar os contatos em função de grupo para a região pré-molar e as dores pararem, essa manobra seria o suficiente. Mas, se as dores persistirem durante o movimento do lado de trabalho, os contatos em função de grupo deverão ser movidos, também, para a região dos molares, para alterar, de maneira eficaz, a carga sobre a articulação no lado de trabalho.

De acordo com MAH et al. ${ }^{108}$, em 2000, para o estudo da função mecânica do sistema mastigatório, com o objetivo de determinar as relações entre as forças que atuam entre os seus diversos componentes, foram criados diversos modelos físicos e matemáticos. Esses modelos têm o objetivo de simular o sistema mastigatório como um todo e verificando como as cargas musculares e a articulação respondem às variações na morfologia, magnitude da carga oclusal e posicionamento. Os autores concluíram que, embora os modelos atuais ainda sejam imperfeitos, a combinação de modelos físicos e matemáticos tem levado a novas introspecções da função da ATM. Além disso, esses modelos têm demonstrado que: a) o sistema mastigatório possui um amplo grau de flexibilidade, capaz de produzir forças oclusais intensas acopladas com forças reacionais articulares estáveis; b) as articulações do lado de balanceio recebem cargas maiores do que as do lado de trabalho durante a oclusão unilateral; c) as forças oclusais maiores são geradas por oclusões localizadas mais posteriormente, enquanto reduzem simultaneamente as cargas articulares totais. 
MIRANDA $^{122}$, em 2000, avaliou a efetividade das placas oclusais reposicionadoras no controle de patologias intra-articulares da ATM, quando comparadas a um tratamento convencional (placa estabilizadora) e um grupo sem tratamento (controle).

A amostra contou de 52 pacientes portaodres de sinais e sintomas de desordens intra-articulares da ATM, divididos, aleatoriamente em três grupos, de acordo com o procedimento empregado: grupo I ( $n=20)$, utilizou placa estabilizadora, grupo II $(n=18)$ utilizou placa reposicionadora e grupo III $(n=14)$, sem nenhum tratamento.

Toda a amostra foi acompanhada durante um ano, sendo avaliada através de questionários anamnésicos, palpação muscular e da ATM, movimentação mandibular e detecção de sons articulares.

Uma avaliação da condição oclusal também foi realizada nos diferentes períodos de exame.

Os resultados demonstraram uma maior efetividade das placas reposicionadoras na redução inicial da dor relatada pelo paciente, assim como uma diminuição na sensibilidade a palpação na ATM.

Todos os grupos mostraram-se semelhantes após seis meses de controle em relação aos sintomas, assim como em relação aos ruídos articulares. Os índices de palpação muscular mostraram-se melhor para todos os grupos, sendo que a oclusão também não se alterou significantemente. 
MARKLUND; VALNMAN ${ }^{115}$, em 2000, realizaram um estudo de revisão de literatura sobre a atuação dos contatos no lado de balanceio em relação à saúde do sistema estomatognático. Os autores observaram que não existe evidência científica suportanto a oclusão balanceada em favor da oclusão mutuamente protegida e vice-versa.

O efeito do uso das placas intra-orais nas proteoglicanas do disco articular da ATM foi verificada por SINDELAR et al. ${ }^{168}$, em 2000. Para tal objetivo, examinou as proteoglicanas do disco articular de 16 porcos fêmeas que foram divididos em 3 grupos, conforme as placas a que eram submetidas: 1) controle; 2) placa estabilizadora; 3) placa de reposicionamento. O período de uso das placas foi de 2 meses. O conteúdo das proteoglicanas em vários locais do disco foi determinado por ensaio colorimétrico. O autor constatou que o alto conteúdo e síntese de proteoglicanas, visto na parte intermediária do disco independente do grupo, suporta a hipótese de que essa zona engloba a maioria do carregamento compressivo pesado durante a função, e que as articulações dos animais de ambos os grupos que usaram a placa mostraram uma alta freqüência de graves patologias. Os achados sugerem que o uso de placa intra-oral pode causar danos ou remodelamento.

O efeito da terapia com placa de estabilização na força oclusal em seis mulheres com desordens dos músculos mastigatórios, foi avaliado por KURITA; IKEDA; KURASHINA ${ }^{92}$, em 2000. Para isso, os pontos oclusais e a carga no arco dental em apertamento máximo foram medidos 
usando-se um sistema computadorizado com Dental Prescale antes e duas semanas depois e quatro semanas depois da inserção de uma placa estabilizadora. Os autores verificaram que as placas de estabilização têm o efeito de normalizar a carga oclusal integrada, ou seja, após 4 semanas depois do uso da placa, as cargas oclusais chegaram perto da média de indivíduos saudáveis, que foi cerca de 191,4 $\pm 133,5 \mathrm{~N}$. Portanto, os autores sugerem que o uso de placa tem o efeito de reduzir a hiperatividade e a assimetria na atividade dos músculos elevadores mandibulares e, conseqüentemente, restabelecer uma força oclusal ótima e fisiologicamente estável.

Os critérios empregados para classificar uma oclusão como morfológica ou funcionalmente inaceitável, conforme STOHLER ${ }^{172}$, em 2000, pode incluir características como: interferências em cêntrica, no lado de trabalho, de balanceio e em protrusiva; "grande" deslizamento em cêntrica, sobremordida "profunda"; sobressalência "acentuada"; guia canina ausente; plano oclusal "irregular"; mordida cruzada anterior, dentes ausentes, facetas de desgaste, dimensão vertical "insuficiente" e "desequilíbrio" oclusomúsculos devido à falta de concentricidade côndilo-fossa ou à assimetria facial. Segundo o mesmo autor, nenhum estudo demonstra que qualquer uma dessas condições aumenta a probabilidde de sintomas associados com a disfunção temporomandibular (DTM) em um fator de 1000, 100 ou até mesmo 10. Concluiu o autor que é difícil encontrar uma oclusão natural que seja livre de, pelo menos, uma dessas características. 
Quarenta e cinco indivíduos adultos com oclusão em perfeitas condições foram utilizados por KORIOTH ${ }^{88}$, em 2000, para uma análise dos contatos oclusais no movimento mandibular do lado de trabalho. Nesta investigação, os contatos foram detectados nos deslocamentos mandibulares efetuados de 1,5 e $3 \mathrm{~mm}$, medidos a partir dos incisivos centrais. $\quad O$ autor verificou que a grande maioria dos indivíduos apresentaram padrões de contato que não estavam classificados de acordo com classificação tradicionalmente e dos esquemas oclusais conhecidos. $\mathrm{O}$ que mais se detectou no lado esquerdo de trabalho foi o guia pelo canino, e, no lado direito, a função em grupo. Segundo os autores, já que os indivíduos no período desse estudo não manifestaram sinais clínicos ou sintomas de DTM, parece que a categoria "interferência no lado de trabalho" deveria de fato ser classificada com "contato posterior no lado de trabalho".

Segundo $\mathrm{GEAR}^{55}$, em 2000, apesar de o tratamento com o uso de placas de mordida anterior, por poucas horas, em pacientes com dor nos músculos elevadores da mandíbula ter resultado satisfatório pela inibição da mesma, através da ativação dos mecano-receptores do ligamento periodontal dos dentes que estão em contato com a placa, esses aparelhos não devem ser usados durante a noite, mesmo se a dor for considerada resultante do bruxismo noturno. Isso porque o reflexo de inibição dos músculos elevadores da mandíbula parece ser diminuído durante o sono, e os pacientes são capazes de aplicar forças significativas de elevação mandibular (até mesmo se estiverem ocluindo apenas um ou dois dentes), expondo as ATMs a forças a cargas indesejáveis que podem 
causar lesões. Conclui o autor que a perda do contato oclusal posterior poderia efetivamente colocar as ATMs em desvantagem mecânica no braço de alavanca, criado pela colocação de um ponto de fulcro nos incisivos, exacerbando, assim, qualquer tipo de problema de ATM, seja dor ou instabilidade do disco.

Para melhor compreender como as alterações nos padrões de contato oclusal pelos aparelhos de resina podem influenciar a distribuição das cargas condilares, KORIOTH ${ }^{88}$, em 2000, fez uma simulação com o sistema mandibular por meio do uso de um computador, analisando a sua atuação mecânica através da técnica de confecção de modelos com elementos finitos. Para tal objetivo, o autor incorpora um aparelho de resina com recobrimento total das superfícies oclusais dos dentes superiores ao modelo, pesquisando o efeito do suporte molar em resina no lado de nãotrabalho sobre a magnitude das cargas condilares. Essa análise foi feita em três situações: na posição de intercuspidação, durante esforço excêntrico, em lateralidade esquerda e esforço excêntrico em lateralidade à esquerda, associado com contato no lado de não-trabalho. Quando as últimas duas tarefas foram comparadas, as previsões do modelo demonstraram claramente que a inclusão do suporte em resina sobre o segundo molar, no lado de não-trabalho, pode reduzir a carga no côndilo de não-trabalho. Segundo o autor, essas simulações sugeriram que a resina absorve as tensões nos locais de contato dentário reduzindo, assim, as cargas condilares gerais, quando comparadas com as atividades oclusais, sem o recobrimento de resina. Também indicaram que a inclusão do suporte molar 
(no lado de não-trabalho), transversalmente na arcada pelo aparelho de resina durante a oclusão excêntrica em lateralidade (lado do trabalho), pode ser vantajosa caso o objetivo seja reduzir as cargas articulares no lado de não-trabalho da ATM. Essa proposição, contudo, deve ser submetida a testes clínicos cuidadosos, antes de ser considerada válida.

De acordo com STOHLER ${ }^{172}$, em 2000, para que uma vantagem biológica possa ser associada com aparelho interoclusal, é considerado que tal efeito deva ser mediado por alterações nas cargas articulares, estabilidade articular e função muscular. Segundo o autor, contrariamente ao pensamento prevalecente em Odontologia clínica, as cargas articulares parecem ser um fator essencial para a manutenção das superfícies articulares intactas; a imobilização, redução das cargas e ausência de cargas produzem efeitos desastrosos e possivelmente irreversíveis. A partir desse ponto de vista, a validade do conceito de retirada de todas as cargas articulares é suspeita. STOHLER afirma que, na presença de pressão intra-articular aumentada, a introdução da placa oclusal pode impedir a ruptura da sinóvia durante a oclusão forçada. Além disso, pouco conhecimento está disponível sobre a biomecânica da ATM e a resposta de sua cápsula e ligamentos a uma ampla variedade de estímulos e tratamentos. Se houver, dados limitados atribuem vantagem biológica aos aparelhos reposicionadores. Além disso, uma vez que a redução da dor muscular mastigatória não é limitada exclusivamente aos casos com um aparelho interoclusal que, presumivelmente, romperia as informações dos contatos dentários nocivos, efeitos inespecíficos, tais como a expectativa do 
paciente em receber benefícios do tratamento, têm de explicar a resposta favorável do tratamento.

A influência da alteração dos padrões de contato dental no deslocamento mandibular durante o apertamento submáximo controlado em 12 indivíduos foi estudada por BABA et al. ${ }^{7}$ em 2001. Dispositivos oclusais de resina foram fabricados para o canino inferior do lado de trabalho, segundo molar do lado de trabalho e segundo molar do lado de balanceio para simular um guia canino dominante, interferência do lado de trabalho (IT), interferência do lado de balanceio (IB) e oclusão bilateral balanceada (BB) colocando-se os três dispositivos ao mesmo tempo. Deslocamentos verticais da mandíbula foram registrados por transformadores de variável diferencial linear durante o apertamento submáximo na posição lateral. $\mathrm{O}$ nível de apertamento foi controlado com auxílio do feedback visual da EMG dos músculos masseter e temporal. Os autores verificaram que durante o apertamento no canino direito com o dispositivo colocado, a mandíbula foi elevada com o menor deslocamento no pré-molar direito e com maior deslocamento no segundo molar esquerdo causando, assim, grandes elevações contralaterais. O mesmo ocorreu com a interferência no lado de trabalho. Os autores, então, concluíram que esse fato sugere grande carga compressiva na articulação temporomandibular do lado de balanceio. Já o apertamento na interferência do lado de balanceio resultou em um padrão de deslocamento mandibular com a maior elevação no lado de trabalho. Além disso, a amplitude da elevação do segundo molar, nesse mesmo lado, foi considerada como a maior entre as quatro condições simuladas. Os autores 
consideraram que esses achados sugerem que a articulação do lado de trabalho sofre uma grande carga compressiva. Já a oclusão bilateral simulada resultou na menor inclinação da mandíbula, quando comparada a outras condições experimentais.

Objetivando a avaliação do efeito dos aparelhos interoclusais sobre as articulações temporomandibulares por imagem de ressonância magnética e reconstrução em 3D, CHU et al. ${ }^{34}$ em 2001, realizaram ressonâncias magnéticas das ATM de 8 indivíduos, utilizando uma placa oclusal instalada, mantendo uma distância interincisal de $3 \mathrm{~mm}$, enquanto outro grupo (4) possuía suas placas mantendo uma distância incisal de $5 \mathrm{~mm}$. A reconstrução tridimensional foi realizada em um computador. As imagens tridimensionais permitiram a visualização dos relacionamentos articulares. Os autores verificaram que, com as placas de 5 mm, as mudanças nas relações côndilo-disco e côndilo/fossa eram mais variáveis.

KREINER; BETANCOR; CLARK ${ }^{90}$, em 2001, verificaram se existe evidência suficiente para julgar se aparelhos oclusais são eficientes no tratamento da mialgia mastigatória localizada, artralgia ou ambos, como também se esses aperelhos tinham alguma influência no comportamento do apertamento ou bruxismo. Os autores avaliaram quatro estudos controlados por placebo, vários estudos controlados com lista de espera escolhidos aleatoriamente e outros estudos na comparação de seu tratamento, concluindo que o efeito de tratamento sobre o nível dos sintomas naqueles 
estudos que utilizaram aparelhos oclusais foi melhor que o da ausência de tratamento em uma condição de grupo controle em lista de espera. Por outro lado, os estudos que utilizaram ao grupo placebo, como placas não oclusivas, comparados a estudos com aparelhos oclusais (estabilizadora) geraram mistura de informações: dois demonstraram um benefício positivo dos aparelhos oclusais com relação aos sem oclusão, e dois demonstraram um efeito nulo ou ausência de diferença. Considerando-se todas as informações disponíveis (prós e contras), os autores concluem que a utilização dos aparelhos oclusais no tratamento de mialgia mastigatória localizada, artralgia ou ambos, é suficientemente sustentada pela evidência na literatura e que o mecanismo de ação, pelo qual os aparelhos oclusais afetam a mialgia e artralgia localizada, provavelmente é a modificação comportamental do apertamento mandibular.

GREY; DAVIES, em 2001, relataram que todas as placas oclusais têm um efeito de ação semelhante: todas não só reduzem as forças oclusais, como têm um efeito placebo e alteram os contatos oclusais. Além disso, podem ser utilizadas no tratamento da dor facial, muscular, temporomandibular, dos ruídos articulares e para estabilizar a posição mandibular. Os autores relatam, também, que um benefício importante na terapia com placa oclusal é que, se o tratamento for mal sucedido, a placa poderá ser descartada, deixando o profissional seguro ao saber que não foram feitas alterações irreversíveis na dentição natural do paciente, as quais poderiam, subseqüentemente, comprometer ou exacerbar seus sintomas. E se a terapia com placa for bem sucedida, o paciente poderá 
manter o uso da mesma placa, conforme necessário, salientando-se que elas nunca farão nenhum mal a eles mesmos.

A fim de examinar os efeitos do uso placas intra-orais sobre a morfologia da ATM, SINDELAR; EDWARDS; HERRING ${ }^{167}$, em 2002, usaram 19 pequenos porcos fêmeas que foram divididos em 3 grupos: placa estabilizadora, placa protrusiva e um grupo controle sem placa. As placas foram usadas por 2 meses e depois os discos articulares foram removidos para exame histológico e análise estereológica. Além disso, as superfícies articulares da fossa temporal e do côndilo foram dissecadas e examinadas com auxílio de microscópios na busca de sinais de alterações degenerativas. Os resultados indicaram que embora as placas não tenham nenhum efeito sobre as dimensões do crânio, o mesmo não foi observado nas articulações que sofreram alterações, como os discos do grupo com placas protrusivas que mostraram não só um aumento em espessura da banda posterior, como também pequenas alterações na orientação do colágeno de sua banda anterior. Além disso, os autores verificaram a presença de defeitos ósseos degenerativos no lado medial do côndilo mandibular, em metade dos animais com placa, indicando que o uso prolongado de placas pode induzir à remodelação e até a injúria dos tecidos da articulação temporomandibular. 
Proposição 


\section{3 - PROPOSIÇÃO}

O presente estudo propõe-se a verificar a eficácia de placas com guia balanceada no controle dos desarranjos internos da ATM, quando comparadas a placas com guias de desoclusão pelo canino e placas não oclusivas nos seguintes parâmetros:

1. dor relatada pelo paciente;

2. sensibilidade articular e muscular à palpação;

3. movimentação mandibular;

4. detecção de ruídos articulares;

5. relato pelo paciente do conforto, barulho na ATM e alteração oclusal. 
Material e Métodos 


\section{4 - MATERIAL E MÉTODOS}

\section{1 - MATERIAL}

\subsection{1 -Amostra}

Esta pesquisa foi realizada utilizando-se uma amostra composta por 57 indivíduos com idade entre 14 e 73 anos, selecionados entre os pacientes que procuraram tratamento no Centro de Dor Orofacial e DTM, do Departamento de Prótese da Faculdade de Odontologia de Bauru, da Universidade de São Paulo, no período de agosto a outubro de 2001. Os pacientes foram distribuídos em três grupos, descritos a seguir:

\section{Grupo I - Experimental}

Composto por 19 indivíduos, sendo 18 mulheres e 1 homem, com idade entre 17 e 44 anos, que receberam como forma de tratamento uma placa estabilizadora modificada, cujo desenho permite que durante os movimentos excursivos (para a esquerda, direita ou para anterior) haja sempre contato simultâneo dos dentes (pelo menos um ou dois) em todos os segmentos da placa (anterior, esquerdo e direito), estabelecendo, assim, uma oclusão balanceada, de maneira a não proporcionar a desoclusão dos dentes posteriores. 

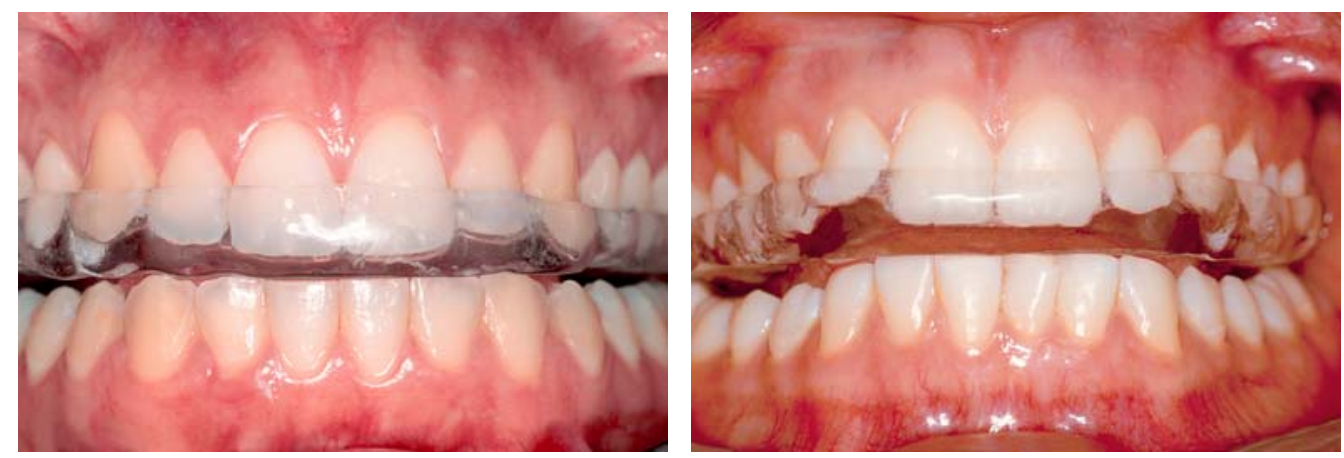

Figura 1- Placa estabilizadora com guia balanceada do Grupo I

\section{Grupo II - Experimental}

Composto por 20 indivíduos, sendo 19 mulheres e 1 homem, com idade entre 18 e 73 anos, que receberam como forma de tratamento uma placa estabilizadora (placa miorrelaxante convencional), cujo desenho proporciona a desoclusão dos dentes posteriores através do contato dos caninos durante os movimentos laterais, e dos dentes anteriores durante movimento protrusivo.
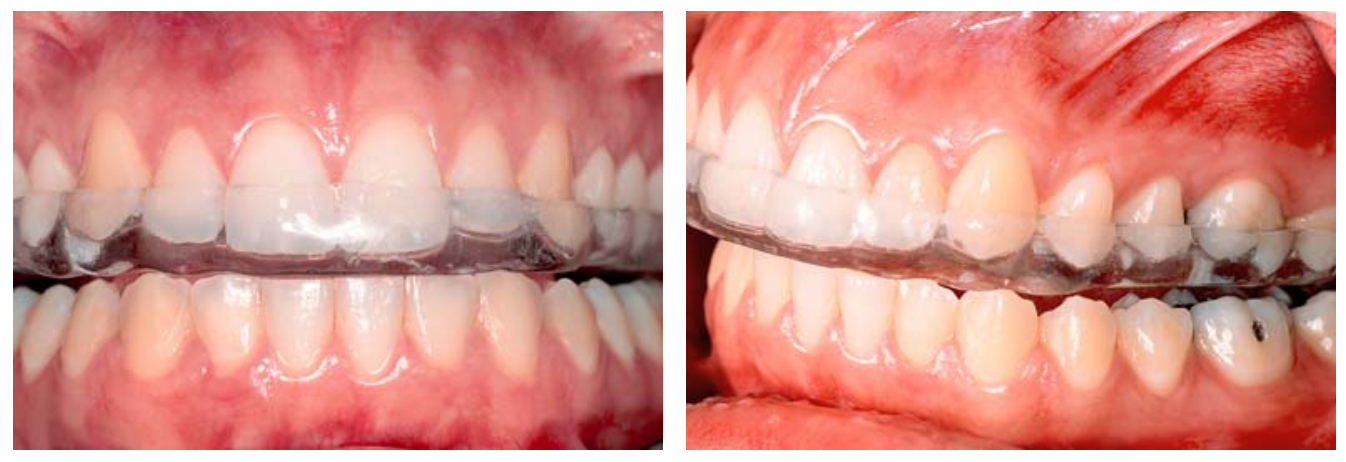

Figura 2 - Placa estabilizadora com guia pelo caninodo Grupo II 


\section{Grupo III - Placebo}

Composto por 18 indivíduos, sendo 15 mulheres e 3 homens, que receberam como forma de tratamento uma placa não oclusiva (PNO), confeccionada na arcada inferior, não interferindo com a oclusão do paciente.
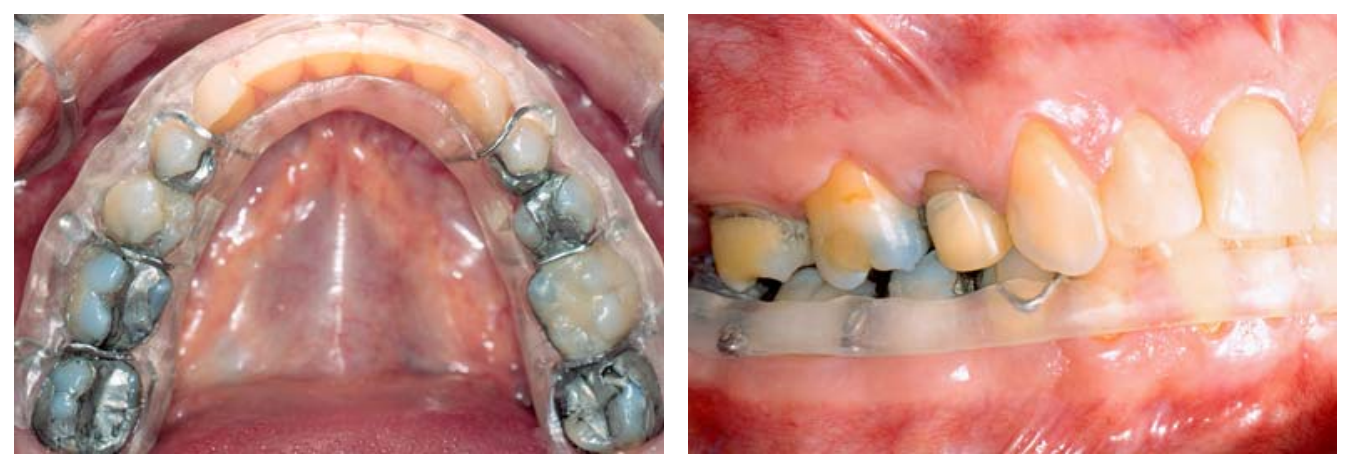

Figura 3 - Placa não oclusiva do grupo III

De acordo com os códigos de ética, todos os pacientes foram informados e esclarecidos sobre o propósito da pesquisa e sobre o método de tratamento a ser utilizado em cada um. Sendo assim, concordaram com a pesquisa, autorizando submeter-se a este estudo e à posterior divulgação dos resultados encontrados.

O modelo de autorização para pesquisa clínica e execução de tratamento está de acordo com as normas do Comitê de Ética da Faculdade de Odontologia de Bauru - USP (anexo I). 


\subsection{2 - Fichas de exames}

Para a coleta de dados relativos aos sinais e sintomas de DTM, foram utilizadas três fichas clínicas específicas, elaboradas a partir de fichas pré-existentes pertencentes ao Departamento de Prótese da Faculdade de Odontologia de Bauru da Universidade de São Paulo. Cada ficha teve uma finalidade específica como descrito a seguir:

Ficha A: Utilizada para o exame clínico inicial (anexo II)

Utilizada no primeiro atendimento, antes da instalação da placa, na identificação dos pacientes, da história clínica (anamnese) e dos dados relativos aos sinais e sintomas de DTM (Exame físico - Anexo II), ou seja, nessa ficha procurou-se:

a) fazer um resumo da história geral das queixas principais dos pacientes;

b) verificar a presença de ruídos articulares;

c) verificar se havia limitação ou dificuldades de movimentação mandibular (desvio ou deflexão);

d) anotar a extensão dos movimentos mandibulares (abertura máxima, lateralidade esquerda e direita e protrusão); 
e) registrar a sensibilidade à dor, pela palpação da ATM e dos músculos elevadores da mandíbula.

Ficha B: Utilizada para reavaliação (anexo III);

Utilizada para reavaliação dos pacientes, composta basicamente pelos mesmos itens verificados na ficha anterior, onde eram registrados os sinais e sintomas do paciente, a qual foi preenchida a cada retorno do mesmo para o acompanhamento da melhora dos sinais e sintomas de DTM. Constava, ainda, desta ficha, um questionário para opinião do paciente referente à alterações na oclusão e ruídos e ao conforto (ou desconforto) pelo uso da placa. Para cada item, o paciente tinha as opções: "manteve-se", "alterou-se para melhor" ou "alterou-se para pior". (Anexo III)

Ficha C: Utilizada para a obtenção da escala de análise visual da dor (EAV) (Anexo IV).

Direcionada ao paciente para mensuração da dor, usada sempre antes do início de cada sessão de reavaliação. Era composta por:

a) identificação do paciente;

b) Escala de Análise Visual de dor (EAV), formada por um traço horizontal de $100 \mathrm{~mm}$, onde em seu extremo 
esquerdo lia-se "sem dor" e no direito, "pior dor sentida", no qual o paciente assinalava com um traço vertical a posição que melhor indicava o grau de dor sentida naquele momento.

Em todas as fichas foram registrados os dados pessoais dos indivíduos relativos ao mesmo: idade, sexo, estado civil, endereço e telefone.

\section{2 - MÉTODO}

\subsubsection{Seleção dos pacientes}

Foram seguidos os critérios de seleção baseados na anamnese detalhada e exame físico padronizado, de acordo com o modelo de ficha de histórico e exame físico preconizado pela clínica de Dor e Disfunção Temporomandibular da Faculdade de Odontologia de Bauru, da Universidade de São Paulo. Essa ficha inclui registro dos dados pessoais dos indivíduos, como nome e idade, bem como, a história médica e exame físico do paciente (anexo II).

Os critérios de inclusão dos pacientes na amostra compreenderam indivíduos com sinais e sintomas de Disfunção Temporomandibular de origem articular; caracterizado por presença de estalido articular, ou seja, estalido na abertura e no fechamento; queixa de 
dor na ATM e sensibilidade à palpação na ATM em, pelo menos, um dos lados da face e por um período mínimo de 6 meses.

Foram excluídos aqueles pacientes com as seguintes características:

a) história de artrite sistêmica, traumas recentes e história de cirurgia prévia da ATM;

b) pacientes com doença articular degenerativa, diagnosticados por crepitação na ATM;

c) pacientes com doença sistêmica ou outra patologia que pudesse confundir o diagnóstico;

d) pacientes que exibiam um estalido assintomático sem outras característica de desordem temporomandibular de origem articular;

e) portador de prótese total, removível;

f) ausência dos dentes posteriores.

Dessa forma, o processo de inclusão nos grupos I, II ou III foi realizado de maneira aleatória, porém, tomando-se o cuidado de, anteriormente à inclusão em cada grupo, separar proporcionalmente os pacientes em relação à dor (estratificação). Primeiramente os pacientes foram separados em relação à sensibilidade à dor em: dor severa, dor 
moderada e dor leve, de acordo com a avaliação da Escala de Análise Visual (EAV) e palpação da ATM e músculos da mastigação.

Foi considerada dor grave, aqueles pacientes com EAV com valor maior que 8 e palpação da articulação e músculos da mastigação com valor igual a 3; com dor moderada, aqueles pacientes com EAV maior ou igual a 7 e menor ou igual a 8 e palpação da ATM e músculos da mastigação igual a 2; e com dor leve, aqueles pacientes com EAV menor do que 7 e palpação da ATM e músculos da mastigação igual a 1.

\subsection{2 -Procedimento para confecção da placa}

\subsubsection{1 - Obtenção dos modelos de gesso}

Os pacientes foram submetidos à moldagem através do uso de moldeiras de estoque do tipo Vernes, adaptadas com cera utilidade (Horus-Herpe Produtos Dentários), se necessário, e alginato (Jeltrate, Caulk, Dentsply, tipo II, presa normal). Os moldes obtidos foram vazados em gesso pedra (Herodent, Soli-Rock, Vigodent) na proporção indicada pelo fabricante.

\subsubsection{2 - Montagem em articulador semi-ajustável (ASA)}

O uso do arco facial para montagem do modelo superior tem por finalidade relacionar a maxila ao eixo terminal de rotação condilar, para possibilitar um arco de fechamento correto do articulador e conseqüentemente, contatos oclusais mais precisos. 
O registro da relação maxilo-mandibular foi realizado com fitas calibradoras de acetato, como sugerido por $\operatorname{LONG}^{100}$, em 1973, na dimensão vertical em que a placa seria confeccionada, ou seja, aproximadamente a $2 \mathrm{~mm}$ do primeiro contato oclusal, associado à manipulação na ponta do mento (guia não forçada). Após definido o espaço de $2 \mathrm{~mm}$ entre os dentes posteriores, com o número de tiras selecionadas entre os incisivos centrais superiores e inferiores e colocado silicone de condensação sobre a oclusal dos dentes (para registro das duas arcadas); manipulou-se a mandíbula pela técnica da ponta do mento suavemente, de maneira a não forçar os côndilos contra a ATM, para que os pacientes não sentissem dor, guiando-a até tocar as tiras.

O modelo superior foi montado através do arco facial e o inferior articulado ao superior pelo registro da relação maxilo-mandibular, executado com silicone de condensação. O modelo superior, no qual foi confeccionado a placa, foi montado pela técnica "split-cast", de maneira que, após o enceramento e a prensagem com resina, este pudesse retornar ao articulador para ajuste oclusal da mesma e reduzisse, assim, o tempo de ajuste clínico.

Para a confecção da placa não oclusal, os modelos foram articulados por oposição direta e não foi preciso o uso de articuladores em sua montagem, pois a oclusão não foi envolvida em sua confecção. 


\subsubsection{3 - Enceramento das placas}

Após o alívio das áreas retentivas por palatino e oclusal em gesso comum, procedia-se ao enceramento das placas do Grupo II, utilizando-se cera $n^{\circ} 7$ (Duradent-Odonto Comercial Importadora LTDA), de maneira a atingir $2 \mathrm{~mm}$ da face vestibular de todos os dentes, toda a face oclusal, incisal e palatina, obtendo contatos simultâneos e uniformes na posição de intercuspidação, além de desoclusão dos dentes posteriores pelos anteriores (guia anterior), e da desoclusão de todos os dentes pelo canino durante os movimentos excursivos.

Para o enceramento das placas do Grupo I, utilizou-se da mesma técnica anteriormente descrita, apenas com a modificação do desenho da guia, na qual estabeleceu-se contato simultâneo dos dentes nos movimentos excursivos, conforme já relatado.

Para a confecção das placas não oclusivas, os modelos foram articulados em oposição direta e a oclusão verificada de modo a possibilitar a confecção da placa sem interferência e sem montagem em articulador, de maneira que, na máxima intercuspidação, assim como nos movimentos excursivos de lateralidade e protrusão, apenas os dentes do paciente entrassem em contato, sem interferência da resina. 


\subsubsection{4 - Prensagem, acabamento e polimento das placas}

As placas dos três grupos receberam a mesma técnica de prensagem, acabamento e polimento, ou seja, as placas enceradas foram prensadas em panela de pressão de 6 litros a 15 libras, com resina acrílica termopolimerizável (Clássico, Artigos Odontológico), recebendo posteriormente ao ajuste oclusal, no articulador, acabamento com pedras montadas (Mini e Maxi-cut) e polimento com pedra-pomes e branco de Espanha.

\subsubsection{5 - Instalação das placas}

Durante a instalação da placa estabilizadora convencional (Grupo I), procurou-se propiciar: 1) retenção adequada; 2) eliminação de pressão indevida ou incômoda nos dentes; 3) contatos simultâneos e uniformes de todas as cúspides vestibulares dos dentes inferiores pelo uso de fitas detectoras de contatos (Accu-film II, red-black, USA); 4) máximo conforto; 5) desoclusão pelos caninos e guia anterior adequada, promovendo desoclusão nos dentes posteriores. 

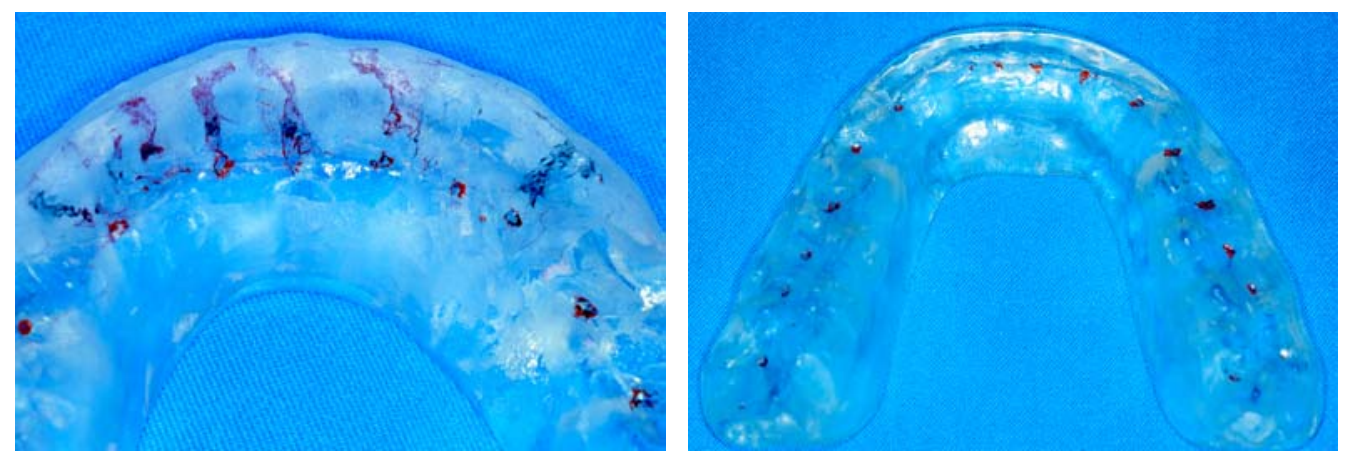

Figura 4- $\quad$ Ajuste oclusal

Para a instalação da placa estabilizadora de oclusão balanceada bilateral (Grupo II), buscava-se propiciar, além dos quatros primeiros itens citados anteriormente para o Grupo I, contato simultâneo dos dentes posteriores nos três lados da placa, durante os movimentos excursivos (oclusão balanceada bilateral), não proporcionando, assim, a desoclusão dos dentes posteriores (oclusão balanceada).

Para o ajuste das placas não oclusivas (Grupo III) na boca, apesar do alívio realizado nos modelos, freqüentemente era necessário desgastar a resina, principalmente internamente por vestibular, para que a placa pudesse ser inserida e removida sem interferência com os tecidos periodontais. A verificação da oclusão era feita tanto no fechamento em máxima intercuspidação habitual (MIH) como nos movimentos excursivos de lateralidade e protrusão, de tal forma que apenas os dentes do paciente entrassem em contato, sem interferência da resina. 


\subsubsection{6 - Instruções para o paciente}

Após o ajuste e polimento (caso fosse necessário), todos os indivíduos dos três grupos foram orientados a usar a placa somente durante a noite, para dormir, e a retornar para controle de acordo com as datas previamente assinaladas para reavaliação.

Foi informado a todos os pacientes que, após 6 meses (período do experimento), a placa que obtivesse os piores resultados na redução dos sinais e sintomas de DTM seria substituída pela placa que obtivesse os melhores resultados. Foi dito, também, que todas as placas eram efetivas no tratamento das queixas sentidas pelo paciente, sendo que algumas possuíam um efeito mais rápido na diminuição das dores que outras, e que nós não sabíamos precisar, entre uma e outra, qual a melhor.

Para não haver interferência nos resultados obtidos com o uso das placas, os pacientes foram orientados a não fazer o uso de outras formas de tratamento para controle da dor, como tratamento fisioterápico profissional e uso de analgésicos e relaxantes musculares.

\subsection{3 - Avaliação do paciente}

Em todas as avaliações, antes do exame físico, todos os pacientes foram solicitados a graduar sua dor de acordo com a Escala de Análise Visual (EAV) graduada em milímetros (0 a 100mm). O resultado, assim obtido, era transferido em números, obtidos pela medida do início da 
linha até o traço assinalado. Tal mensuração foi o parâmetro de acompanhamento subjetivo de evolução dos sintomas nos diferente grupos.

A ficha $B$, utilizada na reavaliação da amostra (anexo III), foi utilizada em todas as consultas de acompanhamento para acompanhar os sinais e sintomas de maneira objetiva durante o desenvolvimento deste trabalho, sendo preenchida a cada retorno durante o controle da amostra. Por meio dela foram realizadas a análise dos movimentos da mandíbula, dos ruídos articulares, palpação da ATM e dos músculos mastigatórios (temporal e masseter) conforme instruções a seguir:

\subsubsection{1 - Análise dos movimentos da mandíbula}

\section{Abertura Bucal:}

Para se obter o valor da abertura bucal máxima, solicitavase inicialmente ao paciente que ocluísse normalmente. Dessa forma, faziase a demarcação do trespasse vertical. A demarcação coincide com as bordas incisais dos dentes superiores sobre os inferiores. Através de um paquímetro, tomava-se como referência a linha mediana e a abertura bucal ativa era realizada, solicitando-se ao paciente que abrisse a boca ao máximo. O valor da abertura bucal máxima representava a distância entre as bordas incisais superiores e inferiores, acrescido do trespasse vertical. 


\section{Movimentos laterais:}

A análise dos movimentos laterais era realizada, solicitandose ao paciente que movimentasse a mandíbula para um dos lados. A mensuração era feita utilizando-se uma régua posicionada no plano horizontal, tomando como base inicial uma linha vertical que passava próxima da linha média do incisivo central superior e que se estendia para a vestibular do inferior, fazendo-se a medida da linha superior até a linha inferior das excursões laterais máximas.

O movimento de protrusão era medido usando-se uma régua posicionada no plano horizontal, tocando a face vestibular do incisivo central superior. Com o paciente em posição protrusiva, tomou-se a medida até a face vestibular do incisivo central inferior, acrescentando-se, agora, o trespasse horizontal, que é a medida entre a face palatina dos incisivos superiores até a face vestibular dos incisivos inferiores.

\subsubsection{2 - Análise de ruídos articulares}

A análise dos ruídos articulares foi realizada por inspeção manual, posicionando-se levemente os dedos indicadores na região correspondente ao pólo lateral do côndilo, à frente do meato acústico externo, enquanto o paciente realizava movimentos de abertura e fechamento da boca. O sistema adotado na avaliação desses ruídos foi simplesmente verificar se ocorria ruído no lado esquerdo e/ou direito ou em 
nenhum dos lados, com o decorrer do tratamento, já que inicialmente todos os indivíduos apresentavam ruídos articulares.

\subsubsection{3 - Palpação da ATM}

Previamente ao exame de palpação, toda a amostra foi orientada quanto à diferença entre sensação de pressão e dor para uma melhor análise da resposta ao procedimento de palpação. Para a avaliação da ATM, foi utilizada a palpação digital bilateral com os dedos indicadores posicionados, aproximadamente, de 10 a $20 \mathrm{~mm}$ à frente do conduto auditivo externo. Pressionou-se a região delicadamente e de maneira contínua, por 2 segundos, com uma carga de, aproximadamente, 1000 gramas, de acordo com PERTES; GROSS ${ }^{139}, 1995$.

Dessa forma, avaliou-se a ATM com boca fechada (aspecto lateral) e boca aberta (aspecto posterior).

A graduação da resposta do paciente à palpação da ATM foi feita nos seguintes valores, de acordo com PERTES; GROSS ${ }^{139}$ :

Valor 0 - ausência de sensibilidade à palpação;

Valor 1 - sensibilidade leve;

Valor 2 - sensibilidade moderada;

Valor 3 - sensibilidade severa. 


\subsubsection{4 - Palpação muscular}

Foi realizada bilateralmente, exercendo pressão firme, porém de maneira suave e constante, de aproximadamente 1500 gramas, de acordo com CONTI et al. ${ }^{39}, 1996$.

Assim, baseados nas reações demonstradas pelos indivíduos, o grau de dor foi, também, classificado de acordo com os critérios de PERTES; GROSS ${ }^{139}$ :

Valor 0 - sem dor;

Valor 1 - dor leve;

Valor 2 - dor moderada;

Valor 3 - dor severa.

Os músculos avaliados durante a palpação foram o músculo masseter superficial (origem, corpo e inserção do músculo), músculo masseter profundo e o músculo temporal (porções anterior, média e posterior). 


\subsection{4 - Reavaliações}

Após a instalação das placas, os indivíduos foram orientados quanto a seus futuros retornos:

Retorno 1- uma semana após a instalação da placa;

Retorno 2- após 15 dias da instalação da placa;

Retorno 3- após 1 mês da instalação da placa;

Retorno 4- após 3 meses de instalação da placa;

Retorno 5- após 6 meses de instalação da placa.

Durante todos os retornos dos indivíduos realizou-se o mesmo procedimento executado no ato da instalação da placa.

\subsection{5 - Análise estatística}

Análise de variância (ANOVA) para mensurações repetidas foi utilizado para realizar as comparações entre os grupos, nos diferentes tempos de avaliação, para as diferentes variáveis de distribuição normal. Testes post-hhoc (Lubkey) foram aplicados, quando necessário, para detecção das diferenças. 
Testes de Kruskal-Wallis foram utilizados para análise das variáveis de distribuição não normal. Quando necessário, o teste de Dunn detectou as diferenças entre os grupos.

Teste de Friedman foi utilizado para avaliar o comportamento individual de cada grupo durante o período da pesquisa.

Testes de qui-quadrado foram utilizados para as variáveis relativas com relato do paciente (ruídos, conforto e alterações na oclusão) 


\section{CARTA DE INFORMAÇÃO AO PACIENTE}

A Faculdade de Odontologia de Bauru, através do doutorando Carlos Neanes Santos e sob a orientação do Prof. Dr. Paulo César Rodrigues Conti, realiza a pesquisa "Avaliação longitudinal de diferentes desenhos oclusais em placas oclusais no controle de patologias da ATM", com o intuito de melhorar, cada vez mais, uma das formas de tratamento mais utilizadas em pacientes com dor na articulação da boca.

Esta pesquisa será realizada com 60 pacientes divididos igualmente em 3 grupos com três tipos de placas diferentes sendo duas experimentais e os pacientes deverão usar as placas somente ao dormir.

A avaliação deverá ser feita através da escala de análise visual de dor e da palpação da ATM dos músculos da mastigação, da abertura da boca, dos movimentos para frente e análise dos ruídos articulares por um período de 6 meses.

Esse tipo de tratamento, já comprovado como eficaz, reduz a dor e melhora a qualidade de vida do paciente. Mesmo a placa usada no grupo controle tem se mostrado eficaz neste tipo de tratamento.

A sua colaboração é importante para a nossa pesquisa. Para tanto, após a instalação da placa, você deverá retornar a nossa clínica 5 vezes para avaliação de seus sintomas e sinais clínicos. Além disso, em virtude de não conseguirmos apoio financeiro, haverá um custo de sessenta reais, que poderão ser pagos em 2 vezes para a confecção das placas, já que a mesma não confeccionada em nossa faculdade.

Durante o tratamento, o paciente tem a total liberdade para opinar, perguntar a respeito dos benefícios, riscos e procedimentos e até mesmo para desistir de participar dessa pesquisa, sem qualquer prejuízo à continuidade do tratamento nessa Instituição.

A identidade de cada indivíduo será mantida em absoluto sigilo durante e após a realização dessa pesquisa.

Os pacientes que apresentarem persistência dos sinais e sintomas serão atendidos na Clínica de Disfunção Temporomandibular da FOB-USP.

\section{TERMO DE CONSENTIMENTO LIVRE E ESCLARECIDO}

Pelo presente instrumento que atende às exigências legais, o

$\operatorname{Sr}(a)$ portador da cédula de identidade , após leitura minuciosa

da CARTA DE INFORMAÇÃO AO PACIENTE, devidamente explicada 
pelos profissionais em seus mínimos detalhes, ciente dos serviços e procedimentos aos quais será submetido, não restando quaisquer dúvidas a respeito do lido e explicado, firma seu CONSENTIMENTO LIVRE E ESCLARECIDO concordando em participar da pesquisa proposta.

Fica claro que o paciente ou seu represnetante legal pode a qualquer momento retirar seu CONSENTIMENTO LIVRE E ESCLARECIDO e deixar de participar desta pesquisa e ciente de que todas as informações prestadas tornaram-se confidenciais e guardadas por força de sigilo profissional (Art. $9^{\circ}$ do Código de Ética Odontológica).

Por estar de acordo assina o presente termo.

Bauru-SP, de de 2002. 


\section{Ficha de histórico e exame clínico}

Faculdade de Odontologia de Bauru - USP

Departamento de Prótese

Clínica de Disfunção Temporomandibular e Dores Orofaciais

Tese - Doutorado: CD Carlos Neanes Santos

Orientador: Prof. Dr. Paulo César Rodrigues Conti

\section{História e Exame}

Nome:

Idade:

Data:

Tel:

Acidentes relacionados: $\square$ Sim $\quad \square$ Não

Queixa(s) principal(is): (em ordem de severidade)

1

2

Queixa principal 1:

Início:

Localização:

Freqüência:

Intensidade:

Qualidade:

Queixa principal 2:

Início:

Localização:

Freqüência:

Intensidade:

Qualidade:

Medicação atual e doses:

Medicação passada e doses:

Teste ou radiografias realizadas:

História parafuncionais e ocupacionais:

Ranger os dentes

NEG

POS

Apertamento

Roer unhas

Mascar chicletes

Uso contínuo do telefone

Uso contínuo do computador

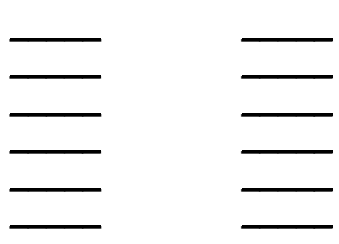




\section{Exame Clínico}

\section{A- Movimentação}

Dor

$\begin{array}{lll}\text { Abertura máxima } & \mathrm{mm} \\ \text { Protrusivo } & \mathrm{mm} & \\ \text { Lateralidade direita } & \mathrm{mm} & \\ \text { Lateralidade esquerda } & \mathrm{mm} & \\ & & \\ \text { Abertura: } \quad \square \text { Simétrica } \quad \square \text { Desvio } \quad \square \text { Deflexão }\end{array}$

B- Ruídos articulares:
$\square \operatorname{sim}$
$\square$ Não

\section{C- Palpação da ATM:}

$0=$ Sem dor $1=$ Dor leve $\quad 2=$ Dor moderada $3=$ Dor severa

$\begin{array}{lll}\text { Aspecto lateral } & \mathrm{D} \\ \text { Aspecto posterior } & -\end{array}$

2 - EXAME MUSCULAR - SENSIBILIDADE À PALPAÇÃO:

$0=$ Sem dor $\quad 1=$ Dor leve $2=$ Dor moderada $3=$ Dor severa

D E

Temporal:

Anterior

Médio

Posterior

Masseter superficial:

Origem

Corpo

Inserção

4 Impressões diagnósticas:

Capsulite/Sinovite

Deslocamento de disco com redução Deslocamento de disco sem redução Hipermobilidade

$\begin{array}{ll}D & E \\ D & E \\ D & E \\ D & E\end{array}$ 


\section{Ficha de Reavaliação}

Faculdade de Odontologia de Bauru - USP

Departamento de Prótese

Clínica de Disfunção Temporomandibular e Dores Orofaciais

Tese - Doutorado: CD Carlos Neanes Santos

Orientador: Prof. Dr. Paulo César Rodrigues Conti

Nome:

Data:

Grupo:

$n^{\circ}$

Controle $\mathrm{n}^{\circ}$

A- Movimentação:

\begin{tabular}{|c|c|c|c|c|c|}
\hline \multirow{4}{*}{\multicolumn{2}{|c|}{$\begin{array}{l}\text { Abertura máxima } \\
\text { Protrusivo } \\
\text { Lateralidade direita } \\
\text { Lateralidade esquerda }\end{array}$}} & \multicolumn{4}{|c|}{ Dor } \\
\hline & & & $-\mathrm{mm}$ & & \\
\hline & & & $\mathrm{mm}$ & 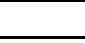 & \\
\hline & & & _mm & & \\
\hline Abertura: & $\square$ Simétrica & & Desvio & \multicolumn{2}{|c|}{$\square$ Deflexão } \\
\hline \multicolumn{6}{|c|}{ B- Ruídos articulares: } \\
\hline \multicolumn{2}{|c|}{$\square \operatorname{Sim}$} & \multicolumn{4}{|c|}{$\square$ Não } \\
\hline \multicolumn{6}{|c|}{ C - Palpação da ATM: } \\
\hline \multirow{2}{*}{ = Sem dor } & 1 = Dor leve & \multicolumn{3}{|c|}{2 = Dor moderada } & 3 = Dor severa \\
\hline & & $\mathrm{D}$ & & $E$ & \\
\hline Aspecto poste & & & & & \\
\hline
\end{tabular}

2 EXAME MUSCULAR - SENSIBILIDADE À PALPAÇÃO:

$0=$ Sem dor $1=$ Dor leve $2=$ Dor moderada $3=$ Dor severa

D E

Temporal:

Anterior

Médio

Posterior

Masseter superficial:

Origem

Corpo

Inserção 
Avaliação final do paciente:

A- Em relação à mudança da mordida: Manteve-se Alterou-se para melhor Alterou-se para pior

B- Em relação ao estalido: Manteve-se Alterou-se para melhor Alterou-se para pior Não sabe

C- Em relação ao conforto com a placa: Manteve-se Alterou-se para melhor Alterou-se para pior 
ANEXO IV

\section{Ficha de Reavaliação}

Faculdade de Odontologia de Bauru - USP

Departamento de Prótese

Clínica de Disfunção Temporomandibular e Dores Orofaciais

Tese - Doutorado: CD Carlos Neanes Santos

Orientador: Prof. Dr. Paulo César Rodrigues Conti

Nome:

Data:

1

Avaliação:

\section{Escala de Análise Visual}

Indique a média de seu nível de dor nesse momento, marcando com uma linha vertical a escala abaixo. A extremidade esquerda indica ausência total de dor e a extremidade direita indica a pior dor imaginável.

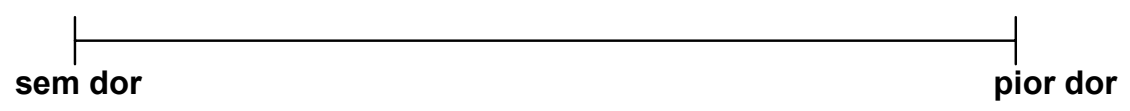


Resultados 


\section{5 - RESULTADOS}

\section{1 - DADOS GERAIS}

A amostra do presente trabalho constou de 57 indivíduos com média de idade de 29,95, sendo 5 homens e 52 mulheres (Tabela 1).

Tabela 1 - Média de distribuição da idade entre os grupos e o respectivo desvio padrão.

\begin{tabular}{lcc}
\hline \multicolumn{1}{c}{ GRUPO } & Idade média & $\mathbf{n}$ \\
\hline I- Placa balanceada & $28,95 \pm 8,63$ & $19(33,3 \%)$ \\
\hline II- Placa com guia & $31,35 \pm 13,25$ & $20(35,1 \%)$ \\
\hline III- Placebo & $29,56 \pm 10,65$ & $18(31,6 \%)$ \\
\hline Total & 29,95 & $57(100 \%)$ \\
\hline
\end{tabular}

Com relação à distribuição de gênero, observou-se que o grupo I (placa balanceada) era composto por 1 homem e 18 mulheres, o grupo II (placa com guia) era composto por 1 homem e 19 mulheres e no grupo placebo havia 3 homens e 15 mulheres (Tabela 2).

Tabela 2- Distribuição da amostra entre os grupos de acordo com o gênero

\begin{tabular}{lccc}
\hline \multicolumn{1}{c}{ GRUPO } & Feminino & Masculino & $\mathbf{n}$ \\
\hline I- Placa balanceada & 18 & 1 & 19 \\
& $94,74 \%$ & $5,26 \%$ & $100 \%$ \\
\hline II- Placa com guia & 19 & 1 & 20 \\
& $95,0 \%$ & $5,0 \%$ & $100 \%$ \\
\hline III- Placebo & 15 & 3 & 18 \\
& $83,3 \%$ & $16,7 \%$ & $100 \%$ \\
\hline Total & 52 & 5 & 57 \\
& $91,2 \%$ & $8,8 \%$ & $100 \%$ \\
\hline
\end{tabular}




\section{2 - ESCALA DE ANÁLISE VISUAL DE DOR}

A análise do relato de dor pela amostra foi realizada por meio das variações decorrentes do tempo (intra-grupo) e entre os grupos nos diversos períodos de mensuração (inter-grupos).

A análise dos resultados obtidos para esta variável, mensurada por meio da EAV para a amostra total, apresentou o valor inicial de $64,63 \mathrm{~mm}$ e um valor final de $15,7 \mathrm{~mm}$.

Os resultados mostraram que, independente do grupo, os valores médios da EAV diminuíram. No grupo I (com placa balanceada), a EAV inicial média foi de $63,2 \mathrm{~mm}$ e a final de $10,5 \mathrm{~mm}$. No grupo II (que usou placa com guia), o valor inicial médio de EAV foi de $68,0 \mathrm{~mm}$ e o valor final de $9,5 \mathrm{~mm}$ e no grupo placebo, a EAV inicial média foi de $62,7 \mathrm{~mm}$ e a final foi de 27,2mm (Tabela ).

Tabela 3- Distribuição das médias dos valores de EAV nos diferentes períodos de mensuração dos grupos (em $\mathrm{mm}$ ).

\begin{tabular}{lccccccc}
\hline \multicolumn{1}{c}{ GRUPO } & Inicial & 7 dias & 15 dias & 1 mês & 3 meses & $\mathbf{6 ~ m e s e s}$ & $\begin{array}{c}\text { Variaçã } \\
\text { o total }\end{array}$ \\
\hline I- Placa balanceada & 63,2 & 43,2 & 36,8 & 16,3 & 15,3 & 10,5 & $-52,7$ \\
\hline II- Placa com guia & 68,0 & 45,0 & 32,0 & 25,0 & 18,0 & 9,5 & $-58,5$ \\
\hline III- Placebo & 62,7 & 56,6 & 50,0 & 40,6 & 35,0 & 27,2 & $-35,5$ \\
\hline Total & 64,6 & 48,2 & 39,6 & 81,9 & 33,8 & 15,7 & $-48,9$ \\
\hline
\end{tabular}


O teste ANOVA para mensurações repetidas mostrou que houve melhora no relato de dor dos três grupos analisados $(p<0,001)$. Em seguida, realizou-se o teste de Tukey para comparações individuais entre os diferentes períodos de mensuração, para os 3 grupos. Os resultados estão representados na Figura 5 e nas Tabela 4, 5 e 6.

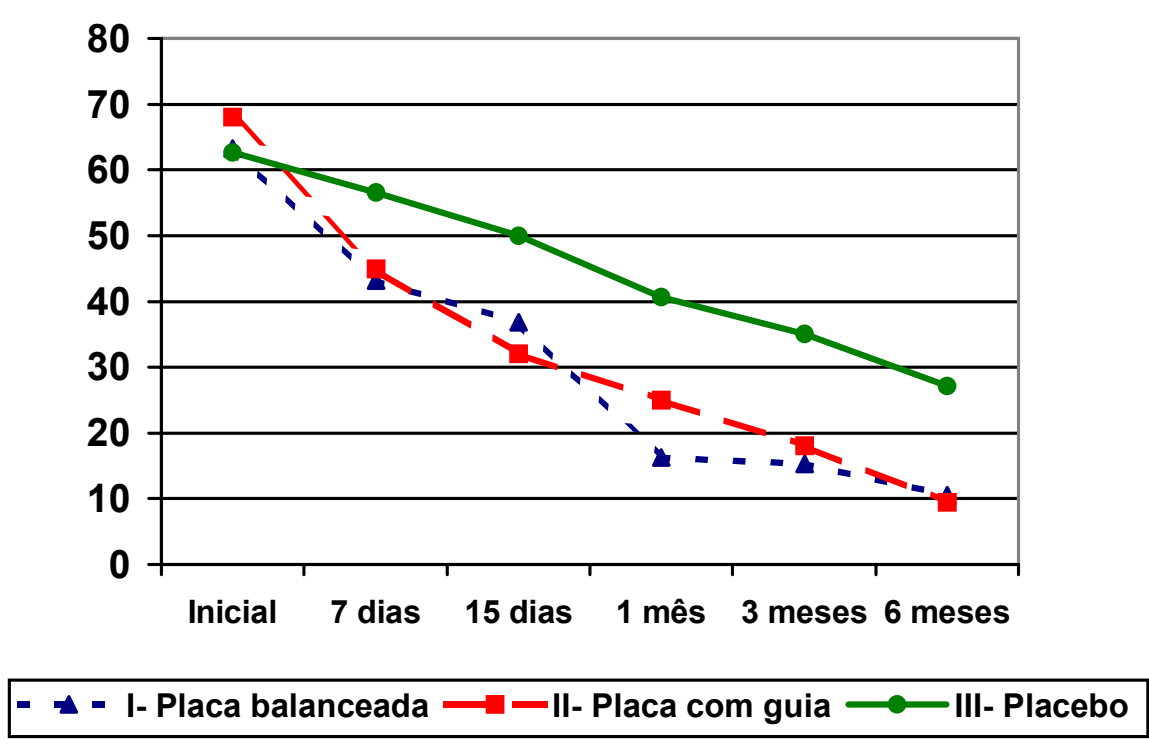

Figura 5- Variação dos valores da EAV $(\mathrm{mm})$ nos diferentes grupos ao longo do tempo.

Tabela 4- Comparações individuais (ANOVA - Tukey) dos resultados obtidos dos valores de EAV,para o grupo I (placa balanceada)

\begin{tabular}{|c|c|c|c|c|}
\hline Tempo & Média (mm) & & & \\
\hline Inicial & 63,2 & $x x x x$ & & \\
\hline 7 dias & 43,2 & & $\mathrm{XXXX}$ & \\
\hline 15 dias & 36,8 & & $X X X X$ & \\
\hline 1 mês & 16,3 & & & $x x x x$ \\
\hline 3 meses & 15,3 & & & $x x x x$ \\
\hline 6 meses & 10,5 & & & $x x x x$ \\
\hline
\end{tabular}

xxxx = representação da diferença entre os valores, onde a sua permanência na coluna representa alteração não significativa com relação ao período imediatamente anterior, e a sua mudança de coluna representa alteração significativa com relação ao período representado na coluna anterior. 
Tabela 5- Comparações individuais (ANOVA - Tukey) dos resultados obtidos dos valores de EAV,para o grupo II (placa com guia)

\begin{tabular}{|c|c|c|c|c|c|c|}
\hline Tempo & Média (mm) & & & & & \\
\hline Inicial & 68,0 & $x x x x$ & & & & \\
\hline 7 dias & 45,0 & & XXXX & & & \\
\hline 15 dias & 32,5 & & & $x x x x$ & & \\
\hline 1 mês & 25,5 & & & $x X X X$ & $x X X X$ & \\
\hline 3 meses & 18,0 & & & & $x x x x$ & $x x x x$ \\
\hline 6 meses & 0,95 & & & & & $x x x x$ \\
\hline
\end{tabular}

$x x x x=$ representação da diferença entre os valores, onde a sua permanência na coluna representa alteração não significativa com relação ao período imediatamente anterior, e a sua mudança de coluna representa alteração significativa com relação ao período representado na coluna anterior.

Tabela 6- Comparações individuais (ANOVA - Tukey) dos resultados obtidos dos valores de EAV,para o grupo III (placebo)

\begin{tabular}{|c|c|c|c|c|c|c|}
\hline Tempo & Média $(\mathrm{mm})$ & & & & & \\
\hline Inicial & 62,8 & $x x x x$ & & & & \\
\hline 7 dias & 56,7 & $x x x x$ & $x X X X$ & & & \\
\hline 15 dias & 50,0 & & $x x x x$ & $x x x x$ & & \\
\hline 1 mês & 40,6 & & & $x x x x$ & $x X X X$ & \\
\hline 3 meses & 35,0 & & & & $x x x x$ & $x x x x$ \\
\hline 6 meses & 27,2 & & & & & $x x x x$ \\
\hline
\end{tabular}

$x x x x=$ representação da diferença entre os valores, onde a sua permanência na coluna representa alteração não significativa com relação ao período imediatamente anterior, e a sua mudança de coluna representa alteração significativa com relação ao período representado na coluna anterior.

Para a análise inter-grupos, o teste ANOVA seguido do teste de Tukey indicaram que houve diferença significativa na alteração total da EAV, apenas entre os grupos II (placa com guia) e III (placebo). Não havendo diferença significativa entre os grupos I (placa balanceada) e II (placa com guia); nem entre os grupos I (placa balanceada) e III (placebo) (Tabela 7) 
Tabela 7- Avaliação inter-grupos da alteração total na EAV, após todos os períodos de mensuração, nos 3 grupos (MANOVA Tukey)

\begin{tabular}{l|c|l|l}
\hline \multicolumn{1}{c|}{ Grupo } & $\begin{array}{c}\text { Média da alteração } \\
(\mathbf{m m})\end{array}$ & & \\
\hline II (placa com guia) & $-58,5$ & xxxx & \\
\hline I (placa balanceada) & $-52,6$ & xxxx & XXXX \\
\hline III (placebo) & $-35,6$ & & Xxxx \\
\hline
\end{tabular}

Teste MANOVA entre os grupos- $p=0,012$

$x x x x=$ representação da diferença entre os valores, onde a sua permanência na coluna representa alteração não significativa com relação ao período imediatamente anterior, e a sua mudança de representa alteração significativa com relação ao período representado na coluna anterior.

\section{3 - ABERTURA MÁXIMA}

Com relação ao grau de abertura bucal, a média de abertura bucal inicial e final para toda a amostra foi de $47,06 \mathrm{~mm}$ e $47,99 \mathrm{~mm}$ respectivamente.

Os resultados da evolução dos graus de abertura bucal nos diversos períodos de mensuração em cada grupo encontram-se na Tabela 8.

Tabela 8- Distribuição da média de abertura (em $\mathrm{mm}$ ) entre os grupos nos diferentes períodos de mensuração

\begin{tabular}{lccccccc}
\hline \multicolumn{1}{c}{ GRUPO } & Inicial & 7 dias & 15 dias & 1 mês & 3 meses & $\mathbf{6}$ meses & $\begin{array}{c}\text { Variação } \\
\text { total }\end{array}$ \\
\hline I- Placa balanceada & 46,00 & 46,10 & 47,00 & 46,90 & 47,20 & 47,30 & 1,26 \\
\hline II- Placa com guia & 45,90 & 46,40 & 46,95 & 46,85 & 47,40 & 47,25 & 1,35 \\
\hline III- Placebo & 49,28 & 50,83 & 52,39 & 50,39 & 49,83 & 49,44 & 0,50 \\
\hline Total & 47,06 & 47,77 & 48,78 & 48,04 & 48,14 & 47,99 & 1,03 \\
\hline
\end{tabular}


O teste ANOVA não indicou diferença significativa no grau de abertura bucal máxima entre os diferentes grupos $(p=0,738)$ (Figura 6)

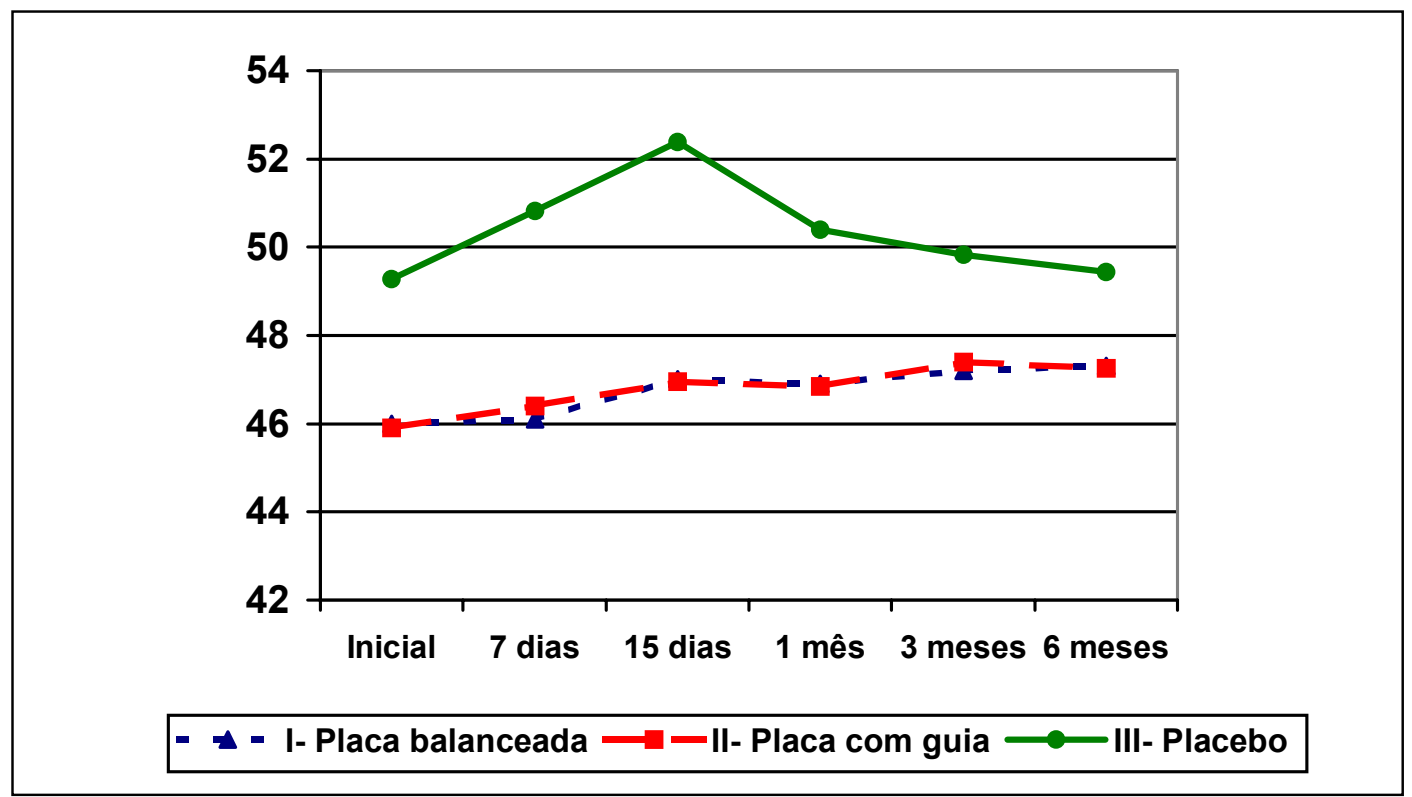

Figura 6- Variação da abertura bucal (em $\mathrm{mm}$ ) nos diferentes grupos, ao longo do tempo

\section{4 - MOVIMENTOS EXCURSIVOS DA MANDÍBULA}

Os movimentos excursivos da mandíbula (lateralidades direita e esquerda e protrusão) foram analisados nos diferentes grupos.

\subsection{1 - Lateralidade Direita}

Os valores das mensurações em milímetros encontram-se descritos na Tabela, para a lateralidade direita, na Tabela 11, para a lateralidade esquerda e na Tabela 12, para protrusão. 
Tabela 9- Distribuição média dos valores de lateralidade direita (em milímetros) entre os grupos nos diferentes períodos de mensuração.

\begin{tabular}{lccccccc}
\hline \multicolumn{1}{c}{ GRUPO } & Inicial & $\mathbf{7}$ dias & $\mathbf{1 5}$ dias & $\mathbf{1}$ mês & $\mathbf{3}$ meses & $\mathbf{6}$ meses & $\begin{array}{c}\text { Variaçã } \\
\text { o total }\end{array}$ \\
\hline I- Placa balanceada & 10,0 & 9,36 & 9,15 & 9,05 & 9,32 & 9,32 & $-0,47$ \\
\hline II- Placa com guia & 9,55 & 9,45 & 9,35 & 9,50 & 9,75 & 10,20 & 0,65 \\
\hline III- Placebo & 9,06 & 8,67 & 9,72 & 10,11 & 9,89 & 10,06 & 1,00 \\
\hline Total & 9,54 & 9,16 & 9,41 & 29,55 & 9,65 & 9,86 & 0,39 \\
\hline
\end{tabular}

Analisou-se a variação inter-grupos da extensão dos movimentos mandibulares excursivos por meio do teste ANOVA.

Verificou-se que, para a lateralidade direita, houve diferença estatisticamente significativa entre os grupos $(p=0,047)$. E, o teste de Tukey indicou que essa diferença encontrava-se entre os grupos I (placa balanceada) e III (placebo), para o qual ocorreu maior variação, conforme exposto na Tabela 10. Não havendo diferenças na variação do movimento de lateralidade direita entre os grupos I (placa balanceada) e II (placa com guia), nem entre os grupos II (placa com guia) e III (placebo).

Tabela 10- Avaliação inter-grupos da variação total na lateralidade direita, após todos os períodos de mensuração, nos 3 grupos (ANOVA - Tukey)

\begin{tabular}{l|c|l|l}
\hline \multicolumn{1}{c|}{ Grupo } & $\begin{array}{c}\text { Média da variação } \\
\text { total }(\mathbf{m m})\end{array}$ & & \\
\hline I (placa balanceada) & $-0,47$ & $\mathrm{xxXX}$ & \\
\hline II (placa com guia) & 0,65 & $\mathrm{xXXX}$ & $\mathrm{XXXX}$ \\
\hline III (placebo) & 1,00 & & $\mathrm{XXXX}$ \\
\hline
\end{tabular}

Teste ANOVA entre os grupos- $p=0,047$

$x x x x=$ representação da diferença entre os valores, onde a sua permanência na coluna representa alteração não significativa com relação ao período imediatamente anterior, e a sua mudança de coluna representa alteração significativa com relação ao período representado na coluna anterior. 


\subsection{2 - Lateralidade Esquerda}

Os resultados da análise do teste ANOVA não detectou diferenças significativas nos valores dos movimentos de lateralidade esquerda, entre os grupos ( $p=0,845)$. A Tabela 11 apresentam a evolução desta variável, ao longo dos diferentes períodos de avaliação.

Tabela 11- Distribuição média dos valores de lateralidade esquerda (em milímetros) entre os grupos nos diferentes períodos de mensuração.

\begin{tabular}{lccccccc}
\hline \multicolumn{1}{c}{ GRUPO } & Inicial & $\mathbf{7}$ dias & $\mathbf{1 5}$ dias & $\mathbf{1}$ mês & $\mathbf{3}$ meses & $\mathbf{6}$ meses & $\begin{array}{c}\text { Variaçã } \\
\text { o total }\end{array}$ \\
\hline I- Placa balanceada & 9,21 & 9,31 & 9,00 & 8,89 & 9,00 & 9,47 & 0,26 \\
\hline II- Placa com guia & 9,45 & 9,20 & 9,45 & 9,85 & 9,85 & 9,90 & 0,45 \\
\hline III- Placebo & 9,78 & 10,0 & 9,33 & 10,22 & 9,83 & 10,22 & 0,44 \\
\hline Total & 9,48 & 9,51 & 9,4 & 9,65 & 9,56 & 9,86 & 0,38 \\
\hline
\end{tabular}

\subsection{3 - Movimento Protrusivo}

Já os valores relativos ao movimento protrusivo nos diferentes grupos estão representados na Tabela 12. O teste MANOVA não verificou diferenças significativas nos valores de movimento protrusivo entre os grupos $(p=0,13)$.

Tabela 12 - Distribuição média dos valores do movimento protrusivo (em milímetros) entre os grupos nos diferentes períodos de mensuração

\begin{tabular}{lccccccc}
\hline \multicolumn{1}{c}{ GRUPO } & Inicial & 7 dias & 15 dias & 1 mês & 3 meses & $\mathbf{6}$ meses & $\begin{array}{c}\text { Variação } \\
\text { total }\end{array}$ \\
\hline I- Placa balanceada & 6,31 & 6,63 & 6,95 & 6,79 & 6,84 & 7,32 & 1,00 \\
\hline II- Placa com guia & 7,45 & 7,60 & 7,10 & 6,70 & 7,30 & 7,55 & 0,10 \\
\hline III- Placebo & 6,67 & 7,33 & 7,50 & 7,17 & 7,17 & 7,17 & 0,22 \\
\hline Total & 6,81 & 7,18 & 7,18 & 6,90 & 7,10 & 7,35 & 0,44 \\
\hline
\end{tabular}




\section{5 - RUÍDOS ARTICULARES}

Quanto à presença de ruídos articulares, inicialmente, todos os indivíduos apresentavam este sinal clínico. A Tabela 13 apresenta a freqüência da presença e ausência de ruídos articulares nos diferentes grupos, em valores percentuais ao longo dos períodos de avaliação.

Para avaliação inter-grupos, realizou-se o teste Quiquadrado para verificar a associação entre presença e ausência de ruídos articulares e os diferentes grupos, em cada avaliação. Não foi verificada associação significativa estatisticamente em nenhuma das avaliações. Entretanto, pelos valores percentuais, parece haver uma discreta redução no número de indivíduos com ruídos articulares em todos os grupos, sendo um pouco mais nítida no grupo II (placa com guia) (Tabela 13).

Tabela 13- Valores absolutos e percentuais de indivíduos com ruídos articulares, em cada grupo, durante as avaliações.

\begin{tabular}{ccccccc}
\hline & \multicolumn{5}{c}{ Presença de ruídos } \\
\hline Grupo & inicial & $\mathbf{7}$ dias & $\mathbf{1 5}$ dias & $\mathbf{3 0}$ dias & $\mathbf{3}$ meses & $\mathbf{6}$ meses \\
\hline I & 19 & 14 & 16 & 16 & 15 & 16 \\
(placa balanceada) & $100 \%$ & $73,7 \%$ & $84,21 \%$ & $84,2 \%$ & $79,0 \%$ & $84,21 \%$ \\
\hline II & 20 & 16 & 19 & 19 & 14 & 14 \\
(placa com guia) & $100 \%$ & $80,0 \%$ & $95,0 \%$ & $95,0 \%$ & $70,0 \%$ & $70,0 \%$ \\
\hline III & 18 & 17 & 17 & 16 & 14 & 15 \\
(placebo) & $1100 \%$ & $94,4 \%$ & $94,4 \%$ & $88,9 \%$ & $77,8 \%$ & $83,3 \%$ \\
\hline
\end{tabular}




\section{6 - DOR ARTICULAR À PALPAÇÃO}

Em nenhuma das situações (ATM esquerda ou direita e aspectos lateral ou posterior), houve diferença significativa entre os grupos, pelo teste de Kruskal-Wallis.

Entretanto, houve variações significativas, ao longo do tempo, para as diferentes mensurações (aspectos lateral e posterior das ATMs direita e esquerda), dentro do mesmo grupo.

\subsection{1 - Aspecto Lateral da ATM direita}

Por meio do teste de Friedman, verificou-se a presença de diferenças significativas $(p<0,001)$ entre os valores de dor à palpação no aspecto lateral da ATM direita, ao longo das avaliações, para todos os grupos. A fim de localizar em que momento ocorreram as alterações, realizou-se o teste de Student-Newman-Keuls em cada situação para cada grupo.

Para o grupo I (placa balanceada) o teste demonstrou que, logo na primeira reavaliação, houve significativa redução na dor à palpação. Entretanto, a partir daí as alterações não foram mais significativas com relação à segunda avaliação, (Tabela 14). 
Tabela 14- Valores dos escores médios de dor à palpação do aspecto lateral da ATM direita e sua variação ao longo das avaliações (Friedman - Student-Newman-Keuls) para o grupo I (placa balanceada)

\begin{tabular}{|c|c|c|c|c|c|}
\hline Tempo & Escore médio & $25 \%$ & $75 \%$ & & \\
\hline Inicial & 1,0 & 1,0 & 2,0 & $\mathrm{XXXX}$ & \\
\hline 7 dias & 1,0 & 0,0 & 1,0 & & $x x x$ \\
\hline 15 dias & 0,0 & 0,0 & 1,0 & & $x x x$ \\
\hline 1 mês & 0,0 & 0,0 & 0,0 & & $x x x$ \\
\hline 3 meses & 0,0 & 0,0 & 0,0 & & $x x x x$ \\
\hline 6 meses & 0,0 & 0,0 & 0,0 & & $x x x$ \\
\hline
\end{tabular}

$x x x x=$ representação da diferença entre os valores, onde a sua permanência na coluna representa alteração não significativa com relação ao período imediatamente anterior, e a sua mudança de coluna representa alteração significativa com relação ao período representado na coluna anterior.

Para o grupo II (placa com guia houve redução significativa da dor à palpação na primeira reavaliação (7 dias) e segunda reavaliação (15 dias) (Tabela 15)

Tabela 15- Valores dos escores médios de dor à palpação do aspecto lateral da ATM direita e sua variação ao longo das avaliações (Friedman - Student-Newman-Keuls) para o grupo II (placa com guia)

\begin{tabular}{|c|c|c|c|c|c|c|}
\hline Tempo & $\begin{array}{l}\text { Escore } \\
\text { médio }\end{array}$ & $25 \%$ & $75 \%$ & & & \\
\hline Inicial & 2,0 & 1,0 & 2,0 & $x X X X$ & & \\
\hline 7 dias & 1,0 & 1,0 & 2,0 & & $x x x x$ & \\
\hline 15 dias & 1,0 & 0,0 & 1,5 & & & $X X X X$ \\
\hline 1 mês & 0,0 & 0,0 & 1,0 & & & XXXX \\
\hline 3 meses & 0,0 & 0,0 & 1,0 & & & XXXX \\
\hline 6 meses & 0,0 & 0,0 & 1,0 & & & XXXX \\
\hline
\end{tabular}


E para o grupo III (placebo houve redução significativa da dor à palpação na primeira reavaliação (1 semana), permanecendo sem alterações (Tabela 16).

Tabela 16- Valores dos escores médios de dor à palpação do aspecto lateral da ATM direita e sua variação ao longo das avaliações (Friedman - Student-Newman-Keuls) para o grupo III (placebo)

\begin{tabular}{ccccc}
\hline Tempo & $\begin{array}{c}\text { Escore } \\
\text { médio }\end{array}$ & $\mathbf{2 5 \%}$ & $\mathbf{7 5 \%}$ & XXXX \\
\hline Inicial & 1,5 & 1,0 & 2,0 & XXXX \\
\hline 7 dias & 1,0 & 0,0 & 2,0 & XXXX \\
\hline 15 dias & 1,0 & 0,0 & 2,0 & XXXX \\
\hline 1 mês & 0,0 & 0,0 & 1,0 & XXXX \\
\hline $\mathbf{6}$ meses & 0,0 & 0,0 & 1,0 & 2,0 \\
\hline meses & 0,0 & 0,0 & representa \\
alteração não significativa com relação ao período imediatamente anterior, e a sua mudança de coluna \\
representa alteração significativa com relação ao período representado na coluna anterior.
\end{tabular}

A Figura 7 apresenta, de forma gráfica, as informações anteriormente expostas.

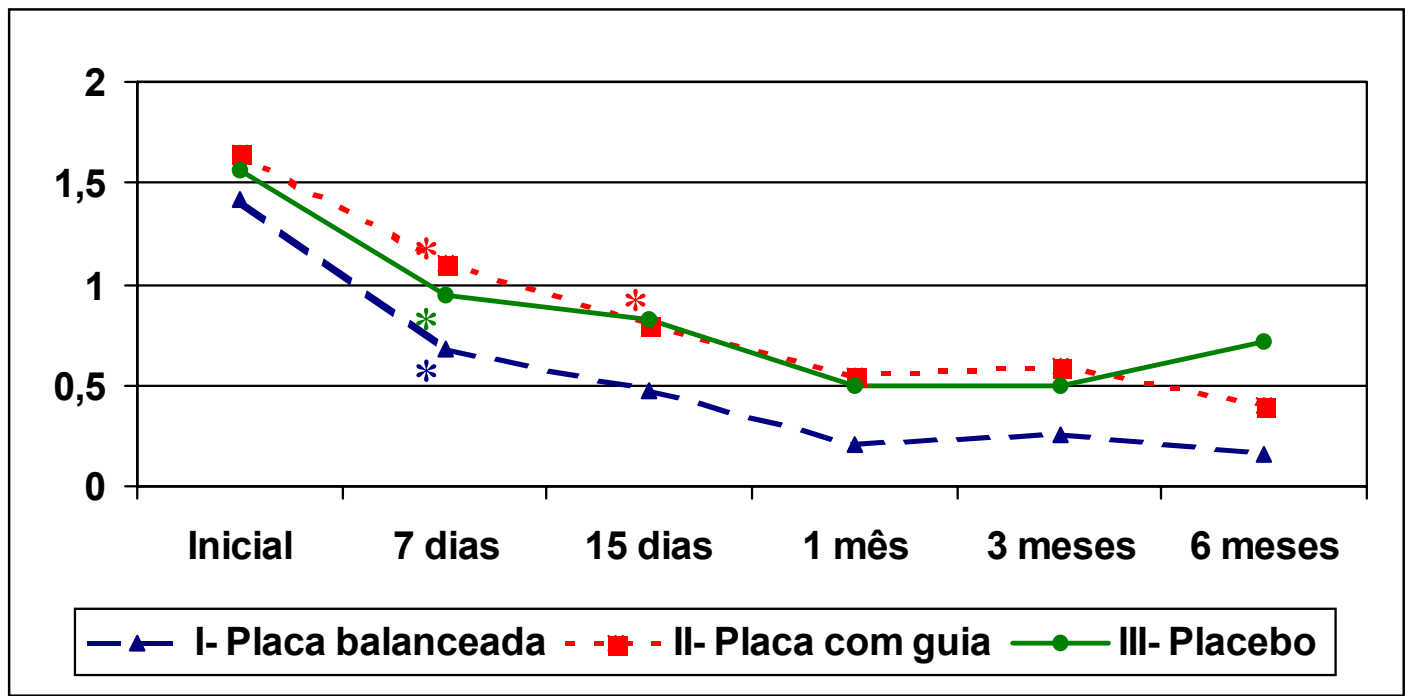

Figura 7- Variação dos valores de dor à palpação no aspecto lateral da ATM direita, ao longo do tempo. 


\subsection{2 - Aspecto lateral da ATM esquerda}

Para o grupo I (placa balanceada), houve redução significativa da dor à palpação logo na primeira reavaliação (7 dias), seguida de nova redução significativa na terceira reavaliação (1 mês) (Tabela 17).

Tabela 17- Valores dos escores médios de dor à palpação do aspecto lateral da ATM esquerda e sua variação ao longo das avaliações (Friedman - Student-Newman-Keuls) para o grupo I (placa balanceada)

\begin{tabular}{|c|c|c|c|c|c|c|}
\hline Tempo & Escore médio & $25 \%$ & $75 \%$ & & & \\
\hline Inicial & 2,0 & 1,0 & 2,0 & $x X X X$ & & \\
\hline 7 dias & 1,0 & 0,0 & 2,0 & & $x x x x$ & \\
\hline 15 dias & 1,0 & 0,0 & 1,0 & & $\mathrm{XXXX}$ & \\
\hline 1 mês & 0,0 & 0,0 & 0,0 & & & $x x x x$ \\
\hline 3 meses & 0,0 & 0,0 & 0,75 & & & $x x x x$ \\
\hline 6 meses & 0,0 & 0,0 & 0,0 & & & $X X X X$ \\
\hline
\end{tabular}

* = significativo estatisticamente com relação ao período imediatamente anterior

** = significativo estatisticamente com relação ao período representado apenas na coluna anterior $x x x x=$ representação da diferença entre os valores, onde a sua permanência na coluna representa alteração não significativa com relação ao período imediatamente anterior, e a sua mudança de coluna representa alteração significativa com relação ao período representado na coluna anterior.

Para o grupo II (placa com guia), verificou-se redução significativa da dor à palpação na primeira reavaliação (7 dias), permanecendo sem alterações significativas (Tabela 18). 
Tabela 18- Valores dos escores médios de dor à palpação do aspecto lateral da ATM esquerda e sua variação ao longo das avaliações (Friedman - Student-Newman-Keuls) para o grupo II (placa com guia)

\begin{tabular}{|c|c|c|c|c|c|}
\hline Tempo & $\begin{array}{l}\text { Escore } \\
\text { médio }\end{array}$ & $25 \%$ & $75 \%$ & & \\
\hline Inicial & 1,5 & 1,0 & 2,0 & $x X X X$ & \\
\hline 7 dias & 1,0 & 0,5 & 2,0 & & $x x x x$ \\
\hline 15 dias & 0,5 & 0,0 & 1,5 & & $x x x x$ \\
\hline 1 mês & 0,0 & 0,0 & 1,0 & & $x x x x$ \\
\hline 3 meses & 0,0 & 0,0 & 1,0 & & $x x x x$ \\
\hline 6 meses & 0,0 & 0,0 & 1,0 & & $x X X X$ \\
\hline
\end{tabular}

$x x x x=$ representação da diferença entre os valores, onde a sua permanência na coluna representa alteração não significativa com relação ao período imediatamente anterior, e a sua mudança de coluna representa alteração significativa com relação ao período representado na coluna anterior.

E para o grupo III (placebo), o teste de Sudent-Newman-

Keuls demonstrou que houve redução significativa da dor à palpação na primeira reavaliação (7 dias), mantendo-se sem alterações significativas (Tabela 19).

Tabela 19- Valores dos escores médios de dor à palpação do aspecto lateral da ATM esquerda e sua variação ao longo das avaliações (Friedman - Student-Newman-Keuls) para o grupo III (placebo)

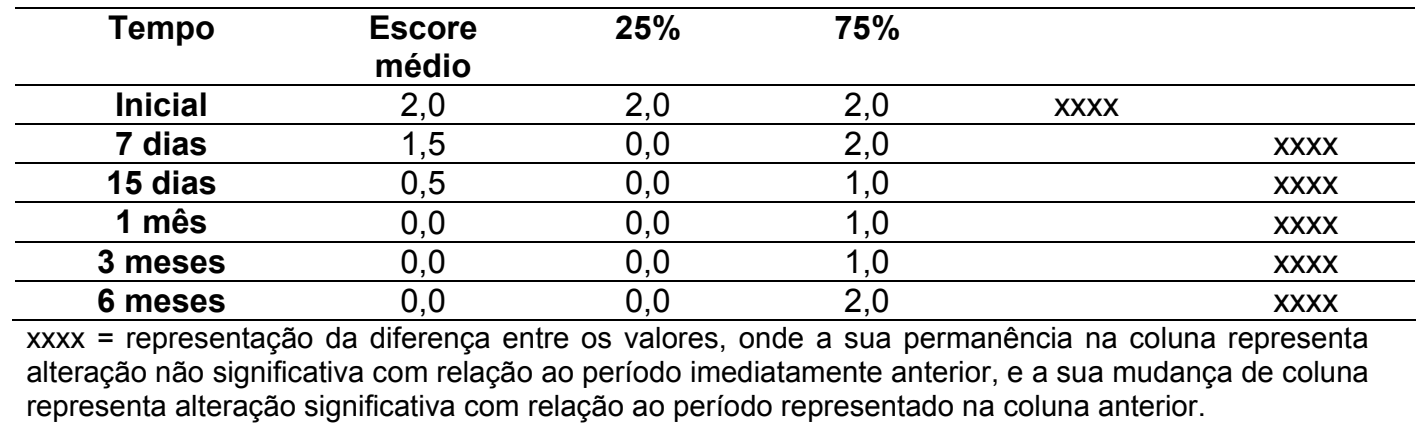


A Figura 8 apresenta, em resumo, as informações anteriormente expostas.

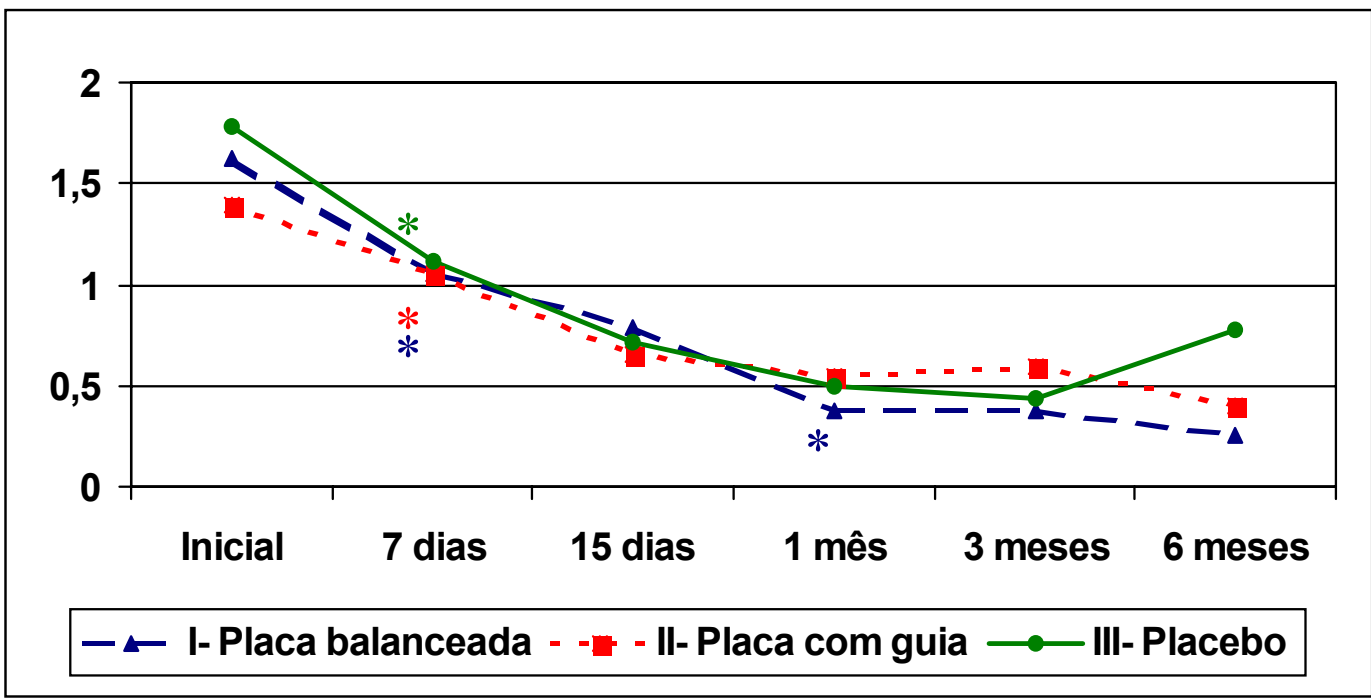

Figura 8- Variação dos valores de dor à palpação no aspecto lateral da ATM esquerda, ao longo do tempo

\subsection{3 - Aspecto posterior da ATM direita}

Com relação ao grupo I (placa balanceada), o teste de Sudent-Newman-Keuls demonstrou que houve redução significativa da dor à palpação na primeira reavaliação (7 dias) seguida de nova redução significativa na segunda reavaliação (15 dias) (Tabela 20). 
Tabela 20- Valores dos escores médios de dor à palpação do aspecto posterior da ATM direita e sua variação ao longo das avaliações (Friedman - Student-Newman-Keuls) para o grupo I (placa balanceada)

\begin{tabular}{|c|c|c|c|c|c|c|}
\hline Tempo & $\begin{array}{l}\text { Escore } \\
\text { médio }\end{array}$ & $25 \%$ & $75 \%$ & & & \\
\hline Inicial & 2,0 & 1,250 & 2,0 & $x x x x$ & & \\
\hline 7 dias & 1,0 & 1,0 & 2,0 & & $x x x x$ & \\
\hline 15 dias & 1,0 & 0,0 & 2,0 & & & $x x x x$ \\
\hline 1 mês & 0,0 & 0,0 & 1,0 & & & $\mathrm{XXXX}$ \\
\hline 3 meses & 0,0 & 0,0 & 1,0 & & & $x x x x$ \\
\hline 6 meses & 0,0 & 0,0 & 1,0 & & & $x X X X$ \\
\hline
\end{tabular}

Com relação ao grupo II (placa com guia), verificou-se redução significativa da dor à palpação na primeira (7 dias), segunda (15 dias) e última (6 meses) reavaliações (Tabela 21).

Tabela 21- Valores dos escores médios de dor à palpação do aspecto posterior da ATM direita e sua variação ao longo das avaliações (Friedman - Student-Newman-Keuls) para o grupo II (placa com guia)

\begin{tabular}{cccccc}
\hline Tempo & $\begin{array}{c}\text { Escore } \\
\text { médio }\end{array}$ & $\mathbf{2 5 \%}$ & $\mathbf{7 5 \%}$ & & \\
\hline Inicial & 2,0 & 1,5 & 2,0 & XXXX & \\
\hline 7 dias & 2,0 & 1,0 & 2,0 & XXXX & \\
\hline 15 dias & 1,0 & 0,0 & 1,0 & & XXXX \\
\hline 1 mês & 1,0 & 0,0 & 2,0 & XXXX \\
\hline 3 meses & 1,0 & 0,0 & 2,0 & & XXXX \\
\hline 6 meses & 0,0 & 0,0 & 1,0 & & \\
\hline
\end{tabular}

xxxx = representação da diferença entre os valores, onde a sua permanência na coluna representa alteração não significativa com relação ao período imediatamente anterior, e a sua mudança de coluna representa alteração significativa com relação ao período representado na coluna anterior. 
Para o grupo III (placebo), o teste de Sudent-Newman-Keuls demonstrou que houve redução significativa da dor à palpação na primeira reavaliação (7 dias), mantendo-se sem mais alterações (Tabela 22)

Tabela 22- Valores dos escores médios de dor à palpação do aspecto posterior da ATM direita e sua variação ao longo das avaliações (Friedman - Student-Newman-Keuls) para o grupo III (placebo)

\begin{tabular}{|c|c|c|c|c|c|}
\hline Tempo & $\begin{array}{l}\text { Escore } \\
\text { médio }\end{array}$ & $25 \%$ & $75 \%$ & & \\
\hline Inicial & 2,0 & 1,0 & 3,0 & $x X X X$ & \\
\hline 7 dias & 2,0 & 1,0 & 2,0 & & XXXX \\
\hline 15 dias & 2,0 & 0,0 & 2,0 & & $x x x x$ \\
\hline 1 mês & 1,0 & 0,0 & 2,0 & & XXXX \\
\hline 3 meses & 1,0 & 0,0 & 2,0 & & XXXX \\
\hline 6 meses & 1,0 & 0,0 & 2,0 & & $X X X X$ \\
\hline
\end{tabular}

A Figura 9 apresenta, em resumo, as informações anteriormente expostas. 


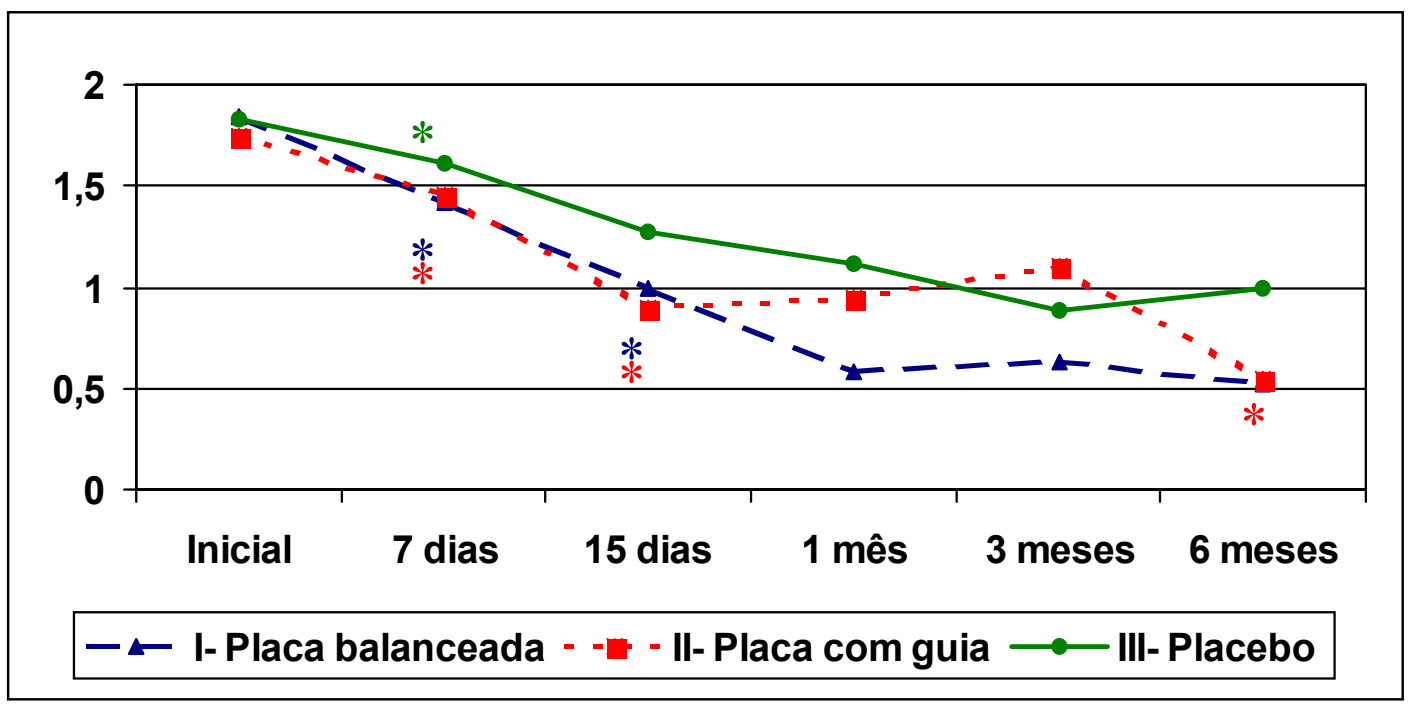

Figura 9- Valores dos valores de dor à palpação no aspecto posterior da ATM direita, ao longo do tempo

\subsection{4 - Aspecto Posterior da ATM Esquerda}

Para o grupo I (placa balanceada), ocorreu redução significativa da dor à palpação apenas a partir da terceira reavaliação (1 mês), permanecendo inalterada nas outras reavaliações (Tabela 23).

Tabela 23- Valores dos escores médios de dor à palpação do aspecto posterior da ATM esquerda e sua variação ao longo das avaliações (Friedman - Student-Newman-Keuls) para o grupo I (placa balanceada)

\begin{tabular}{cccccc}
\hline Tempo & Escore médio & $\mathbf{2 5 \%}$ & $\mathbf{7 5 \%}$ & & \\
\hline Inicial & 2,0 & 1,25 & 2,0 & XXXX & \\
\hline 7 dias & 2,0 & 1,25 & 2,0 & XXXX & \\
\hline 15 dias & 2,0 & 1,0 & 2,0 & XXXX & \\
\hline 1 mês & 1,0 & 0,25 & 1,75 & & XXXX \\
\hline 3 meses & 1,0 & 0,0 & 1,75 & & XXXX \\
\hline 6 meses & 0,0 & 0,0 & 1,0 & & \\
\hline
\end{tabular}

$x x x x=$ representação da diferença entre os valores, onde a sua permanência na coluna representa alteração não significativa com relação ao período imediatamente anterior, e a sua mudança de coluna representa alteração significativa com relação ao período representado na coluna anterior. 
No grupo II (placa com guia) as alterações significativas só ocorreram na quarta (3 meses) e última (6 meses) reavaliações (Tabela 24).

Tabela 24- Valores dos escores médios de dor à palpação do aspecto posterior da ATM esquerda e sua variação ao longo das avaliações (Friedman - Student-Newman-Keuls) para o grupo II (placa com guia)

\begin{tabular}{|c|c|c|c|c|c|}
\hline Tempo & $\begin{array}{l}\text { Escore } \\
\text { médio }\end{array}$ & $25 \%$ & $75 \%$ & & \\
\hline Inicial & 2,0 & 1,0 & 2,0 & $X X X X$ & \\
\hline 7 dias & 2,0 & 1,0 & 2,0 & XXXX & \\
\hline 15 dias & 1,0 & 0,5 & 2,0 & XXXX & \\
\hline 1 mês & 1,0 & 1,0 & 2,0 & $X X X X$ & \\
\hline 3 meses & 0,5 & 0,0 & 1,0 & & \\
\hline 6 meses & 0,0 & 0,0 & 1,0 & & $x x x x$ \\
\hline
\end{tabular}

$x x x x=$ representação da diferença entre os valores, onde a sua permanência na coluna representa alteração não significativa com relação ao período imediatamente anterior, e a sua mudança de coluna representa alteração significativa com relação ao período representado na coluna anterior.

E para o grupo III (placebo), houve redução significativa da dor à palpação apenas na primeira reavaliação (7 dias), não ocorrendo mais alterações significativas, a partir daí, com relação a este período (Tabela 25).

Tabela 25- Valores dos escores médios de dor à palpação do aspecto posterior da ATM esquerda e sua variação ao longo das avaliações (Friedman - Student-Newman-Keuls) para o grupo III (placebo)

\begin{tabular}{|c|c|c|c|c|c|}
\hline Tempo & $\begin{array}{l}\text { Escore } \\
\text { médio }\end{array}$ & $25 \%$ & $75 \%$ & & \\
\hline Inicial & 2,0 & 2,0 & 2,0 & $x X X X$ & \\
\hline 7 dias & 2,0 & 1,0 & 2,0 & & $x x x x$ \\
\hline 15 dias & 1,5 & 0,0 & 2,0 & & $x x x x$ \\
\hline 1 mês & 0,5 & 0,0 & 2,0 & & $x x x x$ \\
\hline 3 meses & 1,0 & 0,0 & 2,0 & & $x X X X$ \\
\hline 6 meses & 1,0 & 0,0 & 2,0 & & $x X X X$ \\
\hline
\end{tabular}


A Figura 10 apresenta, em resumo, as informações anteriormente expostas.

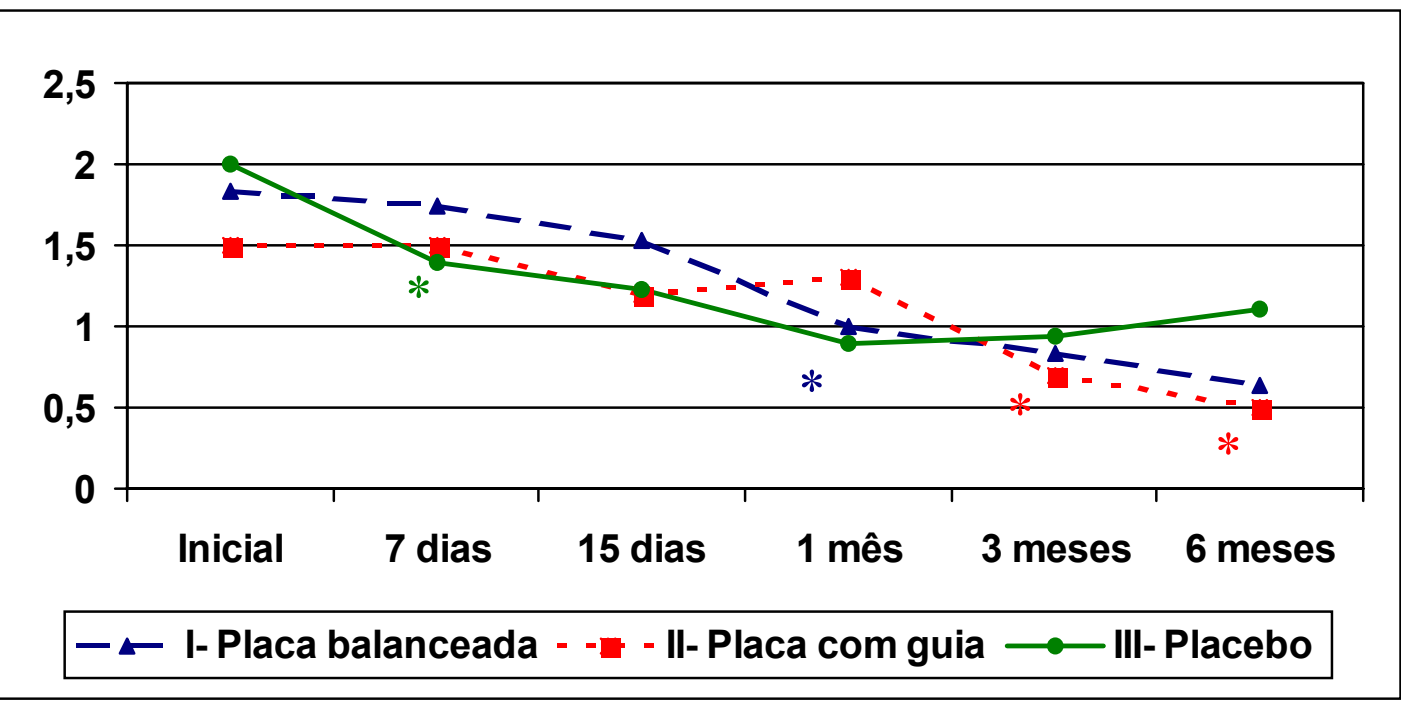

Figura 10- Valores de dor à palpação no aspecto posterior da ATM esquerda, ao longo das avaliações.

\section{7 - DOR MUSCULAR À PALPAÇÃO}

\subsection{1 - Avaliação inter-grupos}

A Tabela 26 apresenta os valores de "p", após realização do teste de Kruskal-Wallis para verificar diferenças nos valores das variações de dor à palpação (músculos temporais esquerdo e direito, porções anterior, média e posterior e músculos masséteres esquerdo e direito, porção profunda e origem, corpo e inserção da porção superficial), entre os diferentes grupos. 
Tabela 26- Valores de "p" (Kruskal-Wallis) da avaliação das médias de variação nos escores de dor à palpação muscular

\begin{tabular}{|c|c|c|c|}
\hline Músculo & lado & porção & $p$ \\
\hline \multirow{6}{*}{ Músculo temporal } & \multirow{3}{*}{ Direito } & Porção anterior & 0,068 \\
\hline & & Porção média & 0,146 \\
\hline & & Porção posterior & 0,849 \\
\hline & \multirow{3}{*}{ Esquerdo } & Porção anterior & $0,007^{*}$ \\
\hline & & Porção média & 0,588 \\
\hline & & Porção posterior & 0,492 \\
\hline \multirow{8}{*}{ Músculo masseter } & \multirow{4}{*}{ Direito } & Profundo & 0,108 \\
\hline & & Superficial origem & 0,164 \\
\hline & & Superficial corpo & 0,076 \\
\hline & & Superficial inserção & 0,307 \\
\hline & \multirow{4}{*}{ Esquerdo } & Profundo & 0,096 \\
\hline & & Superficial origem & 0,092 \\
\hline & & Superficial corpo & $0,003^{*}$ \\
\hline & & Superficial inserção & 0,377 \\
\hline
\end{tabular}

* = estatisticamente significativo

O teste de Dunn verificou diferença estatisticamente significativa entre os grupos II (placa com guia) e III (placebo), com relação à dor à palpação na porção anterior do músculo temporal esquerdo ( $\mathrm{p}=$ 0,007), sendo que o grupo II apresentou redução na dor significativamente maior do que o grupo III, (-1,20 e 0,0, respectivamente) (Tabela 27).

Tabela 27- Distribuição das médias dos valores de dor à palpação na porção anterior do músculo temporal esquerdo

\begin{tabular}{|c|c|c|c|c|c|c|c|}
\hline GRUPO & Inicial & 7 dias & 15 dias & 1 mês & 3 meses & 6 meses & $\begin{array}{c}\text { Variação } \\
\text { total }\end{array}$ \\
\hline I- Placa balanceada & 0,95 & 1,21 & 1,05 & 0,42 & 0,47 & 0,26 & $-0,68$ \\
\hline II- Placa com guia & 1,50 & 1,00 & 1,25 & 1,05 & 0,60 & 0,30 & $-1,20$ \\
\hline III- Placebo & 1,06 & 1,22 & 1,11 & 1,06 & 1,00 & 0,89 & 0,00 \\
\hline Total & 1,17 & 1,14 & 1,12 & 0,84 & 0,69 & 0,48 & $-0,63$ \\
\hline
\end{tabular}


E também houve diferença significativa entre os grupos I (placa balanceada) e III (placebo), com relação à dor à palpação na origem do músculo masseter esquerdo $(p=0,003)$, sendo que o grupo I apresentou redução na dor significativamente maior do que o grupo III, (-1,47 e 10,28, respectivamente) (Tabela 28).

Tabela 28- Distribuição das médias dos valores de dor à palpação do corpo do músculo masséter esquerdo

\begin{tabular}{|c|c|c|c|c|c|c|c|}
\hline GRUPO & Inicial & 7 dias & 15 dias & 1 mês & 3 meses & 6 meses & $\begin{array}{c}\text { Variação } \\
\text { total }\end{array}$ \\
\hline I- Placa balanceada & 1,89 & 1,95 & 1,05 & 1,00 & 0,84 & 0,42 & $-1,47$ \\
\hline II- Placa com guia & 2,00 & 1,60 & 1,60 & 1,30 & 1,00 & 1,00 & $-1,00$ \\
\hline III- Placebo & 1,61 & 1,67 & 1,50 & 1,61 & 1,33 & 1,33 & $-0,28$ \\
\hline Total & 1,83 & 1,74 & 1,38 & 1,30 & 1,06 & 0,92 & $-0,92$ \\
\hline
\end{tabular}

Nas porções restantes dos músculos avaliados não houve diferença estatisticamente significativa.

\section{8 - RELATO DOS PACIENTES}

As Tabelas 29, 30 e 31 mostram os resultados obtidos quando analisadas as respostas dos pacientes quanto à alteração de ruídos, mudança de mordida e conforto com a placa, ao longo de todas as avaliações.

Com relação ao ruído articular, nota-se que, ao longo das avaliações, o valor percentual de respostas "manteve-se" diminuiu ao passo 
que o valor de respostas "alterou para melhor" aumentou, para os grupos I (placa balanceada) e II (placa com guia). Para o grupo III, parece haver uma constância nos valores percentuais. Confirmando esta tendência, verificouse que na $3^{a}$ avaliação ( 1 mês), ocorreu associação positiva pelo teste do Qui-quadrado ( $p=0,0468$ ) para o grupo I (placa balanceada) e a resposta "alterou para melhor", em que $73,7 \%$ responderam que a placa balanceada havia reduzido os ruídos articulares; e para o grupo III (placebo) e a resposta "manteve-se", em que 66,7\% responderam que não houve alteração dos ruídos articulares com o uso da placa placebo. $\mathrm{Na} 5^{\mathrm{a}}$ avaliação (6 meses), novamente ocorreu associação pelo teste Qui-quadrado ( $p=0,021)$ para o grupo I (placa balanceada) e a resposta "alterou para melhor" (com 79,0\%); para o grupo II (placa com guia) e a resposta "alterou para melhor" (com $65,0 \%$ ) e para o grupo III (placebo) e a resposta "manteve-se" (com 66,7\%) (Tabela 29). 
Tabela 29- Valores absolutos e percentuais de relato quanto à alteração de ruídos nos diferentes períodos de mensuração

\begin{tabular}{|c|c|c|c|c|c|c|c|c|c|c|c|c|c|c|c|c|}
\hline \multirow[b]{2}{*}{ Grupo } & \multicolumn{5}{|c|}{ Manteve-se } & \multicolumn{5}{|c|}{ Alterou para melhor } & \multicolumn{5}{|c|}{ Alterou para pior } & \multirow[t]{2}{*}{ n (\%) } \\
\hline & $1^{\mathrm{a}}$ & $2^{a}$ & $3^{a}$ & $4^{a}$ & $5^{a}$ & $1^{\mathrm{a}}$ & $2^{a}$ & $3^{a}$ & $4^{a}$ & $5^{a}$ & $1^{a}$ & $2^{\mathrm{a}}$ & $3^{a}$ & $4^{a}$ & $5^{a}$ & \\
\hline \multirow[t]{2}{*}{ I } & 9 & 7 & 5 & 6 & 3 & 10 & 12 & $14^{*}$ & 12 & $15^{*}$ & 0 & 0 & 0 & 1 & 1 & 19 \\
\hline & $47,4 \%$ & $36,8 \%$ & $26,3 \%$ & $31,6 \%$ & $15,8 \%$ & $52,6 \%$ & $63,2 \%$ & $73,7 \%$ & $63,2 \%$ & $79,0 \%$ & & & & $5,3 \%$ & $5,3 \%$ & $100 \%$ \\
\hline \multirow[t]{2}{*}{ II } & 11 & 9 & 10 & 8 & 7 & 9 & 10 & 10 & 12 & $13^{*}$ & 0 & 1 & 0 & 0 & 0 & 20 \\
\hline & $55,0 \%$ & $45,0 \%$ & $50,0 \%$ & $40,0 \%$ & $35,0 \%$ & $45,0 \%$ & $50,0 \%$ & $50,0 \%$ & $60,0 \%$ & $65,0 \%$ & & $5 \%$ & & & & $100 \%$ \\
\hline \multirow[t]{2}{*}{ III } & 14 & 12 & $12^{*}$ & 11 & $12^{*}$ & 4 & 6 & 6 & 6 & 5 & 0 & 0 & 0 & 0 & 0 & 18 \\
\hline & $77,4 \%$ & $66,7 \%$ & $66,7 \%$ & $61,1 \%$ & $66,7 \%$ & $22,2 \%$ & $33,3 \%$ & $33,3 \%$ & $33,3 \%$ & $27,9 \%$ & & & & & & $100 \%$ \\
\hline \multirow[t]{2}{*}{ Total } & 34 & 28 & 27 & 23 & 22 & 23 & 28 & 30 & 30 & 33 & 0 & 1 & 0 & 1 & 1 & 57 \\
\hline & $59,6 \%$ & $49,1 \%$ & $47,4 \%$ & $41,1 \%$ & $39,3 \%$ & $40,4 \%$ & $49,1 \%$ & $52,6 \%$ & $53,6 \%$ & $57,9 \%$ & & $1,75 \%$ & & $1,75 \%$ & $1,75 \%$ & $100 \%$ \\
\hline
\end{tabular}

$1^{\mathrm{a}}$ avaliação $=7$ dias; $2^{\mathrm{a}}$ avaliação $=15$ dias; $3^{\mathrm{a}}$ avaliação $=1$ mês; $4^{\mathrm{a}}$ avaliação $=3$ meses; $5^{\mathrm{a}}$ avaliação $=6$ meses

* = estatisticamente significativo 
Com relação às respostas de alteração oclusal, apesar de o teste Qui-quadrado não haver demonstrado qualquer associação entre os grupos e as respostas, observa-se, de forma mais discreta, o mesmo padrão descrito para alteração de ruído. Em que nos grupos I (placa balanceada) e II (placa com guia), parece haver um aumento nos valores de respostas "alterou para melhor" e para o grupo III (placebo) os valores parecem não se alterar ao longo das avaliações (Tabela 30).

Com relação ao conforto, o teste Qui-quadrado mostrou presença de associação em 6 momentos, na $1^{a}(p=0,025), 2^{a}(p=0,03)$ e $3^{a}(p=0,020)$ reavaliações, nas quais houve associação positiva com os grupos I (placa balanceada) e II (placa com guia) e a resposta "alterou para melhor". 
Tabela 30- Valores absolutos e percentuais de relato quanto à mudança de mordida nos diferentes períodos de mensuração

\begin{tabular}{|c|c|c|c|c|c|c|c|c|c|c|c|c|c|c|c|c|}
\hline \multirow[b]{2}{*}{ Grupo } & \multicolumn{5}{|c|}{ Manteve-se } & \multicolumn{5}{|c|}{ Alterou para melhor } & \multicolumn{5}{|c|}{ Alterou para pior } & \multirow[t]{2}{*}{ n (\%) } \\
\hline & $1^{\mathrm{a}}$ & $2^{a}$ & $3^{a}$ & $4^{a}$ & $5^{a}$ & $1^{a}$ & $2^{a}$ & $3^{a}$ & $4^{a}$ & $5^{a}$ & $1^{\mathrm{a}}$ & $2^{a}$ & $3^{a}$ & $4^{a}$ & $5^{a}$ & \\
\hline \multirow[t]{2}{*}{ I } & 15 & 14 & 12 & 11 & 10 & 4 & 5 & 7 & 8 & 9 & 0 & 0 & 0 & 0 & 0 & 19 \\
\hline & $79,0 \%$ & $73,68 \%$ & $63,2 \%$ & $57,9 \%$ & $52,6 \%$ & $21,05 \%$ & $26,3 \%$ & $36,8 \%$ & $42,1 \%$ & $47,4 \%$ & & & & & & $100 \%$ \\
\hline \multirow[t]{2}{*}{ II } & 16 & 16 & 17 & 13 & 12 & 4 & 4 & 3 & 7 & 8 & 0 & 0 & 0 & 0 & 0 & 20 \\
\hline & $80,0 \%$ & $80,0 \%$ & $85,0 \%$ & $65,0 \%$ & $60,0 \%$ & $20,0 \%$ & $20,0 \%$ & $15,0 \%$ & $35,0 \%$ & $40,0 \%$ & & & & & & $100 \%$ \\
\hline \multirow[t]{2}{*}{ III } & 13 & 15 & 15 & 14 & 13 & 5 & 3 & 3 & 4 & 5 & 0 & 0 & 0 & 0 & 0 & 18 \\
\hline & $72,2 \%$ & $83,3 \%$ & $83,3 \%$ & $77,8 \%$ & $72,2 \%$ & $27,8 \%$ & $16,7 \%$ & $16,7 \%$ & $22,2 \%$ & $27,9 \%$ & & & & & & $100 \%$ \\
\hline \multirow[t]{2}{*}{ Total } & 44 & 45 & 44 & 38 & 35 & 9 & 12 & 13 & 19 & 22 & 0 & 0 & 0 & 0 & 0 & 57 \\
\hline & $77,2 \%$ & $78,91 \%$ & $77,2 \%$ & $66,7 \%$ & $61,4 \%$ & $15,8 \%$ & $21,1 \%$ & $22,8 \%$ & $33,7 \%$ & $38,6 \%$ & & & & & & $100 \%$ \\
\hline
\end{tabular}

$1^{\mathrm{a}}$ avaliação $=7$ dias; $2^{\mathrm{a}}$ avaliação $=15$ dias; $3^{\mathrm{a}}$ avaliação $=1$ mês; $4^{\mathrm{a}}$ avaliação $=3$ meses; $5^{\mathrm{a}}$ avaliação $=6$ meses

* = estatisticamente significativo 
Tabela 31- Valores absolutos e percentuais de relato quanto ao conforto com a placa nos diferentes períodos de mensuração

\begin{tabular}{|c|c|c|c|c|c|c|c|c|c|c|c|c|c|c|c|c|}
\hline \multirow[b]{2}{*}{ Grupo } & \multicolumn{5}{|c|}{ Manteve-se } & \multicolumn{5}{|c|}{ Alterou para melhor } & \multicolumn{5}{|c|}{ Alterou para pior } & \multirow[t]{2}{*}{ n (\%) } \\
\hline & $1^{a}$ & $2^{a}$ & $3^{a}$ & $4^{a}$ & $5^{a}$ & $1^{a}$ & $2^{a}$ & $3^{a}$ & $4^{a}$ & $5^{a}$ & $1^{a}$ & $2^{a}$ & $3^{a}$ & $4^{a}$ & $5^{a}$ & \\
\hline \multirow[t]{2}{*}{ I } & 1 & 1 & 0 & 1 & 1 & $18^{*}$ & $18^{*}$ & $18^{*}$ & 14 & 16 & 0 & 0 & 1 & 4 & 2 & 19 \\
\hline & $5,26 \%$ & $5,26 \%$ & $0,0 \%$ & $5,26 \%$ & $5,26 \%$ & $94,7 \%$ & $94,7 \%$ & $94,7 \%$ & $73,7 \%$ & $84,2 \%$ & & & $5,26 \%$ & $21,1 \%$ & $10,5 \%$ & $100 \%$ \\
\hline \multirow[t]{2}{*}{ II } & 2 & 1 & 1 & 1 & 2 & $18^{*}$ & $19^{*}$ & $18^{*}$ & 18 & 18 & 0 & 0 & 1 & 1 & 0 & 20 \\
\hline & $10,0 \%$ & $5,0 \%$ & $5,0 \%$ & $5,0 \%$ & $10,0 \%$ & $90,0 \%$ & $95,0 \%$ & $90,0 \%$ & $90,0 \%$ & $90,0 \%$ & & & $5,0 \%$ & $5,0 \%$ & & $100 \%$ \\
\hline \multirow[t]{2}{*}{ III } & 9 & 8 & 5 & 5 & 5 & 8 & 9 & 10 & 10 & 11 & 1 & 1 & 3 & 3 & 2 & 18 \\
\hline & $44,4 \%$ & $44,4 \%$ & $27,8 \%$ & $27,8 \%$ & $27,8 \%$ & $44,4 \%$ & $50,0 \%$ & $55,6 \%$ & $55,6 \%$ & $61,1 \%$ & $5,56 \%$ & $5,56 \%$ & $16,7 \%$ & $16,7 \%$ & $11,1 \%$ & $100 \%$ \\
\hline \multirow[t]{2}{*}{ Total } & 12 & 10 & 6 & 7 & 8 & 44 & 46 & 46 & 42 & 45 & 1 & 1 & 5 & 8 & 4 & 57 \\
\hline & $21,0 \%$ & $17,5 \%$ & $10,5 \%$ & $12,3 \%$ & $14,0 \%$ & $77,2 \%$ & $80,7 \%$ & $80,7 \%$ & $73,7 \%$ & $78,9 \%$ & $1,75 \%$ & $1,75 \%$ & $8,8 \%$ & $17,0 \%$ & $7,0 \%$ & $100 \%$ \\
\hline
\end{tabular}

\footnotetext{
$1^{\mathrm{a}}$ avaliação $=7$ dias; $2^{\mathrm{a}}$ avaliação $=15$ dias; $3^{\mathrm{a}}$ avaliação $=1$ mês; $4^{\mathrm{a}}$ avaliação $=3$ meses; $5^{\mathrm{a}}$ avaliação $=6$ meses
}

* = estatisticamente significativo 
Discussão 


\section{6 - DISCUSSÃO}

Histórico

Três tipos diferentes de relação oclusal podem ocorrer durante a excursão lateral da mandíbula: oclusão balanceada, oclusão de função em grupo e oclusão protegida pelo canino.

A oclusão balanceada originalmente foi defendida como a chave para se obter uma relação harmoniosa entre a guia condilar e as superfícies oclusais dos dentes durante todas as excursões funcionais.

Uma oclusão balanceada é aquela na qual são mantidos contatos simultâneos e iguais entre as superfícies dos dentes opostos em todo o arco e em todos os movimentos.

Esse conceito foi derivado dos ensinamentos de prótese e consiste em ter os dentes em contato não apenas em intercuspidação máxima, mas também em todas as posições excursivas.

Autores como STUART; STALLARD ${ }^{174}$ e SCHYLER ${ }^{157}$ observaram que, apesar desses contatos terem sido essenciais para a estabilidade das próteses totais, eles eram transmitidos para a dentição natural, causando envolvimento periodontal e desgaste excessivo ou desordens temporomandibulares. 
Diante disso, SCHYLER ${ }^{158}$ e outros pesquisadores começaram a substituir a oclusão balanceada por oclusão balanceada unilateral ou função em grupo.

A proteção pelo canino e função em grupo foram descritas como formas de oclusão terapêutica na dentição natural, tendo como base o conhecimento teórico e fracasso clínico da oclusão balanceada. A função pelo canino foi definida como a desoclusão pelos caninos de todos os outros dentes em excursões laterais; e função em grupo quando todos, ou parte dos dentes posteriores, juntamente com o canino, contactam durante os mesmos movimentos e também no lado de trabalho.

A base para a teoria da oclusão pelo canino vem da teoria de D'AMICO ${ }^{41}$ em que os caninos agem como "suportes do estresse" para proteger o periodonto e as estruturas de suporte de forças laterais durante os movimentos excursivos.

Outros creditam a vantagem do canino por possuir este uma relação coroa/raiz favorável, de tal forma que qualquer força dirigida contra a coroa é transmitida a seu periodonto sem qualquer ampliação pela alavanca, como também a de possuir uma raiz maior do que as raízes dos dentes adjacentes, oferecendo assim uma área relativamente grande de ligamento periodontal com uma quantidade maior de receptores sensoriais ${ }^{159,175}$.

Um fundamento ainda mais forte para a guia pelo canino é que o mesmo está em uma posição mais favorável do que os dentes posteriores quando os maxilares são considerados como um sistema de 
alavanca. Assim, de acordo com esses princípios, os caninos estariam sujeitos a menor força do que os dentes posteriores durante o contato do dente lateral ${ }^{132,170,174,181 .}$

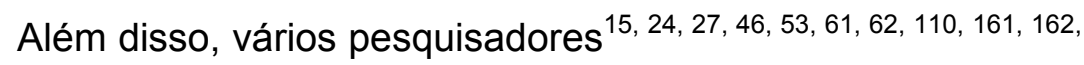
164, 186 realizaram diversos estudos baseados na atividade eletromiográfica dos músculos elevadores da mandíbula (temporal anterior e posterior, masseter), envolvendo o apertamento do canino em diversas posições mandibulares, tanto na máxima intercuspidação habitual como em movimentos excursivos, encontrando uma menor atividade dos músculos.

Já a teoria da função em grupo tem sido suportada por ALEXANDER $^{4}$ 1967; O'LEARY ${ }^{135}$, 1972, e pelas idéias de SCHUYLER ${ }^{157}$ sobre dissipação de forças oclusais. Os que advogam essa condição oclusal, fundamentaram-se num princípio da física que diz: "quanto maior o número de dentes que suporte a carga, menor carga será distribuída para cada dente". Além do que, há trabalhos ${ }^{175}$ também mostrando uma redução de atividades dos músculos de mastigação por essa função em grupo quando a atividade eletromiográfica é medida. Entretanto, esse método já não é considerado um parâmetro de avaliação nos resultados de tratamento dos sinais e sintomas de desordens temporomandibulares, conforme serão discutidos mais adiante.

Para SPEAR ${ }^{170}$, qualquer sistema guia em função em grupo aumenta, em última análise, não só a atividade muscular, mas também a 
carga real sentida entre os dentes quanto mais posteriores forem os contatos.

Dessa maneira, OKESON ${ }^{132}$ preconiza que, caso seja necessário uma função em grupo, que ela seja feita até a cúspide mesial do $1^{\circ}$ molar devido ao aumento de força que pode ser colocada quando eles se aproximam do eixo de rotação e das forças vetoriais (músculos elevadores da mandíbula). Para SPEAR ${ }^{170}$, o acréscimo de pré-molares e da mesial de um molar para o padrão excursivo lateral distribui a carga que irá apenas para os caninos ou dentes anteriores, o que pode ser vantajoso quando os dentes anteriores são peridontalmente incapazes de lidar com os níveis de cargas e oriundos dos movimentos excursivos laterais.

Portanto, como se pode perceber, ambas as teorias foram propostos como excelentes protetores do sistema estomatognático, embora ainda haja pouca evidência científica para encorajar a idéia de um desses esquemas oclusais ser superior ao outro $35,88,115,116,155,175$.

\section{Placas Oclusais}

O uso de placas oclusais é a forma mais universalmente aceita de tratamento sobre os sinais e sintomas de $\mathrm{DTM}^{35,42,63,90,109,151,182 .}$ Relatos clínicos sugerem que os aparelhos de estabilização são úteis no

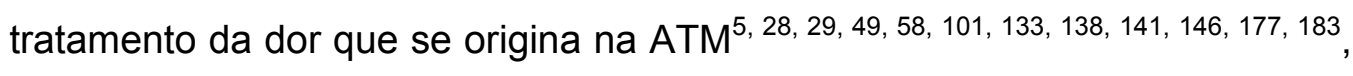

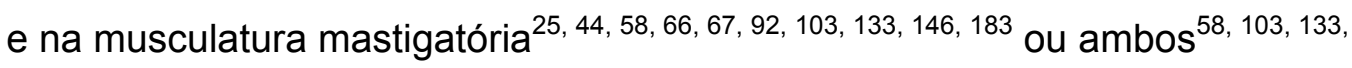


146. Entretanto, ainda não existe um consenso sobre a mecânica de ação ou

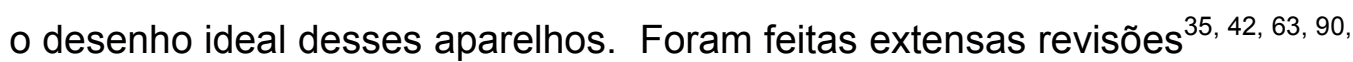
109, 151, 172, 182 sobre o assunto e observaram-se um grande número de desenhos de placa, teorias conflitantes de seu uso e uma falta de conhecimento em relação à ação terapêutica dos aparelhos. CLARK ${ }^{35}$, por exemplo, relatou que os pacientes freqüentemente demonstram melhora com diferentes tipos de placas.

Diversos estudos compararam desenhos diferentes de placa sobre a efetividade no tratamento das DTMs ${ }^{5,43,46,65,103,104,111,113,142,149,150 .}$ POSSELT; WOLFF ${ }^{142}$, por exemplo, avaliaram 3 tipos de placas diferentes: placa de Hawley, resiliente e resina acrílica rígida (estabilizadora), em indivíduos com problemas na ATM, e não chegaram a conclusões definitivas com relação a um tipo ter sido melhor que o outro. Entretanto, houve uma tendência de melhores resultados quando a placa estabilizadora foi usada no tratamento das desordens temporomandibulares.

Outros ${ }^{113}$ pesquisaram placas com diferentes espessuras e chegaram à conclusão de que placas mais finas não foram as mais efetivas no alívio dos sintomas. Alguns pacientes que receberam placas mais espessas $(8 \mathrm{~mm})$ realmente sentiram-se melhores que aqueles que usaram placas mais finas $(1 \mathrm{~mm})$. Dessa forma, a crença clínica, comumente mantida, de que a placa deve ser feita numa menor espessura, não foi sustentada. 
E, finalmente, a grande maioria dos estudos compara as placas estabilizadoras com as placas de reposicionamento anterior (com funções terapêuticas diametralmente opostas), por serem também placas de grande ação terapêutica, principalmente, nos desarranjos internos da ATM $^{103,104,151,166}$.

Como se pode notar, não se chegou, ainda, a uma conclusão de qual desenho seria mais efetivo no tratamento das DTMs. Isso se deve a vários motivos. Talvez por falta de estudos que não seguiram muitos dos procedimentos considerados essenciais para um controle clínico, como a presença de um grupo controle, métodos de registro padronizados, aleatoriedade da amostra, tamanho da amostra, dados coletados e análise com condições às cegas, etc.

Isso fez com que diversas hipóteses fossem formuladas, de como a placa realmente agiria na solução (na melhora) dos sinais e sintomas da DTM. Como GREEN e LASKIN $^{67}$, que consideraram as desarmonias ou irregularidades oclusais como o fator etiológico primário responsável pelo deslocamento mandibular ou desequilíbrio muscular. Assim, a utilização da placa faz com que haja um melhor relacionamento dentário, seguido por uma melhora da função muscular.

Já KURITA; KURASHINA; KOTANI ${ }^{93}$, acredita que os aparelhos oclusais devem ser utilizados para reduzir as forças nos tecidos retrodiscais em pacientes com deslocamento permanente de disco. 
MANNS et al $^{113}$, por outro lado, acreditam que o sucesso das placas na redução do mioespasmo deve-se ao relaxamento muscular produzido por uma redução da atividade EMG dos músculos da mastigação.

Já KURITA; IKEDA; KURASHINA ${ }^{92}$ relatam que as placas têm o efeito de normalizar as forças oclusais por reduzirem a hiperatividade e a assimetria na atividade dos músculos elevadores da mandíbula; enquanto HULMGREN; SHEIKHOLESLAM; RIISE ${ }^{75}$ opinam que, provavelmente, o mecanismo terapêutico delas seja relacionado a fatores que modificam e reduzem a atividade parafuncional.

WILKINSON et al. $^{183}$, em 1992, e EKBERG; NILNER ${ }^{48}$ creditam o sucesso ao alívio de carga na ATM. Sobre esse tema, discutirse-á com maiores detalhes posteriormente.

Além disso, diversas outras teorias foram propostas, como teoria da conscientização do efeito placebo, do efeito psicológico, que também pode estar sozinho ou associado com outros mecanismos ${ }^{35},{ }^{42}$.

Enfim, não se chegou, ainda, a nenhuma conclusão sobre o mecanismo de ação da placa.

Historicamente, o desenho da placa baseou-se nas teorias dos efeitos terapêuticos. Muitos pesquisadores imaginaram que a guia pelo canino fosse uma característica crítica no desenho da placa. A razão para isso foi baseada, inicialmente, por $\mathrm{D}^{\prime} \mathrm{AMICO}^{41}$, que afirmou: "quando os caninos entram em contato, há uma interrupção imediata na tensão dos 
músculos temporal e masseter, reduzindo, assim, a magnitude da força aplicada".

Investigações posteriores ${ }^{2,15,24,18,53,110,120,121,161, ~ 162, ~ 164, ~} 186$, envolvendo avaliação da atividade eletromiográfica dos músculos elevadores da mandíbula durante apertamento, tanto na máxima intercuspidação como nos movimentos excursivos sobre os próprios dentes e sobre a placa, ofereceram suporte para essa idéia.

Alguns trabalhos $2,18,110,121,164,186$ evidenciaram ter havido uma menor redução de atividade eletromiográfica dos músculos temporal e masseter durante o apertamento sobre guias pelo canino, quando comparado com guias por função em grupo. Outros ${ }^{15,36,106,111}$ mostraram resultados semelhantes quando esse apertamento era executado sobre dentes ou sobre guias oclusais artificiais fixadas sobre dente simulando guia $^{6,15}$.

Segundo MAJOR; NEBBE ${ }^{109}$, apesar de os estudos que envolvem a atividade eletromiográfica serem mais favoráveis à guia pelo canino, a atividade eletromiográfica como um instrumento clínico para medir a resposta de um indivíduo ao tratamento não é válido, e deve ser reservada para a pesquisa clínica. Isso porque os aumentos ou reduções nos níveis de atividade eletromiográfica nem sempre são acompanhados por alterações paralelas nos sinais e sintomas de DTM, como mostram RUGH et al ${ }^{150}$.

Além disso, os resultados envolvendo a atividade eletromiográfica são bastante contraditórios e neles podemos encontrar 
tanto redução ${ }^{2}, 15,18,24,53,110,121,161,162,186$ como aumento ${ }^{08,120,190}$ da atividade na mesma amostra envolvendo experimentos diferentes como resultados opostos ${ }^{37,76}$, no mesmo experimento, nos diversos estudos de eletromiografia. Portanto, não devemos utilizar a atividade eletromiográfica como parâmetro na avaliação e diagnóstico dos indivíduos com DTM.

Em alguns estudos ${ }^{102,149,150}$, foi realizada uma comparação com placas não só estabelecendo guia pelo canino, mas também guia só pelo molar incorporado à placa estabilizadora, como $\mathrm{RUGH}^{149,}{ }^{150}$, que verificou não haver diferença nenhuma nos dois estilos de desoclusão efetuados em oito indivíduos com bruxismo e sintomas de DTM associados; e LOUS ${ }^{102}$, que relatou melhora nos sinais e sintomas de DTM em pacientes tratados com uma placa estabilizadora tendo apenas contato posterior na região do segundo molar. Esses resultados, portanto, questionam a suposição comum de que a guia pelo canino seja uma característica crítica do desenho da placa para o tratamento das DTMs.

Alguns estudos ${ }^{23,}$ 116, 158, 159 , entretanto, relatam haver correlação entre os contatos no lado de balanceio e os sinais e sintomas de DTM.

Contrariamente ao pensamento desses autores, muitos outros $^{45,84,88,119}$ acreditam que o contato no lado de balanceio poderia ser um fator positivo para a prevenção das DTMs.

$\mathrm{KAHN}^{84}$ verificou que indivíduos sintomáticos, com e sem deslocamento do disco, tinham significativamente menor quantidade de 
contatos no lado de não-trabalho, se comparados com indivíduos assintomáticos com uma alta prevalência de um ou mais contatos no lado de não-trabalho. Também, MINAGI et al. ${ }^{119}$, em 1990, após uma avaliação em 430 estudantes de Odontologia, verificaram uma correlação altamente significativa entre a ausência de contatos do lado de balanceio e a prevalência aumentada de sons articulares com a idade. Além disso, estudos recentes ${ }^{7}, 81$ indicam que contatos em balanceio podem ser protetores da ATM ipsilateral, corroborando os achados de MINAGI et al. ${ }^{119}$.

De acordo com MINAGI et al. ${ }^{119}$, em 1990, esse conflito poderia ter sido resolvido se houvesse estudos da força no lado de balanceio.

Segundo MARKLUND; WANMAN ${ }^{115}$, muitas opiniões divergentes têm sido advogadas, mas o suporte científico sobre essas questões é muito fraco, sem estudos controlados, com amostras pequenas visando a avaliar o risco ou benefício dos diferentes padrões de contato durante as excursões laterais.

E isso ainda se torna mais difícil se observarmos que não existe, ainda, um sistema de classificação sobre os padrões de contato adotados por todos, devido a enormes variações dos contatos encontrados, por falta de medidas padronizadas e diferentes técnicas para identificar o padrão de contato existente ${ }^{131,189}$. 
As pesquisas têm demonstrado que 47 a $64 \%$ dos dentes naturais dispõem-se numa configuração de função em grupo, enquanto apenas 2 a $17 \%$ dispõem-se numa configuração de guia anterior ${ }^{19}$.

E, finalmente, investigações mais recentes falam da possibilidade da articulação temporomandibular receber cargas sob diferentes padrões da guia adotados sobre a placa durante o movimento excursivo $^{91,97,130,143,153,190}$.

Devido à existência de poucos estudos envolvendo diferentes formas de desenho das placas, em se tratando de guia com relação ao tratamento das desordens temporomandibulares, principalmente em questões ainda obscuras, pergunta-se como a distribuição de cargas na ATM pode ser alterada para atingir com segurança um benefício terapêutico?

\section{Metodologia}

Neste estudo, compararam-se os resultados obtidos de um tratamento em indivíduos com deslocamento do disco com redução, utilizando uma placa estabilizadora com guia modificada, com os resultados de outro grupo de indivíduos utilizando uma placa estabilizadora com guia pelos caninos. Os resultados desses 2 grupos também foram comparados com um terceiro grupo, utilizando uma placa não oclusiva. 
Apesar dos inúmeros sucessos relatados, na literatura ${ }^{5,28,29,}$ $49,58,103,133,138,141,146,177,183$, sobre o uso de placas estabilizadoras com guia pelo canino no tratamento das patologias intra-articulares, investigações recentes $^{91}, 97,130,143,153,190$ falam de carga empregada na articulação temporomandibular pelos diferentes tipos de placa. Inúmeros trabalhos citam que parte da força aplicada sobre os dentes é direcionada para a $\mathrm{ATM}^{11,13,17,50,73,85,87,108,129,169,170,181}$, e que quanto mais anterior for o contato do dente na placa, maior a carga aplicada na ATM. Além do que, outros $^{7}, 81,153$ relatam que a ATM sofre forças de tensão (compressão e distração) durante o apertamento unilateral, e outros ${ }^{7,81,88}$ que, ao estabelecer contatos simultâneos em ambos os lados (trabalho e balanceio), durante os movimentos excursivos (oclusão balanceada), a força direcionada para a ATM do lado de balanceio é bastante reduzida.

Assim, diante desses conceitos apresentados na literatura e devido a ATM de indivíduos com deslocamento do disco com redução terem sua capacidade de proteção reduzida devido ao disco estar fora de sua posição normal, esses indivíduos podem estar, ainda, acometidos de processos patológicos como sinovite, capsulite, etc. E uma vez que uma das funções do disco é proteger e dissipar melhor as forças direcionadas na ATM, propôs-se a investigar o tratamento de indivíduos com deslocamento de disco com redução com uma placa estabilizadora, com guia modificada (balanceada). Isso porque, supõe-se que, ao se estabelecer, também, um ponto de apoio no lado contralateral aos outros dois pontos estabelecidos no lado de trabalho (canino e molar), o indivíduo, ao executar os movimentos 
excursivos, terá uma melhor estabilidade mandibular. Diminuir-se-ia, assim, a ação de alavanca que, possivelmente, as placas estabilizadoras com guia pelo canino teriam (já que as mesmas desocluem todos os dentes posteriores durante os movimentos excursivos). E, conseqüentemente, a força direcionada para as ATMs do lado de balanceio seria diminuída, durante os movimentos excursivos, possibilitando, assim, uma melhor reparação das estruturas afetadas.

Neste projeto, houve uma presença dominante de mulheres: 52 contra 5 homens, de um total de 57 indivíduos com idade média de 29,95 anos, sendo 19 indivíduos selecionados para o grupo com placa balanceada, com idade média de $28,95 \pm 8,63 ; 20$ indivíduos para o grupo com placa com guia, com idade média de 31,35 \pm 13,25 e 18 indivíduos para o grupo placebo, com idade média de 29,56 \pm 10,65. Essa desigualdade na distribuição dos indivíduos deveu-se à desistência de 3 componentes durante a pesquisa, sendo 2 do grupo placebo, devido à não-melhora dos sintomas, e 1 do grupo com guia balanceada, por mudança de endereço, já que o início do projeto começou com 60 indivíduos, igualmente distribuídos pelos 3 grupos. Apesar de o ideal na elaboração de um determinado experimento clínico a amostra ser composta por indivíduos de ambos os sexos, divididos igualmente, neste projeto isso não foi possível porque, normalmente, o número de mulheres com sinais e sintomas de DTM é bem superior em relação aos homens ${ }^{37,39,57,66,122,162 .}$ 
Além do que, a seleção desses indivíduos foi feita em um período de 3 e 4 meses, atendendo a uma média de 180 a 200 pacientes, quando apenas 60 indivíduos tiveram os critérios de inclusão estabelecidos para este projeto, que foi a presença do estalido recíproco, ou seja, estalido na abertura e fechamento; queixa de dor e sensibilidade à palpação na ATM em pelo menos um dos lados, que são sintomas e sinais clínicos característicos de deslocamento de disco com redução.

\section{Processo de seleção}

O processo de seleção dos indivíduos nos três grupos foi cuidadosamente considerado, para evitar, mesmo por sorteio, que algum grupo houvesse só selecionado indivíduos com dores leves ou moderadas, evitando suposições tendenciosas.

Para tornar os resultados mais consistentes, o processo de inclusão nos grupos I, II e III foi realizado de maneira aleatória, de acordo com a severidade dos sinais e sintomas de DTM presente, tomando-se o cuidado de, primeiramente, separar proporcionalmente os indivíduos com dor baseada na análise subjetiva e objetiva da dor, ou seja, primeiramente os indivíduos foram separados em relação à sensibilidade à dor, de acordo com a avaliação da escala de análise visual (EAV) e pela palpação da ATM e músculos da mastigação. Após a separação, os indivíduos foram separados pela severidade dos sintomas em 3 grupos: severa, moderada e fraca. A partir daí, foram distribuídos aleatoriamente para um dos 3 grupos. 
Essa seleção foi feita pelo pesquisador, juntamente com o orientador da pesquisa. Como é impossível não conhecer a que grupo cada componente representa devido ao formato da placa, e devido à dificuldade de se obter a participação de mais um pesquisador, decidiu-se que o próprio pesquisador principal realizasse a avaliação.

\section{Confecção das placas}

Em relação às placas, foi possível discutir alguns aspectos importantes referentes a sua confecção. Existem várias técnicas no registro da relação maxilo-mandibular. Entretanto, devido ao fato de os indivíduos possuírem deslocamento do disco com redução, a montagem de seus modelos para a confecção das placas foi realizada pela técnica de ponta do mento, suavemente, de maneira a não forçar os côndilos contra a ATM, pelo risco de se aplicar forças indesejáveis no aspecto posterior do disco e nos tecidos retrodiscais, já que esses tecidos são altamente vascularizados e bem supridos por fibras nervosas sensoriais. Portanto, esses tecidos não são estruturados para aceitar forças, correndo o risco de causar danos ou início de dor durante a manipulação.

$\mathrm{Na}$ confecção das guias pelo canino sobre as placas, optouse por fazê-las com um menor trespasse vertical, apenas para permitir a desoclusão total dos dentes posteriores, de maneira que não fosse possível uma elevação maior nos níveis de atividade muscular necessárias para o movimento da mandíbula de acordo com Katona ${ }^{85}$. 


\section{Avaliação}

Muitos estudos ${ }^{43,49}$ que avaliaram o tratamento das DTMs empregaram medidas subjetivas simples para avaliação dos resultados. Contudo, resultados baseados somente em análises subjetivas são suceptíveis à interpretações equivocadas. Portanto, decidiu-se realizar, neste trabalho, uma avaliação mais ampla, envolvendo uma avaliação subjetiva, em que foi utilizada uma escala de análise visual (EAV), além de uma avaliação objetiva, através da análise dos movimentos da mandíbula, dos ruídos articulares, palpação da ATM e dos músculos elevadores da mandíbula.

Apesar da variabilidade entre os diversos trabalhos em relação ao tempo, ao método e à metodologia usada na palpação da ATM e dos músculos, para este estudo utilizou-se uma palpação digital exercendo uma pressão de $1000 \mathrm{~g}$ para ATM e $1500 \mathrm{~g}$ para os músculos, exercendo uma pressão firme, porém de maneira suave e constante de acordo com SANTOS $^{152}$ e MIRANDA ${ }^{122}$.

A razão de ser incluída, também, a palpação dos músculos temporal e masseter é que pacientes que apresentam patologias intraarticulares podem apresentar sensibilidade muscular, (contração protetora, mialgia, etc.), ao redor da ATM. Isso acontece devido a uma reação do organismo, como forma de proteger a ATM e, portanto, a avaliação da sensibilidade desses músculos pela palpação seria uma maneira de avaliar o progresso do tratamento realizado sobre a desordem intra-articular. 


\section{EAV (Escala de Análise Visual)}

Neste projeto, as médias de EAV iniciais, nos três grupos estudados, foram semelhantes entre si, apresentando uma média de $63,2 \mathrm{~mm}$ para o grupo com placa balanceada; $68,0 \mathrm{~mm}$ para o grupo com placa com guia e $62,7 \mathrm{~mm}$ para o grupo controle, evitando assim, tendência de preferência para determinado grupo.

Os resultados mostraram que, independentemente do grupo, os valores médios da EAV diminuíram. No grupo I (placa balanceada), a EAV inicial média foi de $63,2 \mathrm{~mm}$ e a final de $10,5 \mathrm{~mm}$. No grupo II, a EAV foi de $68,0 \mathrm{~mm}$ e o valor final de $9,5 \mathrm{~mm}$; no grupo placebo, a EAV inicial foi de $62,7 \mathrm{~mm}$ e a final, de $27,2 \mathrm{~mm}$, de acordo com a tabela 3 . Como se pode notar, apesar de ocorrer melhora no relato de dor, nos três grupos avaliados, desde a avaliação inicial até a final, conforme Figura 5, houve diferença estatisticamente significante na alteração total da EAV apenas entre os grupos II (placa com guia) e grupo III (placebo). Não houve diferença significante entre os grupos I (balanceada) e II (placa com guia), nem entre os grupos I e III, conforme Tabela 7.

Como o relato de desconforto à dor pelo paciente é importante, já que se procurou, principalmente por uma melhora na qualidade de vida dos pacientes do que propriamente a regressão total da sensibilidade dos músculos e da ATM, que percebe-se, pelas Tabelas 4 e 6, que apesar de não haver diferença entre os grupos I (balanceada) e III 
(placebo), a alteração do relato da dor dos pacientes do grupo I (balanceada) foi mais significativa, isto porque dos 19 indivíduos do grupo 1 (balanceada) que relataram algum desconforto à dor, 14 marcaram "0" (ausência de dor) sobre a EAV, enquanto no grupo 3 dos 18 indivíduos, apenas 5 marcaram "0". Percebe-se, também, pela tabela 4, que logo na primeira reavaliação (7 dias) essa alteração foi bastante significativa, na segunda reavaliação (15 dias), essa alteração permaneceu a mesma; após 1 mês ( $3^{a}$ reavaliação) houve, novamente, alteração significativa, permanecendo assim nas $4^{\mathrm{a}}$ e $5^{\mathrm{a}}$ avaliações restantes (Tabela 4).

Já no grupo III (placebo), na $1^{\text {a }}$ reavaliação (7 dias) não houve alteração significativa, isso ocorrendo somente na $2^{\mathrm{a}}$ reavaliação; na $3^{a}$ reavaliação houve, novamente, alteração significativa; na $4^{a}$ e também na $5^{a}$ (Tabela 6). Observa-se que, enquanto no grupo I (balanceada) essa alteração já foi significativa na $1^{a}$ reavaliação, no grupo III essa alteração só ocorreu na $2^{\mathrm{a}}$ reavaliação (15 dias), tendo apenas uma redução no percentual da dor conforme os meses iam passando. Enquanto no grupo I, essas dores já permaneceram reduzidas a partir da $3^{a}$ reavaliação (30 dias).

Diante disso, pode-se perceber que, apesar de não ser estatisticamente significante, as dores relatadas pelos pacientes do Grupo I (balanceada) diminuíram em menor tempo que as do grupo III.

Comparando esses resultados com outros trabalhos, esse estudo demonstrou um melhor resultado no tratamento com placa de estabilização com guia pelo canino do que o grupo tratado com a placa não 
oclusiva, indo ao encontro dos resultados obtidos por EKBERG ${ }^{49}$ e colaboradores, GREEN e LASKIN ${ }^{67}$. Esses resultados contrastam com aqueles de DAO e $\operatorname{colegas}^{43}$ e RUBINOFF ${ }^{146}$, e colaboradores que não encontraram diferença entre os grupos tratados com placa de estabilização e controle utilizando a placa não oclusiva.

A porcentagem de indivíduos que responderam ao

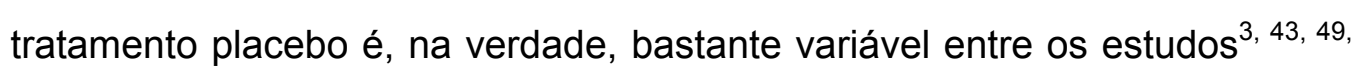
67, 90, 96, 103, 104, 122, 146 . Quando os indivíduos não estão cientes de que podem estar apresentando uma resposta placebo, a taxa de sucesso de tratamento é mais alta que um terço. Por exemplo, um estudo relatou que $64 \%$ dos indivíduos submetidos a um falso ajuste oclusal como tratamento para dor miofascial, tiveram boa melhora e remissão dos sintomas ${ }^{60}$.

Alguns autores ${ }^{14,16,67}$ acreditam que a expectativa cognitiva dos indivíduos, ou a crença de que o tratamento será efetivo, tem um papel importante na resposta placebo.

Especificamente, os indivíduos em um grupo controle sem tratamento, na lista de espera, não têm expectativa de melhora, de tal forma que algumas alterações observadas são o simples efeito do tratamento sobre o nível do sintoma ${ }^{90}$. Por outro lado, os indivíduos com um estudo com controle placebo (placa não oclusiva), especialmente quando não são informados de que estarão recebendo um placebo, têm altas expectativas de melhora que induzem a resultado muito positivo. 
Em nossos estudos, os indivíduos, apesar de receberem uma placa não-oclusiva, foram orientados da mesma maneira que os indivíduos do grupo I e do grupo II, ou seja, receberam instruções de que estariam usando uma placa, e que a mesma teria um efeito benéfico sobre os sinais e sintomas da DTM.

Não foi possível comparar o grupo com placa balanceada com outros estudos pela inexistência de resultados com esse tipo de placa modificada.

Após a conclusão dos resultados do tratamento realizado, decidimos trocar todas as placas do grupo I pelas placas do grupo II (com guia). O mesmo foi realizado nos indivíduos do grupo III e, após um mês de uso com as placas novas (com guia pelo canino) foi feita outra avaliação. Dos 18 indivíduos do grupo III (placebo), 13 relataram que ainda continuaram a sentir dor e apenas 5 disseram que as dores melhoram por completo. Portanto, após a colocação da placa pelo canino, a grande maioria desses indivíduos teve as suas dores totalmente reduzidas. Foi perguntado a eles como estavam se sentindo com a nova placa e as respostas foram inúmeras:

"a mudança foi radical, engraçado"; "sentia um pouco tenso no início, mas depois as dores melhoraram"; "depois da colocação desta placa nova não senti mais dor de cabeça, a mordida está melhor e estou me sentindo bem"; "foi um pouco difícil para acostumar mas as dores sumiram". 
Já no grupo I (balanceada), cujos indivíduos receberam a placa com guia pelo canino, não houve alterações com os resultados.

Diante dessas considerações, e apesar dos resultados estatísticos afirmando que não houve diferença entre o grupo I (balanceada) e o grupo III (placebo), podemos afirmar que as placas, tanto com guia quanto a balanceada, obtiveram melhores resultados que a placa não oclusiva (placebo).

\section{Movimento mandibular}

Com relação ao grau de abertura bucal, cuja média inicial foi 47,06 $\mathrm{mm}$ e final 47,99 $\mathrm{mm}$, não houve diferença estatisticamente significante entre os três grupos envolvidos. A média inicial da abertura máxima para o grupo com placa balanceada foi de $46 \mathrm{~mm}$ e final $47,3 \mathrm{~mm}$; a do grupo II (placa com guia), 45,9 mm e final 47,25 mm; e no grupo III (placebo), a inicial foi $49,28 \mathrm{~mm}$ e final $49,44 \mathrm{~mm}$, conforme Tabela 8 . Diante desses resultados, apesar de não serem estatisticamente significantes, percebe-se uma melhora na abertura nos grupos I e II (Figura 6). Houve uma melhora discreta nesses 2 grupos, apesar da limitação da abertura não ter sido apresentada como queixa em relação ao desconforto, já que todos os indivíduos da amostra tiveram uma abertura compatível com a normalidade prevista entre $40 \mathrm{~mm}$ e $55 \mathrm{~mm}^{122}$. 
Os movimentos excursivos da mandíbula (lateralidade direita e esquerda, protrusão) também foram analisados nos diferentes grupos.

Verificou-se que, para a lateralidade direita, houve diferença estatisticamente significante entre os grupos I (placa balanceada) e o grupo III (placebo), neste último ocorrendo maior variação, conforme exposto na Tabela 9 e 10. Em relação aos outros grupos, não houve diferença estatisticamente significante. Essa diferença estatística para o grupo III (placebo) deveu-se, possivelmente, como relatado anteriormente, ao fato de a grande maioria dos indivíduos selecionados para esse experimento não ter dificuldade de movimentação da mandíbula.

Com relação aos movimentos de lateralidade esquerda e protrusiva, também não houve diferença estatisticamente significante entre os três grupos, tendo-se encontrado uma média inicial de 9,48 mm para a lateralidade esquerda e de 9,86 mm para a final, conforme Tabela 11; e para o movimento protrusivo, uma média inicial de $6,81 \mathrm{~mm}$ e final de $7,35 \mathrm{~mm}$, conforme Tabela 12.

\section{Dores Articulares}

Existem várias causas diferentes de dor na ATM, mas os fatores comuns incluem trauma de carga adversa e repetitiva, podendo levar a alterações articulares degenerativas ou à inflamação e dor. A utilização da placa estabilizadora para reduzir a carga e dor subseqüente na ATM é 
bastante relatada na literatura ${ }^{5,28,29,49,58,103,133,138,141,146,177,183}$, apesar de existir outro tipo de placa (reposicionamento anterior) para o tratamento dessas desordens. Um sintoma comum dessas patologias intra-articular é a dor articular que piora pelo movimento e função articular.

Por muitos anos, pensou-se que a ATM não recebia carga $^{147}$. Porém, muitos trabalhos em animais e modelos experimentais demonstraram que a ATM é submetida a cargas durante a função 6, 12, 13, 17, 31 , $51,55,72,80,87,85,87,88,91,97,108,119,124,129,130,136,143,153,169,170,176,181,190$.

Várias técnicas, então, foram propostas na avaliação e na

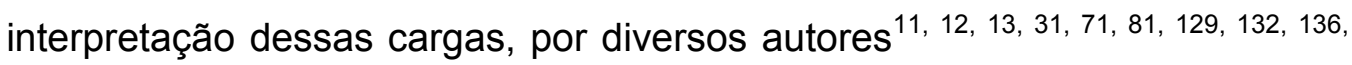
$153,170,174,176,181$.

Alguns $^{132,170,174,181}$ utilizaram o sistema de alavanca em que, considerando a articulação temporomandibular como o fulcro, a potência, os músculos e a resistência à desoclusão proporcionada pelo canino, pode-se prever como as cargas serão distribuídas entre a ATM e os dentes, baseando-se somente na localização dos contatos, ou seja, à medida que o braço da alavanca (que vai desde a ATM até o ponto de contato dentário) é aumentado, a força aplicada aos dentes é reduzida. Assim, as forças estabelecidas sobre o canino durante os movimentos excursivos serão diminuídas. O mesmo não ocorre com o contato executado nos dentes molares, pois como se aproximam dos músculos potentes (elevadores da mandíbula, temporal e masseter) fazendo com que seu braço de alavanca fique menor e, conseqüentemente, uma maior carga 
seja direcionada para eles. Isso foi verificado através de trabalhos simulando uma alavanca e apoiados por outros utilizando transdutores para medição das forças, onde verificou-se que a magnitude da força da mordida variou por um fator de nove entre os dentes posteriores $(202,5 \mathrm{lb})$ e anteriores $(22,5 \mathrm{lb})^{114}$.

De acordo com o sistema de alavanca classe III, da mesma maneira que ocorre uma diminuição de forças sobre os dentes, à medida que o ponto de contato é movido anteriormente, há um aumento de forças

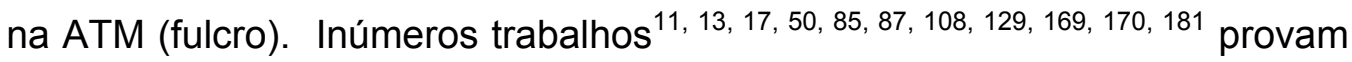
essa relação como o de SMITH, MCLACHLAN e MCCALL ${ }^{169}$, os quais verificaram que a ATM recebeu uma carga de $60 \%$ da força de mordida quando era executada pressão sobre os incisivos. Quando essa pressão era feita sobre os molares, a carga caía para $5 \%$ e diminuía mais ainda quando essas forças de mordida eram dirigidas verticalmente para 0 segundo molar.

Outros $^{7}, 81,153$, basearam-se nos movimentos condilares induzidos por forças de mordida aplicadas sobre os dentes, que produziam forças compressivas ou distratoras na articulação temporomandibular.

Diversos outros trabalhos mediram a força da ATM, alguns utilizando modelos matemáticos ${ }^{11,12,13,50,51,72,87,108,143,169}$, outros modelos com elemento finito ${ }^{31,71,136}$, outros com computadores de última geração ${ }^{88,}$ 129, 176 etc. 
Devido à localização e à pequena área da ATM, poucos trabalhos foram feitos em relação à mensuração direta das forças

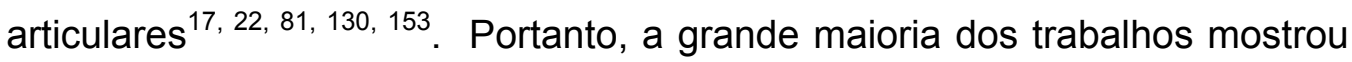
que: a) as articulações temporomandibulares recebem cargas. b) o lado de balanceio recebe maiores cargas do que as do lado de trabalho, quando submetidas às forças unilaterais; c) à medida que os contatos são localizados mais posteriormente, as forças oclusais estabelecidas sobre os dentes ficam maiores, enquanto a força na articulação fica menor.

Há muita confusão sobre a terminologia que descreve as cargas na articulação temporomandibular e sua distinção nem sempre foi claramente definida na literatura odontológica. Isso se deve ao fato de que, ao considerar uma força atuando sobre o côndilo em direção à eminência articular, considerou-se que a ATM estava sob carga. Então, está implícito um conceito nessa afirmativa de que as forças que tendem a movimentar o côndilo em direção contrária à eminência articular "eliminam a carga" da articulação. E isso não é verdade. SMITH ${ }^{169}$ sugere que a carga na ATM seja considerada uma força que age sobre o côndilo, levando a movimentos lineares. Assim uma carga condilar teria as propriedades usuais de uma força, magnitude, direção e ponto de aplicação. Portanto, se existir uma propensão para que o côndilo seja submetido a um movimento linear, ele deve ser considerado sob carga.

Assim, as forças que tendem a movimentar o côndilo em direção à eminência articular serão denominadas "cargas compressivas", e 
as forças que tendem a movimentar o côndilo em direção contrária à eminência articular serão chamadas "cargas distratoras".

Tem sido sugerido que a sobrecarga na ATM pode causar deslocamento do disco ${ }^{42,91}$. Isso pode ter sido baseado na crença de que o aumento da dimensão vertical, devido à espessura da placa, seria acompanhado de um aumento no espaço da articulação e uma diminuição nas forças de carga aplicada sobre as superfícies articulares da ATM.

Ainda existem muitas suposições sobre esse assunto, principalmente diante dos resultados conflitantes e técnicas diferentes nos diversos trabalhos.

Como SANTOS JUNIOR ${ }^{153}$, utilizando um modelo mecânico em que verificou que a placa de estabilização, com o aumento mínimo da dimensão vertical produziu a menor quantidade de força articular comparativamente à placa de reposicionamento anterior. Já ITO ${ }^{81}$ avaliou as forças articulares analisando os movimentos condilares mínimos induzidos por tarefas de apertamento, a partir de pontos de movimentos mandibulares medido por um sistema replicador, e concluiu que não foi induzido desvio condilar significativo pelo apertamento, tanto na placa estabilizadora como na placa de reposicionamento. Além disso, eles supuseram que os efeitos descompressivos foram induzidos pela utilização dos aparelhos oclusais. Se formos considerar a tensão obtida na ATM, apesar de técnicas diferentes, poderemos concluir que os dois trabalhos obtiveram resultados opostos. 
Outro método de avaliação da carga articular foi a medição de pressão intra-articular nas faces posteriores da eminência articular, onde o autor relata que o aparelho interoclusal reduziu significativamente a pressão do fluido intra-articular durante o apertamento ${ }^{130}$. Apesar dos resultados obtidos nesse trabalho serem considerados um achado importante sobre as pressões de fluido do compartimento articular superior, vários autores ${ }^{59,91}$ consideram que tal informação não pode ser diretamente correlacionada para supor alterações na carga sobre a articulação temporomandibular.

Já ISRAEL ${ }^{80}$ verificou que as forças compressivas atuando sobre os tecidos articulares tenham o espaço articular, eventualmente, diminuído. KUBOKI ${ }^{91}$ encontrou resultados opostos em que, através de imagens, verificou que no fechamento mandibular máximo, sobre a placa de estabilização, o espaço articular mínimo foi equivalente àquele visto em máxima intercuspidação, enquanto nas placas de reposicionamento anterior esse espaço foi bem menor. Portanto, os achados de $\mathrm{KUBOKI}^{91}$ e ISRAEL ${ }^{80}$ contradizem a crença de que placa aumenta o espaço articular.

As alterações na transmissão de cargas, após o deslocamento do disco, parecem ocorrer devido a uma área de contato reduzida entre o côndilo, disco e eminência articular. Entretanto, trabalhos ${ }^{166}$ mostram que isso não interfere na diminuição dos sinais e sintomas de pacientes com DTM. Acredita-se que isso se deve à capacidade da adaptação dos tecidos da $\mathrm{ATM}^{19,54,105,117,124,126,167,168 .}$ 
É de se concluir que, apesar das discussões antigas, presentes e, possivelmente, futuras de força sobre a articulação temporomandibular, a mesma recebe uma parte das forças geradas, tanto na máxima intercuspidação como nos movimentos excursivos com placa ${ }^{7,81}$, 153 ou sem placa ${ }^{11,12,13,88,129,143,176}$, apesar de posições contrárias sobre o assunto $^{147}$.

Neste trabalho, apesar de a medição de força na ATM não ser nosso objetivo, verificamos que, clinicamente, o padrão de contato dentário sobre a placa estabilizadora não interferiu nesse fator clínico, já que não houve diferença estatisticamente significante entre os três grupos avaliados, tanto sob o aspecto lateral como no aspecto posterior de ambas as ATMs, embora variações significativas tenham sido detectadas na análise intragrupo, com o passar do tempo, em ambos os itens avaliados.

Assim, no aspecto lateral da ATM direita, verificou-se a presença de diferença significante entre os valores de dor à palpação, ao longo das avaliações, para todos os grupos. Para o grupo I (placa balanceada), essa diferença ocorreu logo na primeira reavaliação (7 dias), conforme Tabela 14, havendo uma redução significativa na dor à palpação. Entretanto, a partir daí, as alterações não foram mais significativas. Já no grupo II (placa com guia), essa redução significativa ocorreu na primeira reavaliação (7 dias) e segunda reavaliação (Tabela 15), permanecendo sem alterações a partir daí; e no terceiro grupo (placebo), a mesma redução 
significativa ocorreu, também, na primeira reavaliação, permanecendo sem alterações (Tabela 16).

Apesar de não podermos afirmar, com certeza já que os resultados entre os 3 grupos foram não estatisticamente significantes, podemos perceber, de acordo com o gráfico da Figura 7, que no decorrer do tempo, o grupo com placa balanceada apresentou os melhores resultados, seguidos do grupo com placa com guia e por último, o grupo controle, onde inclusive houve um aumento dessa sensibilidade. Isso vem comprovar o efeito de uma maior estabilidade da mandíbula (oferecida pelos três pontos de contato obtidos na placa balanceada, durante os movimentos excursivos), na distribuição de forças para a ATM, se levarmos em conta a diminuição da sensibilidade muscular e aspecto lateral da ATM.

Já na palpação, no aspecto lateral da ATM esquerda, as reduções foram significativas, mas um pouco diferentes. Para o grupo I (placa balanceada), houve redução significativa da dor à palpação logo na primeira reavaliação seguida de nova redução significativa na terceira reavaliação (1 mês) (Tabela 17). Já no grupo II (placa com guia) e grupo III (placebo), essa redução ocorreu na primeira reavaliação (7 dias) permanecendo sem alterações significativas nas reavaliações restantes, conforme demonstrado nas Tabelas 18 e 19, respectivamente.

Por esses resultados percebe-se, pelo gráfico da figura 8 , a relação de proteção das forças nas ATMs obtida pelo equilíbrio da mandíbula efetuado durante os movimentos excursivos nos três lados da 
placa no Grupo I (balanceada), já que houve uma maior redução de sensibilidade no aspecto lateral da ATM esquerda por esse grupo, quando comparado aos outros 2 grupos, percebendo-se, também, um aumento da sensibilidade na última reavaliação (6 meses), demonstrado pelo grupo III (placebo).

Em relação ao aspecto posterior da ATM direita, enquanto o grupo I (placa balanceada) demonstrou que houve redução significativa da dor à palpação logo na primeira reavaliação (7 dias), seguida de nova redução significativa na segunda reavaliação (15 dias) (Tabela 20), permanecendo sem alterações a partir de outras reavaliações, no grupo II (placa com guia) essa redução ocorreu na primeira reavaliação (7 dias), segunda reavaliação (15 dias) e última (6 meses) - Tabela 24. Já no grupo III (placebo), a redução ocorreu na primeira reavaliação (7 dias), permanecendo inalterada nas outras reavaliações (Tabela 22).

Percebe-se, mais uma vez, pela figura 9, que os melhores resultados foram obtidos nos grupos I e II, placa balanceada e placa com guia, respectivamente. Se levarmos em conta o fator proteção para as ATMs, nota-se que ocorreu, também, diminuição da sensibilidade no aspecto posterior da ATM direita no grupo III. Com relação ao aspecto posterior da ATM esquerda, enquanto no grupo I (balanceada) a redução significativa ocorreu apenas na terceira reavaliação (1 mês), permanecendo inalterada nas outras reavaliações, conforme tabela 23 , no grupo II ocorreu apenas na 
quarta reavaliação (3 meses) e última reavaliação (6 meses), conforme Tabela 24.

Já no grupo III (placebo), redução significativa ocorreu na primeira reavaliação (7 dias), não havendo mais alterações significativas a partir daí. (Tabela 25).

Percebe-se, agora (Figura 10), que com relação à diminuição da dor pela palpação, no aspecto posterior da ATM esquerda, o grupo que apresentou melhores resultados foi o grupo II (placa com guia), e o pior resultado, obedecendo à mesma tendência observada no aspecto lateral direito e esquerda e aspecto posterior da ATM direita, foi o do grupo III.

Portanto, podemos verificar que a diminuição da sensibilidade verificada pela palpação, no aspecto lateral e posterior de ambas as ATMs, ocorreu nos três grupos, mas o pior resultado foi verificado no grupo III (placebo), e que o grupo II (placa com guia) obteve o melhor resultado apenas no aspecto posterior da ATM esquerda, enquanto que o grupo I (balanceada) obteve os melhores resultados no aspecto lateral das ATMs esquerda e direita, e no aspecto posterior quando a avaliação intragrupos foi considerada. 


\section{Ruído articular}

Um dos sinais clínicos mais freqüentes nas patologias intraarticulares é a presença de um estalido articular que é uma manifestação, principalmente durante a fase inicial da abertura bucal, da perda temporária do disco. Esse fenômeno, geralmente, é conhecido como deslocamento do disco com redução.

Para MAJOR; NEBLE ${ }^{109}$, para que o disco seja deslocado, deve haver uma perda da capacidade normal de auto-assentamento do disco, bem como dano nos ligamentos discais.

Apesar da utilização desses critérios clínicos para o estabelecimento do diagnóstico como deslocamento do disco com redução, para se ter a certeza de que existe, realmente, um deslocamento do disco, teríamos que lançar mão de técnicas de imagem de alta precisão na localização do disco, como a ressonância magnética. Como associamos outros critérios para o estabelecimento de tal condição e como o custo de imagens de ressonância é muito alto, desconsideramos esse critério de imagem.

Como foi considerado um dos fatores essenciais para a inclusão na amostra de nosso projeto, todos os indivíduos apresentaram sinal de estalido em pelo menos um dos lados, tanto na abertura, como no fechamento. Sendo considerado, para muitos autores ${ }^{35,42,95,96,132}$ como o sintoma de desordens temporomandibulares mais resistente ao tratamento, tal fato também ocorreu no presente trabalho. 
Não foi verificada a associação entre a presença e ausência de ruídos articulares e os diferentes grupos, em cada avaliação. Percebese, pela Tabela 13, que dos 19 do grupo I (placa balanceada), apenas em três houve melhora do estalido; do grupo II (placa com guia), apenas 6 melhoraram e do grupo III (placebo), apenas 3. Portanto, houve apenas uma discreta redução no número de indivíduos com ruídos articulares em todos os grupos, sendo um pouco mais nítido no grupo II (placa com guia).

No presente trabalho, apenas $21,05 \%$ dos indivíduos apresentaram melhora do estalido. Já SHEIKHOLESLAM; HOLMGREN; RIISE $^{162}$. reduziram os estalidos de $55 \%$ para $42 \%$ em $3-6$ meses de utilização de placa, mas os sintomas retornaram em 1-4 semanas após a interrupção do tratamento em $80 \%$ dos casos, enquanto TSUGA et al. ${ }^{177}$ demonstraram desaparecimento completo dos ruídos em $37 \%$ dos indivíduos e redução gradual em $78 \%$, após 13 semanas de terapia com placa estabilizadora.

GREENE; LASKIN ${ }^{67} ;$ SATO $^{154}$ também relataram que o ruído é o sintoma mais resistente ao tratamento em seus estudos.

GOHARIAN; NEFF ${ }^{58}$ relataram, especificamente, o efeito das placas e ajuste oclusal sobre o ruído em 5 indivíduos. Eles encontraram que em 3, dos 5 indivíduos, o ruído não teve alteração, enquanto os outros 2 relataram uma melhora.

Esses estudos parecem concordar que o ruído é um sintoma persistente. Parece, porque outros trabalhos mostraram que houve uma 
melhora nos ruídos articulares, como LOUS ${ }^{102}$, que relatou uma melhora de $75 \%$; TSUGA et al. ${ }^{177}$, que mostrou que $78 \%$ dos indivíduos tiveram alguma melhora no padrão do ruído da ATM.

Apesar da maioria dos trabalhos ${ }^{35,}$ 42, 95, 96, 103, 104, 132 relatarem o ruído articular como persistente ao tratamento, ele não é considerado um fator importante ao tratamento porque inúmeros trabalhos mostram que o sucesso clínico não é associado à posição ideal do disco, pois técnicas de imagens mostraram o disco deslocado e os indivíduos não apresentaram mais dor e nem ruído articular. Possivelmente, houve uma adaptação dos tecidos articulares da $\operatorname{ATM}^{117,124,126,167 .}$

\section{Dores musculares}

Apesar de não ser o objetivo principal desta pesquisa, efeitos das placas nos músculos da mastigação, também são analisados.

A dor nos músculos da mastigação é uma queixa comum em indivíduos com DTM. A patofisiologia da dor original dos músculos esqueléticos não é clara e, dessa forma, o mecanismo de ação da placa também não é bem compreendido. Uma das explicações para a redução dos sintomas musculares com o uso das placas é a diminuição da hiperatividade muscular.

LOBBEZOO et al. ${ }^{99}(1993)$ e VISSER et al. ${ }^{180}$ relataram uma diminuição na atividade do músculo temporal depois da inserção de uma 
placa de estabilização, assim como HUMSI et al. ${ }^{77}$ (1989). Vários outros autores relataram que, com a inserção de uma placa estabilizadora, houve uma diminuição na atividade dos músculos.

BELSER; HANNAN ${ }^{15}$ (1985) e BABA et al. ${ }^{6}$ (1996), por exemplo, relataram que esforços de apertamento lateral no canino natural causaram atividade unilateral nos músculos temporal anterior e posterior com clara dominância do lado de trabalho, e que a introdução de um contato no lado de balanceio mudou esses padrões de atividade unilateral para bilateral. Apesar de não existirem dados objetivos apresentados, eles sugeriram que essa atividade mastigatória alterada do músculo poderia mudar a natureza das cargas na articulação.

De acordo com CRISTENSEN ${ }^{33}$, a força do músculo esquelético depende do comprimento das fibras musculares, e quando esse comprimento, no qual a fibra é estimulada está acima de $150 \%$ ou abaixo de $60 \%$ do seu comprimento original, não é gerada força contráctil. Assim, de acordo com CANAY et al. $^{26}$, nas posições de topo à topo, as fibras musculares podem ser esticadas à limites que aproximam-se desses extremos, e, dessa forma, colaboram com a atividade eletromiográfica (EMG) reduzida.

Neste trabalho, após o uso das placas, observou-se que houve uma redução da sensibilidade dos músculos, (apesar de não se ter encontrado diferença estatisticamente significante com essa variável nos 3 grupos analisados), nas diversas porções avaliadas, com exceção da porção 
anterior do músculo temporal esquerdo e do corpo do músculo masseter esquerdo. Neste, a diferença observada foi entre os grupos I (placa balanceada) e grupo III (placebo), sendo que o grupo I apresentou uma maior redução da dor do que o grupo III. Observa-se que a variação à dor pela palpação, após as 6 avaliações realizadas, foi de 1,47\% para o grupo I e 0,28\% para o grupo III, conforme a Tabela 28. Já na porção anterior do músculo temporal esquerdo, a diferença estatisticamente significante foi observada entre os grupos II (placa com guia) e grupo III (placebo), sendo que o grupo II apresentou uma maior redução comparativamente ao grupo III. Observa-se que a variação à dor pela palpação, após as 6 avaliações realizadas, foi de $1,20 \%$ para o grupo II e $0,00 \%$ para o grupo III, conforme a Tabela 27.

\section{Relato do paciente}

Para verificar o relato do paciente, em relação à mudança de mordida, ao estalido e ao conforto, com a placa foi questionado se, após o tratamento concluído, esses três itens acima referidos permaneceram sem mudança, alteraram para melhor ou alteraram para pior.

Com relação ao ruído articular, notou-se que, ao longo das avaliações, o valor percentual de respostas "manteve-se" diminuía, ao passo que o valor das respostas "alterou para melhor" aumentou para os grupos I (placa balanceada) e II (placa com guia). Para o grupo III, parece haver uma constância nos valores percentuais. Verificou-se que houve uma diferença 
bastante significativa na $3^{a}$ avaliação (1 mês) para o grupo I (placa balanceada) e a resposta "alterou para melhor", em que $73,7 \%$ responderam que a placa havia reduzido os ruídos articulares; para o grupo III (placebo), na resposta "manteve-se", 66,7\% responderam que não houve alteração dos ruídos articulares com o uso da placa placebo. Na $5^{a}$ avaliação (6 meses), novamente houve uma diferença significativa para o grupo I (placa balanceada) e a resposta "alterou para melhor", com 79\%; para o grupo II (placa com guia), e a resposta "alterou para melhor", com 65\%; e para o grupo III (placebo) a resposta "manteve-se", com 66,7\%, conforme demonstrado na Tabela 29.

Com esses dados, podemos verificar que o grupo I (placa balanceada) e o grupo II (placa com guia) demonstraram uma maior melhora em relação à queixa do ruído articular comparativamente ao grupo III (placebo).

Com relação às respostas da mudança de mordida, apesar de não ter existido qualquer associação entre os grupos e as respostas, observou-se, pela Tabela 30, que nos grupos I (placa balanceada) e II (placa com guia) parece haver um aumento nos valores de respostas "alterou para melhor". Para o grupo III (placebo), os valores parecem não se alterar ao longo das avaliações. Isso vem demonstrar o efeito que uma placa estabilizadora tem no tratamento dos indivíduos devido, talvez, a alguma mudança ocorrida na oclusão, e/ou nos músculos e/ou no direcionamento das cargas para a ATM, já que no grupo III (placebo), os dentes se 
intercuspidaram não havendo interposição de nenhum material que atrapalhasse a oclusão dos dentes.

Com relação ao conforto com a placa, observa-se que houve um aumento acentuado nas respostas "alterou para melhor", sendo mais evidente para o grupo II (placa com guia), seguido pelo grupo I (placa balanceada). Nota-se que o grupo III (placebo) obteve o pior índice no item "alterou para melhor". Observa-se pela Tabela 31 que houve diferença estatisticamente significante apenas em 3 momentos: na $1^{a}, 2^{a}$ e $3^{a}$ avaliações, em relação ao item "alterou para melhor" nos grupos I (placa balanceada) e II (placa com guia). Isso vem a comprovar, mais uma vez, os baixos índices de resposta favorável ao tratamento obtido com as placas não oclusivas.

Após um mês da troca efetuada nos indivíduos do grupo III (placa balanceada) pela placa estabilizadora com guia pelo canino, a grande maioria dos indivíduos disse que o conforto com a placa foi bem melhor. $\mathrm{O}$ mesmo não ocorreu com os indivíduos do grupo I, cujas placas também foram alteradas pela placa com guia pelo canino, que disseram que o conforto continuou o mesmo.

\section{Padrão de guia mandibular}

A experiência clínica e alguns estudos 5 , 8, 28, 29, 32, 43, 44, 48, 49, $58,66,67,92,96,113,133,146,154,177,178,183,185,191$ ofereceram evidência de que a 
placa estabilizadora com guia pelo canino é efetiva na redução dos sinais e sintomas de DTM. De preocupação, entretanto, é a suposição de que os efeitos terapêuticos dependam da guia pelo canino construída sobre a placa. Isso não foi demonstrado experimentalmente em uma população clínica, como LOUS ${ }^{102}$ que relatou alívio no estalido da articulação e outros sintomas utilizando uma placa com pivot que tem contato apenas na região do segundo molar. O mesmo ocorreu com RUGH et al. ${ }^{150}$, que usou placas estabilizadoras com guia pelo canino e pelo molar. Dessa forma, há razão para se questionar a necessidade da guia pelo canino com um aspecto crítico do desenho da placa. A suposição clínica comum de que a placa diminuía os sinais e sintomas através da guia pelo canino, somente, claramente não é apoiada. Pelos trabalhos de RUGH et al. ${ }^{150}$, é provável que algo além da guia pelo canino seja responsável pelo efeito clínico positivo.

Os resultados deste trabalho corroboram os de LOUS $^{102}$ e RUGH et al. ${ }^{150}$ no alívio dos sintomas de indivíduos com DTM, só que em vez das placas com guia (por canino e molar) usadas por $\mathrm{RUGH}^{150}$, e de placa com pivot, nós utilizamos placas com guia pelo canino e guia balanceada.

Além do que, se realmente a guia influencia na alteração dos sinais e sintomas das DTM, aqueles pacientes que possuíssem uma guia pelo canino, provavelmente, estariam menos sujeitos a ter problemas de 
DTM e os trabalhos mostraram que essa relação não existe $25,35,145,155,175$, 189

Embora haja um consenso de que o padrão da guia possa alterar a atividade muscular, não existe evidência do impacto desses esquemas oclusais tanto no sucesso ou falha de um tratamento restaurador, como na prevenção das DTMs. BUTLER et al. $^{25}$, não encontraram diferenças com relação à movimentação mandibular, prevalência de som da ATM ou sensibilidade à palpação nos músculos mastigatórios, quando os padrões de guia lateral foram comparados.

Da mesma maneira, ROBERT et al $^{145}$. não encontraram diferenças com relação ao padrão de guia, com disco deslocado e pacientes sintomáticos com disco normal. Esses estudos sugerem que a presença de sinais e sintomas não podem ser evitados por ambos os esquemas oclusais.

Baseado nesses fatos e nos resultados obtidos, pode-se concluir que a presença de guia de desoclusão efetiva durante os movimentos mandibulares não, necessariamente, levam à redução de dor mais efetiva.

Considerando-se a maior facilidade de obtenção de placas com guias, sugere-se que a mesma continue sendo uma modalidade importante no controle das DTMs. Por outro lado, apesar da dificuldade de confecção e obtenção das placas balanceadas, tal desenho poderia prover proteção extra a articulações comprometidas. Deve ficar claro que a presença de contatos no lado de não-trabalho não está indicada na 
finalização de reconstruções oclusais, por motivos dento-periodontais óbvios.

Ainda, conclue-se que a evolução dessas patologias da ATM parece não ser tão agressiva, devido à melhora (apesar de mais lenta e não significante) também do grupo placebo.

Trabalhos com metodologia direta de observações de cargas articulares e imagens da ATM devem constituir futuros trabalhos para elucidar qual a real relação entre essas variáveis. 
Conclusões 


\section{7 - CONCLUSÕES}

Baseado nos resultados, pôde-se concluir que:

a. O tipo de guia não influenciou o comportamento de redução da dor, porém ambas as placas oclusais foram superiores à não oclusiva em relação à escala de dor;

b. Reduções significativas da sensibilidade articular e muscular foram observadas para os três grupos;

c. A movimentação mandibular foi semelhante para toda a amostra;

d. A alteração dos ruídos articulares foi semelhante para os três grupos;

e. O relato do paciente para o conforto com a placa e ruído articular foi melhor para o grupo I (placa balanceada) e II (placa com guia pelo canino) e em relação à mudança de mordida não houve alteração para os três grupos avaliados. 
Referências Bibliográficas 


\section{REFERÊNCIAS BIBLIOGRÁFICAS}

1 AGERBERG, G.; SANDSTROM, R. Frequency of occlusal interferences: a clinical study in teenagers and group adults. J. prosth.. Dent., v.59, n.2, p.212-7, 1988.

2 AKOREN, A.C.; KARAAGACLIOGLU, L. Comparison of the electromiographic activity of individuals with canine guidance and group function occlusion. J. oral Rehab., v.22, p.73-7, 1995.

ALENCAR JÚNIOR, F.G.P. Avaliação do efeito placebo no tratamento de pacientes portadores de disfunção craniomandibular (DCM) através do uso de placas miorrelaxantes convencionais e placas não oclusais Bauru. 1994. 114p. Dissertação (Mestrado) - Faculdade de Odontologia de Bauru, Universidade de São Paulo.

ALEXANDER, P.C. The periodontium and the canine function theory. J. prosth. Dent., v.18, n.6, p.571-8, 1967. study of two treatment methods for internal derangement of the temporomandibular joint. J. prosth. Dent., v.53, n.3, p.392-7, 1985.

\footnotetext{
* Normas recomendadas para uso no âmbito da Universidade de São Paulo, com base no documento "Referências Bibliográficas: exemplos", emanados do Conselho Supervisor do Sistema Integrado de Bibliotecas da USP, em reunião de 20 de setembro de 1990.
} 
6 BABA, K. et al. Influence of experimental occlusal discrepancy on masticatory muscle activity during clencking. J. oral Rehab., v.23, p.55-60, 1996.

$7 \quad$ BABA, K. et al. Impact of balancing-side tooth contact on clenching induced mandibular displacements in humans. J. oral Rehab., v.28, p.721-27, 2001.

8

BAKKE, M.; MICHLER, L. Temporalis and masseter muscle activity in patients with anterior open bite and craniomandibular disorders. Scand. J. dent. Res., v.99, p.219-28, 1991.

9 BAKKE, M.; MOLLER, E. Distortion of maximal elevator activity by unilateral premature tooth contact. J. dent. Res., v.80, p.67-75, 1980.

10 BALDIOCEDA, F.; PULLINGER, A.G.; BIBB, C.A. Relationship of condylar bone profiles and dental factor to articular soft-tissue thickness. J. craniomandibular dis. fac. oral pain, v.4, n.2, p.71-9, 1990.

11 BARBENEL, J.C. Analysis of forces at the temporomandibular joint: during function. Dent. Practit., v.19, n.9, p.305-10, 1969.

12 BARBENEL, J.C. The biomechanics of the temporomandibular joint: a theoretical study. J. Biomechanics, v.5, p.251-6, 1972.

13 BARBENEL, J.C. The mechanics of the temporomandibular joint - a theoretical and electromyographical study. J. oral Rehab., v.1, p.19-27, 1974. 
14 BECK, F.M. Placebos in dentistry: their profund potential effects. J. Amer. dent. Ass., v.95, p.1122-6, 1977.

15 BELSER, V.C.; HANNAN, A.G. The influence of altered working-side occlusal guidance on masticatory muscles and related joil movement. J. prosth. Dent., v.53, n.3, p.406-13, 1985.

16 BENSON, H. EPSTEIN, M.D. The placebo effect. J. Amer. Med. Ass., v.252, n.12, p.1225-7, 1975.

17 BREHNAN, K. et al. Direct measurement of boards at the temporomandibular joint in macaca arctoides. J. dent. Res., v.60, n.10, p.1820-4, 1981.

18 BORROMEO, G.L.; SUVINEN, T.I.; READE, P.C. A comparison of the effects of group function and canine guidance interocclusal device on masseter muscle electromiographic activity in normal subjects. J. prosth. Dent., v.74, n.2, p.174-80, Aug. 1995.

19 BOUVIER, M. Effects of age on the ability of the rat temporomandibular joint to respond to changing functional demands J. dent. Res., v.67, n.9, p.1206-12, 1988.

20 BOUVIER, M.; HYLANDER, W.L. The effect of dietary consistency on gross and histologic morphology in the craniofacial region of young rats. Amer. J. Anat., v.170, p.117-26, 1984.

21 BOUVIER, M.; ZIMNG, M.L. Effects of mechanical boards on surface morphology of condylar cartilage of the mandible in rats. Acta Anat., v.129, p.293-300, 1987. 
22 BOYD, R.L. et al. Temporomandibular joint forces measured at the condyle of macaca arctoides. Amer. J. Orthodont. Dentofac. Orthop., v.97, n.6, p.472-79, 1990.

23 BRODERSON, S.P. Anterior guidance - the key to successful occlusal treatment. J. prosth. Dent., v.39, n.4, p.???, 1978.

24 BUCHNER, R. et al. Electromyographic parameters related to clenching level and jaw-jerk reflex in patients with a simple type of myogenous cranio-mandibular disorder. J. oral Rehab., v.19, p.495-511, 1992.

25 BUTLER, J.H.; FOLKE, L.E.; BANDT, C.L. A descriptive survey of signs and symptoms associated with the myofascial paindysfunction syndrome. J. Amer. dent. Ass., v.90, n.??, p.635-9, 1975

26 CANAY, S. et al. Effects of muscle relaxation splint therapy on electromiographic activities of masseter and anterior temporalies muscles. Oral Surg., v.85, p.674-79, 1998.

27 CAPP, N.J. Occlusion and splint therapy. Brit. dent. J., v.186, n.5, p.217-22, 1999.

28 CARRARO, J.J.; CAFFESSE, R.G. Effect of occlusal splints on TMJ symptomatology. J. prosth. Dent., v.40, n.3, p.563-6, 1978.

29 CASWELL, C.W. Treatment of anterior displaced meniscus with a flat occlusal splint. J. dent. Res., v.63, p.172, 1984. 

n.1, p.111-23, 1990.

31 CHEN, J.; XU, L. A finite element analysis of the human temporomandibular joint. J. Biomechanical Eng., v.116, p.401-7, 1994.

CHONG-SHAN, S.; HUI-GUN, W. Postural and maximum activity in elevators during mandible pre and post-occlusal splint treatment of temporomandibular joint disturbance syndrome. J. oral Rehab., v.16, p.155-61, 1989.

33 CHRISTENSEN, L.V. Physiology and pathophysiology of skeletal muscle contractions. J. oral Rehab., v.13, p.451-61, 1986.

34 CHU, S.A. et al. The effect of interocclusal appliances on temporomandibular joints as assessed by $3 \mathrm{D}$ reconstruction of MRI scans. Aust. dent. J., v.46, n.1, p.18-230, 2001.

CLARK, G.T. A critical evaluation of orthopedic interocclusal appliance therapy: design, theory and overall effectiveness. J. Amer. Dent. Ass., v.108, n.3, p.359-64, Mar. 1984. CLARK, G.T.; BEEMSTERBOER, P.L.; JACOBSON, R. The effect of sustained submaximal clenching on maximum bite force in myofascial pain dysfuction patients. J. prosth. Dent., v.82, n.6, p.704-13, 1997. 
37 CLARK, G.T. et al. Nocturnal electromyographic evaluation of myofascial pain dysfunction in patients undergoing occlusal splint therapy. J. Amer. dent. Ass., v.99, p.607-11, 1979.

38 CLARK, G.T. et al. Sixty-eight years of experimental occlusal interference studies: what have we learned. J. oral Rehab., v.11, p.387-91, 1984 .

CONTI, P.C.R. et al. A cross-sectional study of prevalence and etiology of signs and symptoms of temporomandibular disorders in high school ans university students. J. Orofac. pain, v.10, n.3, p.254-62, Summer 1996.

DAHLSTROM, L. et al. Comparison of effects of electromyographic biofeedback and occlusal splint therapy on mandibular dysfunction. Scand. J. dent. Res., v.90, p.151-6, 1982.

41 D'AMICO, A. The canine teeth-normal functional relation of the natural teeth of man. J. South Calif. dent. Ass., v.26, n.6, p.6-23, 49-60, 127-42, 175-82, 194-208, 239-41, 1958.

42 DAO, T.T.; LAVIGNE, G.J. Oral splints: the crutches for temporomandibular disorders and bruxism? Crit. Rev. oral biol. Med., v.9, n.3, p.345-61, 1998.

43 DAO, T.T. et al. The efficacy of oral splints in the treatment of myofascial pain of the jaw muscles: a controlled clinical trial. Pain, v.56, p.85-94, 1994. 
44 DAVIES, S.J.; GRAY, R.J.M. The pattern of splint usage on the management of two common temporomandibular disorders. Part II: the stabilisation splint in the treatment of pain dysfunction syndrome. Brit. dent. J., v,183, n.7, p.247-51, 1997.

45 DONEGAN, S.J.; CHRISTENSEN, L.V.; MCKAY, D.C. Canine tooth guidance and temporomandibular joint sounds in non-patients and patients. J. oral Rehab., v.23, p.799-804, 1996.

46 DRAGO. C.J.; HUGH, J.D.; BARGHI, N.J. Nightguard vertical thickness on nocturnal bruxism. J. dent. Res., v.58, p.317, 1999. Abstract n. 309.

47 DWORKIN, S.F. et al. Constant, remitted and cyclic pain patterns in TMD: three year follow-up. J. dent. Res., v.70, p.441, 1991. Abstract n. 1399.

EKBERG, E.; NILNER, M. The influence of stabilisation appliance therapy and other factors on the treatment outcome in patients with temporomandibular disorders of arthrogeneous origin. Swed. dent. J., v.23, p.39-47, 1999.

49 EKBERG, E.C.; VALLON, D.; NILNER, M. Occlusal appliance therapy in patients with temporomandibular disorders. A double-blind controlled study in a short-term perspective. Acta odont. Scand., v.56, p.122-8, 1998. 
50 ERHARDSON, S. et al. Vertical forces developed by the jaw elevator muscles during unilateral maximal clenching and their distribution on teeth and endyles. Swed. Dent., v.17, p.23-34, 1993.

51 FAULKNER, M.G.; HATCHER, D.C.; HAY, A. A three-diomensional investigation of temporomandibular joint boarding. $\mathbf{J}$. Biomechanics, v.20, n.10, p.997-1002, 1987.

52 FERRARIO, V.F. et al. Temporomandibular joint dysfunction and flat lateral guidances: a clinical association. J. prosth. Dent., v.75, n.3, p.534-129 1996.

53 FITINS, D.; SHEIKHOLESLAM, A. Effect of canine guidance of maxillary occlusal splint on level of activation of masticatory muscles. Swed. Dent., v.17, n.6, p.235-41, 1993.

54 GAZIT, D. et al. Effect of occlusal stimulus on bone remodelling in rat mandibular condyle. J. oral Path., v.16, p.395-98, 1987.

55 GEAR, R.W. Controle neural do comportamento bucal e seu impacto sobre a oclusão. In.: MCNEILL, C. Ciência e prática da oclusão. São Paulo, Quintessence, 2000.

56 GIBBS, C.H. et al. Occlusal forces during chewing and swollowing as measured by sound transmission. J. prosth. Dent., v.46, n.4, p.???, 1981.

57 GLASS, E.G.; GLAROS, A.G.; MCGLYNN, F.D. Myofascial pain dysfunction: treatments used by ADA members. Cranio, v.11, n.1, p.25-9, 1993. 
58 GOHARIAN, R.K.; NEFF, P.A. Effect of occlusal retainess on temporomandibular joint and facial pain. J. prosth. Dent., v.44, n.2, p.206-8, Aaug. 1980.

GOLDBERG, J.S. Intrarticular pressure in the functioning human temporomandibular joint and its alteration by uniform elevation of the occlusal plane. J. Maxillofac. Surg., v.52, p.679-80, 1994. with myofascial pain-dysfunction syndrome to mock equilibration. J. Amer. dent. Ass., v.92, p.755-8, 1976.

61 GRAHAM, G.S.; RUGH, J.D. Effect of splint occlusal guidance on masticatory muscle EMG activity. J. dent. Res., v.63, p.172, 1984.

62 GRAHAM, G.S.; RUGH, J.D. Maxillary splint occlusal guidance patterns and electromyographic activity of the jaw-closing muscles. J. prosth. Dent., v.59, n.1, p.73-7, 1988.

63 GRAY, R.J.; DAVIES, S.J. Occlusal splints and temporomandibular disorders: why, when, how?. Dent. Update, v.28, p.194-9, 2001.

64 GRAY, R.J.; DAVIES, S.J.; QUAYLE, A.A. A clinical approach to temporomandibular disorders splint therapy. Brit. dent. J., v.20, p.135-42, 1991.

65 GRAY, R.J.; DAVIES, S.J.; QUAYLE, A.A. A comparison of two splints in the treatment of TMJ pain dysfunction syndrome. Can 
occlusal analysis be used to predict success of splint therapy? Brit. dent. J., v.20, n.55, p.55-8, 1991. dysfunction (MPD) syndrome: a comparative study. J. Amer. dent. Ass., v.84, p.624-8, 1972.

67 GREENE, C.S.; LASKIN, D.M. Long-term evaluation of treatment for myofascial pain-dysfunction syndrome: a: a comparative study. J. Amer. dent. Ass., v.107, p.235-8, 1983.

68 GRUBWIESER, G. et al. Quantitative analysis of masseter and temporalis EMGs: a comparison of anterior guided versus balanced occlusal concepts in patients wearing complete dentures. J. oral Rehab., v.26, p.731-6, 1999.

69 GRUNET, I. et al. Masseter and temporals surface electromyographic in patients wearing complete dentures comparing anterior and posterior occlusal concepts - a pilot study. J. oral Rehab., v.21, p.337-47, 1994

70 HARKINS, S. et al. Administration of clonazepan in the treatment of TMD and associated myofascial pain: a double-blind pilot study. J. craniomandibular. dis. fac. oral pain, v.5, n.3, p.179-86, 1991.

71 HART, R.T. et al. Modeling the biomechanics of the mandible: a three-dimensional finite element study. J. Biomechanics, v.25, n.3, p.261-86, 1992. 
72 HATCHER, D.C.; FAULKNER, M.G.; HAY, A. Development of mechanical and mathematic models to study temporomandibular joint boarding. J. prosth. Dent., v.55, n.3, p.377-84, 1986.

73 HEKNEBY, M. The boad of the temporomandibular joint: physical calculations and analyses. J. prosth. Dent., v.31, n.3, p.303-12, 1974.

74 HELKIMO, E; CARLSSON, G.E.; HELKIMO, M. Bite force and state of dentition. Acta odont. Scand., v.35, n.6, p.297-303, 1977.

75 HOLMGREN, K.; SHEIKHOLESLAM, A.; RIISE, C. Effect of a fullarch maxillary occlusal splint on parafunctional activity during sleep in patients with nocturnal bruxism and signs and symptoms of craniomandibular disorderes. J. prosth. Dent., v.69, n.3, p.293-7, 1993.

76 HOLMGREN, K. et al. The effects of na occlusal splint on the electromyographic activities of the temporal and masseter muscles during maximal clenching in patients with a habit of nocturnal bruxism and signs and symptoms of craniomandibular disorderes. J. oral Rehab., v.17, p.447-59, 1990.

77 HUMSI, A.N.; et al. The immediate effects of a stabilization splint on the muscular symmetry in the masseter and anterior temporal muscles of patients with a craniomandibular disorder. J. prosth. Dent., v.62, n.3, p.339-43, Sept. 1989. 
HOLMLUND, A.; AXELSSON, S. Temporomandibular joint ostearthrosis. Correlation of clinical and arthroscopic findings with degree of molar support. Acta odont. Scand., v.52, p.214-8, 1994.

79 HOUSE, M.M. Studies in prosthesis. J. Amer. dent. Ass., v.18, p.827-52, 1931.

80 ISRAEL, H.A. Current concepts in the surgical management of temporomandibular joint disorders. J. oral Maxillofac. Surg., v.52, p.289-94, 1994.

81 ITO, T. et al. Loading on the temporomandibular joints with five occlusal conditions. J. prosth. Dent., v.5, n.4, p.478-84, 1986.

82 JENSEN, W.O. Effects of comparative jaw size on mandibular movement and occlusion. J. prosth. Dent., v.64, n.2, p.174-9, Aug. 1990.

$83 \mathrm{KAHN}$, A.E. The importance of canine and anterior tooth positions in occlusion. J. prosth. Dent., v.37, n.4, p.397-409, 1977.

84 KAHAN, J. Prevalence of dental occlusal variables and intra-articular temporomandibular disorders: molar relationship, lateral guidance and nonworking side contacts. J. prosth. Dent., v.82, n.4, p.4105, 1999.

85 KATONA, T.R. The effects of cusp and jaw morphology on the forces on teeth and the temporomandibular joint. J. oral Rehab., v.16, p.211-9, 1989. 
86 KIMMEL, S.S. Temporomandibular disorders and occlusion: an appliance to treat occlusion generated symptoms of TMD in patients presenting with deficient anterior guidance. Cranio, v.12, n.4, p.234-40, 1994.

87 KOOLSTRA, J.H. et al. A three dimensional mathematical model of the human masticatory system prediciting maximum possible bite forces. J. Biomechanics, v.21, n.7, p.563-76, 1988.

88 KORIOTH, T.W.P. Física simulada da mandíbula humana. In.: MCNEILL, C. Ciência e prática da oclusão. São Paulo, Quintessence, 2000.

KORIOTH, T.W.P. et al. Digital assessment of occlusal wear patterns on occlusal stabilization splints: a pilot study. J. prosth. Dent., v.80, n.2, p.209-13, 1998.

90 KREINER, H.; BETANCOR, E.; CLARK, G.T. Occlusal stabilization appliances. Evidence of their efficacy. J. Amer. dent. Ass., v.132, p.770-7, June 2001.

$91 \mathrm{KUBOKI}, \mathrm{T}$. et al. The effect of occlusal appliances and clenching on the temporomandibular joint space. J. Orofac. Pain., v.11, n.1, p.67-77, 1997.

92 KURITA, H.; IKEDA, K.; KURASHINA, K. Evaluation of the effect of a stabilization splint on occlusal force in patients with masticatory muscle disorders. J. oral Rehab., v.27, n.1, p.79-82, Jan. 2000. 
93 KURITA, H.; KURASHINA, K.; KOTANI, A. Clinical effect of full coverage occlusal splint therapy for specific temporomandibular disorder conditions and symptoms. J. prosth. Dent., v.78, n.5, p.506-10, Nov.1997.

94 LASKIN, D.M.; GREENE, C.S. Influence of the doctor-patient: relationship on placebo therapy for patients with myofascial paindysfunction (MPD) syndrome. J. Amer. dent. Ass., v.85, p.892-4, 1972.

95 LEEUW, R. et al. Clinical signs of TMJ osteoarthrosis and internal derangement 30 years after nonsurgical treatment. J. Orofacial Pain, v.8, n.1, p.18-24, 1994.

96 LEEUW JUNIOR, J. et al. Assessment of treatment outcome in patients with craniomandibular dysfunction. J. oral Rehab., v.21, n.6, p.655-66, 1994.

97 LEIB, A.M. The occlusal bite splint - a noninvasive therapy for occlusal habits and temporomandibular disorders. Compedium, v.17, n.11, p.1081-90, 1996.

98 LIST, T. et al. Acupuncture and occlusal splint therapy in the treatment of craniomandibular disorders. Swed. Dent., v.16, p.125-41, 1992.

99 LOBBEZOO, F. et al. The effect of an occlusal stabilization splint and the mode of visual feedback on the activity balance between jaw- 
elevator muscles during isometric contraction. J. dent. Res., v.72, n.5, p.876-82, 1993.

100 LONG, J.H. Location centric relation with leal-gauge. J. prosth. Dent., v.29, n.6, p.608-10, 1973.

101 LOOS, L.G. Semiadjustable instrumentation based on "anterior" guidance. J. prosth. Dent., v.45, n.5, p.521-4, ???.

102 LOUS, I. Treatment of TMJ syndrome by pivots. J. prosth. Dent., v.40, n.3, p.179-82, 1987.

103 LUNDH, H.J.; KOPP, S. Anterior repositioning splint in the treatment of temporomandibular joint with reciprocal clicking: comparison with a flat occlusal splint and an untreated control group. Oral Surg., v.60, p.131-6, 1985.

104 LUNDH, H.J.; SANDER, S. Disk-repositioning onlays in the treatment of temporomandibular joint disk displacement: comparison with a flat occlusal splint and with no treatment. Oral Surg., v.66, n.11, p.155-62, 1988.

105 LYDIATT, D.D.; DAVIS, L.F. The effects of immobilization on the reabilit temporomandibular joint. J. oral Maxillofac. Surg., v.43, p.188-93, 1985.

106 MACDONALD, J.W.C.; HANNAM, A.G. Relationship between occlusal contacts and jaw-closing muscle activity durting tooth clenching: Part I. J. prosth. Dent., v.52, n.5, p.718-29, 1984. 
107 MAGNUSSON, T.; LIST, T.; HELKIMO, M.J. Self assessment of pain and discomfort in patients with temporomandibular disorders: a comparison of five differents scales with respect to their precision and sensitivity as well as their capacity to register memory of pain and discomfort. J. oral Rehab., v.22, n.8, p.549-56, 1995.

$108 \mathrm{MAH}$, R.T. et al. Princípios de engenharia e estratégias para a confecção de modelos. Ciência e prática da oclusão. São Paulo, Quintessence, 2000.

109 MAJOR, P.W.; NEBBE, B. Use and effectiveness of splint appliance therapy: review of literature. J. craniomandibular. Pract., v.15, n.2, p.159-66, 1997.

110 MANNS, A.; CHAN, C.; MIRALLES, R. Influence of group function and canine guidance on electromyographic activity of elevator muscles. J. prosth. Dent., v.57, n.4, p.494-501, Apr. 1987.

111 MANNS, A.; MIRALLES, R.; GUERRERO, F. The changes in electrical activity of postural muscles of the mandible upon varying the vertical dimension. J. prosth. Dent., v.45, n.4, p.438-45, 1981.

112 MANNS, A. et al. The immediate effect of the variation of anteroposterior laterotrusive contacts on the elevator EMG activity. Cranio, v.11, n.9, p.184-91, 1993.

113 MANNS, A. et al. Influence of vertical dimension in the treatment of myofascial pain-dysfunction syndrome. J. prosth. Dent., v.50, n.5, p.700-9, 1983 
114 MANSOUR, R.M.; REYNIK, R.J. In vivo occlusal forces and moments: I. forces measured in terminal hinge position and associated moments. J. dent. Res., v.54, n.1, p.114-20, 1975.

115 MARKLUND, S.; WANMAN, A. A century of controversy regarding the benefit or detriment of occlusal contacts on the mediotrusive side. J. oral Rehab., v.27, n.7, p.533-62, 2000.

116 MCADAM, D.B. Tooth boarding and cuspal guidance in canine and group-function occlusions. J. prosth. Dent., v.35, n.3, p.283-90, 1976.

117 MCNAMARA, J.A.; CARLSON, D.S. Quantitative analysis of temporomandibular joint adaptations to protrusive function. Amer. J. Orthodont., v.76, n.6, p.593-611.

118 MCNEILL, C. Management of temporomandibular disorders: concepts and controversies. J. prosth. Dent., v.77, n.5, p.510-22, 1997.

119 MINAGI, S. et al. The relationship between balancing - side occlusal contact patterns and temporomandibular joint sounds in humans: proposition of the concept of balancing-side protection. $\mathbf{J}$. craniomandibular dis. fac. oral pain, v.4, n.4, p.251-6, 1990.

120 MIRALLES, R.; MANNS, A.E.; PASINI, C. Influence of different centric functions on electromyographic activity of elevator muscles. J. craniomandibular Pract., v.6, n.1, p.26-33, 1988. 
121 MIRALLES, R. et al. Influence of balanced occlusion and canine guidance on electromyographic activity of elevator muscles in complete wearers. J. prosth. Dent., v.61, n.4, p.494-8, 1989

122 MIRANDA, J.E.S. Avaliação longitudinal da efetividade das placas oclusais reposicionadoras no controle de patologias da ATM: comparação com placas oclusais estabilizadoras em grupo controle. Bauru. 2000. Tese (Doutorado). - Faculdade de Odontologia de Bauru, Universidade de São Paulo.

123 MOLIN, C. Vertical isometric muscle forces of the mandible. A comparative study of subjects with and without manifest temporomandibular pain dysfunction syndrome. Acta Odont. Scand., v.30, p.485-99, 1972.

124 MONGINI, F. Anatomic and clinical evaluation of the relationship between the temporomandibular joint and occlusion. J. prosth. Dent., v.38, n.5, p.539-51, 1977.

125 MONGINI, F. Influence of function on temporomandibular joint remodeling and degenerative desease. Dent. Clin. N. Amer., v.27, n.3, p.479-94, 1983.

126 MONGINI, F.; CALDERALE, P.M.; BARBERI, G. Relationship between structure and the stress pattern in the human mandible. J. dent. Res., v.58, p.2334-7, 1979. 
127 MONTGOMERY, M.T.; RUGH, J.D.; THRASH, W.J. Effect of canine guidance splints on daytime masticatory muscle activity. J. dent. Res., v.65, p.180, 1986.

128 NELSON, S.J. Principles of stabilization bite splint therapy. Dent. Clin. N. Amer., v.39, n.2, p.403-21, Apr. 1995.

129 NELSON, S.J.; HANNAM, A.G. A biomechanical simulation of the craniomandibular apparatus during tooth-clenching. J. dent. Res., v.61, p.211, 1982.

130 NITZAN, D.W. Intraarticular pressure in the functioning human temporomandibular joint and its alteration by uniform elevation of the occlusal plane. J. oral Maxillofac. Surg., v.52, n.7, p.671-9, July 1994 .

131 OGAWA, T.; OGIMOTO, T.; KOYANO, K. Pattern of occlusal contacts in lateral positions: canine protection and group function validity in classifying guidance patterns. J. prosth. Dent., v.80, n.1, p.6774, July 1998.

132 OKESON, J.P. Fundamentos da oclusão e desordens temporomandibulares. 2.ed., São Paulo, Artes Médicas, 1992.

133 OKESON, J.P.; KEMPER, J.T.; MOODY, P.M. A study of the use of occlusion splints in the treatment of acute and chronic patients with craniomandibular disorders. J. prosth. Dent., v.48, n.6, p.708-12, 1980. 
134 OKESON, J.P. et al. Evaluation of occlusal splint therapy and relaxation procedures in patients with temporomandibular disorders. J. Amer. dent. Ass., v.107, p.420-4, 1983.

135 O'LEARY, T.J.; DRAKE, R.B. Tooth mobility in cuspid-protected and group-function occlusions. J. prosth. Dent., v.27, n.1, p.21-5, 1972.

136 OSBORN, J.W.; BARAGAR, F.A. Predicted pattern of human muscle activity during clenching from a computer assited model: simmetric vertical bite forces. J. Biomechanics, v.18, n.8, p.599-612, 1985.

137 PAESANI, D.A. et al. Evaluation of the reproducibility of rest activity of the anterior temporal and masseter muscles in asymptomatic and symptomatic temporomandibular subjects. J. oralfacial Pain, v.8, p.402-6, 1994.

138 PALLA, S.; ANTONNI, C. Short-term treatment, outcome of TMJ clicking. Society Oral Physiology, v.??, p.560.

139 PERTES, R.A.; GROSS, S.C. Clinical management of temporomandibular disorders and orofacial pain. Chicago, Quintessence, 1995. 368p.

140 PETROVIC, A.; STUTZMANN, J. Effect on the rat mandible of a chincup-type appliance and of partial or complete immobilization. Proc. Finn. Dent. Soc., v.87, n.1, p.85-91, 1991. 
141 PICHSLINGER, E. et al. The effect of occlusal splint therapy on different curve parameters of axiographic TMJ tracings. $\mathbf{J}$. Craniomandibular Pract., v.13, n.1, p.35-41, 1995.

142 POSSELT, U.; WOLFF, I. Treatment of bruxism by bite guards and bite plates. J. Canad. dent. Ass., v.29, p.773, 1963.

143 PRUIM, G.J.; JONGH, H.J.; BOSCH, J.T. Forces acting on the mandible during bilateral static bite at diferent bite force levels. J. Biomechanics, v.13, p.755-63, 1980.

144 RADIN, E.L. et al. Response of joints to impact loading. Arthrits Rheum.., v.14, n.3, p.356-62, 1971.

145 ROBERTS, C.A.; TALLENTS, R.H.; HANDELMAN, S.L. Correlation of clinical parameters to the arthrographic depiction of temporomandibular joint internal derangements. Oral Surg., v.66, n.1, p.32-6, 1988.

146 RUBINOFF, M.S.; GROSS, A.; MCCALL JUNIOR, W.D. Conventional and non-occluding splint therapy compared for patients with myofascial pain dysfunction syndrome. Gen. Dent., v.35, p.502-6, 1987.

147 ROBINSON, M. The temporomandibular joint: theory of reflex controlled nonlever action of the mandible. J. Amer. dent. Ass., v.33, p.1260-71, 1946. 
148 RUGH, J.D.; HARLAN, J. Nocturnal bruxism and temporomandibular disorders. In.: JANKOVIC, J.; TOLUSA, E. Facial dyskinesias. New York, Raven Press, 1988. p.328-41.

149 RUGH, J.D. et al. Effect of splint occlusal guidance patterns on nocturnal bruxism in MPD patients. J. prosth. Dent., v.66, p.193, 1987.

150 RUGH, J.D. et al. Effects of canine versus molar occlusal splint guidance on nocturnal bruxism and craniomandibular symptomatology. J. craniomandibular dis., v.3, n.4, p.203-10, Fall 1989.

151 SANTACATTERINA, A. et al. Review: a comparison between horizontal splint and repositioning splint in the treatment of disc dislocation with reduction. Literature meta-analysis. J. oral Rehab., v.25, p.81-8, 1998.

152 SANTOS, C.N. Avaliação da reproducibilidade interexaminadores na palpação muscular, após um programa de calibração. Bauru. 2000, Dissertação (Mestrado) - Faculdade de Odontologia de Bauru, Universidade de São Paulo

153 SANTOS JUNIOR, J.; NOWLIN, T.P. The effect of splint therapy on TMJ position measured by the Gerber resiliency test. J. oral Rehab., v.19, p.663-70, 1992. 
154 SATO, S.; MOTEGI, K. Management of nonreducing temporomandibular joint disk displacement. Evaluation of three treatments. Oral Surg., v.80, n.4, p.384-8, 1995.

155 SCAIFE JUNIOR, R.R.; HOLT, J.E. Natural occurrence of cuspid guidance. J. prosth. Dent., v.22, p.225-9, 1969.

156 SCHAERER, P.; STALLARD, R.E.; ZANDER, H.A. Occlusal interferences and mastication: an electromyographix study. J. prosth. Dent., v.17, n.5, p.438-49, 1967.

157 SCHUYLER, C.H. Fundamental principles in the correction of occlusal disharmony, natural and artificial. J. Amer. dent. Assoc., v.22, p.1193-202, 1935.

158 SCHUYLER, C.H. The function and importance of incisal guidance in oral rehabilitation. J. prosth. Dent., v.13, p.1011-29, 1963.

159 SCHWEIKERT, E.O. Anterior guidance. Quintessence International, v.18, n.4, p.253-60, 1987.

160 SELIGMAN, D.A.; PULLINGER, A.G. The degree to which dental attrition in modern society is a function of age and of canine contact. J. Orofac. Pain, v.9, n.3, p.266-75, Summer 1995.

161 SHAN, S.C.; YUN, W.H. Influence of an occlusal splint on integrated electromypgraphy of the masseter muscles. J. oral Rehab., v.18, p.257-64, 1991.

162 SHEIKHOLESLAM, A.; RIISE, C. Influence of experimental interfering occlusal contacts on the activity of the anterior temporal and 
masseter muscles during submaximal and maximal bite in the intercuspal position. J. oral Rehab., v.10, p.207-14, Jan. 1983. electromyographic study of the long-term effects of an occlusal splint on the temporal and masseter muscles in patients with functional disorders and nocturnal bruxism. J. oral Rehab., v.13, p.137-45, 1986.

164 SHUPE, R.J. et al. Effect of occlusal guidance on jaw muscle activity. J. prosth. Dent., v.51, n.6, p.811-8, 1984.

165 SIEBERT, G. Recent results concerning physiological tooth movement and anterior guidance. J. oral Rehab., v.8, p.479-93, 1981.

166 SIMMONS, H.C.; GIBBS, J. Recapture of temporomandibular joint disks using anterior repositioning appliances: an MRI study. J. craniomandibular. Pract., v.13, n.4, p.227-37, 1995.

167 SINDELAR, B.J.; EDWARDS, S.; HERRING, S.W. Morphologic changes in the TMJ following splint wear. Anat. Rec., v.266, p.167-76, 2002.

168 SINDELAR, B.J. et al. Effects of intraoral splint wear on proteoglycans in the temporomandibular joint disc. Arch. Biomechen. Biophys., v.377, n.1, p.64-70, 2000. 
169 SMITH, D.M.; MCLACHLAN, K.R.; MCCALL JUNIOR, W.D. A numerical model of temporomandibular joint boarding. J. dent. Res., v.65, n.8, p.1046-52, 1986.

170 SPEAR, F.M. Considerações fundamentais sobre o tratamento oclusal. In.: MCNELL, C. Ciência e prática da oclusão. São Paulo, Quintessence, 2000.

171 STOHLER, C.S. Aparelhos (placas) interoclusais. Eles oferecem vantagem biológica. In.: MCNEILL, C. Ciência e prática da oclusão. São Paulo, Quintessence, 2000.

172 STOHLER, C.S. Tomada de decisão clínica na oclusão: uma mudança no paradigma. In.: MCNEILL, C. Ciência e prática da oclusão. São Paulo, Quintessence, 2000.

173 STOREY, A.T. How to carry out temporomandibular disorders research in a clinical practice. In.: FRICTON, J.R.; DUBNER, R.B. Orofacial pain and temporomandibular disorders. New York, Raven Press, 1995.

174 STUART, C.E.; STALLARD, H. Principles involved in restoring occlusion to natural teeth. J. prosth. Dent., v.10, p.304, 1960.

175 THORNTON, L.J. Anterior guidance: group function/canine guidance. A literature review. J. prosth. Dent., v.64, n.4, p.479-82, 1990.

176 THROCKMORTON, G.S. Quantitative calculations of temporomandibular joint reaction forces. II The importance of the 
direction of the jaw muscle forces. J. Biomechanics, v.18, n.6, p.453-61, 1985.

177 TSUGA, K. et al. A short-term evaluation of the effectiveness of stabilization-type occlusal splint therapy for specific symptoms of temporomandibular joint dysfunction syndrome. J. prosth. Dent., v.61, n.5, p.610-13, 1989.

178 TURK, D.C.; ZAKI, H.S.; RUDY, T.E. Effects of intraoral appliance and biofeedback/stress management alone and in combination in treating pain and depression in patients with temporomandibular disorders. J. prosth. Dent., v.70, n.2, p.158-64, 1993.

179 VISSER, A.; NAEIJE, M.; HANSSON, T.L. The temporal/masseter cocontraction: an electromyographic and clinical evaluation of shortterm stabilization splint therapy in myiogenous CMD patients. J. oral Rehab., v.22, p.387-9, 1995.

180 VISSER, A. et al. Masticatory electromyographic activity in healthy young adults and myiogenous craniomandibular disorder patients. J. oral Rehab., v.21, p.67-76, 1994.

181 WEINBERG, L.A. Temporomandibular joint function and its effect on concepts of occlusion. J. prosthet. Dent., v.35, n.5, p.553-65, 1976.

182 WIDMALM, S.E. Use and abuse of bite splints. Comp. Continuing Educ. Dent., v.20, n.3, p.249-59, 1999. 
183 WILKINSON, T. et al. A comparison of the success of 24 hour occlusal splint therapy versus nocturnal occlusal splint therapy in reducing craniomandibular disorders. J. craniomandibular. Disord. Facial Oral Pain, v.6, p.64-70, 1992.

184 WILLIAMS, W.N. et al. The effect of periodontal bone loss on bite force discrimination. J. periodontol., v.58, n.4, p.236-9, 1987.

185 WILLIS, W.A. The effectiveness of an extreme canine-protected splint with limited lateral movement in treatment of temporomandibular dysfunction. Am. J. Orthodontics Dentofac. Orthopedics., v.107, n.3, p.229-34, 1995.

186 WILLIAMSON, E.H.; LUDQUIST, D.O. Anterior guidance: its effect on electromyographic activity of the temporal and masseter muscles. J. prosthet. Dent., v.49, n.6, p.816-23, 1983.

187 WILLIAMSON, E.H.; NAVARRO, Z.; ZWEMER, J.D. A comparison of electromyographic activity between anterior repositioning splint therapy and a centric relation splint. J. craniomandibular Pract., v.11, n.3, p.178-83, 1993.

188 WISKOTT, A.H.W.; BELSER, C. A rationale for a simplified occlusal design in restorative dentistry: historical review and clinical guidelines. J. prosth. Dent., v.73, n.2, p.169-83, 1995.

189 WODA, A.; VIGNERON, P. KAY, D. Nonfunctional and functional occlusal contacts: a review of the literature. J. prosth. Dent., v.42, n.3, p.335-41, 1979. 
190 WOOD, W.W.; TOBIAS, D.L. EMG response to alteration of tooth contacts on occlusal splints during maximal clenching. J. prosth. Dent., v.51, n.3, p.394-96, 1984.

191 WRIGHT, E.; ANDERSON, G.; SCHULTE, J. A randomized clinical trial of intraoral soft splints and palliative treatment for masticatory muscle pain. J. orofac. Pain, v.9, n.2, p.192-9, 1995.

192 YAFFE, A.; EHRLICH, J. The functional range of tooth contact in lateral gliding movements. J. prosth. Dent., v.57, n.6, p.730-3, 1987.

193 YAP, A.U.J. Effects of stabilization appliances on nocturnal parafunctional activities in patients with and without signs of temporomandibular disorders. J. oral Rehab., v.25, n.1, p.64-8, Jan. 1998.

194 YATANI, H. et al. The long-term effect of occlusal therapy on selfadministred treatment outcomes of TMD. J. orofac. Pain, v.12, p.75-88, 1998. 
Abstract 


\begin{abstract}
EVALUATION OF THE EFFECTIVITY OF STABILIZATION SPLINTS WITH BILATERAL BALANCED GUIDANCE FOR THE CONTROL OF INTERNAL TMJ DERANGEMENTS
\end{abstract}

The aim of this study was to evaluate the effect of balanced splints with bilateral balanced guidance, canine guidance and nonoccluding splints. For that purpose, a study sample was employed comprising 57 individuals presenting with signs and symptoms of disc displacement with reduction and complaint of TMJ pain and tenderness to palpation of the TMJ at least at one side, who were randomly assigned to three groups: $1^{\text {st }}$ group: 19 individuals submitted to therapy with a modified splint, the design of which allowed simultaneous contact of part of the teeth on all parts of the splint during excursive movements. $2^{\text {nd }}$ group: 20 individuals submitted to therapy with a splint with canine guidance, which established disocclusion of all other teeth during excursive movements. $3^{\text {rd }}$ group (control group): 18 individuals who received a nonoccluding splint that did not interfere with the occlusion. The entire sample was followed for 6 months and submitted to evaluation by means of the visual analogue scale (VAS), palpation of the TMJ and jaw elevator muscles and analysis of the mandibular movements and joint 
sounds. An evaluation concerning the patient's report regarding the joint sounds, occlusal changes and comfort was also performed. The results demonstrated that the type of guidance did not influence the behavior as to pain reduction, yet both occlusion splints were better than the nonoccluding splint as to the pain scale. Besides, despite of the achievement of similar outcomes in relation to opening, left lateral movement, protrusive movement, TMJ pain to palpation and also pain to palpation of most muscles analyzed, there were statistically better outcomes for the splints with balanced guidance (group I) and the splints with canine guidance. Concerning the subject's reports for comfort with the splint and joint sound, there was a better association for groups I and II. On this basis, it was concluded that there is no difference between the balanced guidance and the canine guidance for the treatment of individuals with disc displacement with reduction. 
Apêndice 


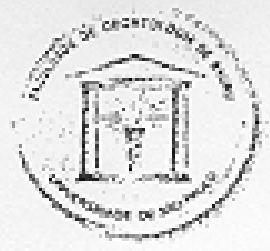

\section{Universidade de São Paulo Faculdade de Odontologia de Bauru}

Al. Dr. Octávio Pinhciro Brisolla, 9-75 - Bauru-SP - CEP 17012-901 - C.P. 73 PABX (0XX14)235-8000 - FAX (0XX14)223-4679

Comilê de Ética em Pesquisa

Processo $n^{\circ} 27 / 2002$

Bauru, 28 de junho de 2002

Senhor Professor,

Informamos que após o envio da documentação pendente, o projeto de pesquisa encaminhado a este Comitê denominado "Avaliação longitudinal de diferentes desenhos oclusais em placas oclusais no controle de patologias da ATM", de autoria de Carlos Neanes Santos, que será desenvolvido sob sua orientaçâo, foi APROVADO, nesta data

Comunicamos que após o envio do trabalho concluido, este Comitê enviará o parecer final, que será utilizado para a publicação do trabalho.

Atenciosamente,

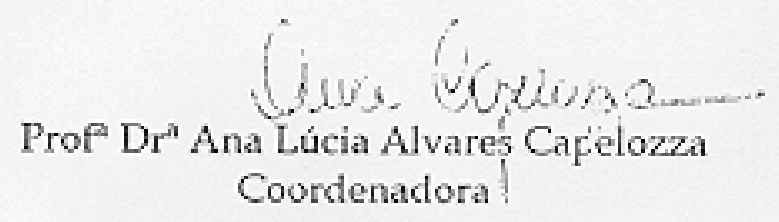

Ilm ${ }^{\circ}$ Sr. Prof. Dr. Paulo César Rodrigues Conti

DD. Docente do Departamento de Prótese 